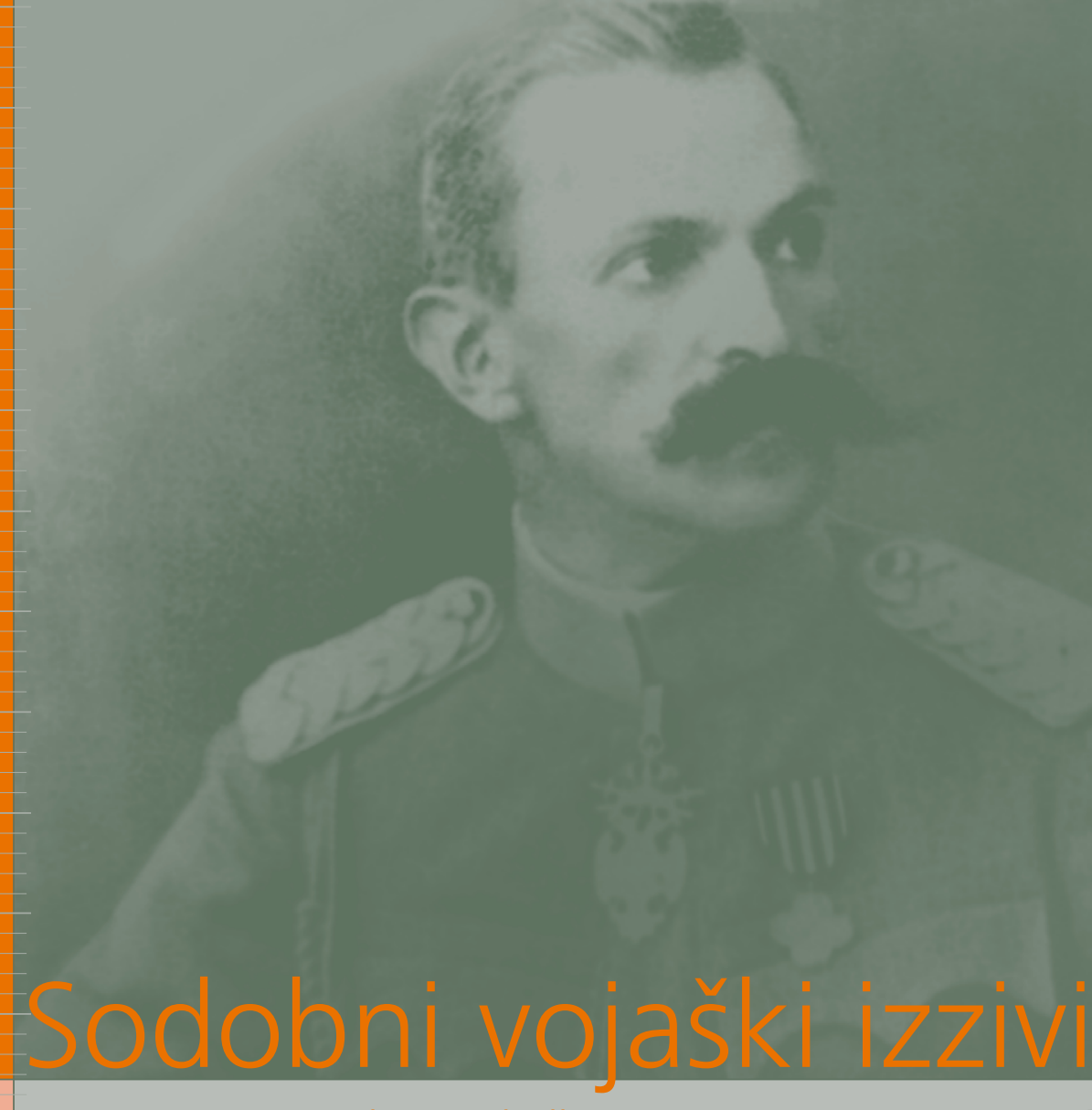

Contemporary Military Challenges

Znanstveno-strokovna publikacija Slovenske vojske

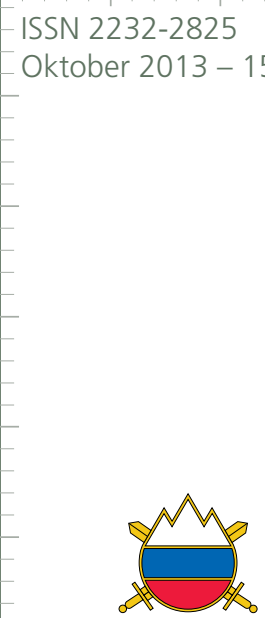

-REPUBLIKA SLOVENIJA

MINISTRSTVO ZA OBRAMBO

GENERALŠTAB SLOVENSKE VOJSKE 


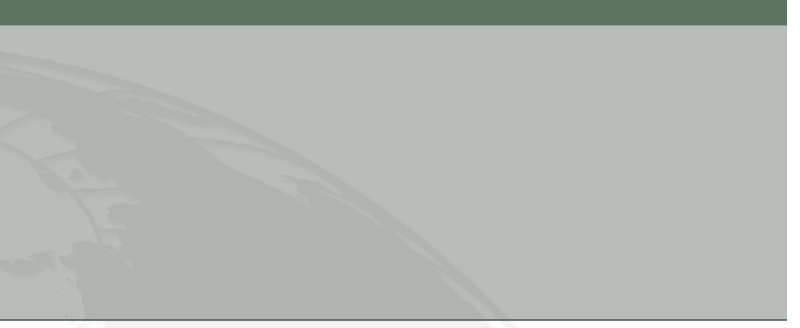

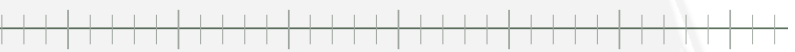




\section{Sodobni vojaški izzivi}

Contemporary Military Challenges

Znanstveno-strokovna publikacija Slovenske vojske

ISSN 2232-2825

UDK 355.5(479.4)(055)

Oktober 2013 - 15/št. 2

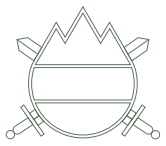

REPUBLIKA SLOVENIJA

MINISTRSTVO ZA OBRAMBO

GENERALŠTAB SLOVENSKE VOJSKE 
Izdajatelj

Publisher

Glavni urednik

Executive Editor

Odgovorni urednik

Managing Editor

Uredniški odbor

Editorial Board

Sekretar

Secretar

Uredniški svet

Editorial Council

Prevajanje

Translation

Lektoriranje

Proofreading

Oblikovanje

Design \& Graphic

Tisk

Print

Naklada

Edition

Revija je dostopna

na spletni strani

Publication web page

E-naslov urednice

Managing Editor

e-mail address
Generalštab Slovenske vojske

General Staff of Slovenian Armed Forces

brigadir dr. Andrej Osterman

dr. Liliana Brožič

VVU XIII. razreda dr. Valerija Bernik VVU XIV. razreda dr. Denis Čaleta polkovnik dr. Tomaž Kladnik dr. Igor Kotnik

VVU XV. razreda msgr. dr. Jože Plut podpolkovnik dr. Boris Rutar dr. Uroš Svete

višji vodnik Stefan Tomanović

dr. Andrej Anžič, dr. Anton Bebler dr. Sabine Collmer, dr. Damir Črnčec generalmajor Ladislav Lipič dr. Thomas Mockaitis generalpodpolkovnik dr. Iztok Podbregar dr. Tibor Szvircsev Tresh

Iris Žnidarič

Marjetka Brulec

Milena Sevšek Potočnik

Vesna Vrabič

Skupina Opus Design

Tiskarna Collegium graphicum, d. o. o.

$500 \mathrm{izvodov} /$ copies

http://www.slovenskavojska.si/publikacije/ sodobni-vojaski-izzivi/

http://www.slovenskavojska.si/en/publications/ contemporary-military-challenges/

liliana.brozic@mors.si

Prispevki, objavljeni v Sodobnih vojaških izzivih, niso uradno stališče Slovenske vojske niti organov, iz katerih so avtorji prispevkov.

Publikacija je uvrščena v bibliografsko zbirko podatkov COBISS.SI in PAIS International.

Articles, published in the Contemporary Military Challenges do not reflect the official viewpoint of the Slovenian Armed Forces nor the bodies in which the authors of articles are employed.

The publication is indexed in bibliography databases COBISS.SI and PAIS International. 


\section{ZAUPANJE IN OBOROŽENE SILE}

»Kadar zaupamo, je ocena visoka,

komunikacija pa preprosta, hitra in učinkovita."

Stephen R. Covey, 2004

\section{TRUST AND ARMED FORCES}

"When we trust the account is high,

communication is easy, instant, and effectiver

Stephen R. Covey, 2004 


\section{RECENZENTI/REFEREES}

Dr. Liliana Brožič

Dr. Damir Črnčec

Dr. Maja Garb

Simon Korez

Dr. Igor Kotnik

Dr. Boris Rutar

Dr. Vinko Vegič 


\section{VSEBINA}

CONTENTS

7

Liliana Brožič

UVODNIK

9

EDITORIAL

11

KOMPLEKSNOST OBRAMBNO-VOJAŠKEGA OKOLA NAREKUJE STRATEŠKO UPRAVLANJE ODNOSOV Z JAVNOSTMI

THE COMPLEXITY OF DEFENCE AND MILITARY ENVIRONMENT REQUIRES STRATEGIC PUBLIC RELATIONS MANAGEMENT

33

DRUŽBENA OMREŽJA KOT IZZIV KOMUNICIRANJA V SLOVENSKI VOJSKI SOCIAL NETWORKS AS A CHALLENGE OF COMMUNICATION IN THE SLOVENIAN ARMED FORCES

49

Liliana Brožič

EVALVACIJA ODNOSOV Z JAVNOSTMI V SLOVENSKI VOJSKI

EVALUATION OF SLOVENIAN ARMED FORCES PUBLIC AFFAIRS

69

Miran Barovič

VOJSKA Z VIDIKA TEMELNIH POJMOV SOCIALNE PSIHOLOGIJE

Uroš Rošker

MILITARY FROM THE POINT OF VIEW OF BASIC SOCIAL PSYCHOLOGY TERMS 
87

Petra Resman

PSIHOLOŠKO DELOVANJE - VOJAŠKO DELOVANJE ALI UPORABNA SOCIALNA PSIHOLOGIJA?

PSYCHOLOGICAL OPERATIONS - MILITARY OPERATIONS OR APPLICABLE SOCIAL PSYCHOLOGY?

\section{1}

Janja Vuga,

Katarina Rajh,

Gašper Kavšek,

Katja Cimermančič,

Rafaela Križman,

Urška Učakar

SOCIALNA, INSTITUCIONALNA IN ORGANIZACIJSKA PODPORA V POHLEPNIH INSTITUCIJAH: ZADOVOLSTVO SLOVENSKIH VOJAŠKIH DRUŽIN SOCIAL, INSTITUTIONAL AND ORGANISATIONAL SUPPORT IN GREEDY INSTITUTIONS: SATISFACTION OF SLOVENIAN MILITARY FAMILIES

\section{9}

Mateja Kopač,

Jelena Juvan,

Maja Garb

SINDROM ZALIVSKE VOJNE

GULF WAR SYNDROME

141

AVTORJI

AUTHORS

149

NAVODILA AVTORJEM ZA OBLIKOVANJE PRISPEVKOV

155

INSTRUCTIONS FOR THE AUTHORS OF PAPERS 


\section{UVODNIK}

Spoštovani bralke in bralci!

Pred vami je druga letošnja številka Sodobnih vojaških izzivov, ki je posvečena posameznikom v oboroženih silah in tistim, ki prihajamo v stik z njimi. V začetku leta smo stopili v petnajsto leto izhajanja in ena izmed želja uredniškega odbora je bila pripraviti nekaj vsebin o odnosih z javnostmi in o vojaški psihologiji. Želeli smo izvedeti kaj več o zaznavanju in delovanju posameznika v oboroženih silah kot člana skupine, o odnosih v vojaški skupini ter o delovanju vojaške skupine v domačem in mednarodnem varnostnem okolju. V množici tistih, ki prihajamo v stik z njimi, so člani njihovih družin, sodelavke in sodelavci, njihovi sosedje, sovaščani, predstavniki medijev in različnih ustanov, slovenska in mednarodna javnost ter prebivalci območij, na katerih so nastanjene mednarodne oborožene sile.

Na hitro lahko dobimo vtis, da gre za povsem običajno delovno sredino z notranjimi in zunanjimi aktivnostmi ter množico odnosov, ki pri tem nastajajo. Toda oborožene sile so drugačne od drugih organizacij in delovnih okolij. Tako ne preseneča, da se je »oče odnosov z javnostmi« Edward Luis Bernays v začetku prejšnjega stoletja kalil prav v kolektivu takratnega ameriškega predsednika Thomasa Woodrowa Wilsona, kjer je bil zadolžen za odnose z javnostmi v času, ko je v Evropi potekala prva svetovna vojna. Prizadevanja in aktivnosti ZDA je Bernays opredelil kot prinašanje demokracije v Evropo.

Med uglednimi avtorji na področju odnosov z javnostmi, vojaške sociologije in psihologije so se mnogi preizkušali in strokovno izpopolnili prav v vojaških vrstah ali pa v neposredni povezavi z njimi. Avtorji v tej številki se sklicujejo na njihovo znanje in izkušnje, dodajajo pa tudi svoje. 
V članku Kompleksnost obrambno-vojaškega okolja narekuje strateško upravljanje odnosov z javnostmi avtorica Nada Serajnik Sraka z nami deli svoje izkušnje, ki jih je pridobila, ko je bila zaposlena v Uradu Republike Slovenije za komuniciranje in je sodelovala pri komuniciranju pridruževanja naše države Evropski uniji in Natu.

Nina Raduha predstavlja izkušnje Slovenske vojske pri vzpostavitvi in organiziranju delovanja v socialnih omrežjih. V članku Družbena omrežja koz izziv komuniciranja $v$ Slovenski vojski predstavi tudi rezultate izvajanja komunikacijske strategije in jih primerja z izkušnjami drugih.

V članku Evalvacija odnosov z javnostmi v Slovenski vojski Liliana Brožič predstavlja štiri različne projekte, ki so bili izvedeni, da bi ovrednotili komuniciranje vojske na različnih vzorcih ter ugotovili, zakaj je zaupanje javnosti pomembno za Slovensko vojsko in kje so še priložnosti za v prihodnje.

Miran Barovič in Uroš Rošker v članku Vojska z vidika temeljnih pojmov socialne psihologije ponujata vpogled v bistvene značilnosti vojaških skupin, kaj so njihove najpomembnejše zakonitosti in po čem se ločijo od drugih skupin z vidika socialne psihologije.

Kontingent Slovenske vojske na Kosovu je študija primera, ki ga je uporabila Petra Resman v članku Psihološko delovanje/Vojaško delovanje ali uporabna socialna psihologija? Da bi razložila osnove psihološkega delovanja in predstavila njegovo uporabno vrednost, predstavi ključne pojme in ugotovitve ter pojasni nekatere terminološke nejasnosti.

Janja Vuga je pri pripravi članka Socialna, institucionalna in organizacijska podpora v pohlepnih institucijah: zadovoljstvo slovenskih vojaških družin k sodelovanju povabila študente, s katerimi je opravila anketo med partnerji pripadnic in pripadnikov Slovenske vojske, da bi izvedeli, kako doživljajo njihovo odsotnost v času udeležbe v mednarodnih operacijah in na misijah.

Mateja Kopač, Jelena Juvan in Maja Garb so pripravile članek Sindrom zalivske vojne. Kar nekaj časa je preteklo od zalivske vojne, vendar nekateri vojaki, ki so se je udeležili, še vedno čutijo posledice. Avtorice jih sistematično analizirajo in predstavijo. 


\section{EDITORIAL}

Dear readers,

You are looking at this year's second issue of Contemporary Military Challenges dedicated to individuals in the armed forces and those of us who come in contact with them. At the beginning of the year, we entered the fifteenth year of publication, and the Editorial Board's wish was to prepare some subjects on public relations and military psychology. We wanted to learn more about the perception and functioning of individuals in the armed forces as team members. We also wanted to learn about relations in military teams and about the functioning of military teams in domestic and international security environment. The group of those who come in contact with them includes their family members, colleagues, neighbours, villagers, representatives of the media and various institutions, Slovenian and international public, as well as residents of the areas where international armed forces are located.

In a swift glance, one may get an impression that this is a completely normal working environment with indoor and outdoor activities, and a multitude of relationships build within that. However, armed forces differ from other organizations and working environments. It is thus no surprise that, in the beginning of the previous century, "the father of public relations", Edward Luis Bernays, strengthened his skills in the team of the then U.S. President Thomas Woodrow Wilson, where he was responsible for public relations at a time when the First World War raged through Europe. Bernays defined U.S. efforts and activities as bringing democracy to Europe.

Many of the prominent authors in the field of public relations, military sociology and psychology, tested and perfected their professional skills in the military or in direct connection with them. The authors in this issue refer to the knowledge and experience of these authors, as well as add their own. 
In the article The complexity of defence and military environment requires strategic public relations management, the author Nada Serajnik Sraka shares her experience acquired during her employment in the Communication Office of the Government of the Republic of Slovenia and her participation in the communication activities surrounding Slovenia's accession to the European Union and NATO.

Nina Raduha presents the experience of the Slovenian Armed Forces regarding the establishment and organization of work in social networks. In her article Social networks as a challenge of communication in the Slovenian Armed Forces, she presents the results of the implemented communication strategy and compare them with the experiences of others.

In her article Evaluation of Slovenian Armed Forces public affairs Liliana Brožič presents four different projects carried out to evaluate communication activities of the armed forces in various patterns. Their results have shown why public confidence is important for the Slovenian Armed Forces and identified opportunities for the future.

Miran Barovič and Uroš Rošker wrote the article Military from the point of view of basic social psychology terms, where they provide an insight into the essential characteristics of military teams, their most important rules and what in terms of social psychology makes them different from other teams.

Slovenian contingent in Kosovo is a case study used by Petra Resman in her article Psychological operations - military operations or applicable social psychology? In order to explain the basics of psychological operations and present its practical value, the author introduces key concepts and findings and explains some terminological confusions.

Janja VUGA invited her students to participate in the preparation of the article Social, institutional and organisational support in greedy institutions: satisfaction of Slovenian military families. They carried out a survey among the partners of Slovenian Armed Forces members to find out how they perceive their absence during deployments in international operations and missions.

Mateja Kopač, Jelena Juvan and Maja Garb wrote the article Gulf War Syndrome. Quite some time has passed since the Gulf War; however, some of the war participants still suffer the consequences. The authors analyse and present them in a systematic manner. 


\title{
KOMPLEKSNOST OBRAMBNO-VOJAŠKEGA OKOLJA NAREKUJE STRATEŠKO UPRAVLJANJE ODNOSOV Z JAVNOSTMI
}

\author{
THE COMPLEXITY OF DEFENCE AND MILITARY \\ ENVIRONMENT REQUIRES STRATEGIC PUBLIC \\ RELATIONS MANAGEMENT
}

Povzetek Vojska spada med ustanove državnega pomena, ki morajo komunicirati s svojimi številnimi javnostmi. Vojaški odnosi z javnostmi so del neoperativne aktivnosti oboroženih sil, njihov namen je vzpostavljanje ali ohranjanje dobrih odnosov in ustvarjanje sprejemljive podobe $\mathrm{v}$ javnosti, kar je življenjskega pomena za vsako vojsko. Vojaški odnosi z javnostmi se ne razlikujejo veliko od odnosov z javnostmi v zasebnem sektorju; uporabljajo enake strateške pristope in enaka orodja, le izdelek je drugačen. Ker delujejo v okolju javnega sektorja, so pogosto predmet kritične presoje medijev ter strokovne in tudi laične javnosti. Zato se, tako kot drugod, tudi na področju vojaških odnosov z javnostmi pričakuje visoka stopnja etičnosti in profesionalnosti.

Komunikacijski primeri iz prakse državnih ustanov, pa tudi s področja obrambno-vojaške prakse odnosov z javnostmi so v strokovni literaturi redko predstavljeni, v Sloveniji jih skoraj ni najti. V prispevku je prvič predstavljen študijski primer komunikacijskega programa in referendumske kampanje v podporo včlanitvi Slovenije v Nato. Primer je zanimiv za bralce, ne le zaradi celovite predstavitve kampanje, kritik in vprašanj, ki jih je kampanja sprožila, temveč tudi zaradi izjemnih izkušenj, ki so jih komunikatorji pridobili. Pokaže pa tudi na zapletenost in zahtevnost sodobnih političnih in vojaških odnosov z javnostmi, kar utrjuje potrebo po dosledni uporabi strateških pristopov h komuniciranju.

Ključne Odnosi zjavnostmi, vojaški odnosi z javnostmi, komunikacijski program, referenbesede dumska kampanja, Slovenska vojska, Nato.

Abstract Armed forces rank among the institutions of national interest and as such have to communicate with its numerous publics. Military public relations form a part of the armed forces' non-operational activities, aimed at establishing or maintaining good relations with different stakeholders and creating an acceptable public image, which is vital to any army. Military public relations do not differ much from the public 
relations in the private sector. They both use the same strategic approaches and the same tools, but differ in the product. Since they operate in the public sector environment, they are often subject to critical judgement by the media, as well as of the professional and lay publics. It is thus expected that in military public affairs, the same as elsewhere, they demonstrate a high level of ethics and professionalism.

Examples of communication practice of national institutions as well as of the defence and military sector are rarely presented in the literature and can hardly be found in Slovenia. This paper presents a case study of communication programme and the referendum campaign led in support of Slovenia's accession to NATO. The case study is also interesting for the readers not only because of the comprehensive presentation of the campaign, criticism and questions raised by the campaign, but also due to the useful lessons learned by the communicators. Moreover, the case also points to the complexity and demanding nature of modern political and military public relations and thus reinforces the need for a consistent use of strategic approaches to communication.

Key words Public relations, military public relations, communication program, referendum campaign, Slovenian Armed Forces, NATO.

Uvod Ko demokratične države sprejemajo odločitve, ki imajo pomembne posledice za vso državo (na primer vključitev v nadnacionalne integracije), o odločitvi večinoma ne odločajo le politične in strokovne elite, temveč se o njih izrekajo tudi državljani. Odločitev Slovenije, da se po osamosvojitvi vključi v Evropsko unijo in Nato, je sprožila proces velikih in dolgotrajnih priprav številnih vladnih in državnih institucij, ki so vsaka za svoje področje delovanja in pristojnosti sprožile prilagajanje zakonodajnih, administrativnih, strokovnih in organizacijskih okvirov ter vodile pogajanja o pogojih vključitve in sodelovanja. Sestavni del teh procesov je bilo tudi redno in obsežno komuniciranje glavnih akterjev z javnostmi, da bi bile te obveščene o vseh dimenzijah odločitve in pripravah ter posledicah vključitve za državo in državljane.

V prispevku najprej predstavim vlogo in namene političnih odnosov z javnostmi, med katere spadajo tudi vojaški, njihove posebnosti ter področja delovanja, v nadaljevanju pa študijski primer informativno-ozaveščevalne komunikacijske kampanje v podporo vstopu Slovenije v Nato. V komunikacijskih dejavnostih so imeli odločujočo vsebinsko vlogo Ministrstvo za zunanje zadeve (MZZ), Stalna misija RS pri Natu in Ministrstvo za obrambo (MO) s Slovensko vojsko (SV). Komunikatorji in drugi odločevalci so v kampanji pridobili mnogo koristnih izkušenj, ki so pomembno vplivale na nadaljnji razvoj odnosov z javnostmi. Študijski primer ni zanimiv le zaradi celovite predstavitve kampanje, kritik in vprašanj, ki jih je kampanja sprožila, temveč tudi zaradi razgrnitve obsežnosti, zahtevnosti in zapletenosti političnih in vojaških odnosov z javnostmi, kar utrjuje potrebo po strateškem načrtovanju in upravljanju odnosov z več javnostmi tudi v javnem sektorju. Vladne ali državne institucije se namreč v komunikaciji z javnostmi pogosto omejujejo le na en segment komuniciranja, na odnose $\mathrm{z}$ mediji. 


\section{POLITIČNI ODNOSI Z JAVNOSTMI}

Odnosi z javnostmi so sestavni del življenja in delovanja sodobnih družb. Čeprav jim mnogi pripisujejo primernost le za zasebni, korporativni sektor, jih najdemo tudi v državnih ustanovah, v javnem sektorju in civilni družbi. Država s svojimi institucijami stopa $\mathrm{v}$ interakcijo z javnostjo, da »izvaja svoj program in državno politiko ob konsenzu z njo« (Vreg, 2000, str. 77). Med državo in državljani ves čas poteka komunikacija, v katero se vključujejo vlada in njeni organi, politične stranke, korporacije in interesne skupine. Vsi akterji pa nimajo enakega dostopa do »mnenjskega trga« in tudi njihova mnenja nimajo enake teže oziroma vrednosti (Vreg, 2000). Vreg si politično komunikacijsko interakcijo zamišlja v modelu, ko komunikacija poteka od posameznika (od intersubjektivne ravni) prek formalnih in neformalnih skupin do nacionalne ravni države, ki združuje politično (stranke in organizacije, institucije vseh treh vej oblasti), gospodarsko in medijsko področje. Ta raven prav tako interaktivno komunicira z globalno ravnijo, na kateri so mednarodne politične organizacije, mednarodna telesa (OZN, EU, Nato itn.), mednarodne korporacije in medijska industrija (Vreg, 2000). V državah, v katerih institucionalni sistem soudeležbe pri političnem odločanju, ki bi vključevalo državljane v odločevalske procese o javnih zadevah, še ni razvit, državljan spremlja politično dogajanje posredno prek množičnih medijev in formalnih ter neformalnih oblik politične participacije. Formalne oblike potekajo prek parlamenta, političnih strank in interesnih skupin. Neformalne oblike komunikacije pa se kažejo kot izražanje mnenj in stališč neformalnih skupin, ki nastajajo v medosebnem komuniciranju, vključujejo mnenja mnenjskih voditeljev in druge spontane oblike izražanja javnega mnenja.

Pomembne družbene, politične, sociološke in tehnološke spremembe zadnjih desetletij so močno zaznamovale vse vrste komunikacij. Tradicionalno politično komuniciranje je zelo formalno in se izraža predvsem v volilnih kampanjah ter ostaja $\mathrm{v}$ okvirih nacionalnih držav. Kompleksnost sodobnih političnih in družbenih tematik, vprašanj in dilem je postavila politično delovanje v precej obsežnejši vsebinski kontekst in razširila geografski okvir delovanja. Predmet politične komunikacije se je razširil na področje vladanja, oblikovanja javnih politik, gradnjo odnosov z različnimi vrstami javnosti, upravljanje javnih tem in oblikovanje javnega mnenja. Da bi bili uspešni, politični odnosi z javnostmi ne morejo biti omejeni le na razširjanje informacij prek množičnih medijev, temveč morajo biti odgovorni za strateško komuniciranje v imenu svoje organizacije, zadolženi za njeno predstavljanje, pa tudi za zastopanje interesov njenih javnosti. Politični odnosi z javnostmi morajo potekati kot »upravljavski proces, s katerim organizacija ali posamezni akter skuša z namensko komunikacijo in ukrepi v politične namene vplivati in vzdrževati koristne odnose ter ugled s svojimi ključnimi javnostmi, da bi uresničevali svoje poslanstvo in dosegali svoje cilje« (Strömbäck, Kiousis 2011, str. 8). Tako razumevanje temelji na načelih delovanja strateških odnosov z javnostmi, da bi bilo kos zahtevni nalogi pa zahteva tudi povezovalno sodelovanje ter interdisciplinarno združevanje teorij in pristopov političnega komuniciranja, političnega marketinga, odnosov z javnostmi, javnih odnosov in organizacijskega komuniciranja. 
Vojska ima v družbi poseben strateški položaj. Opravlja temeljno poslanstvo obrambe države, pri čemer ima na voljo veliko vojaško silo, družbeno moč in vire. Kot državnoobrambna organizacija je ena najmočnejših interesnih skupin, ki uveljavlja svoje interese nasproti interesom drugih skupin (Vreg, 2000). Čeprav spada med institute državne represije, opravlja tudi pomembno družbeno in socialno vlogo (na primer pomoč ob naravnih in drugih nesrečah). Oborožene sile so v sodobnih demokratičnih družbah ena najbolj razvitih in pomembnih družbenih institucij, s samostojnim podsistemom oskrbovanja, šolstva, zdravstva, svojimi tehničnimi, človeškimi ter znanstvenimi viri in zmogljivostmi. So pod nadzorom civilne oblasti in se vzdržujejo s proračunskim denarjem (Bric, 2008). Legitimnost obrambno-vojaških struktur je v marsičem povezana z legitimnostjo vlade, pa tudi z legitimnostjo, ki jim jo podeljuje demokratična javnost. Ta postaja vse bolj ozaveščena in kritična, zato se pričakuje, da bodo obrambno-vojaške strukture čim bolj upoštevale zahteve in pričakovanja javnosti, da bodo »v komunikaciji z javnostmi iskale skupni jezik, usklajevale različna izkustvena polja in različne interese« (Prezelj 1997, str. 1021-22).

Vojaški odnosi z javnostmi so del neoperativne aktivnosti oboroženih sil, katerih namen je vzpostavljanje ali ohranjanje dobrih odnosov z različnimi javnostmi in ustvarjanje sprejemljive podobe $\mathrm{v}$ javnosti, kar je življenjskega pomena za vsako vojsko (Prezelj, 1997). Vojaški odnosi z javnostmi se navadno ne razlikujejo veliko od odnosov z javnostmi v zasebnem sektorju, uporabljajo enake strateške pristope in enaka orodja, le izdelek je drugačen (Cutlip in drugi, 2004). Ker delujejo v okolju javnega sektorja, so pogosto predmet kritične presoje medijev ter strokovne in tudi laične javnosti. Zato se, tako kot drugod, tudi na področju vojaških odnosov z javnostmi pričakuje visoka stopnja etičnosti in profesionalnosti.

Vojaški odnosi z javnostmi spadajo v širši okvir političnih odnosov, ki jih s svojimi javnostmi vzdržujejo vladne, javne in državne institucije. Vojska mora kot institucija družbenega pomena po zakonu zagotavljati javnost dela. Zakonodaja ji po eni strani nalaga, da komunicira kar se da pregledno, verodostojno in odgovorno z notranjimi in zunanjimi deležniki ${ }^{1}$, po drugi strani pa jo omejuje vrsta drugih zakonov in predpisov. Za odnose z javnostmi v javni oziroma državni upravi velja, da so pogojeni s pravnimi, upravnimi in finančnimi predpisi ter omejitvami, na vojaško-obrambnem področju pa je treba upoštevati še vrsto dodatnih posebnosti. V vojaški organizaciji je izbira pristopov in kanalov komuniciranja omejena zaradi hierarhične linije vodenja in poveljevanja ter načel subordinacije in enostarešinstva; upoštevati je treba spoštovanje vojaške discipline, varovanje informacij in tajnosti podatkov, negovanje tovarištva in domovinske pripadnosti. Ta razmerja se sicer lahko spremenijo, najpogosteje se to zgodi zaradi pritiskov iz zunanjega okolja (množični mediji, strokovna javnost, mednarodno okolje, stopnja ogrožanja, oborožen spopad) (Bric, 2008).

\footnotetext{
Deležniki (angl. stakeholders) so skupine ljudi, ki jih z našo organizacijo vežejo konkretne vezi (poslovne, strokovne, interesne). Odločitve organizacije vplivajo na njihovo delovanje in življenje, prav tako tudi deležniki s svojimi odločitvami in ravnanji vplivajo na organizacijo.
} 
Nameni, vloge in oblike komuniciranja vojaških institucij z javnostjo so se skozi zgodovino spreminjali. Na začetku 20. stoletja je veljalo, da je komunikacija z javnostjo pomembna predvsem med vojnimi spopadi. Njen namen je bil pridobiti podporo domače javnosti za vojne posege, komunicirati namere vojskujoče se države in, kolikor je mogoče, nadzorovati ali usmerjati sporočila za medije oziroma za širšo javnost (Smith, 2005). V miru so se nameni komuniciranja razširili na pojasnjevanje položaja obrambnih struktur, upravičenosti nenehnih investicij v ljudi in opremo, zaposlovanja in izpopolnjevanja kadrov, sodelovanja z lokalnimi skupnostmi in vloge vojaške industrije kot pomembnega gospodarskega dejavnika (Toledano, 2010). S prehodom na poklicno vojsko se oborožene sile predstavljajo tudi kot zanimiva zaposlitvena možnost, kot garant varne zaposlitve in zanesljiva pomoč ob naravnih in drugih nesrečah, kar povečuje zanimanje medijev in javnosti za njihovo delovanje (Prezelj, 1997). Mnoge nacionalne vojske so članice mednarodnih integracij, vpete v mednarodno dogajanje, kar jih pogosto postavlja v središče zanimanja domačih in tujih medijev.

Komunikacija med vojaško in civilno sfero poteka vsaj že od antike, a načini in oblike kot jih poznamo danes, so se oblikovali šele v 20. stoletju. V literaturi so $\mathrm{S}$ strokovnega in poklicnega vidika najpogosteje predstavljeni vojaški odnosi $\mathrm{z}$ javnostmi v ZDA, saj »majo tam na voljo največj aparat, pa tudi eno najbolj razširjenih praks odnosov z javnostmi v svetu« (Smith, 2005, str. 894).

Van Dyke in Verčič (2009) razvrščata razvoj vojaškega komuniciranja v štiri glavna časovna obdobja: obdobji prve in druge svetovne vojne ter obdobji hladne vojne in vojne proti terorizmu, vsako je zaznamovalo tudi komunikacijo z javnostmi. Avtorja navajata ugotovitve ameriških, britanskih in nemških raziskovalcev, ki pričajo, da so se funkcije in oblike delovanja med obdobji močno spreminjale. Med prvo in drugo svetovno vojno je bilo komuniciranje centralizirano. Vsebino so nadzorovali in cenzurirali, najbolj razširjeni komunikacijski tehniki sta bili propaganda in publiciteta. Z vse večjo demokratizacijo držav po drugi svetovni vojni so začeli tudi v vojaških sistemih ločevati propagando od drugih oblik komuniciranja. Uveljavljati se začnejo odnosi z javnostmi kot oblika strateškega upravljanja komunikacij in reševanja konfliktov ter javna diplomacija kot neposredna komunikacija vlad s tujimi voditelji in javnostmi drugih držav. V obdobju hladne vojne sta se obe disciplini še bolj uveljavili in povezali ter postali del odločevalskega procesa. V tem obdobju se je uveljavila ločitev odnosov z javnostmi in javne diplomacije od informativno-obveščevalnega delovanja ${ }^{2}$, katerega cilji so kljub komplementarnosti drugačni. V obdobju vojne proti terorizmu, ko so informacije postale sredstvo boja proti domačim in mednarodnim teroristom, so se odnosi z javnostmi, javna diplomacija, psihološko delovanje in propaganda spet nevarno povezali, postavili so jih v prve bojne linije. Tako ravnanje pa pomeni velik korak od uveljavljene strokovne in profesionalne vloge, ki se je že uveljavila v 20. stoletju.

\footnotetext{
Namen takega delovanja je usmerjanje informacij le k posebej določenim ciljnim skupinam, da se nanje vpliva oz. pridobijo prednosti ene ali več nasprotujočih si strani. Izvaja se v različnih oblikah in kombinacijah z uporabo psihološkega delovanja (Bric, 2008).
} 
Družbene spremembe $\mathrm{v}$ zadnjih desetletjih (povečana demokratizacija, spreminjanje vrednot, globalizacija, uvedba novih tehnologij, vloga mediacije v družbi) so vplivale na spremembe vojaških doktrin (npr. zmanjševanje vojaških struktur, prehod na poklicno vojsko, članstvo v evroatlantskih povezavah, sodelovanje v mednarodnih operacijah in na misijah). Pravo revolucijo v komuniciranju z javnostmi prinesejo internet in sodobni medijski pristopi, ki uradne obrambne vojaške strukture skoraj popolnoma »razorožijo«. Mediji in strokovna ter laična javnost s pomočjo različnih tehnoloških in komunikacijskih kanalov in sredstev, ki omogočajo hitro razpoložljivost in objavo informacij ter podob, pogosto prehitevajo uradne vire, jim onemogočajo cenzuro (predvsem z bojnih območij) oziroma jih silijo k verodostojni komunikaciji z njimi.

Opaziti pa je tudi spremenjen odnos javnosti do oboroženih sil. Moskos navaja, da je (ameriška) javnost med obema vojnama kljub občasnim dvomom ter kritičnosti intelektualcev in medijev močno podpirala vojsko kot institucijo. V zadnjih desetletjih je odnos postal skeptičen in brezbrižen. Ko je bil ukinjen naborniški sistem, se je zanimanje za vojsko zmanjšalo. Spremenil se je tudi odnos do vojnih žrtev, saj vojak z odločitvijo za vojaški poklic sprejme večje tveganje. V postmodernem obdobju se vojski odreka brezpogojna podpora ter se dvomi v smotrnost in upravičenost njenega ravnanja. Obrambno-vojaške strukture sicer imajo legitimno pravico, da obveščajo javnost o svojem delovanju, a so hkrati ves čas pod kritično presojo javnih institucij, medijev in javnosti, ko poskušajo obveščati, še zlasti pa zagovarjati svoja stališča in prepričevati javnost oziroma vplivati na javno mnenje (Moskos v Bric, 2008).

Za vojaške odnose z javnostmi so na začetku 20. stoletja, posebno v obdobju obeh svetovnih vojn, skrbele posebne komisije oziroma specializirani uradi za vojne informacije. Pozneje se je dejavnost centralizirala $v$ ministrstvih za obrambo, ki so ustanovila posebne organizacijske enote za odnose $\mathrm{z}$ javnostmi. Te službe danes opravljajo širok spekter različnih dejavnosti in v nekaterih državah zaposlujejo po več sto strokovnjakov. Za načrtovanje, vodenje in ocenjevanje komunikacijskih dejavnosti imajo na voljo svoje analitske oddelke, oddelke za strateško načrtovanje in upravljanje komunikacij z domačo in mednarodno javnostjo ter sodobne produkcijske sisteme (publicistika, radio, TV, video, spletni mediji).

Področje vojaških odnosov z javnostmi je široko; največ dejavnosti je namenjene odnosom z internimi javnostmi in mediji kot posredniki sporočil do širše javnosti ter sodelovanju z lokalnimi skupnostmi (Cutlip in drugi, 2004).

\section{ODNOSI Z JAVNOSTMI NA OBRAMBNO-VOJAŠKEM PODROČJU V SLOVENIJI}

Odnosi z javnostmi v slovenski javni in državni upravi so mlada dejavnost, oddelkov ali služb razen redkih izjem (npr. na ministrstvu za notranje zadeve) pred začetkom devetdesetih let ni bilo. Kot podlago za njihovo organiziranost lahko vzamemo sklepe vlade, ki je na seji decembra 1994 ob obravnavi gradiva o delovanju in 
organiziranosti Urada Vlade RS za informiranje v enem izmed sklepov »naložila vsem ministrstvom, da v najkrajšem času na podlagi zakona o javnih glasilih $\mathrm{s}$ svojimi akti uredijo način zagotavljanja javnosti dela, način dajanja informacij za javnost in določijo osebo, ki bo odgovorna za zagotavljanje javnosti dela« (Serajnik in Vidrih, 2001, str. 656). V nekaj letih je večina vladnih institucij imenovala osebe za odnose z javnostmi in ustanovila pristojne službe ali oddelke.

Osrednja služba za odnose z javnostmi na Ministrstvu za obrambo (MO) je bila ustanovljena leta 1998, pred tem pa so bili odnosi z javnostmi vse od ustanovitve organizirani v Kabinetu ministra, v katerem je bila za to področje imenovana pooblaščena oseba. Danes ta služba deluje pod imenom Služba za strateško komuniciranje, ker je po reorganizaciji ministrstva leta 2011 razširila svoje delovanje tudi na področje publicistike, založništva ter multimedijske produkcije in podpore. Deluje kot samostojna organizacijska enota, ki je pristojna in odgovorna za vodenje, načrtovanje in izvedbo. Odgovorna je tudi za usklajevanje odnosov z javnostmi na celotnem ministrstvu, vključujoč organe v sestavi ministrstva (Slovensko vojsko, Upravo RS za zaščito in reševanje, Inšpektorat za obrambo in Inšpektorat za varstvo pred naravnimi in drugimi nesrečami).

Služba zagotavlja celovito in sprotno obveščanje javnosti o delu ministrstva, organizira ter usklajuje načrtno in proaktivno sodelovanje z vsemi javnostmi, pri čemer posebno pozornost namenja odnosom z mediji in komunikaciji z notranjo javnostjo. Skrbi za multimedijsko produkcijo in javno podobo ministrstva. Ima ustrezna pooblastila, ki ji omogočajo, da od posameznih organizacijskih enot in organov v sestavi ministrstva zahteva strokovne podlage in podatke, na podlagi katerih lahko pripravi sporočila in obvestila za javnost, odgovore, popravke ter druge javne informacije.

\section{3 ŠTUDIJSKI PRIMER - KOMUNIKACIJSKA KAMPANJA V PODPORO VKLJUČEVANJU SLOVENIJE V NATO}

Komunikacijskih primerov iz obrambno-vojaške prakse v slovenski strokovni literaturi skoraj ni najti. V prispevku želim predstaviti študijski primer komunikacijskega programa in referendumske kampanje v podporo vključitvi Slovenije v Nato. Primer bi lahko bil zanimiv za bralce, ne samo zaradi celovite predstavitve kampanje, $\mathrm{v}$ kateri so aktivno sodelovali tudi predstavniki Slovenske vojske, temveč tudi zaradi vsebine, kritik in vprašanj, ki jih je kampanja sprožila. To kampanjo lahko glede na namen uvrstimo med politične, a jo je vredno obravnavati tudi z vidika prakse vojaških odnosov z javnostmi. Strokovna in civilna javnost sta odločitev za vstop države v Nato razumeli sicer kot politično vprašanje, a so ju bolj kot njena politična narava zanimale vsebine obrambno-tehnične narave. Razprave, ali in zakaj bi Nato Sloveniji dajal ustrezen obrambno-varnostni okvir, kako bi vstop vplival na položaj vojske, kako bi se vojaške strukture vključevale v Natovo mednarodno sodelovanje, kakšni bi bili obrambni stroški, kako bi se vojska prilagajala Natovim standardom ipd., so zavzele večinski del kampanje. Na ta vprašanja politiki in tudi strokovnjaki niso vedno znali ali hoteli dati pravih odgovorov, saj se je država šele pogajala 
o pogojih vstopa in prihodnjega sodelovanja. Kampanja je potekala že pred več kot desetimi leti, komunikacijski pristopi in oblike dela sodelujočih so se medtem že posodobili, a mnoga vprašanja še ostajajo.

\subsection{Institucionalni okvir}

Republika Slovenija je med ključne zunanjepolitične cilje po osamosvojitvi uvrstila vključitev v Evropsko unijo in Nato. Ti strateški prednostni nalogi so potrdile vse vlade in vsi sklici parlamenta; z njima se je strinjala večina političnih strank. Nacionalno strategijo vključevanja v Nato sta Vlada RS in Državni zbor potrdila leta 1998.

Slovenija je za vključitev v Nato prvič kandidirala na madridskem vrhu (1997), a ni bila sprejeta. Na vrhu v Washingtonu (1999) zavezništvo ni sprejelo nobene države, pač pa je uvedlo institut akcijskega načrta za članstvo ${ }^{3}$, ki ga je Slovenija, tako kot druge države kandidatke (Bolgarija, Romunija, Slovaška in baltske države), začela dosledno izpolnjevati.

\subsection{Javno mnenje pred kampanjo}

Raziskava Politbarometer ${ }^{4}$, ki med drugim meri odnos slovenske javnosti do vplivnih institucij (odnos do Nata in od leta 1997 do vključevanja vanj) ter poglobljene terenske raziskave ${ }^{5}$ kažejo, da je bilo slovensko javno mnenje na splošno naklonjeno vključevanju v Nato. Podpora vstopu vanj je bila do leta 1997 visoka (55-62 odstotkov), po vrhu v Madridu pa se je začela zniževati (občasno skoraj za 10 odstotkov). Vstopu v Nato so bili nenaklonjeni v starostnih skupinah od 30 do 60 let, višje izobraženi in pripadniki leve politične opredelitve.

Terenske raziskave so razkrile razloge za podporo oziroma nasprotovanje. Kljub visoki podpori so vprašani nasprotovali večjim obveznostim zaradi članstva (povečanje finančnih sredstev za obrambo, odhajanje slovenskih vojakov na tuja bojišča). Slovenci se niso počutili ogrožene, grožnje so zanje predstavljali mednarodni kriminal, tihotapljenje drog in imigrantov, onesnaževanje okolja ter bolezni. Obrambno funkcijo vojske so prepoznavali predvsem v mednarodnem kontekstu, znotraj države pa so izpostavljali njeno nevojaško poslanstvo (varovanje človekovih pravic, mednarodnega prava, zagotavljanje človekoljubne pomoči, sodelovanje v mirovnih operacijah). Med organizacijami, ki bi bile sposobne »narediti red« v

\footnotetext{
Akcijski načrt za članstvo (Membership Action Plan) je temeljni dokument, na podlagi katerega se posamezne države kandidatke pripravljajo na članstvo v Natu. V ta namen kandidatke pripravijo svoje letne nacionalne programe, ki obsegajo ta področja delovanja: politično-ekonomsko, obrambno-vojaško, viri, varnost in pravne zadeve.

${ }_{4}$ Raziskave opravlja Center za raziskovanje javnega mnenja pri Fakulteti za družbene vede. Vsi podatki iz raziskav Politbarometer so dostopni na http://www.cjm.si/arhiv_pb. Podatki o raziskavah javnega mnenja ob vključevanju v Nato so zbrani tudi na naslovu: http://nato.gov.si/slo/javno-mnenje/.

5 Terenske raziskave izvaja Obramboslovni raziskovalni center v okviru Inštituta za družbene vede Univerze v Ljubljani. Javnomnenjske raziskave s področja varnosti potekajo že vrsto let, prvič so leta 1994 vanje vključili vprašanja, ki se nanašajo na potencialno članstvo v Natu. Take raziskave so bile opravljene še leta 1999, 2001 in 2003 .
} 
Evropi in bi Sloveniji, če bi bila ogrožena, priskočile na pomoč, so navajali Nato. O Natu in slovenskih namerah za vstop so bili slabo obveščeni, takšne informacije jih tudi niso zanimale. Skoraj 77 odstotkov vprašanih pa je menilo, da bi morali odločitev za vstop v Nato potrditi na referendumu (Malešič, 2002).

Analiza medijskega poročanja je pokazala, da slovenski mediji o vključevanju Slovenije v Nato pred letom 2000 niso veliko poročali, poročanje je bilo večinoma nevtralno. V civilni družbi do leta 2000 ni bilo odmevnejših nasprotovanj za vstop; občasno so se postavljala le vprašanja o koristih članstva Slovenije v evroatlantskih integracijah.

\subsection{Strateški program komuniciranja}

Ko so se konec leta 2000 intenzivirale priprave Slovenije na vstop v Nato, se je vlada odločila okrepiti obveščanje slovenske javnosti o postopkih približevanja ter o prednostih in obveznostih, ki jih članstvo v Natu prinaša. Ker so na ministrstvih za obrambo in za zunanje zadeve ugotovili, da tematika vključevanja presega njihove resorne pristojnosti, je vlada nalogo dodelila Uradu Vlade RS za informiranje, ki je tedaj že vodil komunikacijski program za vstop Slovenije v Evropsko unijo.

Urad je v okviru nacionalne medresorske delovne skupine za sodelovanje z Natom ${ }^{6}$ oblikoval medresorsko delovno podskupino (IK) ${ }^{7}$, skupaj z njo pripravil predlog komunikacijske strategije in skrbel za njegovo izvajanje. V strateškem načrtovanju komuniciranja sta bila MZZ s Stalno misijo pri Natu in MO s Slovensko vojsko ključna vsebinska partnerja. V izvedbenem delu kampanje pa so bili predstavniki MO in SV precej bolj izpostavljeni zaradi vsebine javnih razprav.

Strategija je predvidela celovit, kontinuiran in usklajen program ozaveščanja javnosti v Sloveniji in mednarodni skupnosti, in sicer sprva za obdobje slabih dveh let (od sredine 2001 do konca leta 2002), razdeljeno na obdobje pred vrhom Nata jeseni 2002 in po njem. Cilja komunikacijskega programa v Sloveniji sta bila:

- doseči poenoten in usklajen vsebinski ter izvedbeni komunikacijski pristop ministrstev in vladnih služb v internih javnostih (znotraj državne uprave);

- zagotoviti razumevanje in podporo slovenske javnosti za vstop v zavezništvo s posredovanjem celovitih, razumljivih in verodostojnih informacij o poteku vključevanja in pomenu članstva ter omogočanje javne razprave.

\footnotetext{
6 Medresorsko delovno skupino (MDS) sta vodili Ministrstvo za zunanje zadeve in Ministrstvo za obrambo. Stalni člani so bili predstavniki Generalštaba Slovenske vojske, Stalne misije RS pri Natu in ministrstev za gospodarstvo, finance, kmetijstvo, gozdarstvo in prehrano, notranje zadeve, okolje in prostor, pravosodje, promet, zdravstvo ter za šolstvo, znanost in šport, poleg teh pa še Kabineta predsednika Vlade ter Urada Vlade $R S$ za informiranje.

Informacijsko-komunikacijsko delovno skupino so sestavljali predstavniki ministrstev za zunanje zadeve in za obrambo, Slovenske vojske, Misije RS pri Natu in Urada Vlade RS za informiranje, ki jo je vodil. Med referendumsko kampanjo je IK-skupina sodelovala z zunanjim komunikacijskim svetovalcem, v izvedbenem delu (grafično oblikovanje, priprava za tisk, zakup medijskega prostora) pa z marketinško agencijo.
} 
Vsebine komuniciranja so bile osredotočene na dve glavni temi: predstavitev zavezništva (sestava, poslanstvo, vloga, oblike delovanja) ${ }^{8}$ in proces slovenskega vključevanja vanj. Največ pozornosti je bilo namenjene predstavitvi argumentov za vključitev mogočih oblik zagotavljanja nacionalne varnosti, obveznosti članstva, pravnih vidikov vključitve ter nevojaškim vidikom sodelovanja (civilno krizno načrtovanje in upravljanje, znanstveno, medicinsko in ekonomsko sodelovanje).

S komunikacijskimi aktivnostmi smo v slovenski javnosti nagovarjali množične medije (kot posredovalce sporočil za vse javnosti), predstavnike političnih in strokovnih javnosti, nevladnih organizacij, mladih in internih javnosti.

V strategiji smo predvideli nabor komunikacijskih kanalov in tehnik: redno sodelovanje s slovenskimi in tujimi mediji, izdajo informativnih publikacij (za interne in strokovne javnosti, mlade, državljane), zagotavljanje kanalov za neposredno komunikacijo z državljani (postavitev enotne spletne strani na internetu (http://nato.gov. si), odprtje telefonske linije za vprašanja), javne dogodke (razprave, okrogle mize in predavanja za različne javnosti, na različnih lokacijah in z različnimi gosti), študijske obiske na sedežu Nata (za novinarje, parlamentarce, študente, druge mnenjske voditelje) in izobraževalne dogodke (predvsem za interne javnosti). Program je imel tudi svojo celostno grafično podobo, s katero smo želeli doseči večjo prepoznavnost in opozoriti na enoten nastop vseh sodelujočih.

$\mathrm{S}$ strategijo smo predvideli tudi komunikacijo $\mathrm{z}$ mednarodnimi strokovnimi javnostmi - z oblikovalci javnega mnenja (novinarji, komentatorji) in oblikovalci odločitev (politiki, diplomati, državni uradniki, politični svetovalci na sedežu zveze in v vseh 19 državah članicah). Namen komuniciranja v mednarodnih strokovnih javnostih je bil prispevati k večji prepoznavnosti Slovenije kot mogoče članice zavezništva, jasno izraziti razloge in pomen vključitve za obe strani ter predstaviti slovenska prizadevanja in dosežke.

\subsection{Izvedba komunikacijskega programa}

Prva faza (od aprila 2001 do marca 2002): postavitev informacijske infrastrukture

Prvo leto smo se s komunikacijskimi dejavnostmi osredotočili predvsem na sodelovanje $\mathrm{z}$ internimi in strokovnimi javnostmi. Projekt je povezoval predstavnike številnih državnih ustanov. Da bi bil njihov nastop čim bolj usklajen, je bilo treba omogočiti, da so se med seboj dobro spoznali, se delovno uglasili, prepoznali vse posebnosti vstopnega procesa in se dogovorili za usklajeno sodelovanje. Komunikacija z njimi je potekala prek različnih gradiv, prispevkov in zapisov $\mathrm{v}$ informativnih publikacijah, na izobraževalnih delavnicah in seminarjih. Vsebinsko smo podrobneje predstavljali zavezništvo (strukturo Nata, način delovanja in odločanja) in proces slovenskega vključevanja (izpolnjevanje meril, povečanje deleža BDP za obrambo, vključevanje SV v operacije zunaj Slovenije, zagotavljanje podpore javnosti, pravne

\footnotetext{
8 Nato sicer ima svoj oddelek za odnose z javnostmi, a je tedaj veljala politika, da zavezništvo in razloge za včlanitev vanj predstavljajo države kandidatke.
} 
vidike vključitve). $\mathrm{V}$ tem obdobju smo vzpostavili tudi sodelovanje s strokovnimi javnostmi (strokovnjaki za mednarodno politiko, mednarodno pravo, varnostno in obrambno tematiko) ${ }^{9}$; njihovi predstavniki so z nami sodelovali pri pripravi strokovnih razlag in argumentov ali kot govorci v javnih razpravah.

Druga faza (od aprila do novembra 2002): razširjen program ozaveščanja javnosti

Vrh Nata v Pragi (november 2002) je obetal povabilo v zavezništvo, hkrati se je okrepila javna razprava o smiselnosti članstva. Javna podpora se je gibala okrog 50 odstotkov. Delež nasprotnikov vstopa se je zadrževal na približno 36 odstotkih, delež neopredeljenih je nihal med 16 in 21 odstotki. V raziskavah smo prvič preverili namero udeležbe na referendumu. Kar 83 odstotkov vprašanih je potrdilo zahtevo po referendumu. Razpravo o vstopu je spremljalo 63 odstotkov vprašanih, 31 odstotkov pa tematika ni zanimala ${ }^{10}$.

Ti podatki so vplivali na odločitev, da se ozaveščanje iz ozkih strokovnih okvirov razširi na vso slovensko javnost, da bi dosegli večje razumevanje namere za vstop in večjo podporo. Razširili in poglobili smo sodelovanje $\mathrm{z}$ nacionalnimi mediji, pa tudi z regionalnimi in lokalnimi radijskimi in TV-postajami, ki so pokazale večje zanimanje za sodelovanje kot nacionalni mediji. Komuniciranje se je osredotočalo okrog glavnih vsebinskih tem, kot so zagotavljanje varnosti, modernizacija in profesionalizacija vojske ter prihodnja vloga Slovenije v mednarodni skupnosti. $\mathrm{Ob}$ številnih vojaških vprašanjih, ki so jih zastavljali v kritični javnosti, smo poskušali nazorno razložiti prednosti in obveznosti članstva, pa tudi sodelovanje Nata in njegovih zaveznic na nevojaških področjih (zaščita okolja, civilna zaščita, medicina, gospodarstvo). V program smo vključili nove govorce (poleg političnih predstavnikov še vladne in nevladne strokovnjake) ter uvedli nove, neposredne oblike komuniciranja z državljani (brezplačno telefonsko številko za klice državljanov Natofon, poštni naslov Natonabiralnik, interaktivno rubriko na spletni strani). Informativno publikacijo Natopis, v kateri smo odgovarjali na najbolj vroča vprašanja, so dobila vsa gospodinjstva. Odgovore na največkrat zastavljena ali najbolj vroča vprašanja smo zbrali v knjižici pogostih vprašanj in odgovorov ter jo redno dopolnjevali. Da bi ljudi usmerili na javno dostopne informacijske vire, smo številke in naslove za zastavljanje vprašanj občasno oglaševali v tiskanih medijih in na spletnih brskalnikih.

\section{Tretja faza (od januarja do marca 2003): referendumska kampanja}

Slovenija je ob koncu leta 2002 dobila uradno povabilo v članstvo. Povabilo je okrepilo javno razpravo, ki se je stopnjevala do odločitve, da bo za potrditev politične odločitve o vstopu potreben referendum. Razgreta politična razprava o vrsti referenduma je potekala dva meseca in močno vplivala na javnomnenjske rezultate.

\footnotetext{
9 Atlantski svet Slovenije, Odbor za Nato, Fakulteta za družbene vede-Katedra za obramboslovje, Pravna fakulteta, Ekonomska fakulteta.

${ }^{10}$ Podatki iz rednih mesečnih javnomnenjskih raziskav - dostopni na spletni strani http://nato.gov.si/slo/javnomnenjel.
} 
Raziskave so na začetku leta 2003 kazale na velika nihanja v javnem mnenju (za 37-48 odstotkov, proti 28-39 odstotkov, neopredeljeni 17-23 odstotkov). Višje vrednosti so pokazali odgovori tistih, ki so potrdili, da bodo šli na referendum in glasovali (za 56-65 odstotkov, proti 35-44 odstotkov) ${ }^{11}$.

Državni zbor je januarja 2003 odločil, da bo 23. marec 2004 skupni datum referendumov za vstop Slovenije v Nato in EU. Ker sta bila referenduma predvidena na isti dan, se je vlada odločila povezati oba komunikacijska programa v eno kampanjo pod enotnim geslom Doma v Evropi, varni v Natu. Glasovanje bi potekalo ločeno, z dvema ločenima vprašanjema na dveh ločenih glasovnicah.

Odločitev za referendum je pomenila, da se je komunikacijski program čez noč spremenil v referendumsko kampanjo. Z usmerjeno in poglobljeno komunikacijo smo si prizadevali okrepiti nacionalni konsenz, ki bi se odrazil v čim boljši referendumski udeležbi in pozitivnem glasovanju za vstop. V obeh kampanjah smo predstavljali številne argumente zanj. Zaradi kritičnega odnosa javnosti do vstopa v Nato je bilo več pozornosti namenjene utemeljevanju prednosti in priložnosti, ki jih vstop v Nato prinaša (kolektivna varnost, regionalna stabilnost, nižji stroški za vojsko, lažja profesionalizacija Slovenske vojske), pa tudi pojasnjevanju obveznosti (udeležba vojske v skupnih akcijah Nata, višji obrambni proračun). V sklepnem delu kampanje smo nagovarjali zlasti neopredeljene in zagovornike.

Okrepljeno sodelovanje z mediji je potekalo v znamenju številnih javnih razprav, posebno v elektronskih medijih. Izšle so nove informativne publikacije, dve so prejela vsa gospodinjstva. Po vsej Sloveniji so potekale številne javne razprave in soočenja. V osrednjem dnevniku smo objavili besedilo Severnoatlantske pogodbe, ki naj bi jo podpisala država ob vstopu v zvezo. Z objavo »Natofaktov« (dejstva, argumenti, vroča vprašanja in odgovori) na televiziji, radiu in v osrednjih tiskanih medijih ter s pričevanji politikov in strokovnjakov na regionalnih radijskih in TVpostajah, v katerih so sodelovali zagovorniki in nasprotniki, smo poskusili soočiti vsa mnenja in argumente. Za ljudi sta bila na voljo odprta telefonska linija Natofon in poštni Natonabiralnik, njune naslove smo oglaševali z izdajo informativnih kartic, na spletnih brskalnikih in $\mathrm{v}$ tiskanih medijih.

Sodelovanje s tujimi strokovnimi javnostmi je bilo intenzivno v vseh fazah programa, še posebej v drugi in referendumski fazi. Komuniciranje je potekalo na več ravneh, na politični, diplomatski, strokovni in medijski, in sicer v obliki izdaje specializiranih publikacij (Nato Facts sheets, angleška izdaja revije Slovenska vojska), z objavo člankov in prilog (v Nato Review, Nato Nation's, Slovenia Weekly), kot dogodki (študijski obiski na sedežu Nata, v Shape in državah članicah; obiski visokih Natovih predstavnikov v Sloveniji), komunikacije na spletnem mestu projekta, organizacija medijskih dogodkov (študijski obiski, srečanja z diplomati, tematsko gradivo) ipd.

${ }^{11}$ Podatki za januar, februar in marec 2003 (Politbarometer). 


\section{Četrta faza (od marca 2003 do maja 2004): poreferendumsko obdobje}

Vlada je v časovnici reform zapisala, da bo tudi po referendumu skrbela za redno obveščanje javnosti. V tem obdobju so se nadaljevale zastavljene vojaške reforme, slovenski predstavniki so se aktivneje vključili v Natove odbore in druge aktivnosti zavezništva, spremljali smo ratifikacijske postopke v državah članicah ter sodelovanje slovenskih predstavnikov $\mathrm{v}$ mednarodnih varnostnih pobudah in odločitvah $\mathrm{v}$ regiji ali znotraj zavezništva (angažiranje Nata v Jugovzhodni Evropi, Afganistanu, Iraku).

Po referendumu so se komunikacijske aktivnosti močno skrčile in se osredotočile na strokovno in interno javnost. Komuniciranje je večinoma prešlo v pristojnost Ministrstva za obrambo, Slovenske vojske, Ministrstva za zunanje zadeve in Stalne misije RS pri Natu. Večje komunikacijske aktivnosti (vzdežavanje skupnega spletnega mesta, prevodi tematske literature, organizacija izobraževalnih dogodkov in dogodkov ob podpisu Severnoatlanstke pogodbe, študijski obiski) pa je še vedno usklajevala IK-skupina.

\subsection{Uspešnost komunikacijskega programa}

Učinke komunikacijskih aktivnosti smo spremljali z mesečnimi javnomnenjskimi merjenji (Politbarometer), s kvalitativno in kvantitativno analizo medijskega odmeva, spremljanjem števila vprašanj, zastavljenih na Natofonu, prek spletnega mesta in Natonabiralnika, $\mathrm{z}$ ocenjevanjem njihove vsebine ter analizo udeležbe in odmevov na javnih razpravah.

Med uresničevanjem komunikacijskega programa smo izdali šest informativnih publikacij v skupni nakladi približno 15,5 milijona izvodov; tri izmed njih so dobila vsa gospodinjstva, druge pa knjižnice, šole, fakultete, mediji, nevladne organizacije, župani, mestne občine, upravne enote, politične stranke, člani Državnega sveta in Državnega zbora ter širša državna uprava.

Prek odprte telefonske linije Natofon smo odgovorili na skoraj 1000 vprašanj, prek spletne strani pa na nekaj več kot 500. Spletno mesto je redno obiskalo med 30 in 50 tisoč obiskovalci na mesec. Največ obiska so imele rubrike tema meseca, medijsko središče, pogosta vprašanja in koledar dogodkov. Sedež Nata je obiskalo več kot 700 slovenskih predstavnikov, od tega več kot 400 študentov. Javne razprave in predavanja so bila posebej zgoščena $\mathrm{v}$ zadnjih mesecih pred referendumom, samo zadnji mesec jih je bilo 42 . V elektronski bazi Infoklip se je nabralo nekaj tisoč medijskih zapisov, ki so posledica poročil, izjav, intervjujev, soočenj, kontaktnih oddaj in okroglih miz v medijih.

Javnomnenjska raziskava po referendumu ${ }^{12}$ je pokazala, da je 59 odstotkov vprašanih ocenilo članstvo kot koristno; sodelovanje SV so videli v humanitarnih operacijah brez orožja (87,3 odstotka), predvsem na območju nekdanje Jugoslavije.

\footnotetext{
12 Javnomnenjska raziskava Nacionalna in mednarodna varnost 2003 (izvedena okt.-nov. 2003). Inštitut za družbene vede. Obrambni raziskovalni center, Ljubljana.
} 
Pravi pokazatelj uspešnosti kampanje je referendumski rezultat. Po podatkih Republiške volilne komisije je na referendumu 23. marca 2003 glasovalo 974.988 volivcev (60,43 odstotka vseh volivcev). Na referendumsko vprašanje: »Ali se strinjate, da Republika Slovenija postane članica Organizacije Severnoatlantske pogodbe (Nato)?« je strinjanje s članstvom potrdilo 637.882 volivcev $(66,08$ odstotka), proti vstopu je glasovalo 327.463 volivcev (33,92 odstotka). Republiška volilna komisija je razglasila, da se večina volivcev, ki so veljavno glasovali, strinja, da Republika Slovenija postane članica Organizacije Severnoatlantske pogodbe.

\section{KRITIČNI POGLEDI NA KAMPANJO}

Cilj vsake demokratične politike je doseganje konsenza oziroma mnenjskega soglasja o nekem vprašanju splošnega javnega interesa. Če v procesu oblikovanja mnenj ne dosežemo soglasja, ostane javno mnenje razcepljeno (Vreg, 2000). Vstop v Nato je bil izjemno pomembna odločitev za politiko, medije in javnost, zato je bilo treba, še zlasti po odločitvi za referendum, zagotoviti informacije, da bi se državljani lahko izrazili o vstopu. Obdobja pred referendumom so čas intenzivne izmenjave različnih mnenj; predstavniki različnih interesov se zato bolj intenzivno angažirajo in so zainteresirani za takšen ali drugačen izid. Javnost se pogosto sprašuje o njihovi legitimnosti, objektivnosti in prepričljivosti. Množični mediji igrajo pri oblikovanju in izvajanju varnostne politike več vlog: zagotavljajo vez med vlado in državljani, so vir informacij za uradnike, zagotavljajo analize in postavljajo pod vprašaj modrost političnih odločitev. Podobno vplivni posamezniki vplivajo na mnenja in vedenje civilne družbe (Malešič, 2002).

Konfliktnost in pomembnost tematike silita akterje $\mathrm{v}$ agresivnejše metode odnosov z javnostmi. Praviloma imajo uradni viri boljši dostop do medijev, a tudi neuradni (nevladne organizacije, interesne skupine, običajni ljudje) si lahko dostop do medijskih kanalov izborijo s prizadevnostjo, primernimi informacijami in bližino (Poler Kovačič, 2004).

Vstop v Nato je pomenil za politiko, medije in javnosti »temo posebnega družbenega pomena« (Poler Kovačič, 2004, str. 700). Pripravljalni postopki, obveščanje javnosti in referendumska kampanja so sprožili v javnostih mnoge, tudi zelo kritične odzive, ki so se še posebej zaostrili tik pred referendumom. Takrat je bila polarizacija mnenj tako močna, da izida referenduma praktično ni bilo mogoče napovedati. Referendumski rezultat je politični eliti prinesel olajšanje, mediji in javnosti pa so vsaj še do podpisa pogodbe (maja 2004) kritično spremljali dogajanje.

Kritično refleksijo o obdobju priprav pred vstopom in po njem, o različnih odločitvah in potezah opravljajo v Slovenski vojski, deloma tudi v akademski sferi ${ }^{13}$. Poglobljene analize o kampanji in različnih pristopih komuniciranja, razen analiz

\footnotetext{
${ }_{13}$ Izdaja posebne številke revije Biltena Slovenske vojske ob 5. obletnici vstopa Slovenije v Nato in 60-letnici Nata (novembra 2009); Teorija in praksa, letnik 39 (3), 2002.
} 
javnega mnenja in raziskave o nekaterih vidikih medijskega delovanja ${ }^{14}$, v strokovni literaturi ni zaslediti.

Malešič (2002) navaja, da bi glavne očitke, nejasnosti, dvome in zavračanja lahko strnili v štiri vsebinske sklope: nejasna vloga Nata, dvomi o koristih vključitve in oblikah zagotavljanja nacionalne varnosti ter pristranskost informiranja javnosti. Program ozaveščanja javnosti je potekal v času, ko so mednarodno javnost pretresale posledice 11. septembra, ameriška odločitev za vojno v Iraku, razhajanja in transformacije v Natu. Prihodnja vloga in poslanstvo Nata sta bila precej nejasna. Nato tedaj ni vodil politike aktivnega obveščanja javnosti, kot je to počela Evropska unija, zato so bile kandidatke ${ }^{15}$ prisiljene ob pojasnjevanju razlogov za vključitev države v zvezo »promovirati« hkrati še Nato. V naelektrenem protiameriškem ozračju in ob odsotnosti jasnih stališč Nata o prihodnji vlogi so argumenti v prid smiselnosti obstoja in delovanja zavezništva dostikrat naleteli na gluha ušesa. Razprave o načrtih za vstop so posebno v civilni družbi obudile vprašanja o smiselnosti vključitve v zavezništvo. Za mnoge kritike je bil Nato preživeta tvorba, ki po koncu hladne vojne ni bila več potrebna. Čeprav smo se tedaj že soočali z grožnjami mednarodnega terorizma, je v javnosti prevladalo stališče, da Nato ni zmožen zagotoviti učinkovite obrambe proti terorizmu. Slovenija je veljala za vojaško neogroženo. Kritiki so menili, da bi se s članstvom izpostavila novodobnemu terorizmu ter se po nepotrebnem vpletla $\mathrm{v}$ tuje spopade. Vključitev so razumeli kot nabiranje političnih točk za politike, državi naj ne bi prinesla nobenih večjih koristi, le visoke finančne obveznosti. Namesto članstva v Natu so kritiki kot alternativo omenjali nevtralnost ali oboroženo nevtralnost ${ }^{16}$.

Kritičnost se je izražala v prispevkih v medijih, komentarjih, izjavah, soočanjih, na okroglih mizah ali v razpravah. Bebler (2002) meni, da mnogih dogodkov ne gre šteti za pravo javno razpravo, ker so bili enostranski, opozarja na močno zastopanost civilne družbe in odsotnost uradnih predstavnikov. V nastopih majhne, a zelo glasne skupine nasprotnikov vstopa, pravi Bebler, se je v javni obravnavi nakopičilo nekaj deset spornih, neutemeljenih ali celo neresničnih trditev, ki so jih mediji nekritično povzemali. Med kritiki so bili radikalni pacifisti, okoljevarstveniki, anarhistični nasprotniki, ki so se zavzemali za popolno razorožitev, razpustitev Slovenske vojske, prepoved rabe jedrske energije in boj proti svetovnemu kapitalizmu. Po njihovem mnenju bi bilo za varnost države že dovolj članstvo v OZN, OVSE ali EU, za katere pa je znano, da takega varstva ne morejo zagotoviti. Kritiki so z nasprotovanjem izražali tudi, da ne podpirajo trenutne oblasti.

Poler Kovačič (2004) navaja, da je bilo poročanje medijev o pripravah na vstop v Nato v javnosti pogosto ocenjeno kot enostransko oziroma pristransko, zlasti z vidika dostopa virov informacij do medijskih objav in objave njihovih mnenj. Raziskava

\footnotetext{
14 Poler Kovačič, Teorija in praksa 41 (3/4), 2004.

${ }^{15}$ Takega nasprotovanja, kot ga je bilo čutiti v Slovenji, ni bilo nikjer. Prav tako tudi nobeni od kandidatk ni bilo treba politične odločitve za članstvo potrditi na referendumu, zato so bili njihovi programi obveščanja bistveno manj obsežni in intenzivni.

${ }^{16}$ Nihče od kritikov ni javno pojasnil, ali je ta opredelitev sploh izvedljiva. Nevtralnosti ni mogoče razglasiti, temveč jo je treba $v$ mednarodni skupnosti doseči s pogajanji.
} 
mnenj o vstopu v Nato ${ }^{17}$ je pokazala, da so imeli najboljši dostop do medijev uradni viri $^{18}$, ki so skoraj tričetrtinsko zagovarjali vstop, del pa mu je nasprotoval, kar kaže na mnenjsko neuravnoteženost. Mnenja zagovornikov in nasprotnikov so bila večinoma zbrana rutinsko, res pa je, da pri tem niso bili v privilegiranem položaju ne zagovorniki in ne nasprotniki.

Mediji so sprva zavzeli zelo rezerviran, tudi kritičen, v nekaterih primerih celo odklonilen odnos do slovenskega vključevanja v Nato. Pogosto so nekritično navajali stereotipe in nepravilnosti, odzivanje uradnih virov pa je bilo šibko (Bebler, 2002).

V javnih razpravah je prevladal povsem politični diskurz, kljub številnim poskusom uvajanja bolj strokovnih argumentov. Skoraj nemogoče je bilo razpravljati o Natu kot o politični integraciji ali o njegovem obsežnem civilnem programu, javnost ga je videla kot vojaško organizacijo, zato se je javna razprava ves čas vrtela okoli vojaških vprašanj. Mediji so občasno prevzemali držo nasprotnikov in vztrajno opozarjali na odsotnost javne razprave. V resnici je bilo veliko razprav na vseh ravneh od zapisov oziroma poročanj v medijih do dogodkov na vseh ravneh in lokacijah (občine, društva, združenja), vendar so zagovorniki in nasprotniki večinoma razpravljali drug mimo drugega, vsak na svoji prireditvi.

V delu nevladnih organizacij, civilno-družbenih organizacij in gibanj se je zlasti $\mathrm{v}$ obdobju referendumske javne razprave izoblikoval kritičen pogled na vladne odločitve in ravnanje. Njihovi predstavniki so bili izrazito nenaklonjeni vključitvi v Nato, zagovarjali so drugačen pristop za ureditev nekaterih družbenih, socialnih in varnostih vprašanj. Vprašanje članstva $\mathrm{v}$ Natu so povezovali tudi z vprašanjem militarizacije nekaterih delov družbe (šole, univerze, nekatere občine, ustanove) in zahtevali mirovna območja, ki pomenijo »svobodna območja s protivojnimi aktivnostmi $\ll^{19}$. V tem delu so bili še posebej aktivni študenti nekaterih fakultet.

Malešič meni, da so proces slovenskega včlanjevanja v Nato zaznamovale tudi pogoste menjave vodilnih kadrov v ključnih institucijah. V desetih letih se je menjalo pet vlad, obe ključni ministrstvi (MZZ in MO) sta doživeli številne kadrovske zamenjave $^{20}$, kar se je v tem projektu, ki je že tako užival manj usklajeno politično podporo kot včlanjevanje v EU, kazalo v odsotnosti kontinuitete, izkušenj, v pomanjkanju ustreznih smernic in dokumentov, ne nazadnje tudi načrtnega, usklajenega in celovitega pristopa $\mathrm{k}$ obveščanju javnosti o prednostih in pomanjkljivostih članstva ter udeležbi civilne družbe pri sprejemanju pomembnih varnostno-političnih

\footnotetext{
${ }_{17}$ Poler Kovačičeva (2004) je analizirala poročanje slovenskih dnevnikov o različnih mnenjih glede vstopa $v$ Nato $v$ obdobju pred referendumom (od oktobra 2002 do marca 2003). Zanimajo jo kanali zbiranja in status virov informacij, povezanih s predstavljanji mnenj.

${ }_{18}$ Med uradnimi viri so vladni viri obsegali $31,30 \%$, državnozborski 12,33\%, državni 5,34\%, viri političnih strank $14,91 \%$ in tuji elitni viri 22,46\% (Poler Kovačič 2004, 700).

19 Študenti Fakultete za družbene vede (razen obramboslovcev) in Filozofske fakultete so prostore obeh fakultet razglasili za demilitarizirano ozemlje.

${ }^{20}$ MO je od osamosvojitve do vstopa Slovenije v Nato vodilo osem ministrov (Janša, Kacin, Turnšek, Marinček, Krapež, Demšar, Janša, Grizold). Tudi v Uradu Vlade RS za informiranje je tik pred začetkom referendumske kampanje prišlo do menjave direktorja.
} 
odločitev. Vse to je vodilo do očitnega razkola med stališči politično-uradniške elite in javnosti do članstva ter do skrajno zaostrenih napetosti pri odločanju o tem vprašanju (Malešič, 2002).

Precej očitkov je bilo tudi na komunikacijski program. V interni javnosti so mu očitali, da ni dovolj uspešen, ker ni zagotavljal večinske podpore. V medijih so prevladale ocene, da se je ozaveščanje domače javnosti začelo prepozno in da je bilo preveč propagandistično naravnano. Predstavniki civilne družbe so očitali, da ni bilo pravega dialoga; uradni viri naj ne bi znali ali hoteli predstaviti negativnih strani vključitve oziroma prepričljivo razložiti nekaterih vročih vprašanj (stroški članstva, prisotnost vojaških baz). Vladi so zamerili, da niso bili vključeni v proces obveščanja javnosti. Primerjali so komunikacijska programa v podporo vključevanju v EU in Nato; ker je prvi zagotavljal sodelovanje in delno sofinanciranje projektov nevladnih organizacij, drugi pa ne, je ta obveljal za neverodostojnega.

\section{NAUKI IZ KAMPANJE}

V demokratičnih državah se velike politične odločitve včasih potrjujejo z referendumi. Referendum praviloma uspe le ob visoki podpori državljanov, kar zahteva visoko raven obveščenosti in splošnega razumevanja procesov odločanja. Referendum zahteva pripravo rednega in obsežnega programa komuniciranja, ki poskuša predstaviti vse vidike politične odločitve in njene posledice ter v komunikaciji z javnostmi odgovoriti na vprašanja in dvome ter rešiti dileme. To vodilo je usmerjalo komunikacijska programa za vstop v EU in Nato, ki sta deloma potekala hkrati, zato se nehote ponuja njuna primerjava. Kljub podobnosti med programoma je bilo med njima veliko razlik, tako na institucionalni kot na izvedbeni ravni, kar je vplivalo tudi na izvedbo komunikacijskih dejavnosti.

Program ozaveščanja javnosti o vključevanju v EU je bil sestavni del slovenske pridružitvene strategije. Izvajati se je začel hkrati z začetkom slovenskih pogajanj (marca 1998) in je brez prekinitve trajal sedem let, vse do vstopa Slovenije (maja 2004). V priprave za vstop v EU je bila vgrajena odločitev, da se politična odločitev zanj preveri na referendumu. Program komuniciranja se je deloma financiral iz proračuna, v pomembnem delu pa iz evropskih virov (Phare). Delegacija EU v Sloveniji je s pomočjo partnerjev vodila komplementarni program ozaveščanja javnosti, kar je močno okrepilo vidnost in slišnost sporočil ter prisotnost na terenu. Program se je nadaljeval v nezmanjšanem obsegu tudi po vstopu, spremenili so se le vsebine in poudarki. V programu za EU so imeli dovolj časa, da so postopno gradili vedenje, razumevanje in podporo. Na referendumu je bila podpora vstopu $\mathrm{v}$ EU 89,64-odstotna. Dolgoletne izkušnje in razvita komunikacijska infrastruktura so bili dobra podlaga za poznejše večje in manjše vladne projekte (Serajnik, 2009).

Uresničevanje komunikacijskega programa $\mathrm{v}$ podporo vključevanju $\mathrm{v}$ Nato se je začelo, ko so bile uradne priprave že v polnem teku. Trajal je le dobra tri leta (še enkrat dlje, kot je bilo sprva predvideno), kar je malo glede na obsežnost in 
zahtevnost vsebine v prizadevanjih za doseganje sprememb v razumevanju in oblikovanju stališč državljanov. EU je na institucionalni ravni zagotavljala veliko informacij po številnih komunikacijskih kanalih (komplementarna kampanja, sofinanciranje projektov nevladnih organizacij). Politika Nata je tedaj bila, da države članice in kandidatke same obveščajo svoje javnosti o zavezništvu in sodelovanju z njim. Natov oddelek za javno diplomacijo jim je pomagal z nekaterimi orodji (publikacije, študijski obiski, govorci). Referendum pred vstopom v Nato ni bil predviden, politika se je zanj odločila pozneje, zaradi pritiska javnosti ${ }^{21}$, kar je močno spremenilo predvideni način in oblike komuniciranja. Finančna sredstva za izvedbo Natovega programa so bila nekajkrat manjša od proračuna za podporo vstopu v EU.

Oba programa sta težila $\mathrm{k}$ čim celovitejšemu obveščanju javnosti in spodbujanju javnih razprav v različnih medijih. V programu EU sta bili pomembni dejavnosti izobraževanje in sodelovanje z nevladnimi organizacijami, česar v Natovem programu ni bilo mogoče zagotoviti, saj zanje ni bilo posebnih finančnih sredstev. Tudi sicer so se državljani lažje poosebljali s predvidenimi spremembami, ki naj bi jih prinesel vstop države v EU, kot pa razumeli ali se želeli poglabljati v zapleteno obrambno-varnostno politiko v obdobju velikih geopolitičnih sprememb. V komunikacijskem programu za Nato smo bili zaradi krajšega časa v sklepni fazi kampanje prisiljeni uporabiti tudi nekatere oblike prepričevalne komunikacije. Komunikacijski program je navadno opora politikom pri podajanju argumentov, a so politiki pogosto pričakovali, da bodo komunikatorji zagovarjali politične odločitve. Sploh je bilo v vrstah zagovornikov (pre)malo izurjenih in strokovnih govorcev, če pa so bili, so težko privolili v spolitizirano razpravo, ker v javnosti ni bilo razumevanja za druge, racionalnejše in bolj dolgoročno usmerjene argumente. Mednarodni svetovalci za kampanje navadno svetujejo, da je vredno v kampanje vključiti tudi znane osebnosti, ki pritegnejo pozornost s svojo prepoznavnostjo, tudi simbolnim kapitalom. V Sloveniji se je redko katera znanih osebnosti hotela ukvarjati z Natom; podpora prizadevanjem za vstop je veljala za nepriljubljeno. Zavzeto in obsežno komuniciranje z javnostmi v primeru programa EU je bilo večinoma sprejeto kot dobronamerno, v programu podpore za vstop v Nato pa kot vsiljevanje stališč in argumentov. Slišali smo celo očitke, da se javna sredstva namenjajo za vladno propagando.

Komunikatorji v kampanji smo se spopadali tudi z internimi težavami - s pomanjkanjem usposobljenih komunikatorjev na ravni države in v obrambnem sektorju, $\mathrm{z}$ negotovo politično podporo profesionalnim komunikacijskim pristopom, odsotnostjo skupne vladne komunikacijske politike in pomanjkanjem izkušenj pri načrtovanju ter vodenju tako obsežnih in zapletenih komunikacijskih kampanj. Hkrati pa smo v kampanji pridobili neprecenljive izkušnje, ki smo jih pozneje lahko uporabili v podobnih projektih in jih delili tudi s predstavniki drugih držav, ki so se želeli učiti pri nas. Strnemo jih lahko v pet glavnih ugotovitev oziroma priporočil. V velikih projektih so za uspeh komunikacijskih programov ključni:

\footnotetext{
${ }^{21}$ Slovenija je bila tretja država po Španiji in Madžarski, v kateri so se državljani izrekali na referendumu o vstopu v zavezništvo, in druga (po Madžarski), ki je imela referendum pred vstopom v zvezo (Bebler 2009).
} 
- usklajen komunikacijski pristop sodelujočih akterjev (vsebinsko in organizacijsko poenotenje v kampanji prispeva k verodostojnejšemu nastopu);

- združitev vseh razpoložljivih zmogljivosti in virov, ki prinese prave sinergijske učinke;

- prilagoditev komuniciranja pričakovanjem javnosti (nenehno je treba spremljati odzive javnosti in jih upoštevati);

- zagotovitev različnih komunikacijskih pristopov (odnosi z mediji in oglaševanje niso dovolj, uporabiti je treba vse tehnike in orodja za komunikacijo z različnimi javnostmi ter omogočiti dvosmerno komunikacijo);

- civilna družba mora biti povabljena v javno razpravo (omogočiti je treba čim več možnosti za njeno sodelovanje pri soočenju argumentov in mnenj).

\section{SKLEP}

Predstavljena komunikacijska kampanja je bila skupaj s sorodno kampanjo za podporo vstopu v EU eden prvih večjih komunikacijskih projektov v samostojni Sloveniji. V obeh kampanjah so se kalili mnogi komunikatorji javnega sektorja, njihove izkušnje so koristile pripravljavcem in izvajalcem poznejših nacionalnih kampanj (prevzem evra, predsedovanje Slovenije Svetu EU, uvedba schengenskega režima itn.), imele pa so vpliv tudi na vsakdanjo prakso odnosov z javnostmi.

Kampanja je imela pomemben vpliv na prakso odnosov z javnostmi na $\mathrm{MO}$ in $\mathrm{v}$ SV. Med pripravami so se njuni predstavniki sploh prvič srečali s politično ali javno kampanjo ter z zapletenostjo in vsestranskostjo strateškega načrtovanja odnosov z javnostmi, saj so se doslej bolj posvečali parcialni komunikaciji (npr. odnosi z internimi javnostmi, odnosi z mediji). SV do takrat sploh ni imela samostojnega predstavnika ali službe za odnose z javnostmi. Ta se je izoblikovala tudi na podlagi potreb in izkušenj iz kampanje. Znanje in izkušnje, pridobljene v kampanji, so predstavnikom za odnose z javnostmi obeh institucij pozneje omogočili, da s svojim osebjem pripravlja in vodi manjše kampanje.

Čeprav so množični mediji med ključnimi javnostmi, prek katerih MO in SV dosegata večji del svojih javnosti, je iz kampanje izšlo pomembno spoznanje, da ne gre vedno računati samo na nacionalne medije. Vredno je sodelovati tudi z regionalnimi in lokalnimi, ki imajo dober dostop, predvsem pa velik vpliv na oblikovanje javnega mnenja v lokalnih okoljih. MO in SV še danes dosledno uporabljata ta pristop.

Kampanja je prav tako pokazala, da ni dovolj komunicirati le z mediji, temveč je treba upoštevati še vrsto drugih javnosti, ki oblikujejo javno mnenje, začenši z internimi javnostmi in lokalnimi javnostmi ali civilno družbo, ki se aktivira ob takšni posebni temi. Predstavniki teh javnosti pogosto sprožajo veliko bolj poglobljena in podrobna vprašanja, kot jih mediji. Ta dejstva kažejo na kompleksnost vojaškega okolja, ki zahteva negovanje rednih, strateško načrtovanih in upravljanih odnosov z javnostmi ter nenehno usposabljanje komunikatorjev in drugih predstavnikov MO in SV. Na obsežnost, zahtevnost in raznovrstnost tega okolja namreč radi pozabljamo, 
zato prav primer neke kampanje opozori na mnoštvo vidikov in pristopov, ki jih morajo komunikatorji, pa tudi institucija sama, upoštevati v komunikaciji s svojimi javnostmi.

Kampanja v mednarodni strokovni javnosti ni ostala neopažena - kar nekaj držav, ki se pripravljajo na vključitev v zavezništvo, se še vedno želi podrobneje seznaniti z našimi izkušnjami. Na obiskih v MO in SV lahko dobijo veliko uporabnih informacij in priporočil iz prve roke.

Izkušnje iz kampanje niso pomembne le za komunikatorje, temveč so lahko dober zgled in referenčni okvir za druge izvajalce, pa tudi zanimivo gradivo za študente ali raziskovalce (Serajnik, 2009). Komunikacijske kampanje niso bile pogost predmet proučevanja, raziskovalci pogosteje analizirajo posamezne (predvsem medijske) vidike. Takšni komunikacijski projekti ponujajo še veliko tem za proučevanje, na primer analize objektivnosti diskurza v sporočilih zagovornikov in nasprotnikov, proučevanje oblik komunikacije z interesnimi skupinami in skupinami pritiska ter njihovo učinkovitost, učinke prepričevalne komunikacije ipd.

Tudi praksa vojaških odnosov z javnostmi ponuja precej zanimivih vsebin za poglobljeno raziskovanje, na primer o vlogi, vplivih in učinkih internega komuniciranja, o odnosih oboroženih sil z lokalnimi skupnostmi, o kampanjah v podporo naboru novih kadrov, o komunikaciji oboroženih sil ob sodelovanju na misijah, o komunikaciji z domačimi in tujimi mediji ob udeležbi v vojaških operacijah zavezništva, o izgradnji svojih komunikacijskih kompetenc in zmogljivosti, o oblikah in učinkih kriznega komuniciranja ipd. Ker slovenska literatura odnosov z javnostmi in tudi obramboslovja skoraj ne obravnava teh tem, ponuja tokratna izdaja revije Sodobni vojaški izzivi, ki svoj prostor namenja izzivom odnosov z javnostmi na vojaško-obrambnem področju, dobro priložnost za začetek polnjenja te vrzeli.

1. Bebler, A., 2009. Pot Slovenije v Nato. Slovenia's Road to Nato. Bilten Slovenske vojske, 11 (3), str. 105-17. Ljubljana: Znanstveno strokovna publikacija Slovenske vojske.

2. Bebler, A., 2002. Na rob razprave o morebitnem članstvu Republike Slovenije v Natu. Teorija in praksa 39/3, str. 402-413.

3. Bric, R., 2008. Specifični vidiki v komuniciranju med oboroženimi silami in javnostmi. Teorija in praksa 45/6, str. 706-727.

4. Cutlip, M. S., Center, A. in Broom, G., 1994. Effective public relations (7th ed.). Englewood Cliffs, NJ: Prentice Hall.

5. Dokumenti, analize, zapiski, načrti in evalvacije-januar 2001-maj 2004. Arhiv Urada Vlade RS za komuniciranje.

6. Dozier, D., Grunig, L. A., Grunig, J. E., 2001. Public Relations as Communication Campaign. V Rice, Ronald E., Atkin, Charles K.: Public Communication Campaigns. 3rd edition. Thousand Oaks, London, New Delhi: Sage Publications.

7. Hiebert, R. E., 2003. Public relations and propaganda in framing the Iraq war: a preliminary review. Public Relations Review 29, str. 243-255.

8. Komunikacijska strategija v podporo vključevanju Slovenije v Nato, Urad Vlade RS za informiranje, Ljubljana, april 2001, dostopno na http:// nato.gov.si. 
9. Malešič, M., 2002. Slovenska javnost, politično-uradniška elita in Nato. Teorija in praksa 39/3, str. 414-425.

10. Nacionalna strategija RS za vstop v Nato. Dostopno na http://nato.gov.si/slo/dokumenti/ nacionalna-strategija.pdf. Maj 2013.

11. Obveščanje domače in tuje javnosti o vključevanju Slovenije v Nato. Arhiv Urada vlade RS za komuniciranje. Dostopno na http://www.ukom.gov.si/fileadmin/ukom.gov. si/pageuploads/dokumenti/arhiv_projektov/_Obvescanje_javnosti_o_vkljucevanju_ Slovenije_v_NATO_2001-_2003.pdf, maj $20 \overline{13}$.

12. Poler Kovačič, M., 2004. Novinarska rutina in (pre)moč uradnih virov informacij. Teorija in praksa 41, 3/4, str. 690-702.

13. Politbarometer: Javnomnenjske raziskave o odnosu javnosti do aktualnih razmer in dogajanj v Sloveniji. Arhiv raziskav. Dostopno na http://www.cjm.si/arhiv_pb.

14. Prezelj, I., 1997. Komuniciranje med oboroženimi silami in javnostmi. Teorija in praksa 34/6, str. 1010-1034

15. Serajnik Sraka, N., in Vidrih, B., 2001. Vladni odnosi z javnostmi: model organiziranosti vladnih odnosov z javnostmi v Sloveniji. Teorija in praksa 38/4, str. 650-674.

16. Serajnik Sraka, N., 2009. Komunikacijska kampanja. Priročnik za načrtovanje, vodenje in ocenjevanje komunikacijskih kampanj. PR Zbirka. Ljubljana: GV Založba.

17. Slovensko javno mnenje, 2002. Primerjalni podatki povezani z odnosom slovenske javnosti do Nata v letih 1999 in 2001. Obramboslovni raziskovalni center, Inštitut za družbene vede Univerze v Ljubljani. Dostopno na http://nato.gov.si/slo/javno-mnenje/ varnost/podatki-varnost/.

18. Smith, M. F., 2005. Warfare and Public Relations. V Heath, Robert L., ur. Encyclopedia of Public Relations. Volume 2, str. 893-897. Thousand Oaks: Sage Publication.

19. Strömbäck, J., in Kiousis, S. 2011. Political Public Relations. Principles and Applications. New York, London: Routledge.

20. Toledano, M., 2010. Military Spokespeople and Democracy: Perspectives from Two Israeli Wars. V Heath, Robert L., ur. The Sage Handbook of Public Relations. Second Edition, str. 585-599. Thousand Oaks: Sage Publications.

21. Van Dyke, M. A., in Verčič, D., 2009. Public relations, public diplomacy and strategic communication: An international model of conceptual convergence. V The Global Public Relations Handbook, Revised and Expanded Edition: Theory, Research, and Practice, ur. Krisnamurthy Sriramesh in Dejan Verčič, str. 822-842. New York: Routledge.

22. Vreg, F., 2000. Politično komuniciranje in prepričevanje. Komunikacijska strategija, diskurzi, preprčievalni modeli, propaganda, politični marketing, volilna kampanja. Ljubljana: Fakulteta za družbene vede.

23. Spletno mesto Slovenija in Nato - http:// nato.gov.si

\section{Zahvala}

Avtorica se zahvaljuje Alešu Sili, vodji Službe za strateško komuniciranje na Ministrstvu za obrambo in tesnemu sodelavcu v komunikacijskem programu za podporo vstopu Slovenije v Nato, za pripombe in dopolnila v prispevku. 



\section{DRUŽBENA OMREŽJA KOT IZZIV KOMUNICIRANJA V SLOVENSKI VOJSKI}

\section{SOCIAL NETWORKS AS A CHALLENGE OF COMMUNICATION IN THE SLOVENIAN ARMED FORCES}

Povzetek Slovenska vojska je na družbenih omrežjih aktivna od januarja 2013. Od takrat je naredila velik korak v komuniciranju znotraj tako imenovanih novih medijev, vendar še ne dosega ravni in načina komuniciranja zavezniških držav. Zato bo morala še veliko napora usmeriti $\mathrm{v}$ oblikovanje strategije komuniciranja znotraj družbenih omrežij, da bo izkoristila moč in doseg takšnega načina komuniciranja z javnostjo. Članek z analizo polletnega komuniciranja Slovenske vojske na družbenih omrežjih in s predstavitvijo dveh študij primerov, narejenih na ravni nemške vojske in Nata, potrjuje prej navedeno. Rezultati so pokazali, da je razvita komunikacijska strategija dobra, da s komuniciranjem prek družbenih omrežij Slovenska vojska bogato dopolnjuje svojo strategijo odnosov z javnostmi, da se predstavlja še bolj pregledno in da vedno bolj aktivno sodeluje z zainteresiranimi javnostmi. Najboljše komunikacijske rezultate dosega na Facebooku, medtem ko je v razvoju drugih omrežij, pridobivanju zaupanja organizacije in njenih zaposlenih v socialne medije ter v oblikovanju organizacijske kulture komuniciranja na teh ravneh še veliko dela, ki ga je treba opraviti. Pri tem ne smemo pozabiti, da je treba vse aktivnosti Slovenske vojske na družbenih omrežjih vnaprej in načrtno ter skladno z načrtovano celostno podobo organizacije v javnosti razvijati do podrobnosti in hkrati aktivno slediti novim težnjam in aktivnemu dialogu $\mathrm{z}$ javnostmi.

Ključne besede

Abstract The Slovenian Armed Forces has become actively involved in social networks in January 2013. Since then, it has taken a major step in the communication within the so-called new media; however, it has still not attained the level and mode of communication of other allied countries. Much effort will thus have to be devoted to the development of a communication strategy within social networks in order to make use of the power and reach of such a public communication method. The article 
supports the above-mentioned facts with the analysis of six-month social network communication activities of the Slovenian Armed Forces and the presentation of two case studies carried out at in the German Armed Forces and NATO. The results have shown that the developed communication strategy was good; that Slovenian Armed Forces' communication activities through social networks represent a rich complement to its public affairs strategy; that such activities aid to its transparent presentation, and that its involvement with the interested public is becoming increasingly active. The best communication results have been achieved on Facebook, while there is still much to be done in the development of other networks, in building trust in social media within the organization and its employees, and in creating an organizational culture of communication at these levels. In so doing, one must not forget that all Slovenian Armed Forces' social networks activities should be thoroughly developed in advance and in a premeditated manner as well as in accordance with the planned corporate public image of the organization. At the same time, it should actively follow new trends and active dialogue with the public.

\section{Key words Social networks, Slovenian Armed Forces, communication analysis, case study.}

Uvod Komuniciranje z javnostmi je pomembno za vsako organizacijo, a danes le s tradicionalnim komuniciranjem prek sporočil za medije uspeh ni več zagotovljen. Pojmi, kot so novi mediji, družbena omrežja, sledilci, elektronsko poslovanje in Web 2.0, vse bolj stopajo v ospredje in omogočajo neposredno komunikacijo z javnostmi povsod po svetu, v realnem času, znotraj neprekinjenega časovnega cikla 24 ur na dan in vse dni v tednu (24/7). Danes ni več vprašanje, ali sodelovati, temveč le še, v kakšnem obsegu in kako ter znotraj kakšnih meja. To potrjujejo tudi številke.

Vsak dan se več milijonov ljudi po vsem svetu vpiše na svoj profil na Facebooku, ki ima od ustanovitve do danes že več kot milijardo aktivnih uporabnikov. ${ }^{1}$ Decembra 2012 je Twitter uporabljalo že več kot 200 milijonov ljudi po svetu, z razvojem mobilnega internetnega dostopa pa se omrežje vse boj širi. v primerjavi z zdajšnjih 6,1 milijarde dolarjev, ki se vsako leto porabijo za oglaševanje na družbenih medijih, so predvidevanja, da bo leta 2016 za oglaševanje na tem kanalu porabljenih kar 11 milijard dolarjev. ${ }^{2}$ Youtube, ki je na voljo kar v 43 različnih jezikih, je druga najbolj obiskana spletna stran svetovnega spleta, takoj za Googlom, na njem se vsako minuto dneva nalaga nova video vsebina. ${ }^{3}$ Tudi v Sloveniji so številke zgovorne, po navedbah statističnega urada in spletne strani Socialbakers je v Sloveniji 65

\footnotetext{
Oktobra 2013 se je vsak dan vpisalo v svoj profil na Facebooku kar 618 milijonov uporabnikov. Venem dnevu! (http://tumblr.webbyawards.com/post/57534184521/a-brief-history-of-social-advertising).

2 Za primerjavo je bilo v svetu leta 2012 za oglaševanje v tiskanih medijih porabljenih 38,8 milijarde dolarjev, za oglaševanje na TV pa 64,8 milijarde. Številke so sicer bistveno večje kot pri oglaševanju prek družbenih omrežij, vendar je zanimiva primerjava ocene, kakšna bo poraba leta 2016, ki kaže na to, da bo za tiskano oglaševanje poraba manjša za šest milijard dolarjev, za TV-oglaševanje se bo povečala za okoli $11 \%$, medtem ko se bodo stroški oglaševanja prek družbenih medijev najmanj podvojili in bodo skupaj z drugim oglaševanjem prek spleta dosegli stroške TV-oglaševanja (http://www.go-gulf.com/blog/online-ad-spending/).

3 Vsi vodstavku navedeni podatki so povzeti po http://tumblr.webbyawards.com/post/57534184521/a-briefhistory-of-social-advertising
} 
odstotkov prebivalstva, ki so aktivni na internetu (v številkah to pomeni 1,3 milijona Slovencev), skoraj enak odstotek uporabnikov pa se je tudi že kdaj srečal z družbenimi omrežji. Sredi februarja 2013 je bilo v Sloveniji 748.200 uporabnikov Facebooka.

Tudi Slovenska vojska se zaveda pomembnosti družbenih omrežij, vendar je šele na začetku aktivnega vključevanja in komuniciranja s svojimi javnostmi prek tega medija. Čeprav je že dolgo aktivna na medmrežju ${ }^{4}$, se je šele v začetku letošnjega leta začela intenzivno vključevati v družbena omrežja. Po polletnem aktivnem komuniciranju so rezultati že vidni, a je to področje tisto, ki ga mora SV v okviru odnosov z javnostmi še naprej intenzivno razvijati in ga zgraditi kot samostojno vejo komuniciranja znotraj komunikacijske strategije organizacije.

Namen članka je preveriti, ali je SV na pravi poti v komuniciranju prek socialnih omrežij, da z njimi dovolj uspešno dopolnjuje organizacijsko strategijo in politiko komuniciranja z javnostmi ter ohranjanja želeno podobo »znamke« SV znotraj ciljne populacije, in ali je skladna tudi s politiko zavezništva na tem področju ali morda zaostaja za njo.

Po splošni opredelitvi pojmov za razumevanje družbenih omrežij in izzivov ter razvojnih možnosti, ki jih prinašajo s seboj, bo glavni poudarek na predstavitvi komunikacijske strategije SV prek družbenih omrežij in na treh študijah primera. Primer vključevanja SV bo kot del dobro načrtovane komunikacijske strategije predstavljen $\mathrm{z}$ analizo polletnega komuniciranja prek omrežij, pregled primerljivosti z aktivnostmi nemških oboroženih sil in Nata na področju tako imenovanih novih medijev pa z analizo že opravljenih študij teh dveh subjektov. S primerjavo vseh ugotovitev empiričnega dela članka pa bi želeli na koncu ugotoviti, kako uspešna je lahko udeležba varnostne organizacije, kot je SV, znotraj okvirov Web 2.0, in izpostaviti pozitivne in negativne strani delovanja ter najti različne predloge za izboljšavo strategije komuniciranja znotraj izpostavljenih omrežij.

\section{KOMUNIKACIJSKI IZZIVI DRUŽBENIH OMREŽIJ}

\subsection{Metodologija proučevanja družbenih omrežij}

Strategija in učinkovitost komuniciranja SV prek družbenih omrežij bosta v članku predstavljeni s študijo primera »delovanja SV na družbenih omrežjih«, ki bo poskušala najti natančne odgovore na vprašanja: kaj so družbena omrežja in katere so njihove pasti z vidika uporabe v vojaški organizaciji; ali so ti mediji uporabni vedno in za vsako vrsto komuniciranja; ali z njimi dosegamo želene ciljne javnosti; kaj in kako komunicirati znotraj postavljenih okvirov komunikacijske strategije; ali lahko sporočilo SV za javnost spravimo v tvit, dolg le 140 znakov; kakšna je strategija komuniciranja SV na družbenih omrežjih in kaj je mogoče v prihodnosti izboljšati, nadgraditi ali spremeniti.

4 Do januarja 2013 je komuniciranje SV prek svetovnega spleta potekalo na spletni strani SV www.slovenskavojska. si, prek spletne strani www.postanivojak.si in na Youtubu prek TV-studia Ministrstva za obrambo v Poljčah. 
Primerljivost strategije komuniciranja SV in njenih rezultatov na omrežjih z Natovo strategijo bo v članku analizirana s sklicevanjem na dva članka, v katerih sta objavljeni študiji primera Natove politike komuniciranja $\mathrm{v}$ družbenih omrežjih in modela komuniciranja nemške vojske znotraj novih medijev. ${ }^{5}$ Po obravnavi študij bo narejena primerjalna tabela, ki bo omogočila primerjavo komuniciranja treh proučevanih institucij in iskanje podobnosti s SV.

Za boljše razumevanje pojmov in ugotovitev, uporabljenih v raziskovalnem delu, bodo v nadaljevanju predstavljeni ključni pojmi in opredelitve socialnih omrežij, da uporaba različnih terminov, povezanih z obravnavano temo, ne bo vzbujala dvomov ali povzročala nerazumevanja.

\subsection{Kaj so družbena omrežja}

Bradley in McDonald v svoji publikaciji (2011, str. 10) opredelita družbene medije kot virtualno okolje, ki je ustvarjeno za množično družbeno povezovanje, in interaktivni dialog, omogočen prek interneta ali mobilne tehnologije.

Tradicionalno enosmerno komuniciranje prek tiskanih oziroma branih medijev se je v primeru družbenih omrežij umaknilo množičnemu komunikacijskemu modelu, ki presega tudi dvostransko komunikacijo. Iz informacijske dobe prestopamo v dobo družbene uporabe internetnih zmogljivosti. Vse to obsega izraz Web 2.0, preveden v slovenščino Splet 2.0.

Ta izraz se uporablja že od leta 2004, ko so ga v založniški hiši O'Reilly Media uporabili za naslov niza seminarjev na temo druge generacije spletnih storitev, ki uporabnikom omogočajo spletno sodelovanje in delitev informacij (Suhadolc, 2007, str. 22). Nova medijska orodja, ki so značilna za Splet 2.0, omogočajo sodelovanje uporabnikov in delitev informacij v realnem času. Vse to je omogočilo, da je internet postajal vse bolj odprt in prilagodljiv prostor za izražanje. Poleg klasičnih oblik internetnega komuniciranja (spletne strani, e-sporočila) so se pojavila še družbena omrežja (angl. social media). To je izraz za vsebine, ki jih z uporabo spletnih orodij ustvarjajo uporabniki spleta za objavo svojih vsebin, mnenj, izkušenj itn. Družbena omrežja so premik v načinu, kako ljudje odkrivajo in berejo različne vsebine (novice, informacije ipd.) ter jih delijo $\mathrm{z}$ drugimi.

Izraz družbena omrežja je zelo širok in združuje najrazličnejše oblike, tehnologije, orodja, aplikacije znotraj digitalnih medijev. Strokovna javnost jih deli na šest temeljnih vrst: spletna družbena omrežja - Facebook, MySpace, spletni dnevniki (blogi), Wikipedija (vikiji, strežniški program, ki uporabnikom omogoča prosto ustvarjanje in urejanje spletnih strani s spletnim brskalnikom), Youtube, Flickr (podcasting, programi, ki omogočajo objavljanje digitalnih vsebin, ki jih je mogoče s spleta v obliki avdio ali video datotek prenašati na računalnik ali prenosno napravo), spletni forumi (pisna izmenjava mnenj o neki tematiki) in Twitter (mikrobloganje,

5 Prvi članek: Leiderman, L., 2012. Policy making in 140 characters or less: NATO and social media; drugi: Jacobs, J., Diefenbach, V., 2012. The Use of Social Media in Public Affairs - A German Perspective. 
status up date ali po slovensko sprememba statusa v največ 140 znakih) (Mayfield, 2008, str. 6).

\subsection{Strahovi pri uporabi družbenih omrežij}

V poplavi informacij in možnosti vsestranskega komuniciranja je nemogoče zadržati informacije zase, tako da po tem ali onem kanalu pogosto pridejo v javnost. Vendar se je zaradi pasti in varnostnih zadržkov pri uporabi družbenih omrežij nesmiselno od njih ograditi in je najbolj modro, da se varnostna organizacija, kot je SV, sooči z morebitnimi težavami in se na virtualno družbeno komuniciranje temeljito pripravi.

Namesto hitenja in brezglavega iskanja novih sledilcev je treba oblikovati dobro politiko in strategijo delovanja na novih omrežjih, določiti ciljne javnosti in namen komuniciranja, zgraditi organizacijsko kulturo ter pripraviti koncept kriznega komuniciranja, če bi bilo kaj narobe.

Največji izzivi v sodelovanju na družbenih omrežjih so zaščita varnostno občutljivih podatkov, ${ }^{6}$ zapletenost procesov vojaške organizacije, ki jih je treba spraviti na raven splošnega družbenega razumevanja, in to, da bi lahko ob intenzivnem komuniciranju prek družbenih omrežij služba, ki skrbi za odnose z javnostmi, postala prizivna služba za vse, kar se zgodi v organizaciji (Jacobs, 2012, str. 5-8).

\section{UPORABA DRUŽBENIH OMREŽIJ V SLOVENSKI VOJSKI}

Študija primera komuniciranja SV na različnih družbenih omrežjih bo narejena na podlagi predstavitve strategije komuniciranja na novih medijih, v kateri je predstavljeno, zakaj se je SV odločila sodelovati, katere so ciljne javnosti, kaj je glavni namen takšnega komuniciranja in kako bosta opravljeni analizi zadovoljstva vključenih javnosti in doseganja osnovnega namena komuniciranja. Po predstavitvi strategije se študija osredotoči na statistično in vsebinsko analizo aktivnosti in komunikacije na posameznih družbenih omrežjih, od Facebooka do Flickerja. Kot orodje bodo uporabljene internetne aplikacije ${ }^{7}$, ki omogočajo numerično spremljanje trendov in uspešnosti na posameznih medijih, ter kvalitativna analiza odziva in razvite komunikacije uporabnikov posamičnih družbenih mrež.

\subsection{Strategija komuniciranja}

Za uspešno komuniciranje $\mathrm{v}$ času novih medijev je nujno proaktivno načrtovanje z dobro komunikacijsko strategijo, ki se bo ukvarjala z različnimi javnostmi prek različnih medijev, od tradicionalnih do spletnih in družbenih omrežij, ter omogočala neprekinjen informacijski tok in večsmerno komunikacijo (Žbogar, 2012, str. 21).

\footnotetext{
Sicer se varnostni zadržki in tveganja pojavljajo pri vseh uporabnikih družbenih omrežij, a je to pri varnostni organizaciji, kot je vojaška, še posebnega pomena prav zaradi narave podatkov, pogosto zaupnih, ki jih upravlja.

Analizo strani SV na Facebooku prek FB Insights, Twitter in Youtube prek osebne vizitke, Blogger prek podprograma, ki statistično beleži aktivnosti uporabnikov na blogu, ipd. Poleg teh orodij bo uporabljena tudi statistika spletne strani, ki spremlja aktivnosti na družbenih omrežjih Socialbakers (http://analytics. socialbakers.com).
} 
Preden je SV januarja 2013 intenzivno stopila na pot komuniciranja prek družbenih omrežij, je skladno z Natovimi navodili o odnosih z javnostmi in prej navedenim izoblikovala strategijo komuniciranja na teh omrežjih. Pri njenem oblikovanju si je pomagala s teorijo Marcela Berneta (2010, str. 79), ki trdi, da je za dober začetek komuniciranja prek družbenih omrežij treba poiskati odgovore na vseh osem vprašanj, navedenih v nadaljevanju. SV jih je našla. ${ }^{8}$

\section{Kaj je namen komuniciranja organizacije prek družbenih omrežij?}

Skladno z Natovo politiko odnosov z javnostmi in upoštevanjem novih komunikacijskih tokov je tudi SV prepoznala sodelovanje v družbenih omrežjih kot enega izmed svojih komunikacijskih ciljev. Namen takšnega komuniciranja je v vzpostavitvi večsmerne komunikacije in posredovanju informacij prek informacijskega kanala, ki ga v vsakdanjem življenju uporablja že omenjenih več kot 70 odstotkov izbrane ciljne populacije. Osnovni cilji komuniciranja SV na družbenih omrežjih so ohranjanje pozitivne sprejetosti »blagovne znamke Slovenska vojska«, zavedanje o nujnosti njenega obstoja in vsesplošna družbena podpora, izražena med splošno slovensko javnostjo ter mnenjskimi in lobističnimi skupinami.

\section{S kom želi SV komunicirati prek družbenih omrežij, katere so ciljne javnosti?}

Kot poklicna prostovoljna vojska je SV svojo ciljno populacijo, s katero bi predvsem želela komunicirati prek družbenih omrežij, prepoznala v krogu mladih med 16. in 30. letom, ki so morebitni kandidati za zaposlitev. Prav tako želi z aktivnostmi na socialnih omrežjih aktivirati skupino javnosti, ki jo je opredelila kot notranjo in vključuje vojake (vsi zaposleni v SV) in njihove družinske člane ter prijatelje, ki jih želi informirati. Kljub jasno določenim ciljnim skupinam pa želi SV v svojo strategijo komuniciranja vključevati tudi splošno slovensko javnost, saj je od davkoplačevalcev najbolj odvisno, ali odobravajo njen obstoj in ali jo podpirajo.

\section{Kakšne informacije lahko organizacija ponudi v omrežje?}

»On line « informacije oziroma komuniciranje SV mora biti v vsakem pogledu relevantno, verodostojno, neprekinjeno in ob pravem času. Vsebina in oblika informacij morata biti prilagojeni vsaki posamezni vrsti družbenega omrežja ter ciljni populaciji posebej, hkrati morata biti skladni (usklajeni) s politiko komuniciranja na ravni organizacije. Za objavo na družbenih omrežjih so primerne prav vse informacije, ki so namenjene objavi v tiskanih, zvočnih in TV-medijih, le da jim je treba poiskati primerna obliko in način podajanja.

\section{Kako komunicirati s sodelujočimi javnostmi?}

Komuniciranje (informiranje, poslušanje in odzivanje) s sodelujočimi javnostmi na družbenih omrežjih mora postati vsakdanja spretnost znotraj sektorja za odnose z javnostmi v SV. Vsak dan je treba objavljati informacije, spremljati odzive in odgovarjati nanje z ustreznimi in preverjenimi odgovori. Za boljšo organiziranost nenehnega spremljanja dogajanja na družbenih omrežjih je treba hierarhično razdeliti

8 Podobno kot Nemška vojska (Jacobs, 2012, str. 5-11). 
administrativne vloge ter usposobiti kader, da bo sposoben samostojnega odzivanja na vsakodnevno dogajanje znotraj omrežij, predvsem odzivanja na napake.

\section{Kako zagotoviti dialog med uporabnikom in akterjem?}

SV je za komuniciranje predvidela komunikatorja družbenih omrežij, ki ima pooblastila za strokovno komuniciranje in se ob podpori štaba odziva na vprašanja in razprave uporabnikov. Ob kriznih dogodkih in težjih razpravah se v komuniciranje, skladno s strukturo vodenja in poveljevanja, vključi tudi predstavnik za odnose $\mathrm{z}$ javnostmi, da se tok informacij ne prekine.

\section{Kako se vključuje strategija komuniciranja prek družbenih omrežij v celostno ko- munikacijsko strategijo organizacije?}

Skladno z Direktivo za organiziranje in izvajanje komuniciranja z javnostmi ima SV pripravljeno tudi celoletno strategijo, znotraj katere so umeščeni tudi načini in oblike komuniciranja na družbenih omrežjih. Končni cilji usklajene strategije so pozitivna celostna podoba organizacije, doseganje skupnih organizacijskih ciljev in povezovanje komuniciranja v vseh medijih (od tradicionalnih prek interneta do družbenih omrežij). To je mogoče le ob dobro usklajenem medijskem načrtu in dobri promociji organizacije na družbenih omrežjih (tudi obratno), pri čemer je treba poudariti tudi pomen obveščanja notranje javnosti o aktivnostih na teh omrežjih, saj se bo najprej prek nje širil »dober glas«.

\section{Kako razporediti vire upravljanja socialnih mrež?}

Kadrovsko in finančno na začetku takšno komuniciranje ni obremenjujoče za organizacijo, saj je mogoče z majhnim, a intenzivnim vložkom doseči velik učinek, kar je razvidno tudi iz analize v nadaljevanju. Vendar bo treba tudi znotraj SV v komunikacijski strategiji načrtovati povečanje zmogljivosti, predvsem povečanje kadra, s katerim bi zagotavljali večsmerno komuniciranje znotraj neprekinjenega informacijskega toka, povečati pa bi bilo treba tudi sredstva in izboljšati tehniko, kar bi omogočilo povečanje prepoznavnosti SV na omrežjih.

\section{Kako meriti učinkovitost in uspešnost komuniciranja?}

V začetni fazi je SV za svoj ocenjevalni aparat izbrala čitalnike aktivnosti in komunikacije, ki dajejo statistične podatke skoraj vsak dan, so brezplačni in so navadno sestavni del posameznega družbenega medija. Poleg tega je za svojo metodo ocene uspešnosti izbrala analizo dialogov oziroma večsmernih izmenjav informacij. Širša analiza se opravlja vsak dan, poglobljena pa vsake pol leta in ob kakšni večji PRkampanji. Za podrobnejšo analizo komunikacije v prihodnje bi morali biti s strategijo predvideni tudi izdatki za nakup programske opreme, ki bi omogočila primerjalno analizo uspešnosti.

SV s svojo strategijo komuniciranja na družbenih omrežjih deluje po načelu »learning by doing«, saj se zaveda dejstva, da je na pot novih medijev stopila razmeroma pozno in mora po pripravi dobre strategije, ki je temelj, z aktivnim vključevanjem 
v družbena omrežja šele zgraditi ter dopolniti svojo politiko in pravila delovanja znotraj te vrste komuniciranja.

\subsection{Analiza družbenih omrežij Slovenske vojske}

SV je trenutno aktivna na petih različnih družbenih omrežjih, najbolj na Facebooku, ki mu sledita Twitter in Youtube. Analiza posameznih družbenih medijev bo omogočila končno primerjavo uspešnosti komuniciranja na njih in primerjavo z zavezniškimi strukturami, dala bo tudi odgovore na vprašanja, ki se pojavljajo ob nadaljnjem načrtovanju politike komuniciranja prek družbenih omrežij.

\section{Facebook}

Po podatkih ${ }^{9}$ ima vsak tretji Slovenec svoj profil na Facebooku (760.000), največ uporabnikov je med 18. in 44. letom starosti (560.000), kar je tudi glavna ciljna populacija komuniciranja SV. Zaradi tega je SV na tem omrežju tudi najbolj aktivna in dosega najboljše rezultate. V opazovanem obdobju, to je od januarja do julija 2013, je bilo skupno zbranih že več kot 4500 »všečkov« strani Slovenska vojska (Slovenian Armed Forces). Povprečno se na strani vsak dan ustavi 14.000 oseb, aktivno pa se jih komuniciranja udeležuje več kot 700 (največ jih je aktivno sodelovalo več kot 4000, takrat z dosegom več kot 140.000). Stran na Facebooku se uporablja kot neformalni vir komuniciranja, $\mathrm{s}$ katerim organizacija gradi svojo podobo $\mathrm{s}$ foto in video zgodbami, oblikovanjem dogodkov in kratkih sporočil, s katerimi želi ustvariti smiseln dialog s svojimi ciljnimi javnostmi, z državljankami in državljani Slovenije ter drugimi sledilci. Kvalitativna analiza komuniciranja (komentarji, objave na zidu SV in sporočila v zasebni pošti) na tem družbenem omrežju pokaže, da SV tu spremljajo predvsem tisti, ki jih ta zanima tako ali drugače, zelo malo pa je takšnih sledilcev, ki želijo širiti negativna sporočila o njej. Največ zanimanja je za video vsebine, nagradne igre in foto zgodbe $\mathrm{z}$ misij.

Prikaz števila ljudi, ki so junija 2013 aktivno sledili SV in komunicirali z njo prek strani na Facebooku

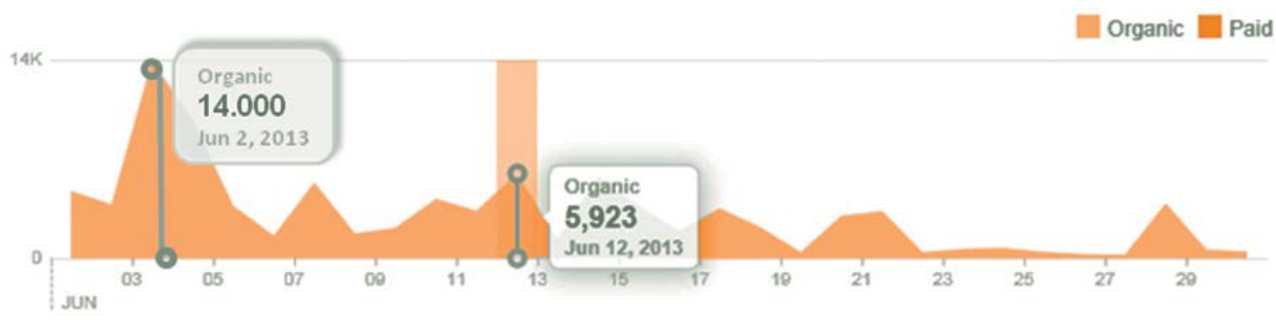

Vir: https://www.facebook.com/pages/Slovenska-vojskaSlovenian-Armed-Forces/.

9 Vsi podatki so pridobljeni na spletni strani: https://www.facebook.com/ads/create/. 
Z grafa lahko razberemo, kakšne so mesečne aktivnosti zainteresiranih javnosti na strani SV na Facebooku, kar je odvisno predvsem od aktivnosti SV in njenega komuniciranja prek družbenih medijev. Osrednja vaja SV se je začela 2. junija 2013, kar jasno sovpada $\mathrm{z}$ izrednim povečanjem zanimanja za dogajanje $\mathrm{v}$ SV, medtem ko z grafa lahko razberemo precej manj aktivnosti med 23. in 27. junijem, ko se je vaja končala in ni bilo veliko drugih aktivnosti. Podoben vzorec lahko opazimo v vseh mesecih - ko se pojavi objava zanimivega ali večjega dogodka, število aktivnih naraste, v vmesnem času obiskuje stran od 4000 do 6000 sledilcev, ko je aktivnosti manj, pa številka pade pod 1000 na dan.

\section{Twitter}

Po oceni Sitwitta je v Sloveniji 35.000 uporabnikov Twitterja, nekateri ob »tvitanju« preživijo tudi po tri ure na dan. Omrežje omogoča najhitrejše posredovanje kratkih informacij in sporočil do uporabnika in nazaj. Tega SV še ne izkorišča dovolj, kot so opazili že nekateri drugi pisci ${ }^{10}$, uporablja ga bolj kot oglasno desko in ne kot vir dvosmernega komuniciranja. To bo v prihodnje seveda treba upoštevati in prilagoditi strategijo komuniciranja, pa tudi tehniko in mobilni internetni dostop do tega družbenega kanala. Primer dobre prakse, ki bi ji SV lahko sledila, bi lahko našli pri Policiji (@policija_si).11

Kljub temu pa trenutno stanje na@slovenskavojska (247 sledilcev, 304 sporočila in več kot 200 omemb, delitev in pogovorov) nikakor ni slabo. Analiza sporočil na »mikroblogu« pokaže, da je med sledilci in komentatorji kar nekaj takšnih, ki prek kratkih sporočil izražajo svoje nestrinjanje z nekaterimi oblikami delovanja SV. Ravno zaradi tega bi morali pospešeno zgraditi učinkovito strategijo delovanja in odzivanja na tem omrežju, ker bi to zagotovo veliko prispevalo k oblikovanju podobe SV v javnosti in tudi k pridobivanju povratne informacije o tem, kako SV v nekem trenutku vidijo splošna javnost, mediji in drugi.

\section{Youtube}

$\mathrm{Na}$ kanalu, na katerem se vsak dan zavrti več kot tri milijarde video posnetkov in je nanj vsako minuto naložen nov video klip, ima SV 55 sledilcev in 36 video posnetkov, ki si jih je ogledalo skoraj 10.000 uporabnikov interneta. Čeprav medij spremlja solidna številka naročnikov, lahko ob analizi komuniciranja prek družbenih omrežij ugotavljamo, da si video posnetke, objavljene na Facebooku, ogleda vsaj za polovico več uporabnikov, zato bo treba na tem omrežju uvesti še kakšno novost in pospešiti tudi produkcijo kratkih filmov, ki bi bili predvsem aktualni (z minimalnim časovnim zamikom med dogodkom in objavo).

Ob kvalitativni analizi tega medija lahko ugotovimo, da je manjše zanimanje za kanal SV na Youtubu tudi posledica tega, da ima TV-studio MO, ki skrbi za video

\footnotetext{
${ }^{10}$ Npr. Jure Brankovič v julijski številki revije Obramba (Brankovič, Jure, 2013. Smo res zaslužili 1,08 milijona? Revija Obramba, letnik 45, julij 2013, str. 10.)

${ }^{\prime \prime}$ @policija si je Twitterjev račun slovenske Policije, ki je kot varnostna organizacija najbolj primerljiva s SV in zato v članku omenjena kot primer dobre prakse, ki bi mu bilo dobro slediti. Policija ima na svojem računu že 5277 sledilcev, ima sicer le 248 tvitov, a je zelo intenzivna v komunikacijah s svojimi sledilci.
} 
produkcijo na ministrstvu in $\mathrm{SV}^{12}$, prav tako svoj kanal, na katerem objavlja filme o SV in je zato bolj prepoznan med ciljnimi javnostmi.

\section{Blogger}

Blog je spletna stran, ki se uporablja kot spletni dnevnik oziroma e-dnevnik, na katerem avtor občasno prikazuje besedila, slike in druge elemente. Z več kot 13.000 ogledi, tremi podstranmi in več kot petdesetimi objavami v pol leta je komuniciranje prek tega družbenega omrežja nad pričakovanji. Največji uspeh je bil dosežen z objavljanjem spletnega dnevnika Pisma iz peskovnika ${ }^{13}$, na katerega vsak petek čaka več kot dvesto stalnih bralcev.

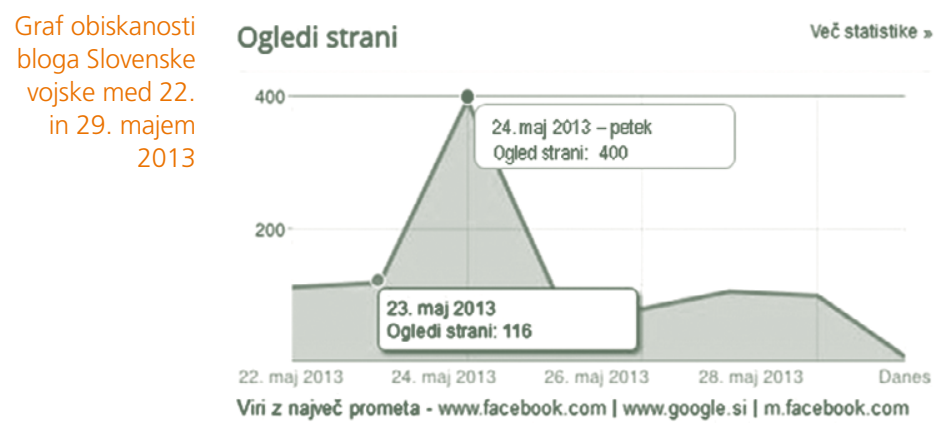

Vir: http://draft.blogger.com/blogger.g?blogID=3539453150830008285\#overviewstats.

Kot je vidno z grafa, je povprečna dnevna obiskanost bloga SV nekaj več kot 100 bralcev, ob petkih pa se obiskanost strani poveča tudi za štirikrat.

A tudi na tem omrežju po analizi lahko ugotovimo, da je še dovolj prostora za nadgradnjo komuniciranja. Predvsem bi lahko bil nov korak zakup svoje domene, kar bi pripomoglo k prepoznavnosti in sledljivosti bloga na iskalnikih in k večjemu številu objav. Prav tako nam analiza komentarjev pove, da blog spremljajo predvsem tisti, ki podpirajo SV in so zainteresirani za njeno delovanje.

\section{Flickr}

To omrežje je SV šele začela razvijati. Uporabljala ga bo za objavo slik večjih resolucij in ustvarjanje obsežnejših foto albumov, ki so primerni tudi za prenos fotografij na osebne računalnike. Med večjimi projekti, ki se jih bodo lotili na tem družbenem

${ }_{12}$ TV-studio MO (https://www.youtube.com/user/MORSstudio/about), ki je na Youtubu aktiven že od 17. decembra 2008, ima 266 naročnikov, več kot 500.000 ogledov ter 266 video vsebin.

${ }^{13}$ Aprila letos so na blogu Slovenske vojske (http://slovenskavojska.blogspot.com/) zaradi velikega zanimanja javnosti o dogajanju v Afganistanu začeli objavljati spletni dnevnik z naslovom Pisma iz peskovnika, v katerem lahko bralec iz prve roke spremlja delovni ritem, utrip vsakdana in zgodbe 19. slovenskega kontingenta $v$

Afganistanu. 
mediju, je tudi projekt z naslovom Naredi si svoj vojaški album. Uporabniki bodo lahko na omrežju poleg sedanjih našli tudi albume, urejene po tematskih sklopih, iz katerih bodo izbirali fotografije, ki jim bodo všeč. O kakšnih večjih komunikacijskih uspehih ali neuspehih na tem omrežju po tako kratkem času še ne moremo govoriti. Zagotovo pa v prihodnje, glede na razvoj zanimanja in glede na bogat izbor fotografij, lahko pričakujemo uspešno slikovno promocijo SV.

\section{NATOV »GOING SOCIAL»}

Nato in njegove članice so že nekaj časa v svojem komuniciranju aktivne tudi na družbenih omrežjih. Zato je po analizi komuniciranja SV na teh omrežjih smiselno pogledati, kako prek teh medijev komunicirajo v teh organizacijah, in potegniti primerjave s SV, saj tako najlažje pridemo do jasne slike, kje je SV v komuniciranju prek družbenih medijev, kam mora iti, kako in kaj mora komunicirati, kako reševati težave, organizirati delo in oblikovati komunikacijsko strategijo.

Iz študije primera nemške vojske Bundeswehr o komuniciranju prek družbenih omrežij (Jacobs, 2012) lahko razberemo, da je strategija odnosov z javnostmi v Nemčiji še vedno pod vplivom zgodovinskih dogodkov in zato manj agresivna od Natovega komuniciranja, a so se kljub temu že pred dvema letoma začeli zavedati pomembnosti aktivnega sodelovanja v novih medijih. V Bundeswehru so se komuniciranja prek družbenih omrežij lotili najprej z delitvijo video vsebin na Youtube, z neposrednim dialogom, na primer na Facebooku, pa so počakali do prvih rezultatov spremljanja aktivnosti na tem kanalu. Dosegli so velik uspeh, v manj kot dveh letih so imeli 22.000 naročnikov in več kot osem milijonov ogledov. Opogumljeni s pozitivno izkušnjo so se slabo leto pozneje lotili komuniciranja prek Facebooka, na katerem imajo danes že več kot 35.000 sledilcev. Prvo komunikacijo na tem omrežju so sprožili v okviru medijske kampanje, ki je potekala pod sloganom »Služimo Nemčiji! ${ }^{14}$ « in je bila posledica ukinitve naborniške vojske. Namen je bil vzbuditi čustva nemškega prebivalstva pri identifikaciji z vojsko, kar jim je tudi uspelo. Tako so prek medijskih kampanj in z načrtnim komuniciranjem nadaljevali postopno vključevanje v družbene medije. Po dveh letih uspešnega komuniciranja znotraj družbenih omrežij se mora oddelek za odnose z javnostmi v nemški vojski ponovno odločiti, kako nadaljevati svojo udeležbo v Spletu 2.0. Do zdaj se je z družbenimi omrežji ukvarjalo nekaj posameznikov (polkovnik, kot vodja oddelka za družbene medije, snemalec, fotograf, urednik družbenih vsebin, administrator, snemalec), ki so komunicirali samo na tem mediju. Če želi nemška vojska ohraniti in še nadgrajevati svoje aktivnosti na družbenih medijih, pa bo treba povečati kadrovske vire in razmisliti o finančnem vložku, ker se sicer lahko zgodi, da po začetnih uspehih na bo novih, vidnejših komunikacijskih dosežkov.

Analiza Natovih aktivnosti (po Masdea, 2012, in Leiderman, 2012) pokaže nekoliko drugačno sliko kot pri komuniciranju Bundeswehra in Slovenske vojske. Predvsem

${ }^{14}$ V izvirniku: »Wir dienen Deutschland.« 
izpostavljam razliko v finančnih in kadrovskih potencialih, razsežnostih komuniciranja in odzivanju na dogodke svetovnega pomena, kar je posledica velikosti in globalnosti zveze. Kljub drugačni sliki analiza Natove politike o socialnih medijih pokaže, da obe v besedilu analizirani vojski delujeta skladno in po usmeritvah zveze, da pa imata obe, predvsem SV, še veliko nerazvitih možnosti in neizkoriščenega potenciala, ki ga ponujajo družbena omrežja.

Nato komunicira prek družbenih medijev po načelu »open door policy « ${ }^{15}$, ki omogoča večsmerno komunikacijo in aktivno udeleževanje javnosti pri komuniciranju z zvezo. Prek svojih družbenih omrežij poroča o vseh pomembnih dogodkih, tudi krizah in revolucijah (kot na primer tvit o koncu revolucije v Libiji, ki ga je po svetu razposlal vrhovni poveljnik zavezniških sil za Evropo), saj sta skladno s strategijo komuniciranja zveze ključnega pomena pravi čas in odzivnost odgovorov, in sicer v smislu, da nobeno vprašanje ne ostane brez odgovora. Nato ima zaradi svoje velikosti več različnih računov, profilov in strani na enakih družbenih omrežjih. Na primer svoj profil na Facebooku (72.660 všečkov) in Twitterju (z 270.120 sledilci) ima Natov HQ, prav tako ju ima generalni sekretar Anderson Fogh Rasmussen (Facebook 84.854 všečkov in Twitter 99.047 sledilcev). V okviru skrbno načrtovane politike komuniciranja ostajata oba kanala strogo usklajena. V okviru svoje strategije komuniciranja zveza opozarja tudi na pasti družbenih omrežij, od razkrivanja informacij do banalizacije vsebin. Zadnja novost, ki jo je uvedla, je najbolj neposredna oblika komunikacije prek družbenih omrežij, tako imenovani »talk-shop«, osebna komunikacija, v kateri lahko z nalaganjem svoje video vsebine prispevaš svoje mnenje o neki temi. S tem Nato spodbuja svoje članice, da pogumno, načrtovano in aktivno stopijo na pot družbene internetne komunikacije.

Po študiji primera komuniciranja SV na družbenih omrežjih in po povzetku študij primerov nemške vojske ter Nata lahko sestavimo primerjalno tabelo. V njej so predstavljene ključne in referenčne točke komuniciranja vseh treh subjektov v Spletu 2.0 (število oboževalcev in komentarjev, časovnica komuniciranja ipd.), ki omogočajo razpravo in sklepe v nadaljevanju besedila.

Iz tabele lahko razberemo, da je Nato številčno neprimerljiv subjekt, saj se po svojem ustroju, delovanju in obsegu bistveno razlikuje od posameznih oboroženih sil. Zato je študija Natovega komuniciranja prek družbenih medijev uporabna predvsem v vsebinskem smislu (kot na primer Natova komunikacijska strategija, načini komuniciranja, organizacija dela znotraj odnosov z javnostmi ipd.). Lahko pa številčno primerjamo Bundeswehr in SV. V absolutnih številkah se zdi nemška vojska neprimerljiva s slovensko, a če pogledamo številke relativno, lahko ugotovimo, da nista tako narazen. Upoštevajoč število prebivalcev v državi kot ključno ciljno javnost komuniciranja obeh vojsk na družbenih omrežjih lahko vidimo, da je na primer sledilcev obeh vojsk na Facebooku 0,3 odstotka prebivalstva (na drugih družbenih omrežjih nemške vojske je odstotek nekoliko višji). Z gotovostjo lahko trdimo, da je SV izdelala dobro strategijo komuniciranja in jo začela intenzivno in uspešno

${ }^{15}$ V prevodu: politika odprtih vrat. 


\begin{tabular}{|c|c|c|c|c|c|}
\hline \multirow{14}{*}{$\begin{array}{r}\text { Primerjalna } \\
\text { tabela statistične } \\
\text { analize dela vseh } \\
\text { treh organizacij } \\
\text { na družbenih } \\
\text { omrežjih }\end{array}$} & & & Nato & Bundeswehr & Slovenska vojska \\
\hline & \multicolumn{2}{|c|}{ Število pripadnikov $\mathrm{OS}^{16}$} & 28 držav članic & $\begin{array}{l}240.572 \text { pripadnikov } \\
\text { profesionalne sestave }\end{array}$ & $\begin{array}{c}7360 \text { pripadnikov } \\
\text { profesionalne sestave }\end{array}$ \\
\hline & \multirow{3}{*}{ Facebook } & všečki strani & 231.362 všečkov & 215.894 všečkov & 4976 \\
\hline & & všečki na album & 1143 & 1264 & 117 \\
\hline & & vsak dan aktivni & 8084 & 8888 & 445 \\
\hline & \multirow{3}{*}{ Youtube } & naročniki & 7411 & 3510 & 58 \\
\hline & & ogledi & 3.507 .657 & 628.983 & 10.817 \\
\hline & & video/teden & 6 & 6,6 & 1,3 \\
\hline & \multirow{2}{*}{ Twitter } & sledilci & 67.461 & 9128 & 272 \\
\hline & & tviti & 1529 & 11.756 & 306 \\
\hline & \multicolumn{2}{|c|}{ Povprečni odzivni čas } & $10-12$ ur & $10-12 u r$ & $12-16$ ur \\
\hline & \multicolumn{2}{|c|}{ Ekipa za družbena omrežja } & večji kolektiv & $7-8$ & $1-2$ \\
\hline & \multicolumn{2}{|c|}{$\begin{array}{l}\text { Začetek udeležbe na } \\
\text { družbenih omrežjih (FB) }\end{array}$} & avgust 2010 & december 2010 & januar 2013 \\
\hline & \multicolumn{2}{|c|}{ Število aktivnih omrežij } & 5 & 5 & 5 \\
\hline
\end{tabular}

Vir: Družbena omrežja proučevanih organizacij in članka o študijah primera.

uresničevati, čeprav je na družbenih omrežjih razmeroma nova, ter da sledi trendom večjih in na družbenih omrežjih dalj časa prisotnih vojsk, a se hkrati zaveda, da bo za nadaljevanje in razvoj teh aktivnosti treba narediti več. Da bo treba povečati število ljudi, ki delujejo na tem področju, načrtovati stroške, izboljšati opremo, izobraževati zaposlene, iskati zamisli pri večjih vojskah, na primer pri nemški. Nekaj teh zamisli in zavedanj bo predstavljenih tudi v razpravi, ki sledi. ${ }^{16}$

\section{»Boj za srca in duše sledilcev $\aleph^{17}$ je SV uspešno začela}

Iz napisanega lahko sklepamo, da družbena omrežja oziroma novi mediji niso več le modna novost, temveč družbena sprememba, ki je postala stvarnost. In ravno to je privedlo $S V$ do vstopa $v$ svet komuniciranja prek teh omrežij. Tudi pripadniki SV se zavedajo, da so družbena omrežja tista, na katerih mora organizacija graditi svojo javno podobo in vzpostaviti neposredno komunikacijo s svojimi javnostmi.

Cilj komuniciranja na družbenih omrežjih je za SV ohranitev prepoznavnosti in pozitivne podobe v najširšem krogu ciljne populacije - splošne slovenske javnosti.

${ }_{16}$ Če želimo imeti številke, uporabne za primerjavo, je določen pokazatelj uspešnosti oziroma razširjenosti komuniciranja o organizaciji odvisen tudi od odstotka prebivalstva v državi-tega dobimo, če poznamo število prebivalstva. V Nemčiji živi 82 milijonov ljudi, v Sloveniji 2 milijona (http://europa.eu/about-eu/countries/ index_sl.htm). Vodstotkih to pomeni, da Bundeswehr na Facebooku spremlja 0,3\% prebivalstva, enako kot SV.

${ }^{17}$ Izraz je uporabljen v članku: Leiderman, 2012, 5,. v izvirniku je zapisan kot »A battle for hearts, minds and followers«. 
In glede na naraščanje števila sledilcev in statistično analizo lahko trdimo, da SV z novim načinom komuniciranja že v začetni fazi dosega zastavljeni namen in ciljne javnosti.

V raziskovalnem delu se je izkazalo, da je SV v komuniciranju prek socialnih omrežij na pravi poti in da z njimi bogato dopolnjuje organizacijsko strategijo in politiko komuniciranja z javnostmi, ki je skladna tudi s politiko zavezništva na tem področju, a za njo še nekoliko zaostaja. V začetni fazi je zato treba slediti zavezniškim oblikam in zamislim komuniciranja prek družbenih omrežij in po opravljeni analizi poskusne dobe ugotoviti, s katerimi postopki SV vzbudi največ zanimanja ciljnih javnosti in najbolj izpolni namen svojega komuniciranja. V prihodnje bi morala biti aktivnost SV na družbenih omrežjih osredotočena na nadgradnjo sedanjih oblik, predvsem v smislu intenzivnejšega udeleževanja v omrežnih povezavah in spodbujanja dvostranske komunikacije. Največ novosti bi lahko uvedli na Twitterju, Youtubu in blogu. $\mathrm{Na}$ Twitterju bi največji napredek dosegli z nakupom mobilnega interneta za vse, ki se ukvarjajo z odnosi z javnostmi, saj bi le tako lahko odzivno »tvitali«, vnaprej bi morali določiti ljudi, ki bi lahko samostojno komunicirali prek tega omrežja, saj to zaradi svoje hitrosti pogosto ne dovoljuje posvetovanj z nadrejenimi. Verjetno bi bilo dobro poskusiti tudi z odprtjem samostojnega kanala za načelnika Generalštaba (kot ga ima generalni sekretar Nata), ker bi s tem dosegli učinkovito razpršenost informacij. Na Youtubu bi morali slediti nemškemu vzoru in prenesti Natovo novost, tako imenovani talk-shope, predvsem pa zagotoviti tehniko za samostojno izdelavo kratkih, ne nujno profesionalnih filmov, ki bi jih objavljali na različnih družbenih omrežjih (nakup vsaj dveh visoko zmogljivih računalnikov s programsko opremo za hitro obdelavo video vsebin, kamera in usposobljen snemalec/montažer) ter zmanjšati čas med dogodkom in objavo video vsebine na minimum. Tudi nadgradnja bloga SV je povezana z denarjem, saj bi bilo treba zakupiti svojo domeno in uvesti še kakšno podstran ali novo rubriko, da bi blog SV postal vidnejši prek iskalnikov (na primer Googla). Razmisliti je treba tudi o uvedbi novih omrežij, kot so na primer Wikipages, Pintrest ali Instagram. Nadgraditi bi morali strategijo komuniciranja in izdelati politiko ter pravila delovanja na družbenih omrežjih. Če SV želi doseči res vidne in stalne rezultate, bo treba dobro usposobiti ključni kader, ki bo sposoben samostojne komunikacije na družbenih omrežjih, s poudarkom tudi na vojaških poveljnikih, ne samo na tistih, ki se ukvarjajo z odnosi z javnostmi. Glede na finančne zmogljivosti pa je treba razmisliti tudi o plačljivih aplikacijah za oglaševanje in prisotnost organizacije na družbenih omrežjih, saj te omogočajo prikazovanje vsebin $v$ času, ko je največ ljudi na internetu, poleg tega pa bi morali še povečati promocijo svojih aktivnosti na družbenih omrežjih na svojih internetnih straneh. In še ena zamisel, kako izboljšati učinkovitost SV na novih medijih - z združevanjem uradnih družbenih omrežij SV in ministrstva v eno omrežje, kot na primer Revije SV in postanivojak.si na Facebooku v enotno stran.

Ob tem, da nekatere organizacije uporabljajo družbena omrežja brez jasnega načrta, le ker je to »moderno« in da dobijo čim več sledilcev, ne smemo pozabiti, da uporaba 
tega medija kot »one size fits all ${ }^{18}$ za varnostne organizacije kot sta Nato in SV ni primerna. Hitenje, da bi čim prej in na vseh omrežjih začeli komunicirati, ne odtehta dobre komunikacijske strategije. Tveganja, kot so širjenje občutljivih nepreverjenih informacij nedoločenega vira, izguba zaupnih podatkov in neodobravanje javnosti, so lahko le posledica nepremišljenega vstopa v komunikacijo prek družbenih omrežij in jih je mogoče preprečiti le z dobro in usklajeno komunikacijsko strategijo.

Po analizi vseh treh študij primerov se je pokazalo, da imajo vse tri vojaške organizacije dobro zastavljeno, deloma tudi uresničeno strategijo komuniciranja na družbenih omrežjih. Medtem ko ima Nato jasno razvito in dodelano politiko, ki jo le še dopolnjuje z novimi zamislimi in novostmi, ter je nemška vojska po dveh letih uspešnega delovanja $v$ točki revitalizacije svoje strategije je SV šele na začetku. Ima dobro zastavljeno strategijo, ki lahko služi kot podlaga za nadaljnji razvoj in izdelavo taktičnega načrta komuniciranja nižjih hierarhičnih ravni, vendar jo bo morala po začetnem obdobju revitalizirati in zapisati v obliki akta. Predvsem bo treba na novo osmisliti točke strategije, ki vključujejo kadrovske in materialne vire. Treba bo predvsem povečati število ljudi, ki se ukvarjajo le z družbenimi mediji in nameniti več finančnih sredstev. Sprememba bo potrebna tudi v analizi povratnih informacij, saj uporaba brezplačnih statističnih programov ne bo več zadostovala za primerno analizo in vrednotenje komuniciranja. Cilji, javnosti, vrsta informacij in načini komuniciranja bodo ostali tudi po začetnem obdobju nespremenjeni, a jih bo treba začeti uresničevati dobesedno na vseh ravneh družbenih omrežij in z veliko večjo intenzivnostjo.

Poleg varnostnega tveganja se pri tej vrsti komuniciranja pojavlja še ena težava. V SV nista dosežena dovolj visoka predanost in zaupanje v družbena omrežja, prav tako organizacijska kultura ni na dovolj visoki ravni, česar ne moremo reči za kulturo obnašanja posameznikov na družbenih omrežjih SV, ki je po analizi odzivov zelo visoka. Tudi odklonilna mnenja in nestrinjanje $\mathrm{z}$ nekaterimi dejavnostmi ali delovanjem SV so namreč izražena sicer kritično, a tudi kulturno, brez žaljenja. Prav tako se vsi v SV še ne zavedajo, da je treba nekaj finančnih sredstev nameniti tudi za zagon in razvoj družbenih medijev organizacije ter da delovanje na tem področju zahteva čas in ljudi, verjetno še več, kot so jih potrebovali klasični mediji, saj je ta tok informacij neprekinjen, traja 24 ur in vseh sedem dni v tednu. Te spremembe naj bi bile prvi korak kot del strategije in naprej kot del usposabljanja ključnih posameznikov za delovanje v novem, večsmernem internetnem okolju.

Ti novi mediji tradicionalno hierarhično vojaško organizacijo ali zvezo iztrgajo iz starih okvirov, približajo jo civilnemu okolju, ki ga intenzivno vključijo v svojo komunikacijo, povečajo preglednost delovanja in se še bolj izpostavijo morebitni kritiki javnosti zaradi tega. Komuniciranje prek novih družbenih medijev je izredno učinkovito in uporabno, a se moramo zavedati, da je to mogočno orožje, ki se lahko obrne tudi proti organizaciji, zato ga je treba uporabljati resno in z organiziranim

18 Izraz je uporabljen v članku: Masdea, 2012, str 1. 
pristopom ter se hkrati zavedati, da samo klasično komuniciranje za kakovostne odnose SV z njenimi javnostmi ni več dovolj.

Literatura

1. Global Online Advertising Spending Statistics. Dostopno na http://www.go-gulf.com/blog/ online-ad-spending/, 6. avgust 2013.

2. A Brief History of Social Advertising - The webby awards. Dostopno na http://tumblr. webbyawards.com/post/57534184521/a-brief-history-of-social-advertising, 6. avgust 2013.

3. Bernet, M., 2010. Social Media in der Medienarbeit, Wiesbaden: VS Verlag für Sozialwissenschaften.

4. Bradley, A., Mcdonald, M., 2011. The Social Organisation. Harward Bussiness Rewiew Press, Gartner Inc, Cambridge.

5. Brankovič, J., 2013. Smo res zaslužili 1,08 milijona? Revija Obramba, letnik 45, julij 2013, str. 10.

6. Jacobs, J., Diefenbach, V., 2012. The Use of Social Media in Public Affairs - A German Perspective. RTO-MP-HFM-201 - Social Media: Risks and Opportunities in Military Applications, April 2012, NATO Science and Technology Organization.

7. Leiderman, L., 2012. Policy making in 140 characters or less: NATO and social media. Nato Research Paper, NDC Rome, No. 77 - April 2012.

8. Masdea, M., 2012. The Challenge of Social Media in Security Policy Institution: A Note of Caution. Nato Research Paper, NDC Rome, No. 78 - June 2012.

9. Mayfield, Antony, 2008. What is social media?. Dostopno na http://www.icrossing.co.uk/ fileadmin/, 3. avgust 2013.

10. NATO, 2011. MC 0457/2 Nato Military Policy on Public Affairs. Dostopno na http://www. nato.int/ims/docu/mil-publ-aff-policy.htm, 20. julij 2012.

11. Socialbakers. Dostopno na http://analytics.socialbakers.com, 1. junij 2013.

12. Suhadolc, J., 2007. Nove priložnosti E-komuniciranja. Ljubljana: GV Založba.

13. Vehovar, V., in dr., 2012. Socialna omrežja 2011. Raba interneta v Sloveniji. Dostopno na http://www.ris.org/db/13/12076/RIS\%20poročila/Socialna_omrezja_2011, 5. avgust 2013.

14. Žbogar, D., 2010. Vpliv družbenih medijev na prakso odnosov z javnostmi. Published thesis, Ljubljana: Fakulteta za družbene vede. 


\section{EVALVACIJA ODNOSOV Z JAVNOSTMI V SLOVENSKI VOJSKI}

\section{EVALUATION OF SLOVENIAN ARMED FORCES PUBLIC AFFAIRS}

Povzetek Kakovostni odnosi z javnostmi so pomembni za delovanje in legitimnost oboroženih sil. Podatek o zaupanju javnosti v oborožene sile je pomembna povratna informacija vsem zaposlenim v njih in motivacija za nadaljnje delo.

V prispevku je predstavljena evalvacija odnosov z javnostmi v Slovenski vojski. Opravljena je bila znotraj štirih različnih projektov in je trajala od aprila 2010 do julija 2013. Namen evalvacije je bil ugotoviti, kako kakovostno je področje dela odnosov z javnostmi v Slovenski vojski. V evalvacijo so bile vključene različne javnosti, notranjo so predstavljali vzorci vojakov, podčastnikov in častnikov, zunanjo pa predstavniki slovenskih medijev ter strokovnjaki in akademiki, specializirani za področje odnosov z javnostmi.

Ključne Odnosi z javnostmi, evalvacija, oborožene sile, Slovenska vojska, javno mnenje, besede javno zaupanje.

Abstract Quality public affairs are important for the functioning and legitimacy of the armed forces. Data on public trust in the armed forces are an important feedback to all employees and their motivation for further work.

The paper presents an evaluation of public affairs in the Slovenian Armed Forces. It has been carried out within four different projects from April 2010 to July 2013. The aim of the evaluation was to determine the quality of public affairs in the Slovenian Armed Forces. The evaluation included different publics; the internal public represented by soldiers, NCOs and officers, and the external public represented by Slovenian and foreign media representatives, as well as experts and scholars specializing in the field of public relations.

Key words Public affairs, evaluation, armed forces, Slovenian Armed Forces, public opinion, public trust. 
Uvod Slovenska vojska (SV) po raziskavah Centra za raziskovanje javnega mnenja (CJM) dosega od osamosvojitve Slovenije razmeroma visoke uvrstitve na lestvici zaupanja slovenske javnosti v javne institucije. Zaupanje javnosti v vojsko kot državno institucijo je velikega pomena in neposredno povezano z razmerami za njeno delovanje. Splošna javnost in javni politični odločevalci sta tisti ciljni javnosti, ki lahko vplivata, politični odločevalci pa tudi odločajo o poslanstvu, delovanju, financiranju in prihodnosti oboroženih sil. Vse to vpliva na kakovost delovanja, ki pa je v primerjavi z zunanjimi javnostmi odvisno tudi od notranje ali interne javnosti v oboroženih silah. Notranjo ali notranje javnosti v obrambnem sistemu predstavljajo vsi zaposleni, z različnimi statusi, kot na primer civilne (uradniki, strokovno-tehnični delavci) in vojaške osebe (vojaki, podčastniki, častniki in generali ter vojaški uslužbenci) v različnih notranjih organizacijskih enotah, poudarek v tem članku pa bo na zaposlenih v vojski.

Zaupanje javnosti v državne institucije je pomembno z vidika delovanja države. Ta v demokratičnih družbah želi delovati javno, pregledno in v sodelovanju s civilno družbo, in sicer z namenom doseči najboljše učinke pri opravljanju svojega poslanstva. Oborožene sile spadajo med represivne državne organe, ki svoje poslanstvo opravljajo zelo drugače kot druge državne institucije. Ta posebnost se kaže tudi v uporabi orožja in delovanju zunaj državnih meja v mednarodnih operacijah in na misijah v varnostno tveganih okoljih in razmerah. To pomeni večjo odgovornost za politične odločevalce, ki o takih napotitvah odločajo, hkrati pa tudi za zaposlene v oboroženih silah, ki morajo biti dodatno usposobljeni in opremljeni zaradi morebitne večje nevarnosti pri opravljanju njihovega poslanstva. Pri vsem tem imajo pomembno vlogo odnosi z javnostmi, ki veliko prispevajo k obveščenosti javnosti o delovanju oboroženih sil in hkrati k zaupanju vanje.

Kako kakovostno je področje dela odnosov z javnostmi v SV?

Iz zaupanja slovenske javnosti v javne institucije lahko na primeru SV sklepamo, da tako vojska kot zaposleni v njej dobro opravljajo svoje poslanstvo. Po podatkih CJM celo zelo dobro, saj je stopnja zaupanja v SV sorazmerno stalna glede na to, da se zaupanje v druge javne institucije v primerjavi s SV zmanjšuje. Za javno podobo SV strokovno skrbijo zaposleni na področju odnosov z javnostmi ${ }^{1}$. Meritve slovenskega javnega mnenja so samo eden izmed pokazateljev zunanje kakovosti delovanja odnosov z javnostmi v vojski, zato smo želeli preveriti tudi druge načine ocenjevanja kakovosti tega področja, na primer notranjo javnost in predstavnike medijev, pri čemer smo uporabili metodo evalvacije.

Na javno podobo SV in s tem na zaupanje javnosti vpliva vsak posameznik s svojo fizično pojavo in svojim delovanjem tako v službi kot v prostem času. 


\section{TEORETIČNA IZHODIŠČA, POMEMBNA ZA EVALVACIJO}

\subsection{Odnosi z javnostmi}

Pojem odnosi z javnostmi (Public Relations) je rezultat dela Edwarda L. Bernaysa ${ }^{2}$, ki se je oprl na dve deli iz 19. stoletja, avtorjev Dormana B. Eatona ${ }^{3}$ (1882) in Hougha Smitha ${ }^{4}$ (1842), ki sta takrat pisala o javnih odnosih, pozneje pa se je pojem postopoma preoblikoval $\mathrm{v}$ odnose $\mathrm{z}$ javnostmi. Bernays sam je zapisal, da odnosi z javnostmi pomenijo natančno to, kar piše, odnose organizacije, posameznika, ideje ali česar koli že z javnostmi, od katerih je odvisen njihov obstoj (Bernays, 1986, str. 35, v Verčič, 1995, str. 17).

Hallahan razume odnose z javnostmi kot eno izmed šestih disciplin, ki sestavljajo koncept komunikacijskega menedžmenta, hkrati pa poudarja, da imajo posamezne komunikacijske discipline skupen namen, njihovi cilji in strategije pa so si zelo podobni. Razlikujejo se predvsem v taktiki, željah organizacij po usklajevanju komuniciranja, konvergenci medijev in zabrisovanju meja med komunikacijskimi zvrstmi, ki jih silijo k prilagajanju spreminjajočemu se okolju. Nadaljuje, da organizacije stremijo $\mathrm{k}$ integraciji in večji uspešnosti predvsem s sinergijo in boljšo učinkovitostjo ter manj s tehnološkimi presežki (Hallahan in dr., 2008, str. 630). Poleg odnosov z javnostmi so druge discipline še upravljavsko (menedžersko), tržno, strokovno in politično komuniciranje ter informativne oziroma družbene kampanje (prav tam).

Mednarodno združenje za odnose z javnostjo je opredelilo te odnose kot $\gg / . . . /$ veščino in družbeno vedo o analiziranju trendov, napovedovanju njihovih posledic, svetovanju organizacijskim vodjem in izvajanju načrtovanih programov dejanj $\mathrm{v}$ interesu skupnosti in javnosti.« (Verčič, 1999, str. 520-521)

Tiskovni predstavnik SV Simon Korez pravi: »Če želimo uresničevati poslanstvo stroke, kot ga opredeljuje ena od številnih definicij, je treba odnose z javnostjo voditi na strateški način, s pomočjo pretehtanega načrtovanja, pozornega vodenja dejavnosti ter stalnega raziskovanja in vrednotenja učinkov komuniciranja. Odločanje za posamične in ad hoc dejavnosti ne more zagotoviti uspešnega in učinkovitega komuniciranja.« (Korez, 2008, str. 58)

Kot nadaljuje Korez, je razumevanje odnosov z javnostmi povezano predvsem z doseganjem publicitete $\mathrm{v}$ medijih in to za vsako ceno. Odnosi z mediji kot posredovalci in tudi oblikovalci sporočanja so pomembno področje delovanja, nikakor pa ne edino.

\footnotetext{
Edward Luis Bernays (1891-1995), rojen v Avstriji, živel v ZDA. Velja za »očeta odnosov z javnostmi«.Združil je ugotovitve na področju psihologije množic in psihoanalizo svojega strica Sigmunda Freuda. Po oceni revije Life magazine velja za eno od stotih najvplivnejših oseb 20. stoletja.

3 Avtor knjige The public Realtions and Duties othe Legal Proffession.

4 Avtor knjige The Theory and Regulation of Pubic Setiment.
} 
Tako komunikacijske dejavnosti niso same sebi namen. Komunikatorji jih vodijo predvsem v podporo doseganju organizacijskih poslovnih ciljev. »V vojaški skupnosti so to naslednji cilji: pozitivna javna podoba Slovenske vojske, pozitivna, vendar realna promocija vojaškega poklica (v vojaški skupnosti ne sme biti propagande), podpora poveljnikom pri sprejemanju odločitev za ukrepe pri vodenju in poveljevanju ter priprava in vodenje komunikacijskih strategij za podporo projektom.« (prav tam)

\subsection{Evalvacija na področju odnosov $\mathrm{z}$ javnostmi}

Beseda evalvacija v slovenskem jeziku pomeni ocenjevanje, vrednotenje, slovar angleškega jezika pa jo pojasnjuje tudi kot preračunavanje, določitev vrednosti. V literaturi se pojavlja tudi zapis evaluacija, vendar je zelo redek.

Paton pravi, da je vrednotenje sistemsko zbiranje, analiziranje in ocenjevanje informacij o aktivnostih, značilnostih in rezultatih programov, da bi tako zmanjšali negotovost, povečali uspešnost ter oblikovali odločitve skladno s cilji in nameni programov (1986).

Razlika med vrednotenjem in raziskovanjem je po Bennetovi (2003, str. 14) v tem, da je raziskovanje usmerjeno $\mathrm{v}$ razumevanje pojava, ki ga raziskuje, vrednotenje pa $\mathrm{v}$ odkrivanje vrednosti in koristi nekega projekta. Bennetova razume raziskovanje kot ožje usmerjeno, pri čemer je pomembna strokovna veljavnost, vrednotenje pa kot bolj celovito, pri čemer sta pomembni uporabnost in verodostojnost. Kot pravi Serajnikova, rezultati vrednotenja na področju odnosov z javnostmi prispevajo $\mathrm{k}$ spremembam - na bolje ali na slabše (opustitev programa oziroma dela), odprejo se kritična vprašanja in poveča se občutljivost vpletenih (2008, str. 850).

V povezavi z evalvacijo na področju odnosov z javnostmi loči Rühl tri pristope: laičnega, strokovnega (profesionalnega) in akademskega. Pri laičnem se praktiki zanašajo na zdravo presojo. Delujejo, presojajo in ocenjujejo na podlagi svojih izkušenj in občutkov. Strokovnjaki prisegajo na profesionalne formalne (zakoni, kodeksi, standardi itn.) ter neformalne norme (morala, zaupanje, odgovornost itn.), ki jih postavljajo in negujejo organizacije. Merjenja in vrednotenja se organizirano lotevajo nacionalna in mednarodna združenja. Akademska skupnost loči med aplikativnim in znanstvenim raziskovanjem. Prvo si prizadeva najti praktične rešitve za strateško načrtovanje in delovanje, usmerjeno pa je na področje poklicne prakse odnosov z javnostmi, v oblikovanje oblik ter načinov konceptualizacije in uveljavitve komunikacijskega menedžmenta za doseganje uspešnosti in učinkovitosti. Znanstvenega raziskovanja je bistveno manj (Rühl, 2008, str. 21).

Ključno vprašanje pri tem pa je, kaj odnosi z javnostmi prispevajo družbeno, organizacijsko, funkcionalno, programsko, projektno in individualno. Da bi vse našteto ugotovili, je nujno raziskovanje odnosov z javnostmi. Rühlov članek ${ }^{5}$ tremi pristopi

Članek Public relations methodology Should we bother (If it exists)? v monografiji avtorjev Betteke, Tkalac

Verčič in Verčič z naslovom Public relations metrics: Research and evaluations. 
k evalvaciji odnosov z javnostmi nam je bil vodilo pri evalvaciji v SV. V njem pravi, da je sociološki pogled na upravljanje odnosov z javnostmi kot funkcionalnega sistema predvsem v spodbujanju in ohranjanju javnega interesa in javnega zaupanja. Zunanji vidik odnose $\mathrm{z}$ javnostmi pokaže kot sistem vsakodnevnega prepričevanja javnosti, medtem ko notranji vidik lahko razumemo dvojno, kot prakso stroke in kot podpodročje komuniciranja s svojim raziskovanjem in teoretičnimi podlagami (Rühl, 2008, str. 21). Odnosov z javnostmi tako ne moremo vrednotiti v finančnem smislu, saj so njihovi ključni rezultati pozornost javnosti, strokovno delo, moralna načela, smiselnost informacij, spodbujanje novih tem, uravnoteženost zakonodaje ter zaupanje javnosti in posameznikov (prav tam).

\subsubsection{Javno mnenje kot eden izmed kazalnikov kakovosti odnosov z javnostmi v oboroženih silah}

Javno mnenje je najsplošnejši izraz mnenj, stališč in razpoloženj javnosti o vprašanjih splošnega interesa, pravita Rus in Toš. Javno mnenje je le končni izraz, večinska ali kolektivna sodba, ki jo v mnenjskem procesu poda javnost in je družbeno determinirana. Kot pravita avtorja, gre za posledico dinamičnega in protislovnega mnenjskega procesa v temeljni skupnostni ravnini, ki pa se v nadaljnjem mnenjskem procesu modificira ali celo spremeni (2005, str. 336-369).

Spremembe, ki so vplivale na mednarodno varnostno okolje po koncu hladne vojne in 11. septembru 2001, se kažejo tudi na oboroženih silah in njihovih odnosih z javnostmi. Postmoderno sodobno vojsko zaznamuje vse večja odprtost vojaških organizacij v komuniciranju z javnostmi, v izmenjavi informacij in dostopnosti do njih, v večji lastni medijski produkciji ter pripravljenosti za sodelovanje z množičnimi mediji (prav tam).

Na preobrazbo v komuniciranju vojaške sfere so pomembno vplivali zlasti:

- opuščanje obvezniškega popolnjevanja in prehod na (popolnoma) poklicno vojsko;

- vpliv globalizacije in sodobnih komunikacijskih tehnologij;

- proces demokratizacije in spreminjanja vrednot, naraščajoči pomen človekovih pravic te preprečevanje kritičnih zahtev javnosti (Van Dyke, Verčič, 2009).

Teoretični okvir za raziskovanje vloge oboroženih sil v odnosu do javnosti je $\mathrm{v}$ prejšnjem stoletju postavil Huntington, pozneje pa so ga pomembno nadgradili Edmonds, Jelušičeva in drugi. Bistvo njegove teze je, da se vojske kot družbene institucije lahko ohranjajo le, »/.../ če izpolnjujejo imperative javnosti« (Huntington, 1957). Oborožene sile in obrambni sistemi $» / \ldots /$ se morajo prilagajati zahtevam javnosti, vendar pa te zahteve predhodno sooblikujejo s poseganjem v proces oblikovanja javnega mnenja /.../« meni Prezelj (1997, str. 1020). Z vidika javnosti in medijev se zastavlja vprašanje ravnotežja med izpolnjevanjem socialnega in funkcionalnega imperativa. Slednji predstavlja temeljno poslanstvo vojske - torej obrambo države v razmerju do socialnega imperativa, ki je »/.../ rezultat ideologij, vrednot in kulturnih norm« (Jelušič, 1997, str. 68). 
Prezelj pa pravi, da »/.../ bolj kot se zdi, da vojska deluje v duhu postavljenih zahtev, bolj je sprejemljiva za javnost v celoti in tudi za posebne javnosti. Sprejemljivost določene državne institucije pa je pogoj za doseganje lojalnosti državljanov in za priznanje legitimnosti /.../« (Prezelj, 1997, str. 21). Kot pravi Jelušičeva, je legitimnost varnostne politike in oboroženih sil v demokratično oblikovani družbi izpostavljena neprestanemu preverjanju in vplivanju. Legitimnost ni nekaj trdno zagotovljenega, kar bi bilo enkrat doseženo in bi obstajalo za vse večne čase, temveč se vedno znova sooča s svojimi temeljnimi problemi. Vedno znova je izpostavljena javni pozornosti, kritiki in nadzoru (1997, str. 171).

Korez potrjuje teze naštetih avtorjev in hkrati izraža zavedanje zaposlenih, ki se v oboroženih silah ukvarjajo z odnosi z javnostmi, ko omenja, da izvajalci komunikacijskih strategij upoštevajo javno mnenje pri načrtovanju svojega dela in poskušajo nanj z različnimi oblikami proaktivnega dela tudi vplivati. Posebej poudari, da javno mnenje izraža predvsem aktivna javnost, ki ima nespremenljiva in aktivna stališča. Pomemben del za področje dela odnosov z javnostmi pa je tudi neaktivna javnost, ki postane aktivna ob kakšnem širšem splošnem vprašanju. Tako oborožene sile brez podpore javnosti ne morejo učinkovito izvajati nobenih novih nalog, pri čemer posebej izpostavlja pomen javnega mnenja v povezavi s sodelovanjem oboroženih sil v mednarodnih operacijah in na misijah (Korez, 2008, str. 61).

\section{METODOLOŠKI PRISTOP K EVALVACIJI ODNOSOV Z JAVNOSTMI V SLOVENSKI VOJSKI}

Ministrstvo za obrambo ima več organizacijskih enot, na primer SV, upravni del, Upravo RS za zaščito in reševanje (URSZR) in druge. Za področje odnosov z javnostmi je organizirana Služba za strateško komuniciranje. SV in URSZR imata svoja predstavnika za odnose z javnostmi, pri čemer ima SV v ta namen tudi poseben sektor.

Da bi ugotovili, kako kakovostno je področje dela odnosov z javnostmi v SV, je bilo v Sektorju za odnose z javnostmi na Generalštabu SV izvedenih več različnih projektov, pri katerih smo se osredotočili na notranjo in zunanjo javnost.

Notranjo javnost razumemo kot vse zaposlene v obrambnem sistemu, ki prek različnih medijev spremljajo dogajanje v njem in zunaj njega. Ministrstvo ima na voljo poseben notranji spletni portal, imenovan Infotočka, prek katerega vsak dan obvešča zaposlene o najrazličnejših aktualnih vsebinah in dogodkih, ki v njem nastajajo. Vsebuje pa tudi različne stalne rubrike o pravnih aktih, sindikatih, športu, izobraževanju in usposabljanju ter drugih področjih. Za komuniciranje z zaposlenimi ima SV tudi več publikacij, ki so namenjene seznanjanju bralcev z različnimi dejavnostmi posameznih enot (revija Prvi, Prava smer, Modri), z vojaškim učnim procesom (Vojaškošolski zbornik) ali posameznim področjem (Vojaška zgodovina). 
Zunanjo javnost razumemo kot vse tiste posameznike, združenja ali skupine, ki niso zaposleni $\mathrm{v}$ obrambnem sistemu. SV z zunanjo javnostjo komunicira prek različnih objav na spletnih staneh ministrstva in SV, z izjavami tiskovnega predstavnika in drugih zaposlenih, $\mathrm{z}$ različnimi publikacijami ter organiziranjem tiskovnih konferenc in drugih dogodkov za medije in posamezne ciljne skupine.

Gre za ciljno skupino, ki je veliko težje določljiva in dosegljiva za vrednotenje v smislu evalvacije. Kdo so torej tisti deli zunanje javnosti, ki lahko najbolje ocenijo delo na področju odnosov z javnostmi? Po naših ugotovitvah so to predstavniki medijev, ki s SV bolj ali manj redno sodelujejo. Da bi dobili širše vedenje, smo se odločili več pozornosti nameniti tudi rezultatom CJM, in sicer pri merjenju zaupanja slovenske javnosti v institucije, s poudarkom na SV, in interpretaciji teh rezultatov.

\begin{tabular}{|c|c|c|c|}
\hline \multirow{4}{*}{$\begin{array}{r}\text { Preglednica 1: } \\
\text { Pristopi k } \\
\text { evalvaciji po } \\
\text { Rühlu v povezavi } \\
\text { s posameznimi } \\
\text { projekti SV } \\
\text { na področju } \\
\text { odnosov z } \\
\text { javnostmi }\end{array}$} & $\begin{array}{l}\text { Pristopi k evalvaciji } \\
\text { po Rühlu }\end{array}$ & Notranja javnost & Zunanja javnost \\
\hline & laični pristop & $\begin{array}{c}\text { prvi projekt: Notranji spletni portal } \\
\text { INFOTOČKA }\end{array}$ & $\begin{array}{c}\text { četrti projekt: Zaupanje javnosti } \\
\text { v SV }\end{array}$ \\
\hline & strokovni & $\begin{aligned} & \text { drugi projekt: } \text { Komuniciranje z } \\
& \text { notranjo javnostjo SV }\end{aligned}$ & $\begin{aligned} \text { tretji projekt: } & \text { Komuniciranje SV s } \\
& \text { predstavniki medijev } \\
\text { četrti projekt: } & \text { Zaupanje javnosti } \\
& \text { V SV }\end{aligned}$ \\
\hline & akademski & & $\begin{array}{c}\text { četrti projekt: Zaupanje javnosti } \\
\text { v SV }\end{array}$ \\
\hline
\end{tabular}

\subsection{Prvi projekt: Notranji spletni portal INFOTOČKA}

Notranja spletna stran ministrstva je bila leta 2009 prenovljena. Dodatno je bila uvedena Infotočka, komunikacijsko orodje oziroma portal za notranje informiranje pripadnikov SV.

Za evalvacijo Infotočke je bil po njeni uvedbi zaposlenim razdeljen poseben vprašalnik, zasnovan tako, da bi ugotovili njeno uporabnost, aktualnost in funkcionalnost, uredili celostno podobo in dodali nove informacije, rubrike ali komunikacijska orodja, ki bi čim bolj izpolnjevala pričakovanja zaposlenih v SV.

Vprašalnik je bil razdeljen 530 pripadnikom SV, in sicer vojakom, podčastnikom in nižjim vojaškim uslužbencem ${ }^{6}$ (kar je 10-odstotni delež v vzorcu vseh). Vprašalnike so izpolnjevali v času od 15. marca do 15. aprila 2010.

${ }^{6}$ Leta 2010 je bilo njihovo število približno 5300. 


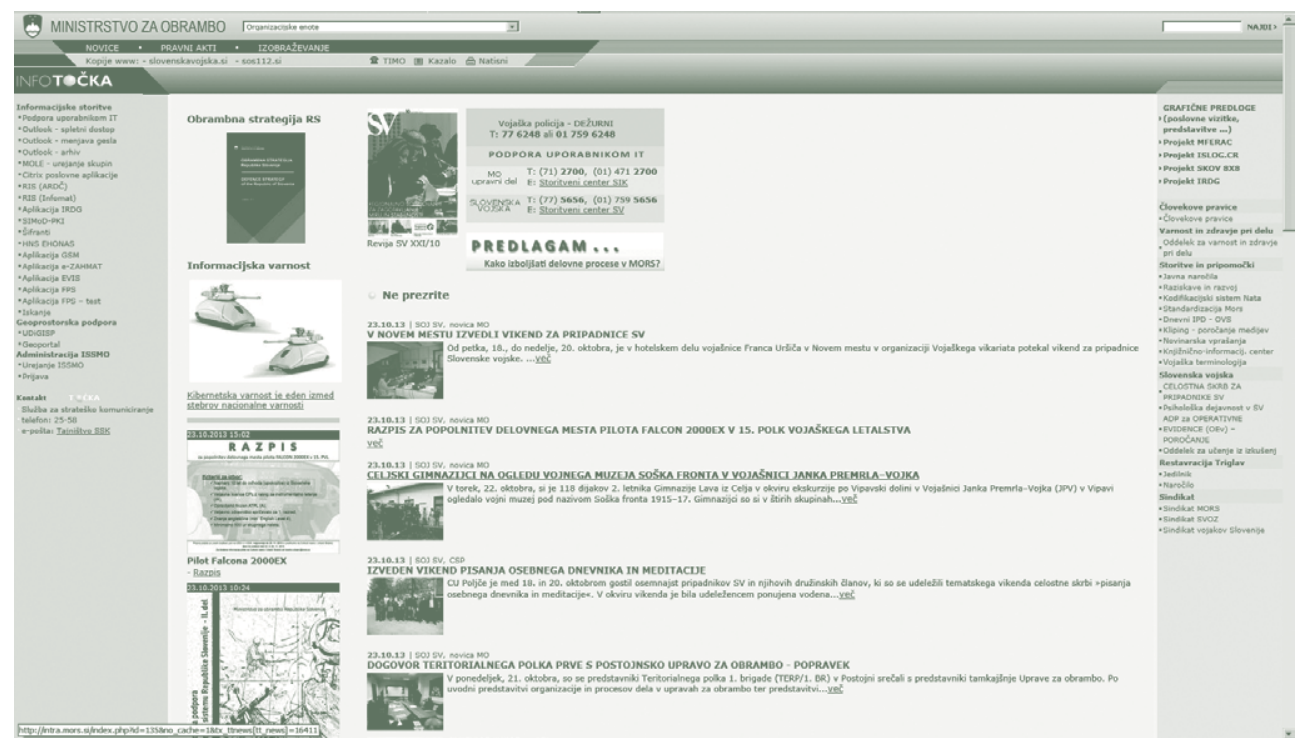

\subsection{Drugi projekt: Komuniciranje z notranjo javnostjo SV}

Evalvacija notranjega komuniciranja v SV je bila opravljena v sodelovanju z agencijo Pristop. Namen vprašalnika je bil:

- pridobiti informacije o medijskih navadah zaposlenih častnikov v SV;

- pridobiti oceno trenutnega stanja notranjega komuniciranja v SV;

- opredeliti potrebe, želje in pričakovanja zaposlenih častnikov, povezana z notranjim komuniciranjem v SV;

- odkriti največje vrzeli v notranjem komuniciranju v SV, ki bodo podlaga za njegovo nadaljnje upravljanje.

Vprašalnik je vseboval tri vsebinske sklope: oceno notranjega komuniciranja v SV (kako pogosto iščejo informacije o SV in kje jih dobijo, kako jih ocenjujejo, kaj predlagajo za izboljšanje), medijsko potrošnjo (katere zunanje in notranje medije spremljajo, kako pogosto, kje dobijo največ informacij) ter demografske podatke o sodelujočih.

Vprašalnik je bil objavljen na spletnih straneh http://surveymonkey.com/s/mors-vprasalnik. Častniki so ga izpolnjevali v času od 25. oktobra do 10. novembra 2010. Dobili smo 210 izpolnjenih vprašalnikov (kar je približno 17-odstotni delež vseh častnikov, zaposlenih $\mathrm{SV}^{7}$ ). 


\subsection{Tretji projekt: Komuniciranje SV s predstavniki medijev}

Vprašalnik za predstavnike medijev je bil pripravljen z namenom, da se ovrednoti in izboljša področje dela odnosov z javnostmi. Sestavljen je bil iz treh sklopov, in sicer mediji in SV, sodelovanje predstavnikov medijev s predstavniki za odnose $\mathrm{z}$ javnostmi v SV ter obiski predstavnikov medijev, ki jih v mednarodnih operacijah in na misijah organizira SV. Vprašalniki so bili poslani predstavnikom medijev in njihovim uredništvom konec decembra 2011 in v začetku januarja 2012. V evalvaciji so bili upoštevani vsi vprašalniki, ki so bili izpolnjeni do konca februarja 2012.

\section{4 Četrti projekt: Zaupanje javnosti v SV}

V sodelovanju z revijo Obramba je bil izveden projekt, katerega cilj je bil povabiti k sodelovanju različne strokovnjake na področju odnosov z javnostmi in pridobiti njihova mnenja o zaupanju slovenske javnosti v SV v povezavi z rezultati CJM, ki večkrat na leto meri zaupanje javnosti v javne institucije.

Na povabilo so se odzvali: nekdanji zaposleni v agenciji Pristop, ki je sodeloval v medijskih akcijah skupaj s $\mathrm{SV}^{8}$, dve doktorici znanosti s Katedre za obramboslovje Fakultete za družbene vede in trije novinarji, ki redno in profesionalno spremljajo aktivnosti SV. Mnenja vseh so bila objavljena v reviji Obramba julija 2013, skupaj z intervjujem s tiskovnim predstavnikom SV.

V konceptu pristopa k evalvaciji je bil upoštevan tako imenovani celostni pristop, $\mathrm{s}$ katerim smo želeli zajeti vse tiste javnosti, ki kakor koli lahko prispevajo k vrednotenju odnosov z javnostmi v SV. V prvem primeru so bili ciljna javnost vojaki, podčastniki in nižji vojaški uslužbenci, v drugem so se na vprašalnik odzvali častniki in višji vojaški uslužbenci, v tretjem so sodelovali predstavniki večjih medijskih hiš in lokalni novinarji, v četrtem pa splošna laična javnost, zajeta v vzorec vprašanih v anketi $\mathrm{CJM}^{9}$, in tisti, ki se z odnosi zjavnostmi ukvarjajo profesionalno ali akademsko. Tako smo si prizadevali čim bolj upoštevati različna teoretična izhodišča domačih (Verčič, Serajnik Sraka itn.) in tujih avtorjev (Bernays, Huntington itn.), da bi evalvacija tako prispevala $\mathrm{h}$ kakovostnemu vrednotenju in stvarni oceni stanja, hkrati pa podala usmeritve za prihodnje delo. V metodološkem smislu pa smo izhajali iz pristopov k evalvaciji po Rühlu (2008).

\footnotetext{
Leta 2010 je SV skupaj s Pristopom prejela eno izmed nagrad Effie za tržno učinkovitost. Ponosni nase je bila predstavitev, ki je imela temeljni cilj seznaniti mlade z možnostjo poklicnega vključevanja $v$ SV. Zasnovana je bila $v$ času velike gospodarske rasti, ko je trg delovne sile intenzivno zaposloval kader, zaposljiv tudi v SV. $S V$ je skupaj z Ministrstvom za obrambo izbrala agencijo in pripravila celovit projekt, ki je bil usmerjen $v$ nagovarjanje mladih za zaposlitev v SV. Zaradi te celovitosti je bila to posebna promocijska akcija, ki je imela tržno učinkovitost (intervju s Korezom v reviji Obramba, julij 2013).

9 Vzorci v povprečju vsebujejo med 800 in 1000 sodelujočih pri vsaki meritvi posebej. Več na http://www.cjm. si/?q=PB_rezultati, 18. 10. 2013.
} 


\section{RAZISKAVA}

\subsection{Infotočka - rezultati}

Prejeli smo 605 izpolnjenih vprašalnikov. Od tega so jih 70 odstotkov izpolnili vojaki, 16 odstotkov podčastniki, 9,5 odstotka častniki in štiri odstotke vojaški uslužbenci. $Z$ vidika celostne podobe je bila Infotočka ocenjena s povprečno oceno 2,93, organiziranost rubrik s povprečno oceno 2,79 , preglednost z 2,81, funkcionalnost vsebin s povprečno oceno 2,78 , aktualnost z 2,8 , način posredovanja informacij z 2,83 in uporabnost z 2,69.

V rubriki »vaše mnenje«, v kateri je bil predviden prostor za predloge vprašanih, se je pojavilo veliko različnih predlogov, ki pa so bili zelo specifični in povezani s posameznimi področji ali enotami.

$\mathrm{Na}$ vprašanje, o katerih področjih bi si zaposleni želeli pridobiti več informacij, smo dobili odgovore, ki so razvrščeni glede na izkazani interes vprašanih (možnih več odgovorov). Največ zanimanja je bilo za informacije, povezane z možnostmi napredovanja (363), na drugem mestu so bile informacije o plačah (334), na tretjem pravne razlage zakonodaje (314), na četrtem možnosti dela v mednarodnih operacijah in na misijah (299) ter o vojaškem izobraževanju in usposabljanju (299), na šestem mestu o jezikovnih tečajih po sistemu e-izobraževanja (274), na sedmem o vojaškem izobraževanju in usposabljanju v tujini (266) ter o dopustih (266), na osmem o možnostih dela v tujini (258) in na zadnjem, devetem mestu, o izobraževanju na splošno (44).

V rubriki »vaše mnenje in predlogi« so vprašani našteli: več informacij o športnih dogodkih, ki jih organizira SV ali v njih sodeluje, o spremembah organiziranosti delovanja SV in MO, o možnostih različnih letovanj, streliščih, uradnih stališčih SV do komentarjev, povezanih s SV v medijih, o usposabljanjih na področju informacijske tehnologije, o razpisih za prosta delovna mesta v SV in na MO, na misijah in $\mathrm{v}$ tujini ter drugo.

\subsection{Kakovost notranjega komuniciranja v SV z vidika zaposlenih}

Rezultati anketiranja, ki je bilo organizirano v sodelovanju z agencijo Pristop, so bili na rednem mesečnem usposabljanju aprila 2011 na Vrhniki predstavljeni zaposlenim, ki delajo na področju odnosov z javnostmi v SV. Sestavljeni so bili iz dveh sklopov: kakovosti notranjega komuniciranja v SV in analize glasil.

Največ informacij dobijo zaposleni od neposredno nadrejenih. Na Likartovi lestvici od 1 do 5 so vprašani izbrali zanje povprečno oceno 3,36. Sledijo informacije z Infotočke s 3,35, na tretjem mestu so sodelavci z oceno 3,33 in na četrtem elektronska pošta $z$ oceno 3,27 . Na petem mestu je bila revija SV z oceno 2,67, na šestem drugi nadrejeni z oceno 2,59 in na sedmem revija Obramba z oceno 2,55. 
Publikacije SV so si kot vir informacij sledile po tem vrstnem redu: Bilten Slovenske vojske z oceno 1,79, Prvi z oceno 1,44, Prava smer z 1,24, Častno in predano z oceno 1,20 in Ujma z 1,19.

Kot vir informacij so se neposredno nadrejeni v deležu odgovorov z možno izbiro pogosto in zelo pogosto pojavili v 52,2 odstotka, drugi sodelavci v 48 odstotkih, Infotočka v 53,2 odstotka in elektronska sporočila v 53,9 odstotka.

Med informacijami, o katerih bi zaposleni želeli vedeti več, se je na prvem mestu znašla tema o delovanju drugih vojsk, in sicer je 75 odstotkov vprašanih menilo, da je o tej temi premalo informacij. O napredovanju v obrambnem sistemu bi želelo vedeti več 73,8 odstotka vprašanih, o drugih organizacijskih enotah pa 71 odstotkov, o zaposlovanju novih vojakov 69,3 odstotka, o strategiji, viziji in ciljih obrambnega sistema 67,2 odstotka vprašanih, o družbeno odgovornem delovanju sistema 66,5 odstotka, o delovanju Nata 66,6 odstotka itn.

Zaposleni si v rubriki o temah, o katerih bi želeli biti obveščeni po svoji izbiri, najbolj želijo korektne obveščenosti o delovanju znotraj sistema, in sicer je takih 34,5 odstotka, na drugem mestu so kadrovske zadeve z 22,7 odstotka, ki jim sledijo teme o razvoju SV z 21,8 odstotka.

Publikacije so vprašani ocenili kot pretežno informativne, bogate s slikovnim gradivom. Kot prednosti so prepoznali redno izhajanje, pestro izbiro avtorjev in intervjuje. Hkrati pa so po mnenju vprašanih glasila precej statična. Narava obveščanja je zelo formalna, nedinamična oziroma toga. Prevladujejo vsebine o organizaciji, premalo je vsebin o ljudeh, stroki, rubrike so premalo pestre. Kot govorci se pojavljajo predvsem zaposleni z višjimi čini in na višjih položajih. Jezik je »pust«, naslovi »nedinamični in zgolj informativni«. Kot dober primer glasila je bila izpostavljena revija Prvi.

Ključne ugotovitve iz vprašalnika so:

- orodja notranjega komuniciranja so omejeno učinkovita. Na voljo jih je dovolj, vendar niso v celoti izkoriščena;

- v sistemu sta dve skupini zaposlenih. Prva je skupina vojakov s časovno omejeno pogodbo o zaposlitvi. Zanimajo jih informacije o delovnem razmerju, so mlajši od 36 let, imajo manj kot 11 let delovne dobe in so najmanj zadovoljni z notranjim komuniciranjem. Zanimajo jih komunikacijska orodja mlajših generacij in večino informacij iščejo zunaj sistema. Drugo skupino predstavljajo zaposleni za nedoločen čas, v povprečju imajo višjo izobrazbo, višje čine in več delovne dobe. Njihova pričakovanja, povezana z internim komuniciranjem, so veliko večja, bolje poznajo organizacijo in poslanstvo sistema, uporabljajo vsa komunikacijska orodja in so z njimi veliko bolj zadovoljni kot prva skupina;

- medosebno komuniciranje je na razmeroma visoki ravni. Zelo dobra je tudi komunikacija z zunanjimi akterji, kot so na primer družinski člani, prijatelji in znanci, ki sooblikujejo tako notranje kot zunanje komuniciranje med zaposlenimi; 
- glede na skupino orodij je na prvem mestu najbolj uporabljena osebna komunikacija, sledijo ji elektronska in pisna komunikacija, spletne strani ter na petem mestu notranja glasila;

- med ključne pomanjkljivosti uvrščajo notranjo komunikacijo, ki je usmerjena predvsem v delovna navodila, drugih vsebin ni. Informacije niso pravočasne in kakovostne, prej netočne in zavajajoče;

- kot ključne izboljšave predlagajo zaposleni več komuniciranja na neformalni ravni (srečanja z vodstvom zunaj delovnega okolja, prostočasne aktivnosti ipd.), izboljšanje sistema povratnih informacij in nadgradnjo informacijskih orodij;

- na vsebinski ravni si zaposleni želijo več kadrovskih informacij, strateških vsebin, povezanih z obrambnim sistemom, več vsebin zunaj dogajanja SV ter korektno in sprotno obveščanje.

\subsection{Kako komuniciranje $\mathrm{z}$ javnostmi SV ocenjujejo predstavniki medijev}

Ugotavljali smo, kako pogosto mediji spremljajo dogajanje v SV. Dobili smo podatek, da 23 odstotkov vseh, ki so vprašalnik izpolnili, to počne vsak dan, 27 odstotkov enkrat na teden, 15 odstotkov enkrat na mesec in 35 odstotkov občasno.

Na vprašanje, kje dobijo največ informacij o SV, so na prvo mesto uvrstili različne vire na spletu, na drugo uradne predstavnike za odnose z javnostmi v SV, na tretje radio, televizijo in časopise ter na četrto mesto uradne spletne strani SV in ministrstva. Na vprašanja, ali je slovenska javnost prek medijev dovolj obveščena o poslanstvu in nalogah SV, o aktualnih dogodkih in nalogah v tujini, je 54 odstotkov vprašanih odgovorilo pozitivno in 46 odstotkov negativno.

Kakovost informacij o SV, ki se pojavljajo v slovenski javnosti, je bila po posameznih merilih ocenjena, kot je prikazano v grafu 1.
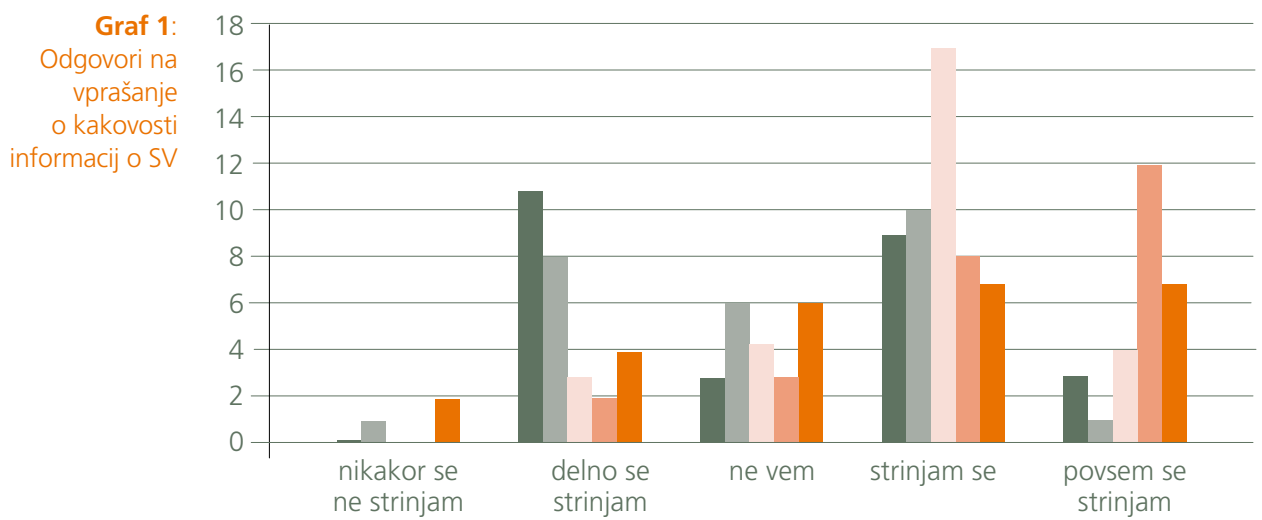

Info. je dovolj

so točne

so aktualne

pomembne za slov. javnost

pomembne za splošno varnost v regiji 
Pri vsebinah, povezanih s SV, ki najbolj zanimajo slovensko javnost, so se predstavniki medijev največkrat odločili za poslanstvo in naloge SV v mednarodnih operacijah in na misijah. Na drugem mestu so izbrali pomoč prebivalstvu v okviru nalog zaščite in reševanja, na tretjem izredne dogodke ter na četrtem civilno-vojaško sodelovanje. Sledijo življenje in delo v vojašnicah na petem mestu, na šestem vojaško urjenje in izobraževanje ter na zadnjem, sedmem mestu, vojaške vaje.

Na vprašanje, o katerih vsebinah bi bilo dobro več poročati, so vprašani označili in razvrstili vse prej naštete vsebine po enakem vrstnem redu glede na pomembnost. Med predloge pa so zapisali, da bi SV morala:

- v sodelovanju z RTV Slovenija po vzoru drugih držav poskrbeti za predvajanje dokumentarnih oddaj o delu in življenju v vojašnicah;

- nameniti več pozornosti doseganju svoje pozitivne podobe v javnosti;

- slovensko javnost bolje obveščati o porabi proračunskega denarja, ker jo to zelo zanima.

Ocena dela zaposlenih na področju odnosov z javnostmi po posameznih merilih je prikazana $\mathrm{v}$ grafu 2 .

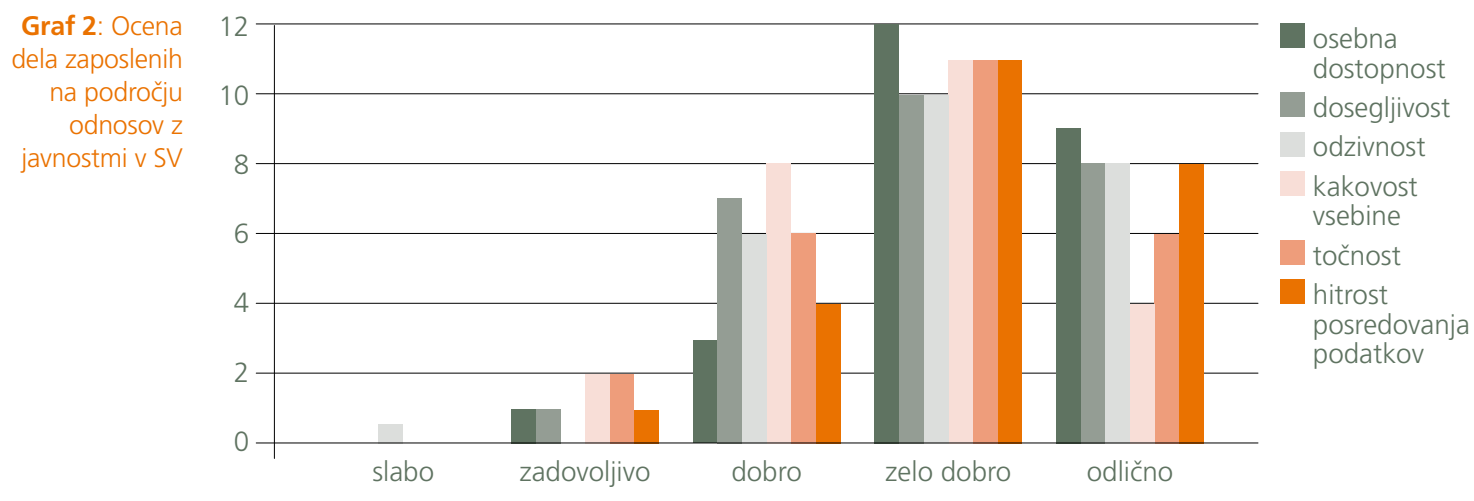

Predstavniki medijev so kot prvi vir za pridobivanje informacij o SV izbrali različne spletne strani. Ocena spletnih strani ministrstva je prikazana v grafu 3. 


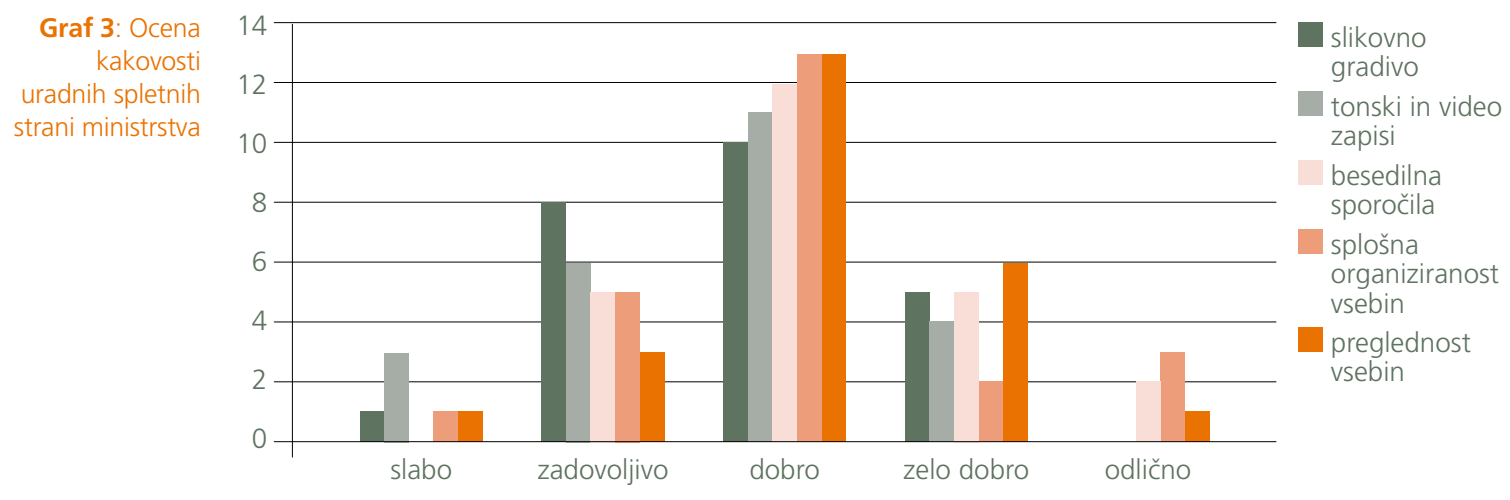

Med predlaganimi vsebinami za obogatitev spletnih strani so vprašani v rubriki odprtega tipa predlagali več poudarka predstavitvi posameznikov, na primer poveljnikov, odlikovancev in enot ter slikovnemu gradivu iz mednarodnih operacij in $\mathrm{z}$ misij.

Predstavniki za odnose z javnostmi za predstavnike slovenskih medijev priložnostno organiziramo obiske pripadnic in pripadnikov SV v mednarodnih operacijah in na misijah. Zanimalo nas je, kako pogosto se predstavniki medijev v vzorcu udeležujejo takih potovanj.

Enkrat se je takega obiska udeležilo 31 odstotkov vprašanih, dvakrat 38 odstotkov, večkrat 23 odstotkov, nikoli pa 42 odstotkov.

Da je taka potovanja treba organizirati večkrat, je menilo 85 odstotkov vprašanih.

\subsection{Strokovni in akademski pogled na kakovost odnosov z javnostmi v SV}

Projekt Zaupanje javnosti v SV je bil izveden v sodelovanju z revijo Obramba. Junija 2013 je CJM objavil povsem sveže rezultate meritev javnega mnenja, po katerih je SV ponovno na prvem mestu po zaupanju v javne institucije tako kot že januarja 2013 in v merjenjih prejšnja leta.

Kot je komentirala Garbova (2013, str. 8), se predstavniki SV ${ }^{10}$ radi v javnosti pohvalijo kot zaupanja vredna institucija, hkrati pa je spomnila, da so oborožene sile v demokratičnih državah praviloma na vrhu lestvic zaupanja javnosti, pri čemer je to zaupanje bistveno višje ${ }^{11}$ kot v Sloveniji, kjer je delež zaupanja približno 50odstoten. Na lestvici 31 držav imata manjši delež kot Slovenija samo še dve državi.

\footnotetext{
${ }^{10}$ Garbova se je oprla na intervjuje načelnikov GŠSV, generalmajorja Alojza Šteinerja in brigadirja Dobrana Božiča.

"Leta 2010 je bilo zaupanje v oborožene sile evropskih držav naslednje: Nemčija $70 \%$, Grčija 67 \%,

Francija $71 \%$, Italija $65 \%$, Avstrija $72 \%$, Estonija $80 \%$, Slovaška $72 \%$ in Madžarska $57 \%$.
} 


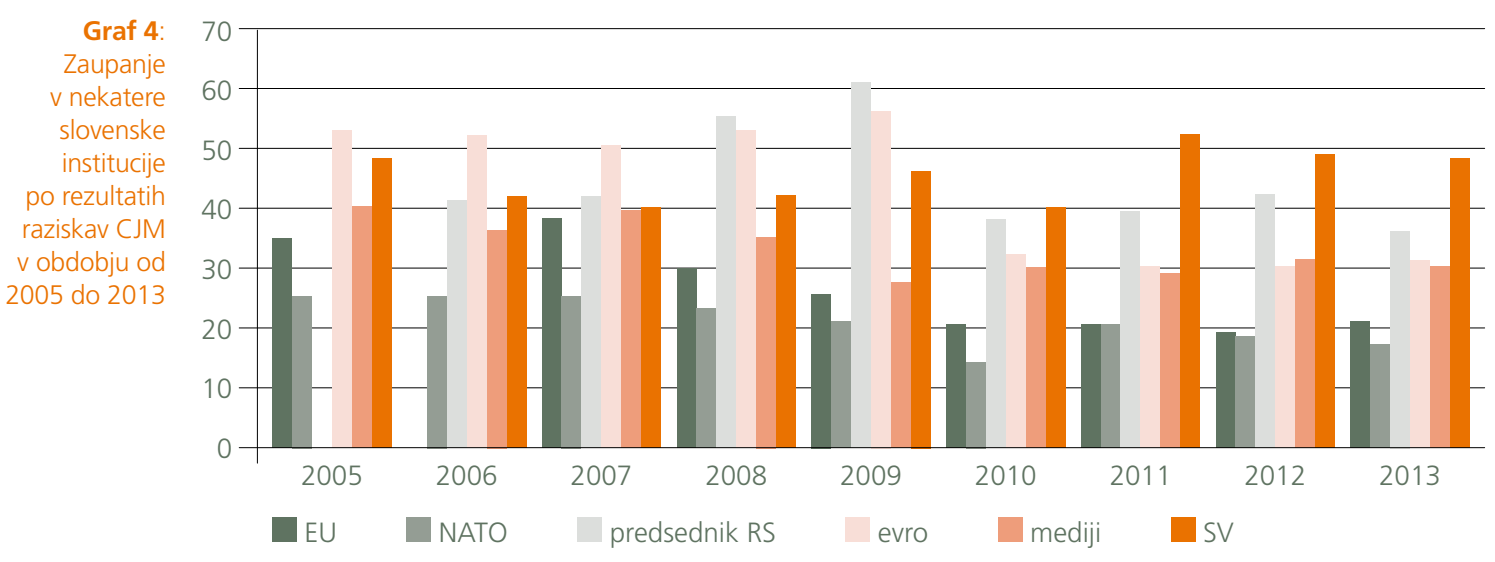

Vir: http://www.cjm.si/node, 18. 9. 2012.

V nacionalnem smislu pa Vuga izpostavi dejstvo, da javnost sicer podpira SV in njeno delovanje v MOM, a le, dokler vse poteka po načrtu, dokler ni izgredov, ranjenih in mrtvih (Vuga, 2013). Brankovič je izpostavil dejstvo, da ima SV veliko strokovnjakov s posebnimi vrstami znanja, ki bi jih lahko pogosteje delila s slovensko javnostjo, hkrati pa ima veliko priložnosti, ki jih ne izkoristi dovolj. Pri tej presoji se opira na ameriške izkušnje promoviranja vojske (Brankovič, 2013, st. 10). Kocjan pravi, da je vojska v javnem političnem diskurzu najpogosteje »nebodigatreba«, kateremu se v javnofinančni krizi naprej odvzamejo sredstva, ker je pač vse treba najprej preizkusiti na vojski, včasih pa bi vojsko kar ukinili. Zaradi tega je razmeroma visoka in stalna podpora vojski pravzaprav paradoks. Kocjan nadaljuje, da slovenska javnost zelo dobro loči med tem, kaj vojska v svojem bistvu je, in kakšni so politični vplivi nanjo (Kocjan, 2013, str. 11). Moč SV je v njenem tihem delu doma, za aktivnosti v MOM vedo le redki, nikakor pa ne tisti, ki jih zanima samo to, kaj se dogaja do konca domače ulice (Tepina, 2013, str. 12). Izkušenj na področju odnosov z javnostmi je bil posebej vesel Krajner, ki je kot predstavnik agencije Pristop s SV sodeloval pri medijski kampanji Ponosni nase. Pravi, da se tisti, ki so zaposleni v gospodarstvu, lahko učijo komuniciranja od SV, saj ta ne sledi slepo komunikacijskim trendom, temveč jih oblikuje (Krajner, 2013, str. 7).

\section{RAZPRAVA}

Na podlagi opisanih projektov lahko v SV notranjo javnost razdelimo na dve ciljni skupini. V prvo uvrščamo zaposlene z manj delovne dobe, torej mlajše generacije s pogodbo o zaposlitvi za določen čas, ki jih najbolj zanimajo njihov status v sistemu, plača in možnosti, kako to plačo zaslužiti, kako napredovati, se dodatno izobraziti in usposobiti za nove naloge in priložnosti ter še posebej, kako podaljšati pogodbo. 
Ta skupina gradi svojo profesionalno vojaško kariero in zanima jo vse, kar je s tem povezano. V drugo skupino spadajo zaposleni z daljšo delovno dobo, s pogodbami o zaposlitvi za nedoločen čas in z logiko delovanja javnih uslužbencev. Večina ima višjo stopnjo izobrazbe, spremlja aktualno dogajanje doma in po svetu ter želi vedeti več o aktualnih tokovih in prihodnjih spremembah na varnostno-obrambnem področju. Ti se počutijo bolj povezani z obrambnim sistemom, mu bolj pripadajo, zanima jih, kaj se dogaja drugim zaposlenim na osebni ravni in želijo biti aktivni ustvarjalci prihodnosti $\mathrm{v}$ sistemu

Neodvisno od tega pa si vsi želijo aktualnih in korektnih informacij. Posebej zanimivo $\mathrm{v}$ dobljenih rezultatih je, da si zaposleni želijo vedeti več o posameznikih znotraj sistema, kot pa o vodilnih. Zanimajo jih izkušnje drugih pri opravljanju nalog v tujini, v MOM, na vojaških izobraževanjih in usposabljanjih.

Elektronska komunikacija in uporaba spletnih strani sta poleg osebnega komuniciranja zelo uporabljeni orodji, zato je treba v prihodnosti takemu načinu komuniciranja nameniti več pozornosti v vsebinskem in tehničnem smislu.

Vse to se je potrdilo tudi na primeru vrednotenja komuniciranja z zunanjimi javnostmi oziroma s predstavniki medijev. Tudi ti uporabljajo predvsem osebno komunikacijo, a je zanje enako pomembna tudi pravočasna in korektna informiranost na spletu. Kot so pokazali rezultati, imajo spletne strani ministrstva, tako za notranjo javnost (Infotočka) s povprečno oceno 2,8 in zunanjo javnost s povprečno oceno 3, v razponu od 1 do 5 še veliko odprtih možnosti in priložnosti, kako javnostim ponuditi več in bolje.

Na primeru predstavnikov medijev, novinarjev in akademikov smo ugotovili, da tudi slovensko (zunanjo) javnost lahko razdelimo na dve cilji skupini. Tako v prvo zagotovo spadajo večje nacionalne medijske hiše ter akademski krogi. Zanimajo jih informacije o SV na splošno, še posebej pa vsebine strateškega pomena, kot so na primer financiranje obrambnega sistema in poraba sredstev v njem, načrtovanje aktivnosti na obrambnem področju in mednarodno sodelovanje, postopki sprejemanja dolgoročnih odločitev, predvideni vložki v sistem ter prihodnje koristi za posameznika in predvsem državo. Sogovorniki v tej skupini so strokovnjaki, zahtevni v svojih pričakovanjih, redno spremljajo dogajanja, so analitični in kritični v svojih interpretacijah. Predstavniki za odnose z javnostmi v SV se jim morajo posvetiti v celoti, torej biti odzivni, korektni in profesionalni.

V drugo skupino uvrščamo lokalne medije. Ti navadno niso pozorni na strateške odločitve, temveč jih zanimata lokalno okolje in življenje v njem. Tako je SV zanimiva zanje v okoljih, kjer so objekti SV, še posebej vojašnice in zaposleni v njih. Tam najbolj pride do izraza tako imenovano civilno-vojaško sodelovanje in pa seveda to, da so zaposleni v SV tudi sestavni del lokalnega prebivalstva in nenehno prisotni v tem okolju. Zanimajo jih izkušnje posameznikov in posebnosti njihovega poklica, vpetost takega posameznika v družbo in podobne sociološke vsebine. 
Komentar Garbove o primerjavi zaupanja splošne javnosti v SV glede na zaupanje v oborožene sile drugih držav ne spremeni dejstva, da se SV pojavlja na prvih mestih po zaupanju glede na druge državne institucije v Sloveniji. Za te nismo preverjali primerjalnih podatkov v drugih državah. Za našo sklepno oceno je pomembno vedeti tudi, kakšen je delež tistih, ki SV ne zaupajo. Tudi po tem merilu je SV na prvem mestu - po najmanjšem deležu.

Sklep Delež zaposlenih z daljšim delovnim stažem izraža podobna stališča in pričakovanja na področju odnosov z javnostmi kot splošna slovenska javnost. So previdni, želijo biti obveščeni in sooblikovati svojo prihodnost kot sestavni del slovenske javnosti in obrambnega sistema. Zanimajo jih strateške odločitve, dogajanje v oboroženih silah v mednarodnem okolju in vpetost SV v splošno družbeno okolje. So kritični, tako kot predstavniki večjih medijskih hiš, ki so specializirani za področje obrambe ali nacionalnovarnostnega sistema.

Po drugi strani imamo mlajše generacije zaposlenih, ki vojaštvo razumejo strogo profesionalno, vedo, zakaj so prišli v sistem, kaj hočejo in kako bodo to dosegli. Vse to kažejo tako v SV kot tudi v domačem okolju. Tako sta ugotovila Tepina in Kocjan, pa tudi sami so se tako opredelili v vprašalnikih, ki so jih izpolnili.

V preglednici 2 so strnjene ključne ugotovitve evalvacije v odnosu do posameznih javnosti in po posameznih projektih, ki so hkrati tudi ciljne skupine za komuniciranje. Nekatere ugotovitve smo sproti upoštevali tudi pri našem delu. Letos smo okrepili pojavljanje SV na socialnih omrežjih in tako dosegli mlajše generacije v delu notranje in zunanje javnosti. Tako smo se posredno izognili administrativnim, varnostnim in informacijskih oviram, ki so preprečevale bolj dinamično komuniciranje prek uradnih spletnih strani SV in MO.

Med zahtevnejše naloge za komuniciranje v prihodnje zagotovo spadajo aktualne in strateške vsebine, za katere je zanimanje večje od ponudbe.

Znanja in izkušenj je v SV dovolj. V prihodnje bomo morali najti dodatne načine za spodbujanje nastajanja pisnih, slikovnih in avdio vsebin. Navedeno je povezano $\mathrm{s}$ kadrovskimi in finančnimi viri, potrebnimi za različne oblike usposabljanja, nakup tehnične in informacijske opreme ter organizacijo različnih dogodkov, zanimivih za javnost. 


\begin{tabular}{|c|c|c|c|}
\hline \multirow{4}{*}{$\begin{array}{r}\text { Preglednica } \\
2: \text { Pristopi } \\
\text { k evalvaciji } \\
\text { po Rühlu, v } \\
\text { povezavi s } \\
\text { posameznimi } \\
\text { projekti na } \\
\text { področju } \\
\text { odnosov z } \\
\text { javnostmi, ki } \\
\text { smo jih izvedli } \\
\text { v SV, in s } \\
\text { predlaganimi } \\
\text { izboljšavami }\end{array}$} & $\begin{array}{l}\text { Pristopi k evalvaciji } \\
\text { po Rühlu }\end{array}$ & Notranja javnost & Zunanja javnost \\
\hline & laični pristop & $\begin{array}{l}\text { Notranji spletni portal Infotočka: } \\
\text { - izboljšati celostno podobo } \\
\text { portala, aktualizirati novice, } \\
\text { - izboljšati kakovost s predlaganimi } \\
\text { vsebinami. }\end{array}$ & $\begin{array}{l}\text { Zaupanje javnosti v SV: } \\
\text { - izboljšati spletne strani MO, } \\
\text { - izboljšati količino in kakovost avdio in } \\
\quad \text { video zapisov. }\end{array}$ \\
\hline & strokovni & $\begin{array}{l}\text { Komuniciranje z notranjo javnostjo SV: } \\
\text { - izboljšati osebno komunikacijo, } \\
\text { - izboljšati kakovost komunikacije s } \\
\text { predlaganimi vsebinami, } \\
\text { - komentirati aktualne teme o SV, ki se } \\
\text { pojavljajo v javnosti, } \\
\text { - ponuditi več strateških tem, } \\
\text { - izboljšati dinamiko publikacij/glasil SV. }\end{array}$ & $\begin{array}{l}\text { Komuniciranje SV s predstavniki } \\
\text { medijev: } \\
\text { - izboljšati spletne strani SV, } \\
\text { - izboljšati količino in kakovost avdio in } \\
\text { video zapisov, } \\
\text { - več pozornosti nameniti lokalnim } \\
\text { medijem. } \\
\text { Zaupanje javnosti v SV: } \\
\text { - športne in humanitarne dogodke bolj } \\
\text { povezati z javnostjo in vabiti medije } \\
\text { - na dogodke, ki jih organizirajo } \\
\text { strokovni krogi, vključiti tudi } \\
\text { strokovnjake iz SV }\end{array}$ \\
\hline & akademski & & $\begin{array}{l}\text { Zaupanje javnosti v SV: } \\
\text { - v dogodke, ki jih organizirajo } \\
\text { akademski in drugi strokovni krogi, } \\
\text { vključiti tudi strokovnjake iz SV }\end{array}$ \\
\hline
\end{tabular}

Kako kakovostno je torej področje dela odnosov z javnostmi v Slovenski vojski?

Glede na okoliščine, ki sta jih predstavili Garb in Vuga, ter ob upoštevanju zaupanja slovenske javnosti v druge državne institucije, lahko sklenemo samo, da zagotovo na zelo visoki ravni.

Nagrada za medijsko kampanjo je potrditev navedenega. Predstavniki medijev so razmeroma zadovoljni s predstavniki za odnose z javnostmi v SV. Predloge in pobude imata tako zunanja kot notranja javnost. Možnosti za izboljšanje kakovosti komuniciranja je še veliko. Pa je res tako?

Rezultati, upoštevani v tej evalvaciji, so nastali v zadnjih treh letih in pol in kažejo na stanje v preteklosti. Ugotovitve vsake evalvacije pa so imperativ za prihodnost. Zmanjševanje virov na vseh področjih delovanja države, zmanjševanje obrambnega proračuna, plač v javnem sektorju, števila zaposlenih ... in seveda, odnos slovenske javnosti do SV.

V prihodnje bomo še naprej iskali kreativne rešitve. Žal je slogan »z manj je več« preživet in pride čas, ko je treba povedati, da ni tako. 
Izzivov na področju dela odnosov z javnostmi v SV je še veliko. Nekaj novosti so predlagali zaposleni, nekaj drugi udeleženci v evalvaciji, največ pa jih bo nastalo sproti. In slovenska javnost bo ponovno tista, ki bo povedala, komu in koliko zaupa.

\section{Literatura}

1. Bennet, J., 2003. Evaluation Methods in Research. London, New York: Continuum Research Methods.

2. Brankovič, J., 2013. Smo danes res zaslužili 1,08 milijona? Revija Obramba, julij 2013, str. 10. Defensor, d. o. o.

3. Edmonds, M.,1988. Armed Services and Society, Leicester Unversity Press, Leicester.

4. Garb, M., 2013. Javno mnenje o Slovenski vojski dobro, a v mednarodno primerjalni luči slabše. Revija Obramba, julij 2013, str. 8. Defensor, d. o. o.

5. Hallahan, K., Holtzhausen, D., Van Ruler, B., Verčič, D., Sriramesh, K., 2008. Teorija in praksa, 6/2008, str. 628-662. Fakulteta za družbene vede, Ljubljana.

6. Huntington, S. P., 1957. The Soldier and the State, The Theory and Politics of CivilMilitary Relations. New York: Vintage Books.

7. Jelušič, L., 1997. Legitimnost sodobnega vojaštva. Fakulteta za družbene vede. Ljubljana.

8. Jelušič, L.,2003. Slovenian Public Opinion on security, defence and military issues. $V$ Marie Vlachova (ur.). The poblic image of defence and the military in Central and Eastern Europe, 182-200. Geneva: Centre for the Democratic Control of the Armed Forces (DCAF): Belgrade: Centre for Civi-l Military Relations (CCMR)

9. Kocjan, A., 2013. Ambasadorji si ne morejo privoščiti kiksov. Revija Obramba, julij 2013, str. 11. Defensor, d. o. o.

10. Korez, S., 2008. Slovenska vojska kot skupnost in njeno komuniciranje z javnostjo. Specialistično delo. Fakulteta za socialno delo, Ljubljana.

11. Krajner, A., 2013. Tisti, ki smo zaposleni v gospodarstvu, se lahko učimo od komuniciranja Slovenske vojske. Revija Obramba, julij 2013, str. 7. Defensor, d. o. o.

12. Prezelj, I., 1997. Komuniciranje med oboroženimi silami in javnostmi. Teorija in praksa XXXIV (6): str. 1020-1034.

13. Rühl, M., 2008. Public Relations Methodology Should we bother (If it exists)?. Vvan Ruler, Betteke; Tkalac Verčič, Ana; Verčič, Dejan, Public relations metrics Research and evaluation. Routlege, 2008.

14. Rus, V., Toš, N., 2005. Vrednote Slovencev in Evropejcev, Analiza vrednotnih orientacij Slovencev ob koncu stoletja. Fakulteta za družbene vede. IDV, CJMMK, str. 333-369.

15. Serajnik Sraka, N., 2008. Vrednotenje v odnosih z javnostmi. Teorija in praksa, 6/2008, str. 870-876. Fakulteta za družbene vede, Ljubljana.

16. Tepina, J., 2013. Tudi če si najmanjši, ni treba, da govoriš, kako si dober, da ljudje to prepoznajo. Revija Obramba, julij 2013, str. 12. Defensor, d. o. o.

17. Van Dyk, M., Verćič, D., 2009. Public relations, public diplomacy and strategic communication: An international model of conceptual convergence. V Sriramesh, Krishnamurty, Verčič (ured.): The global Public Relations Handbook Revised Edition: Theory, Research, and Practise, str. 822-842. London, New York.

18. Verčič, D., 1995. Odnosi z javnostmi: nastanek, zgodovina in teorije. Magistrsko delo. Fakulteta za družbene vede, Ljubljana.

19. Verčič, D., 1999. Odnosi z javnostmi v Evropi, Ljubljana. Pristop.,

20. Vuga, J., 2013. Sprejemljivost mednarodnih operacij in misij dokler ne postane »vroče«. Revija Obramba, julij 2013, str. 9. Defensor, d. o. o. 



\section{VOJSKA Z VIDIKA TEMELJNIH POJMOV SOCIALNE PSIHOLOGIJE}

\section{MILITARY FROM THE POINT OF VIEW OF BASIC SOCIAL PSYCHOLOGY TERMS}

Povzetek Namen tega prispevka je predstaviti temeljne pojme socialne psihologije in z njimi na podlagi izkušenj, pridobljenih v Slovenski vojski, pogledati vojaško organizacijo. Vojska je organizacija, v kateri ima skupina večji pomen kot posameznik. Pogled na vojaško organizacijo prek temeljnih pojmov socialne psihologije se zdi logičen korak, ki lahko prinese uporabna nova spoznanja za obe področji, tako za socialno psihologijo kot za vojaški sistem. Povezava je izpeljana na podlagi izkušenj, pridobljenih z delom v Slovenski vojski.

V prvem delu so predstavljeni temeljni koncepti socialne kognicije: teorije pozornosti in kognitivnih shem, stereotipi, stališča in teorija pripisovanja. V drugem delu sledijo temeljni koncepti, vezani na skupino, kot so interakcija znotraj skupine s procesi posnemanja, sugestije, identifikacije in socialnega pritiska, ter koncept socialne moči.

V zadnjem delu z uporabo teh pojmov orišemo vojaško organizacijo, natančneje Slovensko vojsko, in sicer njeno hierarhično ureditev, policentrično in asimetrično razporeditev moči ter prepletanje formalne in neformalne moči v njenem vsakodnevnem delovanju.

Ključne besede

Abstract

\section{Vojska, socialna psihologija, socialna kognicija, skupina.}

The aim of this article is to present basic concepts of social psychology and to take a closer look at a military organization based on the experiences gained within the Slovenian Armed Forces.

In military organizations, the group is of greater importance than the individual. A closer look at a military organization through the prism of those basic social psychology concepts seems like a logical step that can lead to useful new knowledge in, both, social psychology and the military system. The link between the two is derived on the basis of experience acquired through the employment in the Slovenian Armed Forces. 
The first part of the article focuses on basic concepts of social cognition, such as the theories of attention, cognitive schemas, stereotypes, attitudes and theories of attribution.

In the second part of the article we focus on basic concepts related to groups, such as interaction with the processes of imitation, suggestion, identification, social pressure and the concepts of social power,

In the last part we use these key concepts to illustrate a military organization, notably the Slovenian Armed Forces, its hierarchical structure, polycentric and asymmetric distribution of power and the intertwining of formal and informal power in its daily routine.

\section{Key words Military, social psychology, social cognition, group.}

Uvod Namen tega prispevka je predstaviti temeljne koncepte socialne psihologije in poskusiti opisati njihovo aplikativno vrednost za vojaški sistem. V vojaški organizaciji je nosilec večine nalog vojaška enota, ne glede na to, ali gre za naloge v miru, za klasične bojne naloge ali mirovne operacije.

Dobro delovanje enote je torej za vojaški sistem ključnega pomena, saj povečuje verjetnost uspešno opravljene naloge. Vojska je organizacija, v kateri ima skupina, torej vojaška enota, večji pomen kot posameznik.

Predpostavimo, da poznavanje procesov, ki vplivajo na medosebno interakcijo in jo določajo, ter poznavanje skupinskih procesov znotraj skupine in med skupinami pripomoreta $\mathrm{k}$ boljšemu delovanju skupine, in da je skupina oziroma enota temeljna celica, ki v vojaškem sistemu opravlja naloge. Iz naštetega lahko sklepamo, da poznavanje dognanj socialne psihologije lahko pripomore k večji učinkovitosti vojaškega sistema.

\section{SOCIALNA KOGNICIJA}

Podlaga za delovanja posameznika v socialnem okolju so procesi zaznavanja in predelave informacij. V socialnem kontekstu jih opredeljujemo z imenom socialna kognicija. M. D. Lieberman navaja (v prostem prevodu): »To, kdo smo kot ljudje, je v veliki meri povezano s tem, kar se dogaja med našimi ušesi. To, kar se dogaja med našimi ušesi, je močno povezano s socialnim svetom, znotraj katerega potujemo, smo v njem aktivni in se nanj odzivamo.« (2010, str 143) Povedano drugače, nihče od nas ni v vakuumu, vsi smo del nekega okolja. Dogajanje zunaj je povezano z dogajanjem znotraj nas. Vse skupaj pa določa, kdo kot posameznik smo. Ljudje smo nenehno izpostavljeni toku informacij, ki izvirajo iz nas in okolja. Informacij, $\mathrm{s}$ katerimi se v tem okolju srečujemo, ne sprejemamo samodejno in naivno kot npr. kamera ali diktafon, prav tako jih ne prenesemo v naš spomin neposredno, nespremenjenih in točno takšnih, kot so bile sprejete v zaznavnem sistemu (Hamilton, 2005). Pri njihovem prenosu in predelavi pri človeku sodeluje več procesov, eden pomembnejših, ki služi kot podlaga drugim, je pozornost. 


\subsection{Pozornost}

S pozornostjo se ukvarjajo predvsem raziskovalci s področja kognitivne psihologije in širšega področja kognitivnih znanosti.

Definirati, kaj je pozornost, je za psihologijo še vedno težava. V zgodovini psihologije je bilo več različnih definicij ali opredelitev, kaj pozornost je. Tako na primer James (1890, po Styles, 2006) pravi, da je vsem jasno, kaj je pozornost, in se vsebine ne dotika. Shiffrin (1988, po Styles 2006) pravi, da je pozornost uporabljena za vse vidike človeških zaznav, ki jih lahko posameznik nadzoruje in so povezane z omejenimi zmogljivostmi in sredstvi človeškega zaznavanja. Pashler (1999) pa v knjigi Psychology of attention zapiše, da za svoje izhodišče jemlje predpostavko, da nihče ne ve, kaj je pozornost.

Kljub težavam z definicijo obstaja splošen konsenz, da je pozornost povezana z omejenostjo človeškega zaznavnega aparata in njegovih procesov (Styles, 2006).

Človekov zaznavni aparat je končen, ima svoje omejitve. Tako smo na primer omejeni pri razponu tonov, ki jih lahko zaznamo, ali pa z valovno dolžino svetlobe, na katero se odzivajo naši čuti. Tudi če ostanemo znotraj omejitev, ki jih imajo naša čutila, je »informacij v vsakem trenutku v okolju več, kot jih človekov zaznavni aparat lahko predela« (Ule, 2009; Styles, 2006). S procesi pozornosti naš zaznavni aparat opravlja funkcijo »vratarja« (Hamilton, 2005). Nikoli ne moremo biti pozorni na vse, kar se dogaja v našem okolju. Bolj ko je to okolje bogato, več je informacij, ki se »borijo« za vstop v našo zavest. Ker pa lahko zavestno obdelamo le omejeno količino podatkov, potrebujemo filter, ki to količino zmanjša. Vlogo tega filtra ima pozornost. Procesi pozornosti, s katerimi filtriramo podatke, potekajo tako z zavestnim usmerjanjem kot tudi samodejno (Styles, 2006). To, da so nekateri procesi samodejni, pomeni, da imamo svojo pozornost le delno pod nadzorom volje. Tako lahko dražljaji večje moči (npr. glasen pok, močan blisk) samodejno pritegnejo našo pozornost, tudi če smo jo zavestno usmerjali drugam (npr. v pogovor, opazovanje neke osebe itn.).

Socialno okolje je informacijsko zelo bogato, kot rečeno pa smo pri količini podatkov, ki jih lahko hkrati predelujemo, omejeni. To pomeni, da obstaja velika verjetnost, da nam bodo nekatere informacije tudi ušle. Seveda pa niso vsi podatki enako pomembni. Tako je na primer za voznika podatek, da na semaforju gori rdeča luč, pomembnejši kot ta, katera pesem se vrti po radiu. Za vojaka je podatek, da je v bližini glasno počilo, pomembnejši od tega, da se nadrejeni pogovarja z njim. Uspešnost naše interakcije z okoljem je močno odvisna od tega, ali je naša pozornost usmerjena na prave, ključne informacije, ali so »filtri« v določeni situaciji torej »pravilno nastavljeni«.

Našo pozornost vodi in usmerja kognitivni aparat (Hamilton, 2005), še posebej pomembno vlogo pri njenem usmerjanju pa imajo kognitivne sheme. 


\subsection{Kategorizacija in kognitivne sheme}

Bruner (2005) navaja, da zaznava inherentno vsebuje akt kategorizacije. Vse, kar zaznavamo, uvrščamo v kategorije. Kategorizacija pomeni razvrščanje dogodkov, stvari in dražljajev v skupine oziroma kategorije (Ule, 2009), ki so lahko zelo široke. Tako lahko na primer predmete uvrstimo v kategorijo nevarnih ali nenevarnih. Lahko pa so kategorije zelo specifične, kot na primer opazovanje silhuet letal in njihovo razvrščanje v posebne podkategorije po vrstah letal. Šele v procesu kategorizacije objekti in dogodki dobijo svoj pomen (Hamilton, 2005). Dokler dražljaja ne kategoriziramo, ostaja za nas neznanka.

Kategorije vodijo do kompleksnejših struktur, ki jih imenujemo kognitivne sheme. Kognitivne sheme so abstraktne strukture znanja, zgrajene na pridobljenih dražljajih, ki zagotavljajo ciljno usmerjeno obdelavo informacij (Thorndyke, 1979; po White in Carlston, 1983). Vse, kar ljudje zaznavamo, poskušamo povezati v smiselne celote oziroma strukture, ki nam nato pomagajo pri zaznavanju novih dražljajev. S kognitivnimi shemami si osmislimo svet, ki nas obdaja. Pogosto nam že ustvarjene kognitivne sheme pomagajo določiti, kateri elementi oziroma informacije so bolj in katere manj pomembne. Temu ustrezno usmerjamo tudi našo pozornost. Tako kot za pozornost tudi za kognitivne sheme velja, da lahko ti procesi potekajo zavestno ali samodejno, torej ne da bi se jih neposredno zavedali. Na splošno velja, da pozornost usmerjamo na informacije, ki so najbolj pomembne (Kenarick in Petersen; po White in Carlston, 1983). Toda katere so najbolj pomembne in po katerih merilih to določimo? V socialni situaciji so to informacije, ki lahko neko shemo ali pričakovanje potrdijo ali ovržejo (Bower, Black in Turner; po White in Carlston, 1983), in informacije, ki še niso uvrščene v sheme (White in Carlston, 1983). Povedano drugače, v neki situaciji smo najprej pozorni na stvari, ki pomagajo določiti, ali je situacija skladna z našimi pričakovanji ali ne. Za primer si lahko predstavljamo vojaka, ki je zamenjal enoto. Ob prihodu v novo enoto bo pozoren na stvari, ki mu bodo povedale, kako se ta enota razlikuje od njegove prejšnje. Ali se postrojitvena pravila izvajajo enako ali pa so vseeno opazne razlike. Ali je na primer pozdravljanje $\mathrm{z}$ roko dosledno $\mathrm{v}$ rabi ali pa je mogoče sprejemljivo tudi pozdravljanje samo $\mathrm{z}$ glasom. Na podlagi zaznanega bo vojak prilagodil svoje vedenje.

Še posebej pa smo v novi situaciji pozorni na elemente, ki so nam neznani. Neznanka v okolju pomeni morebitno nevarnost.

Ljudje smo nagnjeni $\mathrm{k}$ temu, da nove informacije prilagajamo obstoječim shemam (Ule, 2009), v okolju iščemo informacije, ki se ujemajo z našimi shemami. Ko neko situacijo uvrstimo v shemo, smo bolj pozorni na informacije, ki to prepričanje potrjujejo, tiste ki niso skladne s prepričanji, pa poskušamo prilagoditi oziroma uskladiti (White in Carlston, 1983).

Sheme nam ne služijo le pri določanju ključnih informacij, uporabljamo jih tudi za dopolnjevanje manjkajočih. Kot smo že napisali, smo ljudje omejeni pri tem, koliko podatkov lahko v določenem času obdelamo. To pomeni, da se pogosto znajdemo $\mathrm{v}$ 
položaju, ko ne moremo biti pozorni na vse, kar se okoli nas dogaja. Še več, dogaja se, da nam uidejo pomembne informacije. Da je tega čim manj, si pomagamo tudi s kognitivnimi shemami. Na podlagi pričakovanj, ki izhajajo iz naših shem, informacijske praznine zapolnjujemo $\mathrm{z}$ informacijami iz sheme, ki smiselno pokriva to situacijo (Hamilton, 2005).

Vse povedano velja tudi v socialnem kontekstu in v socialnih zaznavah. Sheme, pozornost, zaznavanje in predelava informacij, vse to je prisotno, ko presojamo druge ljudi, sebe, odnose, skupine, skratka socialni svet okoli nas. Pomembno pa je tudi zavedanje, da ti procesi potekajo tudi pri drugih. Tudi drugi presojajo nas, naše odnose, našo skupino, enoto.

Poveljnik oddelka ima oblikovane vsaj nekatere sheme o svoji enoti, vojakih in nadrejenih, enako verjetno velja za vojake in njihove sheme o poveljniku oddelka in oddelku.

Vojaška enota je tako prostor, znotraj katerega se srečuje množica individualnih predstav, pričakovanj in predvidevanj, ki se navezujejo na enoto in njene pripadnike, pa tudi na širšo strukturo, znotraj katere je enota.

Tako se lahko znotraj majhne enote, kot je oddelek, pojavljajo zelo različne kognitivne sheme dobrega vojaka, dobrega poveljnika, dobrega oddelka. To pomeni, da pripadniki znotraj majhne enote nekatere stvari vidijo zelo različno. To je povezano tako z razlikami v tem, katere so ključne informacije, in tem, kam posameznik usmerja svojo pozornost. Zelo pomembno je tudi, kako posamezniki zapolnijo informacijske vrzeli, ki so posledica omejitev pozornosti.

Kognitivne sheme nas v večini primerov privedejo do pravilnih sklepov. Brez tega se verjetno ne bi obdržale (Hamilton, 2005). Imajo pa tudi svoje pomanjkljivosti, zaradi katerih smo ljudje nagnjeni tudi k postavljanju napačnih sklepov oziroma napakam. Tako se lahko informacijske vrzeli napačno zapolnijo. Pogoste napake tako nastanejo na podlagi sklepanja iz stereotipov.

\subsection{Stereotipi}

Stereotipe lahko opredelimo kot podkategorijo kognitivnih shem. To so generalizirane povezave neke skupine lastnosti s celotno skupino ljudi (Ule, 2009, Dijksterhuis, 2010). Tako je lahko stereotipna predstava o vojaku nastala zato, ker se osebi $\mathrm{v}$ vojaški uniformi pripisujejo lastnosti, ki nimajo stvarne podlage, pa naj bodo to negativne lastnosti, kot je agresivnost, ali pozitivne, kot je lojalnost ali pogum.

Ustvarjanje stereotipov in uvrščanje vanje je v bistvu nezaveden proces (Dijksterhuis, 2010), kar pomeni, da so stereotipi zunaj našega zavestnega nadzora in da sami zelo težko vemo, kdaj so prisotni. 
Dunning in Sherman (1997) v svojih študijah odkrivata, da imajo generalizirane stereotipne predstave vpliv tudi na vedenje pri posameznikih, ki na zavestni ravni te stereotipe zavračajo. Kar pomeni, da lahko nekatere predstave deklarativno tudi zelo iskreno zavračamo, vendar naše vedenje kaže, da so te predstave v globljih, zavesti manj dostopnih strukturah še vedno prisotne. In kar je še pomembneje, na naše vedenje imajo močnejši vpliv kot naša zavestna prepričanja.

Vedenje, skladno z našimi stereotipnimi pričakovanji, lahko ima še dodatno pomembno posledico, saj lahko zares spodbudi stereotipno vedenje pri ciljni osebi (Dijksterhuis, 2010). Pričakovanje agresivnega vedenja pri nekom lahko povzroči naše agresivno vedenje, kar privede do agresivnega odziva in s tem do potrditve stereotipa, ki pa smo jo izsilili sami. Ljudje smo nagnjeni k temu, da vzdržujemo naše kognitivne sheme (Ule, 2009) in z njimi tudi naše stereotipe. To pomeni, da so stereotipi strukture, ki jih težko spreminjamo. Sheme se spremenijo ali prilagodijo le, ko so informacije dovolj močne in jih ni mogoče prilagoditi že obstoječim strukturam in tem strukturam celo nasprotujejo (Ule, 2009; Hamilton, 2005).

Sklepanje na podlagi stereotipov ima lahko zelo nevarne posledice. Več raziskav (Correl, Park, Judd in Wittenbrink, 2002) je pokazalo, kako lahko rasni stereotip nevarno vpliva na zaznavo in vedenje posameznika ali množice v posebni situaciji. V različnih simuliranih situacijah so pokazali, da je veliko večja verjetnost, da pri temnopoltem moškem, ki ima v roki orodje ali telefon, izurjeni opazovalci ta nenevarni objekt zamenjajo z orožjem. Zato je večja verjetnost, da se na temnopoltega moškega opazovalec odzove kot na nevarnega posameznika.

Mednarodno delovanje in večkulturni prostor sta postala stalnica, znotraj katere delujejo sodobne vojaške organizacije, tudi Slovenska vojska v tem ni izjema, saj deluje $\mathrm{v}$ mednarodnih poveljstvih in na mednarodnih misijah v kulturno zelo raznolikih okoljih. Za ta okolja je značilna kulturna, etnična, religiozna in spolna heterogenost. Prav tako najdemo podobno heterogenost tudi znotraj vojske. To je prostor, v katerem se lahko razvijejo in uveljavijo stereotipi.

\subsection{Stališča}

Tesno povezana s kognitivnimi shemami in stereotipi so stališča. Po Uletovi (2009) so stališča socialno pridobljene strukture. Zanje ni bioloških predispozicij. Definicij stališč je preveč (Banaji in Heiphetz, 2010), da bi jih v tem besedilu obravnavali. Relativno soglasje pa vlada okoli njihovega jedrnega elementa - vrednotenja (Banaji in Heiphetz, 2010). Crano in Prislin (2006; po Banaji in Heiphetz, 2010, str. 357) zapišeta, da so »/.../ stališča, vrednostne sodbe, ki združujejo in povzemajo /.../ kognitivne oziroma afektivne reakcije.« Poenostavljeno lahko rečemo, da so stališča naš »za« in naš »proti«.

Po klasičnih teorijah imajo stališča tri komponente: afektivno (čustva), kognitivno (prepričanje) in konativno (vedenje) (Banaji in Heiphetz, 2010). Sodobne teorije poudarjajo afektivno komponento kot tisto, ki prevlada nad drugima dvema (Banaji in 
Heiphetz, 2010). Bila naj bi lažje in hitreje dosegljiva kot kognitivna. Iz tega bi lahko sklepali, da ljudje nismo nujno racionalna bitja. Lavine, Thomsen, Zanna in Borgida (1998, po Banaji in Heiphetz, 2010) za predsedniške volitve v ZDA ugotavljajo, da so v primerih, ko so prepričanja in čustva v nasprotju, čustva boljši napovedovalec vedenja. Pri oblikovanju »za« ali »proti« imajo torej čustva pri ljudeh večji vpliv kot zaznave.

V povezavi stališč in socialnega presojanja se je pokazalo, da je v ospredju uporaba dveh dimenzij - dobrote oziroma topline (prijaznosti) in kompetenc (sposobnosti) (Banaji in Heiphetz, 2010). V ozadju pa je prepričanje, ki ga podpirajo empirični dokazi (Banaji in Heiphetz, 2010), da socialna interakcija zahteva odgovore na dve temeljni vprašanji. Prvo je, kako dober je človek, dober ali slab, meni naklonjen ali ne, drugo vprašanje pa je, kako kompetenten je ta človek oziroma kako učinkovit je v tem, kar dela. Odgovori na prvo vprašanje so hitreje dosegljivi (Banaji in Heiphetz, 2010) in imajo tudi večji vpliv na ustvarjanje stališč in naše vedenje.

Podobne dimenzije so se pokazale kot koristne tudi za delo v vojaški skupini (Malone, 2003). Ključni informaciji, ki ju potrebujemo za oceno vojaka (ne glede na čin) in njegov prispevek vojaški enoti, sta, kako motiviran je (ali je dober ali slab) in kako je usposobljen oziroma ali je kompetenten.

Če sledimo povedanemu, tudi v tem primeru velja, da je čustvena komponenta (ali je nekdo prijateljski ali sovražen, ali sodeluje ali ne) lažje dosegljiva in s tem pomembnejša kot kognitivna.

Tesno povezano s socialno presojo, kaj človek hoče in kaj zna oziroma zmore, je tudi pripisovanje vzrokov oziroma teorija pripisovanja (Hamilton, 2005).

\subsection{Teorija pripisovanja (atribucije)}

Teorija pripisovanja spada v področje tako imenovane naivne psihologije (Ule, 2009, Hamilton, 2005). Ljudje v svojem vsakdanjem življenju in medsebojnih stikih pripisujemo dogodkom okoli sebe različne vzročne povezave, osebam pripisujemo odgovornost za njihovo vedenje. Od tega, kako osebi pripišemo odgovornost za njeno vedenje, je odvisno, ali jo sprejemamo, nam je simpatična, ali pa jo zavračamo (Ule, 2009).

Procesi pripisovanja so tesno povezani s socialnimi zaznavami (Ule, 2009, Hamilton 2005). Heider (2005) je navedel na pomembno ločnico, ki se veže na vzročni vir. Nekateri vzroki za dejanja in vedenje so notranji, izhajajo iz človeka (osebnostne poteze, motivi, stališča itn.), drugi pa so zunanji, izhajajo torej iz okolja (socialni pritisk, situacijske omejitve in zahteve itn.).

Ljudje smo kot opazovalci pri pripisovanju odgovornosti pristranski (Hamilton, 2005). Ross (1977, po Hamilton, 2005) poroča o »izvorni napaki pripisovanja«. Pri presojanju vedenja drugih ljudi so opazovalci nagnjeni k precenjevanju notranjih 
vzrokov (motivov, osebnostnih potez itn.), hkrati pa so zelo »imuni« za prepoznavanje moči zunanjih dejavnikov, ki lahko vplivajo na vedenje v neki situaciji ali ga celo določajo. Poznejše študije so pokazale (Menon 1999; po Hamilton 2005, str. 286), da je »izvirna napaka pripisovanja« kulturno pogojena. V evropsko-ameriškem kulturnem krogu opazovalci pripisujejo vzroke vedenja notranjim vzrokom posameznika, v vzhodnoazijskem pa opazovalci vzroke vedenja bolj pripisujejo vplivom skupine.

\section{SKUPINA IN NJENE ZNAČILNOSTI}

\subsection{Značilnosti skupine oziroma vojaške organizacije}

Za socialno psihologijo je skupina temeljno področje raziskovanja, zato so se številni avtorji osredotočali na iskanje definicij posameznih značilnosti in notranje dinamike skupine. Metodološko so nekateri, kot npr. Krech in Crutchfield (1948; po Zvoneriviču 1985), uporabili interakcijo med posameznimi pripadniki za definiranje značilnosti skupine, drugi, npr. Cattel (1951; po Zvonariviču 1985), pa so se pri svojih definicijah osredotočali na funkcionalnost skupine v smislu zadovoljevanja potreb njenih članov. Bili so tudi poskusi združevanja obeh definicij (Gibb, 1954; po Zvonarevič, 1985). Na splošno v socialni psihologiji skupino pojmujemo kot zbir posameznikov, med katerimi obstaja interakcija, zaradi katere se vedenje in aktivnost posameznika spreminjata zaradi prisotnosti drugih članov skupine. Ob tem je treba poudariti, da fizična prisotnost drugih članov ni nujna (ni pogoj za oblikovanje skupine), ampak zadošča že zavest o pripadnosti skupini.

Sodobnejše teorije (Levine, 2006) govorijo o skupinskosti kot kontinuumu, ki se razteza med ekstremoma od neskupinskosti do skupine. Skupine torej ne obravnavajo kot ali je ali ni, temveč poskušajo skupino ljudi uvrstiti v kontinuum po tem, koliko je skupinskost pri njih izražena.

Za obravnavo skupine znotraj vojaškega sistema je pomembno, kar je o skupini poudaril Stogdill (1950; po Zvonarevič, 1985), in sicer, da gre pri tem za vprašanje prisotnosti vodje. Kadar imamo skupino s stalno prisotnim vodjo in definirane razlike v odgovornosti pri doseganju ciljev - oboje pa je v vojaškem okolju nepogrešljivo - skupino obravnavamo kot organizacijo. Takšno razlikovanje temelji na neenakomerni porazdelitvi socialne moči med posamezniki znotraj skupine oziroma organizacije.

\subsection{Interakcija znotraj skupine}

Če je socialna moč ločnica med skupino in organizacijo, nas zanimajo tudi pogoji, ki ustvarjajo socialno moč znotraj organizacije. Predvsem je to proces interakcije, ki se nanaša na vzajemno delovanje posameznikov znotraj skupine. Interakcija poteka tako v primeru, ko je posameznik v resnici obdan z drugimi člani skupine (prostorska bližina) ali pa se jih le zaveda (psihološka bližina), neredko pa sta sočasno prisotni obe. 
Med različnimi avtorji, ki so se posvečali vprašanju interakcije, sicer prihaja do nekaterih razlik pri določanju njenih posameznih mehanizmov, splošno sprejemljivi pa obsegajo elemente (glej npr. Zvonarevič, 1985):

a) posnemanje (imitacija) - predpostavlja se obstoj modela, ki služi kot vzor, in posnemovalcev, ki lahko zavedno (hote) ali nezavedno (nehote, samodejno) posnemajo vedenje modela. Posnemanje velja za najmanj naporen način učenja, v ozadju deluje težnja po konformizmu. Iz prakse so v vojaški organizaciji znani primeri, da podrejeni posnema nadrejenega v vedenju, govoru, telesni drži ipd.;

b) sugestija - podobna posnemanju, le da pri sugestiji model izvaja pritisk na sprejemnika (posnemovalca), od njegove dovzetnosti pa je odvisno, kako bo od modela prevzel zamisel, ki včasih tudi ni zadovoljivo argumentirana;

c) identifikacija se pojavlja, ko model v očeh posnemovalca uživa ugled oziroma avtoriteto. Z identifikacijo posnemovalec na videz povečuje tudi svojo pomembnost. Identifikacija z drugimi člani oziroma skupino in njenimi cilji se lahko pojavi tudi, če posameznik postane član skupine mimo svoje volje ali celo v nasprotju z njo (naborniki v sistemu obveznega služenja vojaškega roka, mobiliziranci itn.);

d) simpatija in antipatija - dva pola istega mehanizma. Gre za čustveno kategorijo, ki se prav zaradi tega lahko izrazi brez potrebnih razumskih omejitev, kar ima lahko močan vpliv na posameznika ali na vso socialno interakcijo v skupini;

e) socialni pritisk - gre za mehanizem, ko se v skupini vzpostavi vzdušje, ki članom skupine vzbuja občutek nevarnosti, če ne spoštujejo predpisanih pravil. Socialni pritisk skupina izvaja s sredstvi prepričevanja (prošnja, nasvet, priporočilo) ali sredstvi prisile (nagrada, obljuba, grožnja, kazen). Socialni pritisk vsekakor srečamo tudi v skupinah v vojaškem okolju, saj je lahko za skupino oziroma njene pripadnike zelo nevarno, če v kritičnih trenutkih pri doseganju skupnega cilja ne sodelujejo vsi člani. Žal se lahko pojavijo tudi negativni vidiki, ko zaradi socialnega pritiska skupine tudi tisti posamezniki, ki sicer tega ne bi storili, začnejo kazati različne oblike vedenja, ki niso v skladu z vojaškim pravom (npr. kruto ravnanje z vojnimi ujetniki in civilisti itn.). Kot ena ostrejših kazni v vojaških skupinah je znan bojkot, saj lahko posameznika, proti kateremu je usmerjen, razmeroma močno ogroža. Vojaške skupine oziroma enote se namreč neredko znajdejo v položajih, v katerih je medsebojna pomoč življenjsko pomembna;

f) inhibicija in facilitacija - gre za pojav, ko se zaradi prisotnosti drugih članov skupine aktivnost posameznika poslabša (zavre) ali izboljša (pospeši), pri čemer sploh ni nujno, da so preostali člani fizično prisotni. Mehanizem lahko deluje tudi, ko je posameznik v popolni fizični izolaciji, vendar pa kljub temu čuti psihično povezanost $\mathrm{z}$ drugimi člani in pripadnost skupini. Ta mehanizem $\mathrm{v}$ vojaškem okolju na primer pride do izraza, ko se vojaški ujetnik kljub ostremu 
zasliševanju ne zlomi, ampak mu občutek pripadnosti pomaga, da vzdrži tudi v položaju, ki ogroža njegovo življenje.

\subsection{Velikost in trajanje skupine}

Ob vprašanju prisotnosti drugih članov skupine in njihovem vplivu na vedenje posameznika je zelo pomembna tudi velikost skupine. Čim večja je skupina, tem močnejši je njen vpliv. Socialna psihologija govori o majhnih in velikih skupinah, kar ustrezaprevedeno v vojaško terminologijo - majhnim in velikim enotam v vojaški organizaciji. V razmerah vojaških spopadov je odločitev o tem, kako velika bo skupina, ki se angažira za izvršitev neke naloge, pač pogojena z objektivnim dejstvom - nasprotnikovo močjo. Še vedno pa velja Southova (1927; po Zvonerivič, 1985) ugotovitev, da so manjše skupine uspešnejše pri reševanju konkretnih vprašanj, večje pa pri spoprijemanju z abstraktnimi. South (prav tam) razlaga, da ima za konkretno vprašanje ali težavo vsak član že pripravljeno strategijo rešitve, majhno število članov pa ob tem pomeni krajši čas usklajevanja. Obratno pa je pri abstraktnih težavah ali vprašanjih uspešnejša velika skupina, saj je po zakonu verjetnosti večja možnost, da bo med večjim številom pripadnikov nekdo hitro našel ustrezno rešitev.

Velikost skupine pomembno vpliva na vodenje. Bales (1953; po Zvonarevič, 1985) je ugotovil, da se v skupinah, ki štejejo do pet pripadnikov, vodja sporazumeva $\mathrm{z}$ njimi kot s posamezniki, v večjih pa se nanje obrača kot na skupino.

Hemphill (1950; po Zvonarevič, 1985) pa je odkril, da so v skupinah, ki so štele največ trideset ljudi - v vojski je to velikost voda - zahteve do vodje manjše kot $\mathrm{v}$ večjih skupinah.

Skupine seveda lahko delujejo različno dolgo, zato moramo upoštevati tudi ta vidik. Delovaje nekaterih je kratkotrajno, kar pomeni, da delujejo le, dokler ni dosežen kratkoročni cilj, nato pa se ukinejo. $Z$ vojaškega vidika pa so bolj zanimive skupine, ki delujejo več časa, mednje spadajo standardne vojaške enote. Njihov cilj - zagotavljanje varnosti - je dolgoročen, skorajda trajen, zato so tudi same dolgotrajne. V mnogih vojskah imajo enote, ki so bistveno starejše od njihovih članov. Zanje velja, da preživijo številne generacije pripadnikov, ki se v njih zvrstijo. Skladno s tem se razvije tradicija, ki še dodatno utrjuje stabilnost skupine, ta pa je po mnenju mnogih avtorjev v pozitivni povezavi z njeno trajnostjo. Treba pa je upoštevati tudi, da se članstvo v teh skupinah pogosto menja, kar praviloma negativno vpliva na stabilnost.

V civilnem okolju najdemo podobnost v navijaških skupinah, v katerih se pri podpori nekemu športnemu klubu zvrsti več generacij članov.

\subsection{Socialna struktura}

Skupina ima svojo psihosocialno strukturo, tako horizontalno kot vertikalno. To pomeni, da se v vertikalni strukturi izraža hierarhija posameznih vlog in statusov, horizontalna struktura pa obsega posamezne podskupine, ki imajo enak status. 
V vojaških enotah je vertikalna struktura še posebno izražena in jasno formalizirana. $\mathrm{Na}$ vertikalno strukturo se veže pojav socialne stratifikacije, kar je vzrok nastanka podskupin, ki nimajo enakega socialnega statusa. Razlike izvirajo iz vloge, ki jo ima posameznik (podskupina) znotraj skupine. Višje ko je hierarhično mesto (vloga), ki ga posameznik (podskupina) zaseda, večjo možnosti vplivanja na aktivnosti in na preostale člane ima. Razlike med vlogami same po sebi niso vprašljive, saj so nujne za normalen razvoj skupnosti.

V zvezi s strukturo moramo osvetliti dva pomembna pojma, in sicer socialno distanco in socialno mobilnost. Socialna distanca je razlika v statusu med dvema posameznikoma ali socialnima podskupinama in kot takšna izvor morebitnih konfliktov, izvira pa iz različnih vlog in s tem povezane neenakomerne porazdelitve socialne moči. Lahko je vzrok konfrontacij med hierarhično višjimi, ki skušajo svoj privilegirani status obdržati, in tistimi, ki so na hierarhični lestvici nižje in bi radi položaj spremenili ali vsaj zmanjšali distanco.

Kot je bilo že rečeno, so v vojaških enotah ravno zaradi formaliziranosti vertikalne strukture vsi obravnavani pojmi še toliko bolj izraziti. Za vojsko je značilen sistem činov, ki so zunanji znak položaja posameznika v hierarhiji in s tem povezanega vpliva, ki ga ima ta na aktivnosti v skupini in na druge člane. Prav tako je v vojaškem okolju zaradi te formaliziranosti dobro opazna tudi socialna mobilnost, to je možnost spremembe socialnega statusa znotraj skupine. Obstaja institucionaliziran sistem napredovanja, po katerem posameznik ob izpolnjevanju vnaprej določenih pogojev napreduje po hierarhični lestvici, s čimer poleg materialnih ugodnosti pridobiva tudi na socialnem statusu. Socialna mobilnost in distanca sta tudi v medsebojni povezavi, manjša ko je socialna distanca, manjša je tudi težnja po socialni mobilnosti.

$\mathrm{Na}$ socialno strukturo se navezujeta še pojma formalne in neformalne skupine. $\mathrm{V}$ formalni skupini, v primerjavi z neformalno, so vloge in nanje vezana pričakovanja eksplicitno definirani. $Z$ vidika razvoja skupine se pogosto dogaja, da se najprej oblikuje neformalna skupina, ko pa struktura postane trajnejša in stabilnejša, se pojavi težnja $v$ smeri formalizacije. $Z$ vidika socialne dinamike je pomembno izpostaviti, da v okviru neke širše skupine, na primer tudi vojaške enote, lahko sočasno delujejo formalne in neformalne skupine, ki nastanejo kot rezultat različnih socialnih interakcij. Načeloma ta pojav sam po sebi ni vprašljiv, težave pa je pričakovati, če si neformalne skupine poskušajo prisvojiti vlogo formalnih, pri čemer bi prišlo do redistribucije socialne moči.

\subsection{Socialna moč}

Socialna moč je izraz, ki ga pogosto uporabljamo, tako v vsakdanjem pogovornem jeziku kot v strokovni terminologiji. Različne definicije, ki ga poskušajo strokovno opredeliti, se osredotočajo na različne vidike. Tako Lasswel in Kaplan (1950; po Zvonarevič, 1985) socialno moč vidita v sodelovanju pri odločanju, Schulze (1956; po Zvonarevič, 1985) pa meni, da je socialna moč potencial oziroma zmožnost 
člana skupine vplivati na preostale posameznike znotraj skupine. Drugi avtorji (Weber, 1946, Tannenbaum, 1968, Haer, 1963; po Zvonarevič, 1985) poskušajo razlagati socialno moč z uvajanjem pojmov, kot so volja, nadzor, akcija, determiniranje. Zvonarevič (1985) predlaga definicijo: »Socialna moč je sposobnost posameznikov, skupin ali organizacij (centri socialne moči), da vplivajo na aktivnosti in vedenje drugih posameznikov, skupin ali organizacij.« Čeprav je definicija na videz zelo preprosta, skriva $\mathrm{v}$ sebi pomembne elemente za raziskovanje socialne moči.

a) Centri socialne moči

Mednje spadajo posamezniki, skupine in organizacije, ki imajo poseben vpliv in jih na podlagi različnih meril delimo na:

- formalne in neformalne centre, pri čemer je za formalne značilno, da delujejo skladno z normativnimi pravnimi akti (ustava, zakon, statut, pravilnik, direktiva, ukaz itn.), medtem ko neformalni delujejo mimo takšnih normativov ali celo $\mathrm{v}$ nasprotju $\mathrm{z}$ njimi. $\mathrm{Z}$ vidika legalnosti so torej formalni centri moči vedno legalni, za neformalne pa to ne velja, zato so aktivnosti neformalnih skupin pogosto prikrite širši javnosti. Ni si težko predstavljati, da v vojaškem okolju dejavnosti neformalnih centrov moči privedejo do večjih ali manjših motenj pri doseganju cilja;

- individualni in kolektivni centri, pri katerih je merilo zelo jasno, ali gre za eno osebo (predsednik, premier, direktor, poveljnik itn.) ali več posameznikov (predsedstvo, komisija, odbor, senat itn.). Med individualnimi in kolektivnimi centri obstajajo pomembne razlike, predvsem v vodenju in odgovornosti, kar je tudi razlog, da vojska temelji na individualnih;

- nominalni in realni centri - nominalni naj bi navidezno imeli moč, realni pa je v resnici imajo. $\mathrm{V}$ vojaških enotah je za normalno delovanje nujno, da so nominalni centri v resnici tudi realni. Nasprotno bi namreč pomenilo, da enote ne vodi njen poveljnik, temveč nek neformalni in obenem realni vir moči, kar pa je v vojaškem okolju nesprejemljivo;

- notranji in zunanji centri - kot je mogoče sklepati že iz poimenovanja, imamo opraviti z jedri, ki delujejo znotraj oziroma zunaj skupine, na katero vplivajo. Tudi v tem primeru velja, da je za vojaške enote sprejemljiv edino obstoj notranjih virov moči. V nasprotnem, če se namreč v vodenje enote poskušajo vmešavati zunanji neformalni dejavniki, ki pa imajo realno moč, upravičeno pričakujemo motnje v normalnem delovanju. Takšnim poskusom so lahko zaradi svojega bolj ali manj naključnega oblikovanja izpostavljene začasne enote, navadno namenjene izvršitvi ene same, točno določene (tudi časovno) naloge. Primer tega so kontingenti v mirovnih operacijah v tujini, kjer se pripadniki na eni strani srečujejo s formalnim, realnim in notranjim centrom socialne moči, ki ga predstavlja poveljniška linija kontingenta, obenem pa ne morejo prezreti zunanjih, neformalnih, pa vendar realnih centrov, delujočih v okolju, od koder prihajajo in kamor se navadno vračajo, če bi se ti v resnici poskušali uveljavljati. 
b) Distribucija socialne moči

Distribucija socialne moči je izjemno pomemben dejavnik, saj ne vpliva le na medsebojne odnose med posameznimi centri, temveč pogojuje celotno socialno klimo v skupini (enoti), v kateri poteka. Lahko je monocentrična, kar pomeni, da je vsa moč v rokah enega centra, če pa jih je več, govorimo o policentrični distribuciji. Če imamo opraviti s policentrično distribucijo moči, se srečamo s pojmom hierarhije centrov moči, ki točno določa, kdo je komu nadrejen ali podrejen. S tega vidika izhaja, da se v vojaškem okolju srečujemo z monocentrično in tudi s policentrično distribucijo socialne moči, odvisno pač, iz katerega zornega kota gledamo. Na ravni temeljne vojaške enote je sprejemljiva le monocentrična distribucija, saj enote ne more voditi vsakdo po malem. Če pa gledamo na vojsko kot celotno institucijo, se nedvomno srečujemo s policentrično distribucijo socialne moči s sočasnim obstojem stroge hierarhije. Ta ne dopušča dvoma, kateri center je kateremu nadrejen, obstaja pa glavni, v katerem se vsi vzvodi moči združujejo.

c) Vpliv

Intenzivnost vpliva niha med dvema skrajnostma: ničelnim vplivom (kadar ga sploh ni zaznati) in maksimalnim (ko ima center možnost odločujočega poseganja). Vpliv je lahko neposreden, usmerjen neposredno na akcijo, ali pa posreden, če poteka prek vmesnega člena (ali poveljujoči neposredno ukazuje ali si pri tem pomaga s poveljujočimi na nižjih ravneh). Različen je tudi njegov obseg, saj ima center moči vpliv na različno število posameznikov ali skupin in tudi na različno število akcij, ki v skupini potekajo (v vojaškem okolju je obseg vpliva določen s hierarhično stopnjo, na kateri je center). Center, ki ima možnost vplivanja, lahko svoj potencial uresniči, v tem primeru govorimo o aktualnosti vpliva, ali pa tudi ne. Odvisno od tega, ali gre za individualni ali skupinski center moči, se srečujemo z individualnim ali skupinskim vplivom (v vojski skupinski vpliv redkeje najdemo, npr. odločitve, ki jih sprejemajo različne komisije, veliko pogosteje se srečujemo z individualnim vplivom).

Vplivi se med seboj, poleg drugega, ločujejo po trajnosti. Trajen vpliv imajo tisti centri moči, ki so tudi sami trajni, lahko trajajo tudi dlje od življenja posameznika. Obratno pa govorimo o kratkotrajnem vplivanju, kadar centri moči svoj potencial uporabljajo le občasno.

Legalnost vpliva se povezuje $\mathrm{z}$ delitvijo centrov socialne moči na formalne in neformalne. Formalni centri svoj vpliv uresničujejo legalno, vpliv neformalnih centrov pa je lahko ilegalen, pollegalen ali celo nelegalen (npr. klientelizem, nepotizem itn.) in kot tak škodljiv, pa naj gre za skupine v civilnem okolju ali vojaške enote.

č) Akcija oziroma aktivnost

Akcije se med seboj razlikujejo glede na pomembnost, vsebino, načrtovanost in individualnost.

Pomembnost akcije je njeno najmočnejše orodje, saj je z njo določena količina socialnega vpliva, ki se uveljavi. Vsaka akcija ima svojo vsebino, določeno s 
področjem, na katerem poteka. Ker lahko registriramo izjemno veliko število področij, bi temu primerno lahko govorili tudi o zelo velikem številu vsebin. V praksi pa se navadno omenjajo ekonomske, politične, kulturne in zdravstvene vsebine, z vojaškega vidika so za nas zanimive vsebine, ki bi jih opredelili kot varnostne.

Naslednja značilnost akcije je njena načrtovanost ali nenačrtovanost. Večina akcij je načrtovanih, nekatere pa so spontane. Delitev na načrtovane in spontane je smiselna, ker je vpliv centrov socialne moči pri načrtovanih veliko bolj izražen kot pri nenačrtovanih. Ne nazadnje, akcije delimo na individualne, pri katerih deluje le en pripadnik skupine, in na kolektivne, pri katerih sodeluje skupina.

e) Količina socialne moči

Količina socialne moči je resnični pokazatelj pomembnosti centra socialne moči, odvisna pa je od dveh elementov: pomembnosti akcije, na katero ta center vpliva, in intenzivnosti vpliva. Iz tega sklepamo, da ima veliko socialno moč posameznik ali skupina (center socialne moči), ki intenzivno vpliva na pomembne akcije. Obratno velja, da center z manjšo socialno močjo vpliva na manj pomembne akcije, pa še to malo.

Kot je bilo že rečeno, se v vojaškem okolju srečujemo s policentričnim sistemom distribucije socialne moči, pri čemer so posamezni centri med seboj v jasnem hierarhičnem razmerju. Za vse velja, da imajo načeloma najbolj intenziven vpliv, razlika med njimi pa je, da vplivajo na različno pomembne akcije, pač skladno s svojim položajem v hierarhiji.

\section{SLOVENSKA VOJSKA Z VIDIKA TEMELJNIH POJMOV SOCIALNE PSIHOLOGIJE}

Do zdaj smo skušali osvetliti temeljne pojme, ki jih uporablja socialna psihologija. V naslednjem poglavju pa želimo s temi pojmi razložiti nekatere vidike delovanja vojske in vojaške skupine.

\subsection{Metodologija}

Za podlago služijo izkušnje in spoznanja, ki sledijo iz dela psihologa v Slovenski vojski, saj sta avtorja kot enotovna psihologa spremljala več enot, tako doma kot na mednarodnih misijah, predvsem načrtno z analizo psihosocialne klime.

Analiza psihosocialne klime v enotah Slovenske vojske redno poteka, doma enkrat do dvakrat na leto, odvisno od nalog in potreb, za enote na misijah pa vsaj dvakrat v pol leta. Praviloma je v dveh delih, podlaga zanjo pa so enotni vprašalniki, namenjeni notranji uporabi. Z vprašalniki poskušamo izmeriti te sklope: horizontalna kohezivnost (zaupanje in razumevanje med pripadniki na isti ravni v enoti), vertikalna kohezivnost (zaupanje in razumevanje med poveljujočimi in podrejenimi), kakovost prenosa informacij (jasnost in pravočasnost informacij za opravljanje naloge) in način zagotavljanja standardov (način uporabe nagrad in kazni ter zadovoljstvo z 
uveljavljenimi standardi). Na vprašalnike navadno odgovarjajo vsi pripadniki enote, na podlagi rezultatov vprašalnika pa se opravijo še pogovori z njimi (ločeno vojaki in poveljujoči).

Kot dodaten vir informacij služijo tudi druge oblike spremljanja enot in njihovih pripadnikov. To so tako formalni in neformalni pogovori s pripadniki, sodelovanje na poveljniških sestankih in terenskih usposabljanjih ter udeležba na mednarodnih misijah.

Ko se lotimo z vidika temeljnih pojmov socialne psihologije pogledati nekatere vidike delovanja vojske in vojaške skupine v Slovenski vojski, je treba razlikovati med dvema vidikoma: vojsko kot institucijo in vojaško enoto.

\subsection{Vojska kot institucija}

Glede na to, da je vojska skupina s stalno prisotnim vodjo in jasno definiranimi razlikami v odgovornosti pri doseganju ciljev, smo upravičeni sklepati, da je skupina prerasla v organizacijo. Znotraj te (vojaške) organizacije opažamo neenakomerno porazdelitev socialne moči med posamezniki ali podskupinami (centri socialne moči). Socialna moč se razširja policentrično, pri čemer je očitna stroga hierarhija med posameznimi centri. Hierarhija je obenem izvir vpliva centrov - višje ko so na hierarhični lestvici, večji je njihov vpliv. Tako je znotraj vojaške organizacije jasno, da je poveljnik čete nad poveljnikom voda in da je poveljnik brigade tisti, katerega moč velja za vso brigado, medtem ko moč poveljnika polka velja le za del te brigade.

Slovenska vojska je razmeroma velika in trajna organizacija, saj je namenjena doseganju trajnega cilja (varnost države pred zunanjim sovražnikom in naravnimi nesrečami). Centri socialne moči so praviloma formalni, individualni (poveljniška odgovornost) in notranji. Uniformiranost in jasne oznake služijo temu, da lahko kdor koli v organizaciji prepozna vlogo in socialno moč drugega pripadnika, tudi če je ta zanj popolnoma neznan. Hkrati pa v Slovenski vojski velja načelo enostarešinstva, kar pomeni, poveljuje lahko le eden. Hkrati s hierarhično ureditvijo to pomeni, da je na vrhu vsake piramide (voda, brigade vojske) le en poveljujoči. Nominalni centri morajo biti obenem tudi realni centri socialne moči.

Kot za vse skupine tudi za vojsko velja, da je znotraj nje nenehno prisotna interakcija med posamezniki ali podskupinami. Interakcija poteka tako v okoliščinah prostorske (posameznik je obdan z drugimi pripadniki) kot psihološke bližine (drugi pripadniki fizično niso prisotni).

Od interakcijskih mehanizmov v vojski srečujemo praktično vse tiste, ki jih socialna psihologija pozna tudi sicer: posnemanje, sugestijo, identifikacijo, socialni pritisk ter inhibicijo oziroma facilitacijo. 
Posnemanje je prisotno v vseh vidikih, je pa praviloma izrazitejše v mlajših enotah, pri pripadnikih, ki vstopajo v sistem. Pravilna izbira modela in uspešno sledenje sta podlaga za dobro vključevanje $\mathrm{v}$ enoto.

Identifikacija je značilnejša za enote na višji stopnji delovanja. Pripadniki ponotranjijo standarde in norme skupine. V vlogi prototipa in hkrati osebe avtoritete pa je poveljujoči. Nevarno za enoto lahko postane, če kot objekt identifikacije služi pripadnik, ki nasprotuje formalni strukturi vodenja.

Socialni pritisk se v vojaških enotah pojavlja v različnih oblikah. Prisotne so formalne oblike, na primer predpisane sankcije za odklonsko vedenje. V nekaterih enotah se pojavlja socialni pritisk kot del bolj ali manj neformalnih iniciacijskih procesov, ki spremljajo vključevanje novega pripadnika v enoto. Primeri so lahko obvezna uporaba posebej določenih tobačnih izdelkov, ki služijo kot znak pripadnosti enoti, rizične aktivnosti, s katerimi se dokazuje lojalnost enoti, in doseganje nadstandardov usposobljenosti. Iz primerov je razvidno, da so lahko posledice socialnega pritiska v vojaški enoti tako pozitivne kot negativne oziroma škodljive. Pri usmerjanju socialnega pritiska in njegovem obvladovanju ima veliko vlogo poveljniška struktura.

Socialna struktura v vojski je jasno določena, kar še posebej velja za vertikalno strukturo, ki je formalizirana tudi s sistemom činov, temelji pa na hierarhični lestvici. $\mathrm{S}$ tem se pojavljata socialna distanca in $\mathrm{z}$ njo povezana socialna mobilnost, ki poteka znotraj institucionaliziranega sistema napredovanja. Kljub temu pa se v vojaških sistemih vzpostavlja tudi neformalna socialna struktura, ki lahko podpira formalno ali pa ji nasprotuje. Tako ima lahko navaden vojak, ki sicer nima formalne moči, zaradi svojih izkušenj in znanja v enoti velik vpliv. Dobri poveljujoči temu vplivu praviloma ne nasprotujejo, temveč ga v svojem delovanju uporabijo kot podporo. V nekaterih primerih pa se nasprotovanje med formalno in neformalno strukturo izrazi kot upor podrejenih poveljujočim. Če se to zgodi, je lahko delovanje vojaške enote zelo okrnjeno. Na bojišču so lahko posledica tega žrtve, do katerih sicer ne bi prišlo.

\subsection{Vojaška enota}

Če želimo osvetliti skupinske dinamične mehanizme v vojaških enotah v ožjem pomenu besede, se pojavi vprašanje, kaj sploh je osnovna enota v Slovenski vojski. Publikacija Navodilo - lahka pehotna (motorizirana) četa jasno navaja, da je četa osnovni in najpomembnejši del organizacije in temelji na podlagi sprejete kadrovske in materialne formacije. Zato nam bo ravno četa služila kot referenčni okvir za osvetlitev skupinskih dinamičnih mehanizmov v vojaški enoti. Četo lahko uvrstimo med velike skupine, saj ima na primer pehotna četa okoli 120 pripadnikov. Tudi druge čete imajo praviloma več kot 60 pripadnikov. So pa sestavljene iz manjših enot, vodov in oddelkov, ki jih lahko uvrščamo že v sklop majhnih skupin. Vod, kot največja med njimi, šteje približno 30 pripadnikov.

V četi obstaja policentrični sistem distribucije socialne moči. Poveljujoči na četni ravni je hierarhično najvišji in ima kot posameznik odločilen vpliv na podrejenega 
poveljnika voda, ta pa na poveljnika oddelka. Vsi ti centri socialne moči so formalni in notranji. Prav tako so vsi nominalni ter obenem realni. Sočasno delovanje neformalnih centrov ni nujno kontraproduktivno, če njihov vpliv ni v nasprotju z aktivnostjo formalnega centra.

Prisotni so enaki mehanizmi socialne interakcije kot v vojski kot celoti, tudi socialna distanca ter težnja po socialni mobilnosti. Pojavlja se fluktuacija članstva, del tega je posledica izstopa nekaterih pripadnikov (upokojitev, menjava zaposlitve) in zaposlovanja novih. Pripadniki krožijo tudi po različnih dolžnostih znotraj Slovenske vojske. Kroženje po sistemu jim omogoča nabiranje izkušenj in znanja, ki bi bilo sicer zanje težje dosegljivo. Del fluktuacije je tako posledica tega, da pripadniki z novim znanjem in novimi kompetencami napredujejo tudi vertikalno. Fluktuacija pa ima lahko tudi negativen vpliv, če je preveč intenzivna. Neprestana menjava članstva pomeni, da se lahko zaupanje v preostale pripadnike enote gradi le na formalni podlagi. Predvsem za manjše enote (vod, tudi četa) pa se kaže, da je za dobro delovanje enote nujno zaupanje, pridobljeno na osebni izkušnji (skupno delo na terenu, uspešno opravljene naloge itn.) Prevelika fluktuacija onemogoča, da bi znotraj enote potekali procesi, v katerih enota zori in postaja učinkovitejša.

Fluktuacija ima lahko v vojaškem sistemu tudi higiensko vlogo. S pravilnim pretokom pripadnikov se manjša verjetnost, da bi neformalne vloge znotraj enote in s tem neformalni centri moči pridobili večjo moč kot formalni.

V Slovenski vojski se zaradi sorazmerne majhnosti sistema in zastavljenosti kariernih poti dogaja, da je pretočnost poveljniškega kadra večja kot pretočnost vojakov. Občasno se zaradi tega zgodi, da morajo poveljujoči, predvsem v manjših enotah, pokazati več spretnosti pri sodelovanju z nosilci neformalne moči, saj imajo ti, vsaj na začetku, večji pregled nad stanjem in življenjem enote kot poveljujoči.

Glede na to, da so posamezniki v osnovnih vojaških enotah praviloma obdani z drugimi člani, upravičeno govorimo o pojmu prostorske bližine, psihološka bližina pa je temelj občutka pripadnosti enoti. Pripadnost enoti je v resnici tisto, kar si želijo poveljujoči, predvsem tisti, ki se zavedajo, da moč enote ne temelji le na orožju in opremi, temveč predvsem na ljudeh. Izkušnje potrjujejo, da se psihološka bližina gradi s prostorsko bližino, pri čemer pojem prostorske bližine pri vojaški enoti širimo tudi na prostor skupnih izkušenj. Praviloma velja, da imajo enote, katerih pripadniki intenzivneje delijo izkušnjo »biti skupaj« v raznolikih situacijah, tudi intenzivnejši občutek psihološke bližine oziroma pripadnosti. Graditi občutek pripadnosti v različnih izkušnjah pa pomeni, da za to potrebujemo čas. Bolj ko je naloga zahtevna, več ko je pripadnikov enote, ki morajo biti usklajeni, več časa potrebujemo.

Sklep V članku smo poskusili slediti dvema ciljema. Prvi je narediti pregled temeljnih pojmov socialne psihologije, drugi pa s temi pojmi razložiti vojaško organizacijo z vidika izkušenj, pridobljenih v Slovenski vojski. 
Tem ciljem smo uspeli slediti le v omejenem obsegu. Tako na primer ostaja skoraj nedotaknjena tema dinamike majhnih skupin in posebnosti te dinamike v vojaških enotah. Nismo se dotaknili delitve na taktično, organizacijsko in strateško raven znotraj vojaške hierarhije in povezave te delitve s socialno močjo. Nedotaknjena je tema interakcije vojaške organizacije z okoljem, na primer, kako lahko stališča širše javnosti vplivajo na delovanje kontingenta $\mathrm{v}$ mednarodni operaciji.

Prav tako smo le na splošno predstavili spoznanja, ki sledijo iz dela v Slovenski vojski.

Kljub temu upamo, da je članek uspel v tem, da je predstavil nekatere temeljne pojme socialne psihologije in uspešno pokazal na dodano vrednost, ki jo pridobimo, če s teh vidikov pogledamo na vojaško organizacijo.

1. Banaji, M. R., Heiphetz, L., 2010. Attitudes. V S. T. Fiske, D. T. Gilbert, G. Lindzey, ur. Handbook of Social Psychology, Fifth edition, vol.1. New Jersy: Wiley, 2010, str. 353393.

2. Bruner, J. S., 2005. On Perceptual Readiness. VD. L. Hamilton, ur. Social Cognition. New York: Psychology Press. 2005, str. 108-114.

3. Correl, J., Park, B., Judd, C. M., Wittenbrink, B., 2005. The Police Officer 's Dilemma: Using Ethnicity to Disambiguate Potentially threatening Individuals. V D. L. Hamilton, ur. Social Cognition. New York: Psychology Press. 2005, str. 451-469.

4. Dijksterhuis, A., 2010. Automaticity and The Unconcious. V S. T. Fiske, D. T. Gilbert, G. Lindzey, ur. Handbook of Social Psychology, Fifth edition, vol.1. New Jersy: Wiley, 2010, str. 228-267.

5. Dunning, D., Sherman, D. A., 2005. Stereotypes and Tacit Inference. V D. L. Hamilton, ur. Social Cognition. New York: Psychology Press. 2005, str. 48-62.

6. Hamilton, D. L., 2005. Social Cognition. New York: Psychology Press.

7. Heider, F., 2005. The Naive Analysis of Action. V D. L. Hamilton, ur. Social Cognition. New York: Psychology Press. 2005, str. 288-298.

8. Levine, J. M., Moreland, R. L., 2006. Small Groups: An Owerview. V J. M. Levine, R. L. Moreland ur. Small Groups. New York: Psychology Press, 2006, str. 1-32.

9. Lieberman, M. D., 2010. Social cognitive neuroscience. V S. T. Fiske, D. T. Gilbert, G. Lindzey, ur. Handbook of Social Psychology, Fifth edition, vol.1. New Jersy: Wiley, 2010, str. 143-193.

10. Malone, D. M., 2003. Small Unit Leadership: A Commonsense Approach. New York: Balantine Books.

11. Pashler, H. E., 1999. The Psychology of attention. Massachusetts: MIT.

12. Styles, E., 2006. The Psychology of Attention, 2nd edition. New York: Psychology Press.

13. Ule, M., 2009. Socialna psihologija. Analitični pristop k življenju v družbi. Ljubljana: Založba FDV.

14. White, J. D., Sherman, D. A., 2005. Consequences of Shemata for Attention, Impressions, and Recall in Complex Social Interactions. V D. L. Hamilton, ur. Social Cognition. New York: Psychology Press. 2005, str. 36-47.

15. Zvonarevič, M., 1985. Socialna psihologija. Zagreb: Školska knjiga. 


\section{PSIHOLOŠKO DELOVANJE - VOJAŠKO DELOVANJE ALI UPORABNA SOCIALNA PSIHOLOGIJA?}

\section{PSYCHOLOGICAL OPERATIONS - MILITARY OPERATIONS OR APPLICABLE SOCIAL PSYCHOLOGY?}

Povzetek Psihološko delovanje je pogosto razumljeno kot povsem vojaška vsebina, ki z znanostjo in stroko nima prave zveze. Vendar so v ozadju vojaških aktivnosti individualni in skupinski psihološki procesi, razumevanje katerih omogoča bistveno večjo učinkovitost delovanja. Gre za procese, na katerih temeljijo tudi aktivnosti, s katerimi se srečujemo vsak dan, ne da bi o tem kadar koli razmišljali - marketing, informativni programi, reklamiranje, medijske kampanje.

Članek osvetljuje področje psihološkega delovanja z različnih vidikov: z vidika vojaških ved, socialne psihologije ter psihologije tržnega komuniciranja. Pri tem poskuša definirati tako posebnosti, ki so značilne za vsakega izmed navedenih področij, kot tudi določiti skupno polje delovanja oziroma nekakšen presek množic. Poseben segment je namenjen študiji primera zgibanke, uporabljene na Kosovu leta 2007, ki je kot »vojaška aktivnost« analizirana $\mathrm{z}$ vidika socialne psihologije in psihologije (tržnega) komuniciranja.

Ključne

Psihološko delovanje, oborožene sile, socialna psihologija, komunikacija, mediji.

besede

Abstract Psychological operations are often seen as a purely military subject with no real relation to science and profession. However, the background of military activities includes individual and group psychological processes the understanding of which enables a much better operational performance. This involves the processes underlying the activities we encounter every day without ever even thinking about it marketing, information programmes, advertising, and media campaigns.

The article highlights the areas of psychological operations from various aspects: military science, social psychology and psychology of marketing communication. In this respect, it, both, attempts to define the features specific to each of those areas, as well as to establish a common field of activity or some kind of intersection of all sets. A special part of the article is devoted to a case study of a leaflet used in Kosovo in 
2007, a »military activity«, which is analysed from the perspective of social psychology and psychology of marketing communication.

Key words Psychological operations, armed forces, social psychology, communication, media.

Uvod Že Immanuel Kant je sanjal o trajnem miru na svetu (www.earlymoderntexts.com), vendar je videti, da namesto trajnega stanja miru zemljo pretresajo trajni spopadi in vojne narodov, ki drugim poskušajo vsiliti lastne vrednote ali zadovoljiti svoje politične in/ali ekonomske interese. Samo od druge svetovne vojne je na različnih koncih sveta potekalo več kot 200 vojaških operacij, ki jim ni videti konca (www.eruditionline. com). Nasprotno, odpirajo se nova in nova krizna žarišča in ko gre za »vojaško« tehnologijo in strategijo - posebno, če sem vštejemo iznajdljivost v ozadju terorističnih dejanj - človekova domišljija ne pozna meja. Od visoko razvite računalniške tehnologije do improviziranih sredstev uničevanja, sestavljenih iz povsem vsakdanjih izdelkov za domačo rabo, ki ležijo po podstrešjih in kleteh. Je torej imel Clausewitz prav, ko je zapisal, da je vojna »zgolj nadaljevanje politike z drugimi sredstvi«?

Ne glede na to, kako vidimo vzroke za nastanek vojne ali dejanja, ki delujejo kot sprožilci, ne moremo mimo dejstva, da ima vsaka vojna, spopad, vojaška operacija ali pa teroristično dejanje tudi svojo psihološko dimenzijo. Da za vsakim dejanjem stoji človek s svojimi močnimi in šibkimi točkami. Ter da vsako dejanje za seboj potegne množice, ki so tako ali drugače prizadete. In prav »množice« - kot skupek posameznikov in kot posebna entiteta - so tiste, na katere želimo neposredno ali posredno vplivati. Eno zmed orodij vplivanja na množice je tudi psihološko delovanje kot majhen, a pogosto pomemben in učinkovit segment vojšakega delovanja v miru in vojni.

\section{METODOLOŠKO HIPOTETIČNI OKVIR}

Članek temelji na teoretičnih metodah dela, ki vključujejo zbiranje podatkov iz primarnih dostopnih virov, sekundarnih virov ter podatkov, dostopnih prek svetovnega spleta. Povsem »vojaške aktivnosti« so osvetljene z vidika socialne psihologije v najširšem smislu ter psihologije tržnega komuniciranja. Za razumevanje povezave med strogo teoretičnim (strokovnim) in povsem praktičnim (vojaškim) delom so v članek vključene osnovne definicije psihološkega delovanja, značilnosti ter aktivnosti, ki jih vojska izvaja »v blatu in prahu«.

Del analize in razprave je namenjen (1) študiji primera zgibanke Slovenske vojske na Kosovu. Leta 2007 je v okviru bojne skupine Sokol na Kosovu delovalo približno 600 pripadnikov SV in civilnih oseb iz Slovenije. V tem času je bila zaradi krepitve dobrih odnosov izvedena kampanja, v okviru katere je bilo natisnjeno in razdeljeno večje število zgibank. Omenjeno aktivnost lahko opredelimo kot eno bolj prepoznavnih samostojnih aktivnosti psihološkega delovanja SV na območjih kriznih Žarišč. 
Drugi del (2) je namenjen premisleku o tem, v katero stroko psihološko delovanje pravzaprav spada. Gre za povsem vojaško strategijo in taktiko, za uporabno socialno psihologijo ali psihologijo tržnega komuniciranja?

\section{PSIHOLOŠKO DELOVANJE}

\section{"Na svetu obstajata dve sili; sila meča in sila uma. Toda na dolgi rok sila uma vselej premaga silo meča." \\ Napoleon}

\subsection{Definicija psihološkega delovanja}

Psihološko delovanje je kot komponenta informacijskega delovanja v Doktrini SV (Furlan, 2006, 67) opredeljeno kot »načrtovana psihološka dejavnost v miru in vojni, usmerjena v sovražne, lastne ali nevtralne ciljne skupine $\mathrm{z}$ namenom vplivanja na njihovo stališče in vedenje v podporo doseganju političnih ali vojaških ciljev.« Cilj psihološkega delovanja je slabljenje sovražnikove volje do bojevanja, krepitev podpore in lojalnosti lastnih in prijateljskih ciljnih skupin ter pridobivanje naklonjenosti tistih, ki so neodločeni ali nevtralni.

Ameriška doktrina informacijskega delovanja (US, Joint Chiefs of Staff, 2006, II-1) psihološko delovanje definira kot »načrtovano delovanje za prenos izbranih kredibilnih informacij tujim prejemnikom z namenom vplivanja na čustva, motive, razumevanje in končno tudi vedenje tujih vlad, organizacij, skupin ali posameznikov«. Namen psihološkega delovanja je ustvariti ali okrepiti stališča in vedenja tujih populacij, in sicer tako, da bodo ta naklonjena ciljem vira sporočila.

Ker gre za pomemben medij, velja omeniti tudi eno od opredelitev z medmrežja, ki meni, da gre v primeru psihološkega delovanja za »psihološke aktivnosti in psihološko vojskovanje, ki zaokrožuje tiste politične, vojaške, ekonomske in ideološke aktivnosti, ki so načrtovane in izvedene, da bi pri sovražnih, nasprotnih, nevtralnih ali prijateljskih skupinah oblikovale čustva, stališča in vedenje, ki bo naklonjeno doseganju nacionalne politike in ciljev« (www.eruditiononline.com).

Lahko bi dejali, da se v večini opredelitev psihološkega delovanja ponavljajo nekateri skupni osnovni elementi:

- psihološko delovanje razumejo kot poskus vplivanja na posameznike in skupine,

- navadno se nanašajo na stališča in osnovne elemente stališč - kognitivni, afektivni, vedenjski,

- usmerjeni so na (bolj ali manj skrbno) izbrane ciljne populacije,

- v ozadju delovanja so prisotni interesi oziroma cilji, v smeri katerih naj bi vplivanje delovalo.

Psihološko delovanje je v vojaškem okolju (posebej v zadnjih letih) navadno razumljeno kot eno izmed stebrov in ključnih zmogljivosti informacijskega delovanja, tj. 
»načina bojnega in nebojnega delovanja, ki se izvaja v miru in vojni v podporo političnim ali vojaškim ciljem, za vplivanje na osebe, ki sprejemajo odločitve« (Furlan, 2006, str. 52). Poleg psihološkega delovanja koncept informacijskega delovanja vključuje še elektronsko bojevanje, omrežno bojevanje, zavajanje in varnostno delovanje (Paul, 2008).

V literaturi, ki obravnava psihološko delovanje, je pogosto uporabljana različna terminologija, ki je odvisna od aktualnih smernic, v katerih je nastajala, od virov, na katerih temelji, in od izbire avtorja. V kontekstu vojaških operacij tako lahko srečamo izraze, kot so psihološke operacije (angl. Psychological Operations ali kot kratica PSYOPS), psihološko bojevanje, psihološko delovanje, propaganda itn.

Arnejčič (2008, str. 281) psihološko vojskovanje opredeljuje kot širši pojem, katerega namen je poskus vplivanja na javnost oziroma javno mnenje in ga definira kot »načrtovano in ciljno usmerjeno dejavnost v vojni in miru, ki uporablja spoznanja psihologije, da vpliva na vedenje nasprotnih množic in posameznikov«, medtem ko gre pri propagandi za predstavitev konkretnega dogodka na način, ki bi lahko vplival na druge posameznike.

Čeprav med posameznimi pojmi lahko opredelimo razlike, polemiziranje o ustreznosti uporabe enega ali drugega termina ter ugotavljanje, koliko se posamezni pojmi vsebinsko prekrivajo ali gre celo za sopomenke, za potrebe članka ni posebej bistveno. V članku pretežno uporabljen pojem »psihološko delovanje« se nanaša na veljavno Doktrino SV (Furlan, 2006).

\subsection{Namen in cilji psihološkega delovanja}

Logika psihološkega delovanja poskuša slediti nekaterim osnovnim predpostavkam:

1. Vsaka vojaška aktivnost ima tudi svojo psihološko dimenzijo in v tem kontekstu lahko na različne populacije vpliva zelo različno, torej mora biti aktivnost skrbno načrtovana, mogoče posledice pa pretehtane z različnih vidikov. Če na primer vstopamo v miren zaselek tako, da jasno razkazujemo svojo moč, z oklepljenimi vozili, rožljajočim orožjem, grobo in neuvidevno, to objektivno predstavlja negativno konotiran dražljaj - grožnjo in ustrahovanje. In vendar ga bodo različne skupine lahko različno razumele. Nasprotniki kot pritisk, ki mu velja popustiti, ali pa poziv k negativnemu odgovoru, neopredeljeni morebiti zgolj kot ustrahovanje, ki si ga niso zaslužili in jih bo potisnil v obrambno držo, ter podporniki kot dolgo pričakovano rešitev.

2. Na ljudi (posameznike in skupine), na njihova stališča in vedenje je mogoče vplivati. Pri tem moramo vzeti v zakup, da prepričevanje ljudi ni »sprint«, ampak »tek na dolge proge«, med katerim moramo skrbeti za ohranjanje kontinuitete, konsistentnosti in kredibilnosti. 
Ustrezno načrtovano, koordinirano in izvajano psihološko delovanje naj bi pozitivno vplivalo na stališča različnih ciljnih populacij, pri čemer pozitivno pomeni v smeri zastavljenih ciljev in bi torej moralo (1) slabiti voljo nasprotnih ali potencialno sovražnih skupin, (2) krepiti naklonjenost prijateljskih skupin ter (3) pridobivati podporo tistih, ki se niso opredelile.

Namen aktivnosti psihološkega delovanja ni le informiranje - slednje je v domeni odnosov z javnostmi in sorodnih zmogljivosti -, temveč prepričevanje in usmerjanje izbrane ciljne populacije k izbiri (za nas oziroma vir sporočila) ustrezne rešitve. Prisotnost enot, ki izvajajo aktivnosti psihološkega delovanja na terenu, hkrati omogoča (vsaj posredno) komunikacijo med poveljnikom in prebivalstvom, vpogled v psihološki učinek drugih aktivnosti ter informacije o tem, kako se različne populacije na območju delovanja odzivajo. Predvsem neposredna komunikacija, medsebojno spoznavanje, vzpostavljanje pogojev za skupne izkušnje ter posledično približevanje stališč so hkrati temelj za ustvarjanje zaupanja. S tega vidika aktivnosti psihološkega delovanja, po možnosti podprte z ustreznimi dejavnostmi civilno-vojaškega sodelovanja, lahko delujejo tudi kot način zagotavljanja varnosti in zaščite lastnih sil.

Nekateri avtorji psihološko vojskovanje in/ali delovanje povezujejo izključno z namenom zlomiti voljo do vojskovanja ter vzpostaviti okoliščine, ki bodo okrepile pojav bojnega oziroma operacijskega stresa pri nasprotniku. In čeprav bi to veljalo za ozko gledano pojmovanje vojskovanja ob predpostavki, da gre za simetrično vojskovanje v bolj tradicionalnem smislu (vojska proti vojski), s tem, ko se na območju delovanja znajdemo med lokalnim prebivalstvom, katerega odnos do nas je lahko zelo zapleten, in navzkrižnim ognjem najrazličnejših interesov nasprotnikov in zaveznikov, psihološko delovanje zagotovo ni omejeno le na ustrahovanje.

\subsection{Psihološko delovanje včeraj, danes, jutri ...}

Z vse večjim uveljavljanjem in izpostavljanjem nekinetičnega vojskovanja ter širitvijo medijev in telekomunikacij v vse kotičke našega življenja se zdi, da gre pri psihološkem (in širše - informacijskem) delovanju za uporabo razmeroma novih metod. In vendar temu ni tako. Psihološko delovanje je eno najstarejših orožij v človekovem arzenalu, ki se je na takšen ali drugačen način uporabljalo že od nekdaj. Tako so iz zgodovine poznani primeri (predvsem druga svetovna vojna, Koreja, Vietnam itn.) uporabe propagande za doseganje vojaških in političnih ciljev na načine, ki niso bistveno drugačni od sedanjih, ohranile pa so se tudi nekatere oblike diseminacije (npr. letaki, posterji itn.) (www.psywar.com). Podobno kot pri trženju in potrošništvu se je skozi čas spreminjala predvsem tehnologija, medtem ko procesi, na katerih psihološko delovanje temelji, ostajajo isti. Ključni preskoki so se dogajali z razvojem, uporabo in širitvijo elektronskih medijev (TV-programi, medmrežje, socialna omrežja, pametni mobilni telefoni idr.), ki prepričevanje in vplivanje na posameznika in množice ter njihovo informiranost postavljajo v povsem nov kontekst. Tudi zato, ker od z informacijami in dobrinami prenasičenih prebivalcev razvitega dela sveta zahtevajo razumevanje, da hkrati obstaja mesto z več stotisoč prebivalci, kjer je električna energija dostopna le nekaj ur na dan, in področja, kjer večina 
informacij še vedno kroži prek neposredne komunikacije. Okolja vojaških operacij, v katerih delujeta Nato in OZN, ter pod njihovim okriljem tudi SV, tako pogosto predstavljajo kaotično in nedoumljivo kombinacijo primitivne plemenske ureditve in Facebooka.

Tako kot tehnologija, se je spreminjala tudi terminologija. Če smo pred desetletji pred TV-dnevnikom spremljali EPP - ekonomsko propagandni program - nas zdaj (tudi med oddajami) motijo »reklame «. Nekatere celo za iste proizvode kot takrat, ko smo jim poljudno ravno tako rekli »reklame«. Beseda propaganda je s padcem zidov in režimov postajala vse bolj politično nekorektna, nekakšen simbol manipuliranja in vsiljevanja ideologije. V sodobnem vojaškem okolju je dolgo skoraj ni bilo mogoče zaslediti in ravno tako se z njo le redko srečujemo v novejši strokovni literaturi. Ali, kot je ob neki priložnosti izjavil polkovnik Jack Summe, nekdanji poveljnik ene pomembnejših ameriških enot za psihološko delovanje: »svoje delovanje imenujemo operacije in njihovo propaganda«, čeprav gre za enake mehanizme. Izraz propaganda se ponovno pojavlja v novejših različicah temeljnih dokumentov nekaterih vojsk (npr. FM 3-05.30; Psychological Operations).

Bolj kot sam koncept in vsebina se torej spreminjata forma in terminologija. Če je bilo prej govora o propagandi, ki ima negativno konotacijo, zdaj govorimo o psihološkem in/ali informacijskem delovanju. Če so bili prej primarni mediji posredovanja informacij živi ljudje in pozneje tisk, radio in kino, se zdaj večina informacij posreduje prek nevidnih signalov - računalnikov, mobilnih telefonov, satelitov itn. Tehnološkemu napredku se (tudi na teh področjih) tudi vojske ne morejo ogniti; še več, prenekatera tehnologija je svoj zagon dobila prav zaradi potreb vojsk.

\section{PSIHOLOGIJA KOT TEMELJ PSIHOLOŠKEGA DELOVANJA}

\section{"Osvojite njihova srca in duše in misel bo sledila ... $"{ }^{1}$}

www.psywarrior.com

Dobro načrtovano in pripravljeno psihološko delovanje, ki naj podpira poveljnikovo namero ter vpliva na ciljne populacije v želeni smeri, temelji na osnovnih spoznanjih psihološke stroke ter nekaterih družboslovnih ved (kulturne antropologije, sociologije ipd.). Tako je nujno poznavanje nekaterih psihičnih pojavov in procesov kot tudi družbene dinamike.

\subsection{Nekateri psihološki pojmi kot temelj izbire in oblikovanja sporočila}

\section{Potrebe in motivi}

Zadovoljevanje potreb je eno ključnih gonil človekovega delovanja. Zvonarević (1984) potrebo definira kot stanje organizma ali socialno situacijo, ki obstaja neodvisno od posameznika, ki je v stanju porušenega biološkega ali socialnega ravnovesja.

\footnotetext{
»Win their hearts, and their souls and minds will follow ..."
} 
Abraham Maslow navaja pet osnovnih motivov oziroma temeljnih potreb, ki so pomembno gonilo človekovega vedenja (Musek, 1988, 1993; Lamovec, 1988), prek njih pa lahko razmeroma preprosto razložimo prenekatero dejanje. Po svoji pomembnosti se motivi razvrščajo v hierarhijo (slika 1), ki opredeljuje tudi odnose med njimi. Na človeka navadno deluje več kot le en motiv², ki si nemalokrat med seboj celo nasprotujejo. Medtem ko nekatere potrebe lahko vsaj začasno odložimo, v dani situaciji eden izmed motivov - dominantni motiv - navadno prevlada. Pomen, ki ga motivom pripisujemo, je odvisen od posameznikove osebnosti (nekateri ljudje imajo raje slabše plačano, manj ugledno službo z redno plačo in pogodbo za nedoločen čas - potreba po varnosti -, drugim pa je socialna varnost manj pomembna od prepoznavnosti, plače ipd. - potreba po ugledu) in tudi od zunanjih okoliščin. V razvitih kulturah je potreba po hrani večinoma zadovoljena in potisnjena $\mathrm{v}$ ozadje, na območjih, na katerih se ljudje še vedno srečujejo z lakoto in žejo, pa so fiziološke potrebe običajno dominantne.

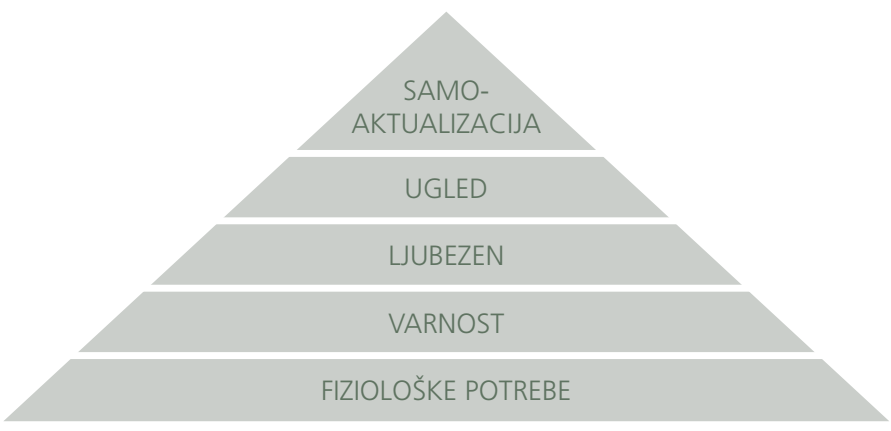

Vir: Musek, 1993 (str. 135).

Da bi s svojimi aktivnostimi in prizadevanji pritegnili pozornost ciljne populacije in jo zadržali, je pomembno, da z vsebino naslavljamo že obstoječe motive in potrebe, jih krepimo in posameznike usmerjamo k njihovemu zadovoljevanju. Če takšnega motiva ni ali v danih okoliščinah njegovo zadovoljevanje ni aktualno, ga ustrezno zapeljana kampanja lahko umetno ustvari oziroma okrepi. V vsakem primeru je razumevanje mehanizma zadovoljevanja človekovih potreb v luči aktualnih okoliščin in kulturnega ozadja na območju delovanja pomembno, da bi lahko razumeli odzive ljudi ter ustrezno načrtovali aktivnosti. Če moramo med prebivalci neke države ali območja nagovarjati predvsem občutek varnosti, ki ga ponuja sodelovanje, je morda ključnim posameznikom, vodjem, vaškim poglavarjem itn. te iste skupnosti pomembnejše od varnosti vzdrževanje ugleda, ki ga uživajo.

2 Tako imenovani motivacijski pluralizem, tj. sočasno delovanje več različnih motivov oziroma potreb na človeka v dani situaciji (Musek, 1993). 


\section{Pozornost}

Bagozzi (2002, str. 170) pozornost opredeljuje kot aktivnost, s katero posameznik osredotoča mentalno aktivnost na določen dražljaj. Pozornost je po svoji naravi selektivna, kar pomeni, da osredotočanje na nekatere dražljaje hkrati pomeni izključevanje drugih. Ule in Kline (1996) navajata različne vrste pozornosti, pri čemer so za tržno komuniciranje najpomembnejše (1) načrtna pozornost (posameznik išče določene informacije), (2) vsiljena pozornost, ki nastopi, ko se neki dražljaj vsili v našo zavest (na primer pok), ter (3) spontana pozornost, ki predstavlja nekakšno »odprtost « do dražljajev. Medtem ko se nakateri dejavniki pozornosti nanašajo predvsem na dražljaj (intenzivnost, prostornost, trajanje, pogostost, kontrast, gibanje itn.), drugi izhajajo iz prejemnika (izkušnje, interesi, potrebe, emocije itn.).

Pozornost je ključna sestavina kognitivnih procesov, ki sodelujejo pri procesiranju sporočila.

\section{Zaznavanje}

Zaznavanje je proces sprejemanja, predelave in primarnega interpretiranja informacij (Ule, 2009). Zaznavanje oziroma percepcija temelji na treh tipih dražljajev: (1) emocionalnih, (2) fizičnih ali (3) intelektualnih. Da bi pritegnili pozornost, se pri izvajanju aktivnosti psihološkega delovanja pogosto uporabljajo predvsem emocionalni dražljaji; tako pozitivni, ki naj bi delovali privlačno (slika idilične skupnosti, ki se bo ustvarila po prenehanju spopadov, ali pa - nam veliko bližja podoba - lepe ženske, ki sloni na visoko cenovnem avtomobilu itn.), kot tudi negativni, ki delujejo odbijajoče. Predvsem v začetnih fazah mirovnih operacij, ko je okolje še nestabilno in so napadi ter spopadi razmeroma pogosti, cilj pa stabilizacija in varnost, se v aktivnostih psihološkega delovanja pogosto pojavljajo izdelki, ki vključujejo zastraševanje, prisilo, diskreditacijo posameznikov (primer letaka, v katerem simbol Nata predstavlja merek na namerilni napravi). Medtem ko sta prisila in zastraševanje navadno usmerjena $\mathrm{v}$ nasprotnike, se $\mathrm{z}$ diskreditiranjem pomembnih posameznikov naslavljajo predvsem neodločene populacije.

Čustveno nabit dražljaj pritegne pozornost zaradi občutkov, ki jih generira, pozornost zadržuje, dlje pa se ohrani tudi v spominu. Podoben je učinek intelektualnih dražljajev, ki zahtevajo dodatno angažiranje kognitivnih funkcij - procesiranje posredovanega podatka. ${ }^{3}$

\section{Mišljenje}

Sporočilo, ki ga želimo posredovati, mora omogočati razumevanje ter biti oblikovano in posredovano na način, ki ni prezahteven za ciljno populacijo ali neusklajen z njenim načinom mišljenja in vrednotami in bi lahko bilo napačno razumljeno. Vsebine in tudi forme spoznavnih procesov se v različnih kulturah lahko bistveno

\footnotetext{
$V$ enem izmed okrajev $v$ ZDA so ob odsek ceste, kjer so se pogosto dogajale prometne nesreče s hudimi poškodbami ali smrtnim izidom, namesto oglasov postavili razbitine avtomobilov skupaj s tablo, na kateri so redno registrirali število nesreč v zadnjem letu na omenjenem odseku. Tako so združili uporabo emocionalnih in intelektualnih dražljajev.
} 
razlikujejo, saj so večinoma povezane s procesom socializacije (Zvonarević, 1984), ki poteka v nekem razmeroma omejenem okolju.

Nesmiselno je prebivalstvu posredovati bilten, v katerem so do potankosti opisane vse aktualne okoliščine, vključno z dejstvi, ki so jim sicer morda zamolčana, če je ta natisnjen v pisavi, ki ljudem ni poznana, če nismo upoštevali vprašanja pismenosti na splošno, če je vsebina zapisana v znanstvenem jeziku, ki preprostim ljudem ni razumljiv, in če so prezaposleni z zadovoljevanjem najbolj osnovnih življenjskih potreb.

\section{Spomin}

Spomin bi lahko opredelili kot posameznikovo sposobnost zadrževanja in hranjena informacij. Odvisen je tako od zaznavanja in pozornosti kot tudi od razumevanja. Poleg bioloških predispozicij na sposobnost pomnjenja vplivajo tudi predhodno znanje, stališča posameznika ter interesi (Zvonarević, 1984). Informacije, ki jih uporabljamo v kampanjah, morajo biti poudarjene na način, ki omogoča priklic sporočila tudi potem, ko posameznik sporočilu ni več izpostavljen. Ohranjanje informacij lahko zagotovimo že z uporabo ličnega slikovnega materiala, h kateremu nam uide pogled oziroma nam pritegne pozornost, lahko pa funkcijo še okrepimo, če mu dodamo informacije, ki nagovarjajo tudi druge čute, na primer z zvokom. Tako kot pri percepciji imajo pomembno vlogo tudi čustva in intelekt.

Omejitve človekovega spomina lahko do neke mere kompenziramo z ustrezno izbiro medija. Tiskani mediji tako zagotavljajo trajnost informacije, saj jo lahko prejemnik praktično kadar koli in kjer koli obnovi, ne omogočajo pa razkošja večpredstavnosti in celo interaktivnosti modernih elektronskih medijev.

\section{Čustva}

Če se večji del omenjenih pojmov iz sveta človekove duše nanaša na kognitivne procese in spoznavne funkcije, pa človek vendarle ni le »umni človek«. Njegovo življenje in delovanje opredeljujejo tudi čustva. Čustva predstavljajo duševno stanje pripravljenosti, ki izhaja iz kognitivne ocene dogodkov ali misli, je fenomenološko obarvano, spremljajo ga fiziološki procesi, je pogosto tudi fizično izraženo in lahko rezultira $\mathrm{v}$ specifične aktivnosti, katerih cilj je potrditev ali poskus obvladovanja čustva (Bagozzi, 2002, str. 172).

Ste se kdaj zalotili, da vas storitev ni pustila zadovoljene, čeprav je bila povsem korektno in pravilno opravljena? V potrošništvu čustva delujejo kot markerji, mediatorji in moderatorji našega vedenja, vplivajo pa tudi na kognitivne funkcije - na spomin, procesiranje informacij in presojanje ter ne nazadnje tudi na zadovoljstvo (Bagozzi, 2002).

\section{Stališča}

Krech, Crutchfield in Ballachey (v Ule, 2009) stališča definirajo kot trajne sisteme pozitivnega ali negativnega ocenjevanja, občutenja in aktivnosti $\mathrm{v}$ odnosu do različnih socialnih situacij in objektov. Stališča sestavljajo tri ključne komponente: 
(1) kognitivna, kot so znanje, izkušnje, sodbe in informacije o vsebini (mišljenje), (2) čustvena ali afektivna, ki se nanaša na pozitivno ali negativno naravnanost do obravnavane vsebine (čustva), ter (3) motivacijska, ki se kaže v težnji po delovanju na določen način (vedenje).

Stališča so naučena in kot takšna podvržena spreminjanju pod vplivom prepričevanja, s tem pa tudi orodje, prek katerega poskušamo usmerjati vedenje ljudi.

\section{Predsodki}

Predsodki so razmeroma trdna stališča do socialnih situacij, ki temeljijo na nepreverjenih dejstvih, in so pogosto globoko ukoreninjena v posameznikovo zavest. Gre za poenostavljene strukture, ki povzročajo selektivno pozornost ter popačenje določene vsebine (Ule, 2009). Verjetno ni treba posebej poudarjati, da aktivnosti, ki temeljijo na predsodkih, dejansko temeljijo na popačenih informacijah.

V okolju vojaških operacij moramo o predsodkih razmišljati z dveh vidikov. Po eni strani je bistveno, da prevetrimo svoj lastni nabor predsodkov, ki bi nam v kulturno raznolikem okolju lahko predstavljal ovire v komunikaciji, vplival na našo naklonjenost do določenih skupin prebivalstva, ne nazadnje ogrozil naše delovanje. Po drugi strani mora naša analiza ciljne populacije upoštevati tudi predsodke, ki bi jih prebivalstvo lahko imelo do nas, kar se bo v najboljšem primeru kazalo kot naša popolna neučinkovitost, lahko pa ogrozi tudi našo varnost ${ }^{4}$.

\section{Vedenje}

Cilj psihološkega delovanja je sprememba vedenja, torej mora sporočilo vzbujati občutke in dajati informacije, ki posameznika v končni fazi usmerijo k želenemu cilju.

\subsection{Poznavanje ciljne populacije - ustreznost izbire}

Analiza ciljne populacije predstavlja enega ključnih elementov v procesu razvoja ustreznega izdelka, nanaša pa se predvsem na izbor sporočil, ki bodo ustrezno izkoriščala osnovne psihične procese, hkrati pa se bodo s svojo simboliko in vsebino kar najbolj približala osnovnim značilnostim skupin, ki so jim namenjena. Analiza vključuje tako politično-vojaške dejavnike (ideologija, naravno okolje, politični sistem, zgodovina, religija, vloga medijev, vodstvo, kulturno okolje itn.) kot tudi psihološke in sociološke dejavnike (vrednote, stališča, predsodke, kulturo, pomembne socialne skupine, družbeno in skupinsko dinamiko, ključne posameznike itn.).

Analiza ciljne populacije temelji na petih elementih, ki so prikazani na primeru spodbujanja ženske populacije k udeležbi na volitvah:

- prepoznavanje vrednot ciljne populacije; kakšna je vloga ženske v dani kulturi, je spoštovana, upoštevana, enakovredna članica skupnosti;

\footnotetext{
${ }^{4}$ Na območju Afganistana je bila zaradi razbijanja predsodkov, ki jih je zaradi slabih izkušenj lokalno prebivalstvo imelo do uniformiranega osebja, izpeljana kampanja, v kateri so bile predstavljene nekatere članice koalicije, in sicer tako, da so bile jasno prikazane razlike med uniformami in oznakami.
} 
- preverjanje ravni odrekanja, ki ga zahteva sprememba vedenja; ženska se na podlagi nagovarjanja odloči za udeležbo na volitvah, kar ima za posledico nasilje moških članov družine nad njo;

- zagotavljanje razumevanja pomena novega (želenega) vedenja; kako se bodo z udeležbo žensk spremenile okoliščine v državi, kaj konkretno to pomeni za skupnost, družino, posameznika;

- učinkovitost prenosa koristi novega vedenja; ali, glede na značilnosti dane kulture, koristi novega vedenja lahko prenesemo na posameznike? Ali na primer v Afganistanu, ki ga poseljujejo različne etnične skupnosti, povprečna (nešolana) ženska razume koncept države in vlade?;

- preverjanje, ali je sprememba vedenja v danih okoliščinah za ciljno populacijo sploh mogoča - ali se ženska, ki smo jo nagovorili, sploh lahko (fizično) udeleži volitev? Ali bo že zaradi stika z nami ustrahovana ali izolirana?

S svojimi postopki in metodami se tako psihološko delovanje v vojaškem okolju vse bolj približuje konceptom, ki se uporabljajo na področju oglaševanja in trženja (Department of the Army, 2003).

Ker (navadno) izhajamo iz drugačnih socialno kulturnih in ekonomskih okoliščin kot ciljne populacije, s katerimi se srečujemo na kriznih žariščih, ne smemo pozabiti tudi na tako banalna vprašanja, kot je možnost dostopa do radijskega sprejemnika, kaj šele računalniške tehnologije in interneta.

\subsection{Komunikacija - od oddajnika k prejemniku}

Če smo si skozi prizmo socialne psihologije ogledali sporočilo in ciljno populacijo, velja spregovoriti tudi o procesu, ki poteka med oddajnikom in prejemnikom.

O komuniciranju govorimo takrat, ko med partnerji v socialni interakciji poteka kontinuiran tok sporočil (Ule in Kline, 1996; Adler, Rodman v Ule, 2005), ki so podana v nekem kodu, znakovnem sistemu, ki omogoča prenašanje pomena. Komuniciranje praviloma poteka $\mathrm{v}$ kontekstu nekih okoliščin, ki proces pošiljanja in prejemanja naredi bistveno bolj zapleten.

Glede na odnos med partnerji se komuniciranje deli na (1) znotrajosebno (proces predelave informacij v posamezniku), (2) medosebno, pri katerem gre za izmenjavo informacij med posamezniki, ter (3) nadosebno ali množično komuniciranje, ki je lahko skupinsko ali pa množično (Ule in Kline, 1996). Aktivnosti psihološkega delovanja med drugim predvidevajo tudi osebne stike, ki vključujejo predvsem neposredno komuniciranje taktičnih skupin z lokalnim prebivalstvom, ter komuniciranje poveljujočih s ključnimi lokalnimi osebami in s tem medosebno komunikacijo. Večina sporočil pa je vendarle posredovana prek drugih medijev in torej spada $\mathrm{V}$ področje množičnega komuniciranja. 


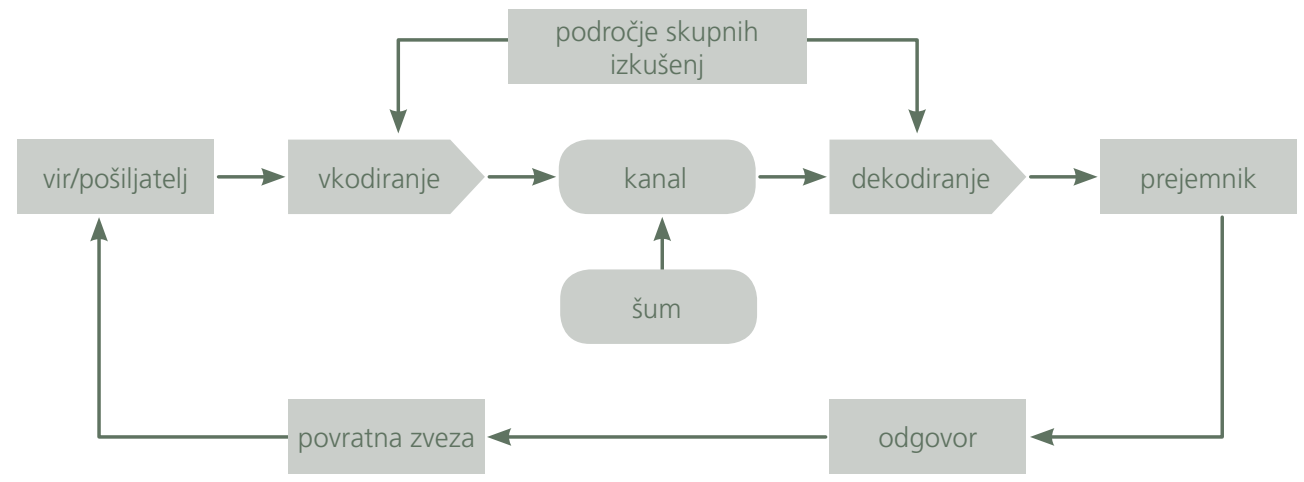

Slika 2 shematično ponazarja Schramov model (uspešnega) komuniciranja, iz katerega je mogoče izpeljati tri osnovne pogoje za učinkovitost: (1) sporočilo mora biti oblikovano in posredovano tako, da vzbudi zanimanje prejemnika, (2) vsebovati mora znake, ki so skupni in/ali razumljivi tako viru kot prejemniku, ter (3) nasloviti potrebe prejemnika (Ule in Kline, 1996).

Če stopimo korak nazaj, bomo videli, da vse podatke, ki jih zahteva uspešno komuniciranje, lahko najdemo v ustrezno zastavljeni analizi ciljne populacije, ki upošteva vse psihodinamične in sociodinamične elemente neke skupine, kulture in družbe.

\section{RAZVOJ IZDELKA}

"Ko ustvarjamo stvari, je to zato, ker poslušamo kupca, poberemo njihove predloge in dodamo še tisto, kar bi sami radi videli. Skuhamo nove izdelke. In v resnici nikoli ne veš, ali jih bodo ljudje imeli tako radi kot ti. $\|^{5}$

\section{Steve Jobes}

Psihološko delovanje predstavlja neskončen proces načrtovanja, analiziranja, usklajevanja, razvijanja, produciranja, distribuiranja in vrednotenja izdelkov ter aktivnosti, s katerimi želimo vplivati na ciljno populacijo. Razvoj ustreznega izdelka oziroma kampanje vključuje nekatere temeljne procese, ki se med seboj nadgrajujejo in dopolnjujejo:

- načrtovanje in oblikovanje programov (namera poveljnika, analiza ciljev konkretne operacije, oblikovanje konceptov v najširšem smislu, usmerjanje itn.),

\footnotetext{
5 »When we create stuff, we do it because we listen to the customer, get their inputs and also throw in what we'd like to see, too. We cook up new products. You never really know if people will love them as much as you do"
} 
- analiza ciljne populacije,

- razvoj izdelka na podlagi vseh prepoznanih dejavnikov (na splošno se delijo na tiste, ki izhajajo iz misije, ter tiste, ki izhajajo iz ciljne populacije),

- testiranje in evaluacija izdelka, ki vključuje predhodno testiranje na ustreznem vzorcu ali v okviru fokusne skupine pred produkcijo (usmerjeno predvsem na ustreznost produkta) ter evaluacijo učinka že izvedene naloge v luči doseganja želenega cilja,

- diseminacijo oziroma posredovanje sporočila prek ustrezno izbranega medija (Department of the Army, 2003).

Omenjeni procesi se, posebej v primeru večjih vojsk, pogosto prekrivajo s formalno organizacijo enot, katerih osnovno poslanstvo je izvajanje psihološkega delovanja.

\section{ORODJA DELOVANJA}

"Besede so novo orožje, sateliti nova artilerija ... Cezar je imel svoje častnike. Napoleon svojo armado. Jaz imam svojo divizijo: televizijo, časopise, revije .... $\|^{6}$ Archivilliain Elliot v filmu J. Bond: Jutri nikoli ne umre

Orodje delovanja na področju psihološkega delovanja podobno kot v tržnem komuniciranju predstavljajo vsa tehnična ali netehnična sredstva, prek katerih lahko poteka proces komunikacije s ciljno populacijo ali posamezniki. Z razvojem informacijske tehnologije se možnosti širijo, in tako se ob tiskanih produktih in različnih uporabnih izdelkih, kot so svinčniki, papirnati zmaji, kape ipd., vse bolj uveljavljajo različne oblike elektronskih medijev in množičnih občil. Medije, ki se uporabljajo za potrebe psihološkega delovanja, lahko kategoriziramo v tri osnovne skupine: (1) vizualni mediji, (2) avdio, (3) avdiovizualni, ki pritegnejo tako vid kot sluh (televizija, računalnik, pametni telefoni idr.) (www.psywarrior.com). Slednji s svojimi možnostmi uporabe (posebej v razvitih deželah in krajih) prodirajo v vse kotičke življenja. V primerjavi s prvimi oblikami, kot sta televizija ali kino, internet uporabnika iz vloge pasivnega opazovalca, ki informacije le sprejema, postavlja v vlogo partnerja, ki v odnosu lahko aktivno sodeluje.

Kot poseben način delovanja, ki ne spada v nobeno izmed naštetih kategorij, lahko omenimo še neposredno komunikacijo (angl. face-to-face communication) ter delovanje prek ključnih oseb (angl. key-leaders engagement) ${ }^{7}$. Prvi primer bi lahko primerjali s posrednikom ali prodajalcem, ki hkrati s prodajo storitve ali izdelka izvaja tudi anketiranje (ali obratno, poskuša prek ankete prodati izdelek), ali takšnim, ki svoje storitve ponuja prek organiziranih predstavitev javnega ali zaprtega tipa. V drugem primeru se način delovanja približuje modelu večfaznega komuniciranja - poleg delovanja prek drugih

\footnotetext{
Vir: Arnejčič, 2008, str. 283.

Ključne osebe, pripadnike neke skupine (npr. poglavar vasi itn.), se pogosto uporabljajo kot »medij«za prenos sporočil, kar pa je izvedljivo le pod pogojem, da oseba, s katero komunicira, uživa veliko zaupanja in kredibilnosti, kar je zaradi narave operacij (kratkotrajne rotacije) pogosto težko doseči. Ustrezna komunikacija in zaupanje sta pogosto odvisna tudi od osebnostnih lastnosti in spretnosti posameznika (praviloma častnika višjega ranga, ki uživa ugled), ki stopa v stik s ključnimi osebami.
} 


\begin{tabular}{|c|c|c|c|c|c|}
\hline $\begin{array}{r}\text { Tabela 1: } \\
\text { Nekatere }\end{array}$ & & MEDIJ & $\begin{array}{l}\text { NEKATERE } \\
\text { ZNAČILNOSTI }\end{array}$ & PREDNOSTI & POMANJKLJIVOSTI \\
\hline $\begin{array}{l}\text { posameznih } \\
\text { medijev (www. } \\
\text { psywarrior.com) }\end{array}$ & \multirow{3}{*}{$\begin{array}{l}\text { VIZUALNI - } \\
\text { TISKANI }\end{array}$} & PLAKAT & $\begin{array}{l}\text { enostranski, } \\
\text { statičnost - publika } \\
\text { so le mimoidoči }\end{array}$ & $\begin{array}{l}\text { nizki stroški, } \\
\text { trajnost, ciljna } \\
\text { usmerjenost - } \\
\text { točno določena } \\
\text { populacija }\end{array}$ & $\begin{array}{l}\text { hitrost/ažurnost prenosa, } \\
\text { dolgotrajna distribucija, } \\
\text { podvržena trenutni situaciji, } \\
\text { pogosto predvideva } \\
\text { pismenost }\end{array}$ \\
\hline & & LETAK & $\begin{array}{l}\text { dvostranski, } \\
\text { mobilnost, } \\
\text { mogoče uporabiti/ } \\
\text { prebrati kadar koli, } \\
\text { enotne velikosti } \\
\text { in oblike, mogoča } \\
\text { diseminacija iz } \\
\text { zraka }\end{array}$ & $\begin{array}{l}\text { nizki stroški, } \\
\text { trajnost, ciljna } \\
\text { usmerjenost - } \\
\text { točno določena } \\
\text { populacija }\end{array}$ & $\begin{array}{l}\text { hitrost/ažurnost prenosa, } \\
\text { dolgotrajna distribucija, } \\
\text { podvržena trenutni situaciji, } \\
\text { pogosto predvideva } \\
\text { pismenost, mogoča } \\
\text { izpostavljenost posameznika, } \\
\text { ki ga poseduje }\end{array}$ \\
\hline & & $\begin{array}{l}\text { PERIODIČNI } \\
\text { TISK }\end{array}$ & $\begin{array}{l}\text { obsežnejše } \\
\text { besedilo, izdaja v } \\
\text { rednih časovnih } \\
\text { obdobjih }\end{array}$ & $\begin{array}{l}\text { nizki stroški, } \\
\text { trajnost, ciljna } \\
\text { usmerjenost - } \\
\text { točno določena } \\
\text { populacija, } \\
\text { ustvarjanje navad }\end{array}$ & $\begin{array}{l}\text { hitrost/ažurnost prenosa, } \\
\text { dolgotrajna distribucija, } \\
\text { podvržena trenutni situaciji, } \\
\text { zahteva pismenost, mogoča } \\
\text { izpostavljenost posameznika, } \\
\text { ki ga poseduje }\end{array}$ \\
\hline & \multirow[t]{2}{*}{ AVDIO } & RADIO & $\begin{array}{l}\text { širok doseg, ažurna } \\
\text { uporaba novih } \\
\text { informacij, možnost } \\
\text { oddajanja iz zraka }\end{array}$ & $\begin{array}{l}\text { doseg, pokritost, } \\
\text { pravočasnost, } \\
\text { domačnost, } \\
\text { raznolikost, } \\
\text { hitrost, ne zahteva } \\
\text { pismenosti }\end{array}$ & $\begin{array}{l}\text { tehnična oprema, } \\
\text { možnost (namernega ali } \\
\text { nenamernega) motenja, } \\
\text { razpoložljivost sprejemnikov, } \\
\text { frekvence, napajanje, } \\
\text { minljivost, konkurenca, } \\
\text { neselektivnost }\end{array}$ \\
\hline & & $\begin{array}{l}\text { SISTEMI } \\
\text { OZVOČENJA }\end{array}$ & $\begin{array}{l}\text { »neposreden« stik, } \\
\text { odzivnost }\end{array}$ & $\begin{array}{l}\text { selektivnost, } \\
\text { preprostost, } \\
\text { mobilnost, hitrost, } \\
\text { ne zahteva } \\
\text { pismenosti }\end{array}$ & $\begin{array}{l}\text { ranljivost, fizične ovire, } \\
\text { izpostavljenost, minljivost }\end{array}$ \\
\hline & \multirow{3}{*}{$\begin{array}{l}\text { AVDIO- } \\
\text { VIZUALNI }\end{array}$} & TELEVIZIJA & $\begin{array}{l}\text { vplivnost, intimnost, } \\
\text { vzpostavljanje } \\
\text { navad }\end{array}$ & $\begin{array}{l}\text { hitrost, ne zahteva } \\
\text { pismenosti, } \\
\text { manj odvisna od } \\
\text { tradicionalnih } \\
\text { vzorcev }\end{array}$ & $\begin{array}{l}\text { doseg, draga oprema in } \\
\text { vzdrževanje, specializirana } \\
\text { ekipa, nestalnost, } \\
\text { razpoložljivost }\end{array}$ \\
\hline & & $\begin{array}{l}\text { KINEMATO- } \\
\text { GRAF }\end{array}$ & $\begin{array}{l}\text { spoti in izvlečki, } \\
\text { popularen na } \\
\text { območjih brez TV }\end{array}$ & $\begin{array}{l}\text { vtis verodostojnosti, } \\
\text { ne zahteva } \\
\text { pismenosti, } \\
\text { čustvena } \\
\text { identifikacija, velika } \\
\text { stopnja priklica }\end{array}$ & $\begin{array}{l}\text { stroški, počasnost in } \\
\text { neažurnost, možnost cenzure } \\
\text { in restrikcije }\end{array}$ \\
\hline & & INTERNET & $\begin{array}{l}\text { aktivno iskanje } \\
\text { informacij, različne } \\
\text { oblike omogočajo } \\
\text { možnost široke } \\
\text { publike ali ozko } \\
\text { usmerjenost (npr. } \\
\text { klepetalnica) }\end{array}$ & $\begin{array}{l}\text { neomejen doseg, } \\
\text { hitrost in takojšnja } \\
\text { dostopnost, } \\
\text { možnost } \\
\text { delovanja z velike } \\
\text { oddaljenosti, nizki } \\
\text { stroški }\end{array}$ & $\begin{array}{l}\text { problem nepredvidenih } \\
\text { populacij, dostopnost } \\
\text { računalnikov in internetnih } \\
\text { storitev, zahteva pismenost, } \\
\text { anonimnost, konkurenca, } \\
\text { izpostavljenost sporočil }\end{array}$ \\
\hline
\end{tabular}


sredstev je ključnega pomena angažiranje vplivnih posameznikov. Ti so v manj razvitih okoljih in kulturah pogosto ključni dejavnik odločanja tako skupnosti kot posameznika.

V tabeli 1 so strnjene nekatere temeljne značilnosti uporabe in prednosti ter pomanjkljivosti posameznih sredstev komunikacije.

Nekatera sredstva na določenih območjih niso dostopna ali pa je njihova (ne)uporaba odvisna od tamkajšnje kulture, zato je izbira ustreznega medija ena ključnih točk v procesu načrtovanja. Izkušnje kažejo, da je pri tem pomembna temeljita analiza, ki se ji pogosto nameni premalo pozornosti. Tako se je izkazalo (na presenečenje nekaterih pripadnikov tujih - predvsem zahodnih vojsk), da so dostopnost medijev in navade prebivalcev Bosne in Hercegovine bistveno bolj podobne tistim v razvitih deželah kot deželam tretjega sveta (Larsen, 1999).

Da bi bilo sporočilo kar najbolj učinkovito, se v okviru kampanj pogosto uporabi kombinacija različnih načinov prenosa informacij, ki se med seboj podpirajo in dopolnjujejo (na primer letaki, ki poleg sporočila objavljajo radijsko frekvenco).

\section{6 ŠTUDIJA PRIMERA - UPORABA PRINCIPOV PSIHOLOŠKEGA DELOVANJA V SLOVENSKI VOJSKI}

\section{"Nisem ustrelil s puško. Naredil sem ji promocijo. $\|^{8}$ \\ Jared Kintz}

Angažiranje Slovenske vojske na področju psihološkega delovanja na območjih operacij kriznega odzivanja je bilo do zdaj bolj ali manj omejeno na sodelovanje $\mathrm{v}$ mednarodnih poveljstvih in enotah; večji del s posamezniki ali manjšimi enotami, katerih naloge so bile omejene na posamezen segment psihološkega delovanja. Obstaja pa primer tiskanega izdelka, ki sledi ideji psihološkega delovanja in je bil izdelan in uporabljen na območju Kosova leta 2007.

Zgibanka, predstavljena med slikami, je bila izdelana pod okriljem aktivnosti, ki so jih poimenovali z delovnim naslovom »Wining hearts and minds«. Enota je aktivnosti začela izvajati potem, ko je prevzela območje delovanja ter se ustalila $\mathrm{v}$ okviru svojih nalog. Osnovni cilj aktivnosti je bil vzpostaviti še boljše sodelovanje z lokalnim prebivalstvom ter pridobiti informacije o tem, kako lokalno prebivalstvo dojema in sprejema prisotnost slovenskih vojakov. V ozadju te konkretne aktivnosti pa je bistveno širša ideja, da bo z »osvajanjem src in duš« lokalnega prebivalstva ter krepitvijo njihove naklonjenosti večja tudi varnost slovenskih vojakov. Zgibanko so pripadniki delili prebivalcem, s katerimi so prihajali $\mathrm{v}$ neposreden stik na kontrolnih točkah ali v okviru drugih nalog. Napisana je bila v albanskem, srbskem in angleškem jeziku v dveh vsebinsko zelo podobnih različicah (Škerbinc, 2013).

8 »I didn't fire a gun. I gave it a promotion." 
Naslovnica tridelne zgibanke je namenjena pozdravu in nagovoru. S poudarjenim naslovom na rdeči podlagi, katerega namen je pritegniti pozornost, piše "POZDRAVLJENI! ${ }^{\prime}$ ", ter v nadaljevanju: »Ustavili smo vas na kontrolni točki ali pa ste na kakšen drug način prišli v stik z vojakom Kforja-pripadnikom slovenskega kontingenta, ki deluje v okviru bojne skupine Sokol, ki je del mednarodnih sil. Naša naloga v okviru Kforja je, da vsem prebivalcem Kosova zagotovimo varno okolje."

Tako na zunanji kot tudi na notranji strani je uporabljen slikovni material, ki se nanaša na delo pripadnikov SV in njihovo mednarodno in civilno-vojaško sodelovanje. Na obeh straneh se večkrat ponovita kratici Nato in Kfor ter oznake slovenskega kontingenta v različnih oblikah in izvedbah (zastava, grb SV v vodnem tisku ipd.). Tako se vzpostavlja prepoznavnost in kredibilnost vira, ki nima nikakršnega interesa prikrivanja svoj identitete, saj se pojavlja z odkritimi in poštenimi nameni (t. i. »beli« PSYOPS $^{10}$ ).

Druga stran izdelka povzema in dodatno razčlenjuje nagovor na naslovnici: »V bojni skupini Sokol je aktiven slovenski bataljon, ki mu je pridodana madžarska četa. Vsi ti vojaki imajo izkušnje z več mirovnih operacij. Na Kosovu tako trenutno deluje več kot 600 vojakov ter civilnih strokovnjakov, kot so inženirji, veterinarji in zdravniki. Vsi skupaj si želimo, da bi živeli v sodobnem in gostoljubnem okolju. Preteklosti žal ne moremo spremeniti, lahko pa vplivamo na svetlejšo prihodnost.«

Del zgibanke je namenjen povratnim informacijam lokalnega prebivalstva, tj. ciljne populacije, o delovanju pripadnikov slovenskega kontingenta. "Zanima nas vaše mnenje o odnosu naših vojakov v vašem okolju. Priporočamo se za vsako informacijo, kritiko, mnenje ali pohvalo. «

Zgibanka z obliko in vsebino nagovarja z vsemi tremi tipi dražljajev, na katerih temeljijo zaznavni procesi.

(1) Čustvovanje; fotografije iz vsakdanjega življenja pripadnikov so večinoma zaznamovane s pozitivnimi emocijami in prikazujejo dobre medsebojne odnose in komunikacijo med pripadniki in lokalnim prebivalstvom. Dodatno čustveno noto jim dajejo fotografije otrok, ob katerih se še posebej hitro raznežimo. Te so tudi v oglaševanju pogosto uporabljene prav zaradi vzbujanja pozitivnih emocij.

(2) Poskus aktivacije zaznavnih procesov prek fizičnih dražljajev (v tem primeru vizualnih) je opazen predvsem na naslovnici, kjer pozornost pritegne krepko tiskan pozdrav. Podobno vlogo ima tudi uporaba slikovnega materiala, ki našo pozornost pritegne bistveno bolje od dolgega in drobnega besedila, ki zahteva dodatno angažiranje.

\footnotetext{
9 Uporabljen je neuraden prevod albanskega primera zgibanke.

${ }^{10}$ Psihološko delovanje se z vidika navajanja vira deli na »belo« - aktivnost je označena s pravim virom, »sivo«, pri čemer vir ni naveden, ter »črno« - aktivnost je namerno pripisana drugemu (Paul, 2008). Aktivnosti oboroženih sil naj bi potekale zgolj $v$ »belem polju«.
} 
(3) Miselni del zajema besedilo, ki v nekaj preprostih stavkih opisuje namen sodelovanja slovenskega kontingenta in Kforja na Kosovu ter postopno in nevsiljivo poskuša usmeriti posameznika k (skupnemu) cilju v ozadju. V tem delu besedila so razčlenjena nekatera dejstva o prisotnosti slovenskega kontingenta na Kosovu.

Z majhnimi oblikovnimi in vsebinskimi razlikami sta različici, ob tem da so bila osnovna sporočila ohranjena, pri lokalnem prebivalstvu spodbudili zanimanje in željo po prejemu obeh (Zakaj je njegova drugačana od moje?), tako je bila zagotovljena tudi večja verjetnost, da bo prejemnik besedilo prebral.

Skozi celoten izdelek se ponavljajo simboli, katerih namen je prepoznavnost ter transfer pozitivnih emocij:

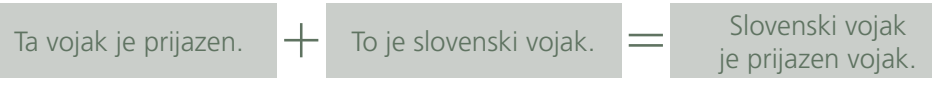

Če izhajamo iz potreb, lahko izločimo predvsem motiv varnosti v najširšem smislu (preprečevanje neposredne ogroženosti, vzpostavljanje varnih zatočišč in domov itn.), ki jo implicira tako v besedilu kot tudi v slikovnem materialu, in nakazuje, da bo s sodelovanjem ta potreba zadovoljena.

Ob upoštevanju dveh ključnih entitet, Srbov in Albancev, je bila enaka zgibanka natisnjena $\mathrm{v}$ obeh jezikih, s čimer je bila poudarjena nepristranska drža slovenskih pripadnikov.

Zgibanka omogoča grobo analizo tudi z vidika procesa komunikacije. Slika 4 predstavlja shematski prikaz osnovnega modela procesa komuniciranja ob upoštevanju ključnih elementov.

Kot vir se v tem primeru pojavlja slovenski kontingent, ki zaupanje gradi na kombinaciji slikovnega gradiva in besedila, v katerem je implicirano dosedanje dobro sodelovanje. Sporočilo, ki ga želi prenesti, je, da se zanima za blaginjo prebivalstva, mu želi pomagati, in z njihovim sodelovanjem pogoje za življenje še izboljšati. Večina prejemnikov, ki so se (prek povratne zveze) odločili odgovoriti na sporočilo, so izražali naklonjenost do prisotnosti Slovencev in Kforja na Kosovu. Torej lahko sklepamo, da je bilo sporočilo razumljeno podobno, kot je bilo zamišljeno - med slovenskim kontingentom in lokalnim prebivalstvom je vzpostavljen dober odnos. 
Slika 4:

Shematski prikaz osnovnega modela procesa komuniciranja na primeru (prirejeno po Ule in Kline, 1996)

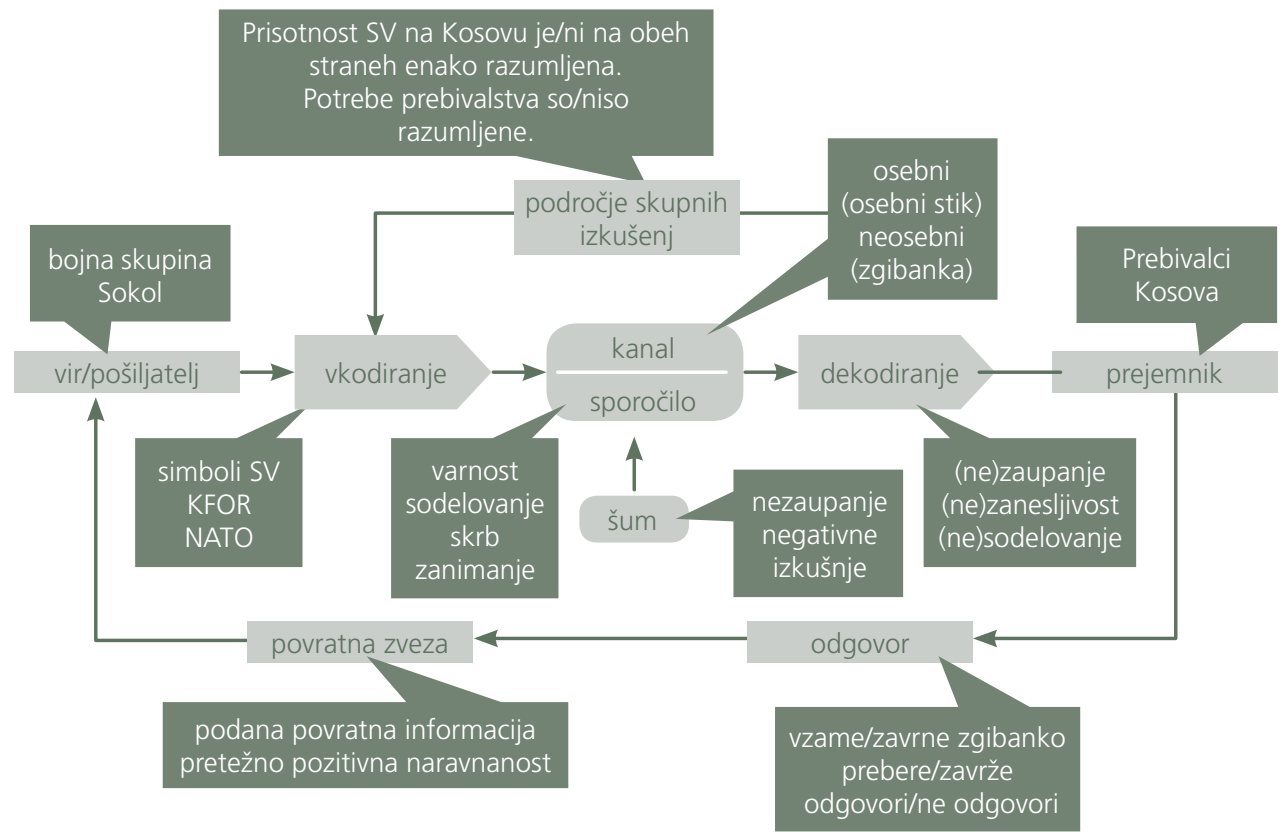

V tem primeru je šlo za prvi (samostojni) poskus izvajanja psihološkega delovanja na območju operacij kriznega odzivanja v takšni obliki. Sodeč po odzivnosti prebivalstva je bil dobro sprejet, saj je enota dobila veliko povratnih informacij, ki so bile večinoma pozitivne. Povratne informacije so se v kontingent vračale predvsem po dveh »kanalih«; (1) kot povsem konkretni odgovori na za to predvidenem delu zgibanke; (2) kot informacije, posredovane v osebnih stikih z vojaki, ki so svoje delo opravljali med prebivalstvom, ter prek poveljnika in ključnega osebja kontingenta, ki je imelo vzpostavljene odnose z vidnejšimi predstavniki skupnosti. Pripadniki slovenskega kontingenta so bili pogosto označeni kot prijazni, strpni, komunikativni in nenasilni. Da bi krepili pozitivno samopodobo in pripadnike še naprej spodbujali k pozitivno naravnanemu vedenju, so bili iz odrezkov zgibank izdelani plakati in objavljeni na javnem mestu. Tako je bila vzpostavljena »povratna zanka« transfera pozitivnih emocij, prikazanega na sliki 3 - pozitivne ocene so na (samo)percepcijo vojakov vplivale pozitivno in krepile njihovo pozitivno (prijazno) samopodobo (Škerbinc, 2013).

Čeprav enota ni imela osebja, specializiranega za posamezne segmente psihološkega delovanja, uspeh ni izostal, kar lahko pripišemo tudi skupni zgodovini, ki nam pogosto olajša vzpostavljanje stikov in razumevanje problematike v okolju, ter predhodnim izkušnjam. Seveda pa še tako dobre izkušnje in znanje ne bi odtehtale slabega priokusa, če bi pripadniki z neprimernim vedenjem rušili kredibilnost kontingenta, Slovenske vojske in zavezništva. 


\section{7 "PSYOPS« - VOJAŠKO ALI PSIHOLOŠKO DELOVANJE?}

\section{„Človek ne more polno živeti, ne da bi bil vpleten v psihološke procese, ki nas obkrožajo. ${ }^{11}$}

\section{Philip G. Zimbardo}

Članek se začenja z ugotovitvijo, da ima vsaka vojaška aktivnost tudi svojo psihološko dimenzijo. In po tem, ko smo se sprehodili skozi nekatere temeljne definicije, katerih vir je vojaška stroka, in pojme, ki so predvsem predmet psihologije, se ponovno vračamo na začetek. Je psihološko delovanje torej domena vojaške ali psihološke stroke?

Človekova narava - fiziologija, čustvovanje in mišljenje - se skozi tisočletja ni bistveno spreminjala. Prav tako se ne spreminjajo nekatera temeljna spoznanja o zaznavnih in višjih spoznavnih procesih, ki definirajo naše delovanje. Spreminjajo se le zunanje okoliščine, ki naše delovanje postavljajo v nove in nove kontekste, skozi katere se razvijamo in učimo. Vsa ta spoznanja se že od nekdaj s pridom (ali pa zlonamerno) uporabljajo na številnih področjih, od tržnega komuniciranja, menedžmenta, organizacije dela do delavnic osebne rasti, ki jih organizira lokalno društvo, in prodajalca, ki nas s ponarejenim nasmehom petnajstič v istem dnevu vpraša, kako smo, pa ga to sploh ne zanima.

Res pa je, da nas na področjih, ki so usmerjena k interdisciplinarnosti, vse prerado zanese v eno ali drugo smer, in predmet obravnave bodisi tiščimo stran od sebe, ker »to pa res ni naše področje, naj se s tem ukvarja ...«, bodisi vlečemo k sebi, saj »nihče drug ni kompetenten«. Podobno se dogaja s psihološkim delovanjem. Po eni strani ga je vse preveč preprosto poriniti psihologom, če ne zaradi drugega, zaradi predpone »psih-«, ob tem ko je psihologija le segment celotnega procesa delovanja. Prav tako so sprejemljivi argumenti, ki psihologe popolnoma izključujejo, ker gre »itak za povsem vojaško aktivnost«, ker so psihološke vsebine v primerjavi z vojaškimi nepomembne, in ker se »na psihologijo ja vsi spoznamo«. Vsi imamo namreč izkušnjo s čustvovanjem, mišljenjem, predsodki, vedenjem, kolektivi ... in torej lahko sklepamo na iste vsebine tudi pri drugih ljudeh, skupinah, kulturah, družbah itn. Ne nazadnje lahko v enačbo dodamo še vprašanje psihološke etike, saj se pojem psihološkega delovanja pogosto povezuje s »pranjem možganov«, manipuliranjem, zavajanjem ipd. Seveda gre pri tem za dejanja, s katerimi psihologi nikakor ne želimo biti povezani.

Dejstvo je, da se psihologija ne more ograditi od psihološkega delovanja, saj že definicije vse po vrsti vsebujejo pojme, kot so čustva, motivi, stališča, vplivanje, razumevanje in vedenje, ki so predmet psihologije. Arnejčič (2008) v svoji definiciji eksplicitno izpostavi neposredno povezavo, ko navaja $» / . . . /$ dejavnost v vojni in miru, ki uporablja spoznanja psihologije, da vpliva /.../«. Vsebine psihološkega delovanja oziroma propagande najdemo tudi v literaturi vojaške psihologije starejšega datuma;

\footnotetext{
"I "ne can't live mindfully without being enmeshed in psychological processes that are around us."
} 
vsaj v tisti, ki se področja psihologije v vojski loteva širše in se ne omejuje le na psihopatološke pojave. Arnautović v Vojni psihologiji, učbeniku za vojaške akademije nekdanje JLA iz leta 1988, psihološkim osnovam vojaške propagande namenja celo poglavje. Glede na dejstvo, da je slednje umeščeno med specifična področja vojaške psihologije ter pod okrilje specialne vojne, lahko sklepamo, da je vendar zaznana mejnost področja - ne moremo se delati, da se psihologije ne tiče, v bistvu pa spada v naloge drugih organizacijskih enot. Sicer pa se vsebina, če jo tehnološko malce posodobimo in odmislimo ideološko obarvano kolektivno kvaziparanojo pred vsem, kar bi lahko predstavljalo gnili kapitalizem, pogosto zelo približuje tisti, ki bi jo našli v kakšni novejši dokritni psihološkega delovanja. Lahko bi dejali, da so posamezni odseki skoraj enaki, avtor kot aktivnosti psihološke propagande pa opisuje tudi veliko takšnih, ki bi jih zdaj logično opredelili kot obveščevalno in/ali protiobveščevalno dejavnost.

Najbrž res nima pravega smisla, da bi le zaradi predpone sklepali, da gre pri psihološkem delovanju za aktivnosti psihološke dejavnosti, katere nosilec je psiholog. Ne nazadnje je velika večina nalog, ki jih psihološko delovanje vključuje, povsem praktičnih - ne zahtevajo posebnega strokovnega predznanja in bistveno bolje jih lahko opravi posameznik, ki obvlada specifične spretnosti (na primer delo z računalniško grafiko). Zagotovo pa obstaja »skupno polje izkušenj«, v katerem s spoznanji psihološke stroke lahko prispevamo tako k učinkovitosti delovanja kot tudi skrbi za etičnost posameznih aktivnosti. Takšna področja so predvsem:

- izobraževanje in usposabljanje iz psiholoških vsebin, ki bi prispevalo k (1) razumevanju psihodinamičnih pojavov v okoliščinah operacij kriznega odzivanja - tako tistih, ki so neposredno povezani z aktivnostmi psihološkega delovanja, kot tudi tistih, ki vplivajo na okoliščine misije, (2) prepoznavanju in vrednotenju etičnih dilem v procesih vplivanja, (3) poznavanju elementov in vsebin psihološkega raziskovanja ciljnih populacij ter (4) poznavanju postopkov evaluacije izdelkov;

- analiza ciljne populacije, ki pogosto temelji le na informacijah, ki so zunanjemu opazovalcu dostopne, in na tistih, na katere sklepa na podlagi osebnih okoliščin (izkušnje, vrednote, stališča, interesi, čustvovanje idr.), zanemarja pa psihodinamične procese na individualni in družbeni ravni. Posledično se dogajajo situacije, ki jih Ule in Kline (1996, str. 68), ko govorita o problemih sprejemanja in dekodiranja ter pomenu psihološkega raziskovanja ciljnih javnosti, poimenujeta »Srečal sem potrošnika in to nisem jaz! «;

- testiranje in evaluacija izdelka (izdelek se tu nanaša na vsebino in formo sporočila), pri čemer se srečujemo z nekaterimi osnovnimi tehnikami merjenja stališč - od anketnih listov do fokusnih skupin. Z neomejenimi sredstvi bi (vsaj teoretično) lahko uporabili tudi (v danih razmerah) bolj »znanstvenofantastične« metode, kot je spremljanje srčnega ritma, dihanja ali prevodnosti kože ob predvajanju dražljaja tako, kot raziskujejo za bolj učinkovito trženje različnih izdelkov. Psihologovo poznavanje tehnik bi lahko prispevalo k ustrezni izbiri in izvedbi. 
Če je vprašanje sodelovanja psihologov povezano z vprašanjem strokovne etike, se moramo vprašati, kako je to vprašanje rešeno na drugih področjih množičnega komuniciranja in predvsem marketinga. Res je, da je bila propaganda v preteklosti pogosto neposredno povezana z manipuliranjem, področje psihološkega delovanja pa se poskuša od tovrstnih aktivnosti ograditi. Če se vrnemo na uvod, v katerem je psihološko delovanje opredeljeno kot komponenta informacijskega delovanja, vidimo, da je zavajanje povsem ločena komponenta z lastnimi zmogljivostimi in metodami dela. Težnjo po transparentnem delovanju pa zasledimo v nekaterih osnovnih načelih, kot so verodostojnost, resnicoljubnost, atribucija vira, omejitve delovanja na lastne in zavezniške sile ipd.

Kaj pa drugi cilji, ki jim tovrstne aktivnosti sledijo, kot je obvarovanje življenj na eni in drugi strani? Pri psihološkem delovanju gre namreč za nekinetično delovanje in s tem manjšo možnost žrtev, kot smo že ugotovili na začetku, pa vzpostavljeno medsebojno zaupanje ščiti tudi naše pripadnike. Če lahko podležemo in vztrajamo pri ideji, da gre pri psihološkem delovanju vedno za manipulacijo, smo prebivalstvu odrekli posedovanje osnovnih sposobnosti presoje in se moramo sprijazniti z dejstvom, da smo tudi sami vsak trenutek žrtev takšnih ali drugačnih manipulacij. Sebi in drugim smo odrekli sanje o višjih ciljih, kakršen je »Kantov večni mir«. Človek je namreč družabno bitje, ki (večinoma) ne živi izolirano, in vsakokrat, ko vstopa v odnose z drugimi, je podvržen njihovim poskusom vplivanja in hkrati poskuša nanje vplivati sam.

In ne nazadnje je vprašanje etike vprašanje konkretnega posameznika in konkretnega primera oziroma aktivnosti. Tu pa si mora vsak psiholog ohraniti pravico, da $\mathrm{v}$ trenutku, ko presodi, da bo moral kršiti etični kodeks, svoje sodelovanje z ustrezno obrazložitvijo odkloni. Če kje, bo v primeru psihološkega delovanja moder poveljnik sprejemljiv za predloge o etičnih in moralnih omejitvah in psihologu nekoč hvaležen, ker mu je preprečil, da bi naredil napako. Za trenutek premislimo. So situacije, za katere lahko trdimo, da gre za manipulacijo in zlorabo, kot je primer Abu Graiba ${ }^{12}$, v katerih ne smemo sodelovati - še več, nanje moramo opozarjati in jih preprečevati. Kaj pa tiste, ob katerih naše sodelovanje lahko prispeva k preprečevanju žrtev na eni in drugi strani ali k omejevanju škode?

Trženje in psihologija tržnega komuniciranja? Vsekakor. V vojaškem okolju ne »tržimo« in naša dejavnost ni profitno naravnana, in prav tako bi težko v »trdno obliko« spravili proizvod, ki ga želimo spraviti v promet. Toda če odmislimo storitev ali izdelek in jo zamenjamo z idejo ali vrednotami, naša sporočila slej ko prej temeljijo na enakih psiho- in sociodinamičnih postulatih. Helmus et al. je študijo iz leta 2007 Enlisting Madison Avenue priročno podnaslovil The Marketing Approach to Earning Popular Support in Theaters of Operation in v njej nedvoumno potegnil vzporednico med aktivnostmi, ki jih izvaja vojska, in tistimi, ki potekajo v poslovnem svetu.

\footnotetext{
${ }_{12}$ V primeru Abu Graiba je ena izmed akterk pozneje v novinarski izjavi dejala, da jim je bilo ukazano, naj se za potrebe PSYOPS slikajo med nehumanim izživljanjem nad zaporniki. Ne glede na resnico gre v vsakem primeru (ali je res obstajal takšen ukaz ali pa je izjava neresnična) za okrutno in obsojanja vredno dejanje.
} 
Delo se začenja z mislimi, kot je »/.../ poslovne tržne prakse nudijo uporaben okvir za izboljšanje vojaških poskusov oblikovanja stališč in vedenja pri različnih populacijah /.../« (str. xvi), končuje pa z ugotovitvami, ki povsem neposredno nagovarjajo k uporabi marketinških strategij v vojaške namene: poznavanje ciljne populacije skozi proces segmentacije in ciljnega usmerjanja, razumevanje konceptov »brandinga«, uporaba vojske kot znamke, doseganje zadovoljstva civilnega prebivalstva - upravljanje in zadovoljevanje pričakovanj itn., če naštejemo le nekatere.

Prav tako nam je povezavo med koncepti psihologije tržnega komuniciranja uspelo nakazati skozi študijo primera.

Sklep Članek poskuša predstaviti nekatere temeljne značilnosti psihološkega delovanja, kot se izvaja v okviru sodobnih vojsk, oziroma poskusov vplivanja na ljudi izbranih ciljnih populacij, pa naj to imenujemo psihološko vojskovanje, vojna propaganda ali pa - psihologija potrošnika. Včasih se ob prebiranju vojaške literature zdi, da se poskuša psihološko delovanje predstaviti kot stroga vojaška veda, ki s civilnim okoljem in načinom delovanja nima nikakršne zveze, in da je težišče literature bolj kot na procesih v ozadju na obrazcih, navodilih in predlogah za izdelavo načrtov. A težko bomo obšli dejstvo, da poskusi vplivanja na izbrane ciljne populacije temeljijo na procesih, ki jih poznamo iz socialne psihologije. Dinamika v ozadju procesov je bolj ali manj enaka, ne glede na to, ali gre za prodajo izdelka, uveljavljanje znamke, kampanjo proti vožnji pod vplivom alkohola ali poskus pridobivanja podpore na območju mirovnih misij. Gre preprosto za to, da želimo stališča posameznikov spremeniti na način, da se bo spremenilo tudi njihovo vedenje - v prid naši ideji.

Tudi primer s Kosova, ki smo ga izpostavili in analizirali z vidika nekaterih osnovnih socialno psiholoških pojmov, dokazuje, da lahko procese, na katerih temelji sodobna potrošniška družba, povsem verodostojno uporabimo za namene vojaških aktivnosti na območjih mirovnih opreacij. Pri tem pa se moramo popolnoma ograditi od vseh primerov manipuliranja in zlorab.

Psihološko delovanje, nekinetično bojevanje, psihologija potrošnika itn.? Vse to. Le da ne prodajamo pralnega praška ali brivskih preparatov, temveč način življenja in ideale, ki se nam, ki nam ničesar ne manjka, zdijo samoumevni. Ljubljana: Fakulteta za družbene vede.

2. Arnautović, D. (et al.), 1988. Vojna psihologija. Beograd: Vojnoizdavački in novinski centar.

3. Bagozzi, Richard P. (et al.), 2002. The Social Psychology of Consumer Behaviour. Bukingham, Philadelphia: Open University Press.

4. Department of the Army. Psychological Operations Tactics, Techniques and Procedures. FM 3-05.301. Dostopno prek: http://www.fas.org 
5. Furlan, B. (et al.), 2006. Vojaška doktrina. Ljubljana: Defensor.

6. Helmus, Todd C. (et al.), 2007. Enlisting Madison Avenue: the Marketing Approach to Earning Popular Support in Theaters of Operation. RAND Corporation. Dostopno prek: http://www.rand.org.

7. Lamovec, T., 1988. Priročnik za psihologijo motivacije in emocij. Ljubljana: Filozofska fakulteta.

8. Larsen, Stephen C., 1999. Conducting Psychological Operations in Sophisticated Media Environments (magistrska naloga). Fort Leavenworth, ZDA: U.S Army Command and General Staff College.

9. Musek, J., 1988. Teorije osebnosti. Ljubljana: Filozofska fakulteta.

10. Musek, J., 1993. Znanstvena podoba osebnosti. Ljubljana; Educy d.o.o.

11. Paul, C., 2008. Information Operations: Doctrine and Practice. Westport, Connecticut: Praeger Security International.

12. Škerbinc, M., 2013. Osebni razgovor (9. 8. 2013).

13. Ule, M., 2005. Psihologija komuniciranja. Ljubljana: Fakulteta za družbene vede.

14. Ule, M., 2009. Socialna psihologija. Analitični pristop k življenju v družbi. Ljubljana: Fakulteta za družbene vede.

15. Ule, M. in Kline, M., 1996. Psihologija tržnega komuniciranja. Ljubljana: Fakulteta za družbene vede.

16. Zvonarević, M., 1984. Socijalna psihologija. Zagreb: Školska knjiga.

17. Canadian Forces. Psychological Operations: Joint Doctrine Manual. Dostopno prek: http://www.efd-cfd.forces.gc.ca.

18. USAF, Joint Chiefs of Staff. Doctrine for Joint Psychological Operations. Dostopno prek: http://www.dtic.mil.

19. United States Air Force. Psychological Operations: Air Force Doctrine Document 2-5.3. Dostopno prek: http://www.iwar.org.uk.

\section{Internetni viri}

20. Global Security.org - Reliable Security Information. Dostopno prek: http://www. globalsecurity.org (2. 3. 2009).

21. Psywarrior - Psychological Operations. Dostopno prek: http://www.psywarrior.com (2. 3. 2009).

22. RAND Corporation. Dostopno prek: http://www.rand.org (20. 3. 2009).

23. http://www.earlymoderntxts.com (10. 8. 2013).

24. http://www.eruditiononline.com (20. 3. 2009). 
Janja Vuga, Katarina Rajh, Gašper Kavšek,

Katja Cimermančič, Rafaela Križman, Urška Učakar

\section{SOCIALNA, INSTITUCIONALNA IN ORGANIZACIJSKA PODPORA V POHLEPNIH INSTITUCIJAH: ZADOVOLJSTVO SLOVENSKIH VOJAŠKIH DRUŽIN}

\section{SOCIAL, INSTITUTIONAL AND ORGANISATIONAL SUPPORT IN GREEDY INSTITUTIONS: SATISFACTION OF SLOVENIAN MILITARY FAMILIES}

Povzetek Coser je vojaške organizacije in družino opredelil kot dve pohlepni instituciji, katerih tekmovanje za posameznikov čas lahko vodi v konflikt med delom in družino. Za uspešnejše usklajevanje so na voljo različne oblike podpore. Na podlagi veljavne teorije smo v članku izpostavili tri tipe podpore: socialno, institucionalno in organizacijsko. Zadovoljstvo z naštetimi tipi smo preverjali v 33 slovenskih vojaških družinah, med katerimi smo ugotavljali tudi to, koliko je Slovenska vojska med vojaškimi družinami razumljena kot pohlepna institucija. Analiza intervjujev kaže, da slovenske vojaške družine sprejemajo vojaški način življenja, ki zahteva pogoste in dolgotrajne odsotnosti, vendar pa partnerji/-ke velikokrat občutijo pohlepnost vojaške organizacije, ki večino bremena skrbi za otroke in gospodinjstvo, posebej v času napotitve na MOM, prelaga nanje. Vojaške družine posebno med daljšo odsotnostjo pripadnika/-ce kot primarni vir podpore dojemajo socialno okolje, pri čemer se pokaže pomen razširjene družine. Hkrati pa izpostavljajo nekatere zaželene oblike institucionalne podpore, na primer sistem hitrega obveščanja o dogajanju v MOM. Pozitivno je bil ocenjen dostop do interneta, ki omogoča komunikacijo s partnerji/-kami in otroki. Kot kaže, prav to zmanjšuje stres in odtujenost ob odsotnosti enega od staršev.

Ključne Socialna podpora, institucionalna podpora, organizacijska podpora, vojaške besede družine, pohlepne institucije.

Abstract Coser defined military organization and family as two greedy institutions where competition for individuals' rank can lead to a conflict between work and family. However, various forms of support are available to provide for a successful coordination of these two. On the basis of the existing theories, the paper defines three types of support: social, institutional and organizational. Satisfaction with these three types of support has been examined in 33 Slovenian military families. In this respect, we also tried to determine the extent to which the Slovenian Armed Forces is perceived 
by military families as a greedy institution. The analysis of the interviews shows that Slovenian military families accept the military way of life, which requires frequent and lengthy absences. Partners, however, often experience the greedy nature of a military organization, which burdens them with a great deal of care for children and household, especially during deployments. Especially during prolonged absence of their members, military families perceive social environment as a primary source of support. In this context, the importance of the extended family comes to forefront. At the same time, they point to some of the desired forms of institutional support, such as Rapid Alert System reporting on the developments in international missions and operation. They have positively evaluated Internet access, which enables communication with partners and children. It seems that the latter reduces stress and alienation in the absence of one parent.

Key words Social support, institutional support, organizational support, military families, greedy institutions.

Uvod Plačano delo je pomemben del posameznikovega življenja, saj zagotavlja finančno in materialno neodvisnost, pomembno vpliva na posameznikovo samozavest ter posledično pripomore h kakovostnejšemu življenju. Za doseganje slednjega pa je pomembno usklajevanje časa in energije med plačanim delom in družino.

Že leta 1956 je Whyte (v Orthner, Bowen \& Beare, 1990) predstavil koncept intenzivne prepletenosti zasebnega življenja delavcev z njihovim plačanim delom, ki se $\mathrm{v}$ angleščini imenuje organization man. Pri tem konceptu, ki se je začel razvijati po industrijski revoluciji, gre za popolno predanost delavcev organizaciji, v kateri so zaposleni (Whyte, 1956). Leta 1989 sta Bowen in Orthner (1989) koncept razumevanja družine v podporni funkciji potreb organizacije poimenovala organization family. Sodobno delovno okolje od zaposlenih vedno bolj zahteva pripadnost in predanost, čemur so namenjene različne oblike tehnik krepitve delovnih skupin, fleksibilnost dela itn., kar pa zmanjšuje čas, ki ga posameznik lahko nameni družini oziroma zasebnemu življenju (Crompton, 2006). Pri tem Crompton (2006) posebej poudarja vlogo žensk, ki so zaradi tradicionalnega razumevanja svoje vloge večkrat prisiljene podrejati svoje plačano delo (oziroma kariero) plačanemu delu partnerja in prevzemati večji del neplačanega dela, ki izvira iz družinskega okolja (vzgoja otroka, skrb za gospodinjstvo, skrb za starejše družinske člane ipd.) (Kanjuo Mrčela, 2007, str. 13-22).

Usklajevanje obveznosti plačanega dela in pričakovanj družine je vse težje (Sachau in drugi, 2012, str. 63), zaradi česar raziskovalci po vsem svetu preučujejo odnos med obema. Družina je namreč ključnega pomena tako za posameznika kot za družbo in zato velik delež odnosov znotraj posameznikovega osebnega omrežja predstavljajo prav odnosi znotraj družine (Vuga in Juvan, 2011, str. 91). Zahteve družinskih članov in organizacije med seboj niso vedno usklajene, kar potencialno vodi v konflikt med obema (Heilmann in drugi, 2009, str. 86). 
V zadnjih 22 letih so bile družine pripadnikov in pripadnic Slovenske vojske (SV) preučevane predvsem skozi prizmo pripadnikov/-ic, redko pa so bile vključene v raziskavo na način, ko bi lahko izrazili svoja lastna stališča. Opravljena raziskava je lahko razumljena kot spodbuda za nadaljnje raziskovanje. Namen članka je analizirati, kako pripadniki SV in njihovi družinski člani usklajujejo pričakovanja družine in zahteve vojaške organizacije ter kakšno vrsto podpore imajo. Izhajajoč iz različnih konceptov podpore in oblik podpore, predpisanih z nacionalno zakonodajo, ter izhajajoč iz koncepta pohlepnih institucij smo sledili naslednjim ciljem: 1) preučiti percepcijo pohlepnosti vojaške organizacije med slovenskimi vojaškimi družinami; 2) ugotoviti, kakšne oblike podpore (organizacijska, institucionalna, socialna) vojaške družine že imajo, predvsem v času mednarodnih operacij in misij (MOM); 3) kolikšno je zadovoljstvo vojaških družin s posameznim tipom podpore.

\section{KONFLIKT MED DELOM IN DRUŽINO V POHLEPNIH INSTITUCIJAH}

Konflikt med delom in družino se lahko razvije v dve smeri, in sicer konflikt, ki je usmerjen z dela na družino ali konflikt z družine na delo. Pri prvem se zaradi delovnih obveznosti razvije razdor znotraj družinskega okolja, pri drugem pa se razvije razdor znotraj delovnega okolja zaradi zahtev družine (Sachau in drugi, 2012, str. 63). Tisti posamezniki, ki doživljajo več konfliktov med delom in družino, so manj zadovoljni z delom, življenjem, zakonsko zvezo ter družino (Heilmann in drugi, 2009, str. 86; Durand v Sachau in drugi, 2012, str. 63). Gledano z vidika družine pa lahko nerazrešeni problemi ovirajo opravljanje vsakdanjih družinskih obveznosti (Juvan in Jelušič, 2007, str. 555). Konflikt med delom in družino povzroči tudi pomanjkanje osebnih virov, kot sta na primer čas in energija. Poleg tega zahteve ene institucije največkrat onemogočajo zahteve druge ter posebna zahtevana vedenja ene institucije onemogočajo izpolnitev vloge v drugi (Heilmann in drugi, 2009, str. 87). Usklajevanje delovnih in družinskih obveznosti je torej že samo po sebi zahtevno, a posebnosti in zahteve delovnega okolja so tiste, ki to usklajevanje še bolj otežijo (Vuga in Juvan, 2011, str. 92).

Vojaška organizacija je moško naravnana in s poudarkom na učinkovitosti, hierarhiji, prevladi in nadzorovanju čustev ter moči. Te vrednote pa niso vedno združljive z vrednotami, zaželenimi v družini, zaradi česar je lahko vojaško življenje za družine že samo po sebi problematično (Juvan in Jelušič, 2007, str. 557). Dosedanje ugotovitve kažejo, da vojaška organizacija s svojimi zahtevami bolj pritiska na družino kot družina na vojaško organizacijo (Vuga in Juvan, 2011).

\section{POHLEPNE INSTITUCIJE}

Koncept pohlepnih institucij je podrobneje opredelil Lewis A. Coser (1974, str. 4), ki pravi, da pohlepna institucija od svojih pripadnikov zahteva popolno ter izključno zvestobo, pri čemer si želi podrediti tudi posameznikovo osebnost. Coser (1974) je opredelil srednjeveško družino in vojaško organizacijo kot pohlepni instituciji, 
medtem ko je sodobna družina pohlepna predvsem do žensk, torej žena in mater (Coser, 1974, str. 89-90). Podobno ugotavlja tudi Segal (1986), ki je pohlepnost obeh institucij preverjala na primeru oboroženih sil ZDA in ugotovila, da sodobna družina in vojaška organizacija še vedno precej ustrezata Coserjevi definiciji ter sta opredeljeni kot pohlepni instituciji. Obema institucijama je skupen koncept preživetja, ki izhaja iz zvestobe njunih članov (Soeters in drugi, 2003, str. 237). Treba pa je upoštevati, da se raven zahtev obeh institucij spreminja glede na situacijo in življenjske okoliščine. Družina je veliko zahtevnejša in bolj pohlepna do svojih članov, ko gre za mladoporočence, družine z majhnimi otroki ali družine z otroki s posebnimi potrebami (Coser, 1974; Segal, 1986), medtem ko vojaška organizacija postavlja do svojih članov višje zahteve $\mathrm{v}$ času dolgotrajnih terenskih usposabljanj ter napotitev na MOM (Juvan in Jelušič, 2007).

Pohlepna narava institucije se kaže tudi v tem, da je delovanje takšne institucije odvisno od popolne zvestobe njenih članov. Pohlepne institucije se od totalnih razlikujejo po načinu podrejanja, pri čemer pri prvih podreditev temelji na prostovoljni odločitvi in institucionalni pripadnosti, pri drugih pa na prisili. Vsaka institucija svojim pripadnikom nalaga določena pričakovanja in zahteve. Vojaška organizacija pa je v svojih zahtevah do svojih pripadnikov specifična, kar posredno vpliva tudi na družinske člane in osebno okolje pripadnika (Vuga in Juvan, 2011, str. 91; Blanchard, 2012, str. 84). Zahteve vojaške organizacije, ki jo kot delovno organizacijo ločujejo od drugih takšnih organizacij, so med drugim nereden delovni čas, nepredvidljivost delovnih nalog, dolgotrajna odsotnost, pogoste selitve (MacDermid Wadsworth in Southwell, 2011, str. 170; Vuga in Juvan, 2011, str. 91; Blanchard, 2012, str. 84). Pravzaprav je lahko to, kako močno določene zahteve prevladujejo v življenju družine, ključna razlika med vojaško organizacijo in drugimi organizacijami (Blanchard, 2012, str. 84).

Verjetno največja posebnost vojaške organizacije pa je koncept neomejene svobode, za katerega Martin in McClure (2000, str. 16) pravita, da od pripadnikov oboroženih sil v določeni situaciji zahteva pripravljenost na žrtvovanje svojega življenja. Takšna nevarnost, da je posameznik lahko ubit ali ranjen, pa ni navzoča le v vojnem stanju, ampak tudi na usposabljanju ali na vojaških vajah in pri opravljanju vsakdanjega dela (Juvan in Jelušič, 2007, str. 556). Segal trdi, da je s tem izražena najvišja stopnja pohlepnosti vojaške organizacije (Segal, 1986, str. 16).

Družina od svojih pripadnikov podobno kot vojaška organizacija pričakuje čas in zvestobo ter jim nalaga neke zahteve (Soeters in drugi, 2003, str. 237). Od družinskih članov se pričakuje, da so svoji družini čustveno predani in da izpolnjujejo svojo vlogo znotraj družine. Pričakuje se tudi identificiranje z družino in zadostno izražanje ljubezni (Vuga in Juvan, 2011, str. 91). Družina in vojaška organizacija kot dve med seboj konkurenčni pohlepni instituciji torej tekmujeta za čas, predanost, zvestobo, čustva, energijo itn. svojih članov, kar lahko vodi v konflikt med obema institucijama. 
Za zmanjšanje konflikta med plačanim delom in družino je zelo pomembna podpora. Pripadnik vojaške organizacije in njegova družina se zaradi značilnosti dela v vojaški organizaciji pogosto znajdeta v situacijah, v katerih potrebujeta pomoč in podporo. Na podlagi te teorije tipe podpore delimo na organizacijsko, institucionalno in socialno podporo.

\section{TIPOLOGIJA PODPORE}

\subsection{Organizacijska podpora}

V sklop organizacijske podpore prištevamo tiste elemente, ki izhajajo iz vojaške organizacije in so namenjeni pripadnikom SV. Mednje uvrščamo nekatere ugodnosti (na primer možnost dela na domu, fleksibilnost delovnega urnika), socialno in delovno zakonodajo ter določbe, ki kakor koli vplivajo na posameznega pripadnika SV. Z organizacijsko podporo so se ukvarjali številni avtorji (Eisenberger, 1986; Rhoades in Eisenberger, 2002; Lapiere in drugi, 2008), ki organizacijsko podporo oziroma zaznano organizacijsko podporo opredeljujejo kot splošno prepričanje zaposlenega, da delovna organizacija ceni njegov prispevek in skrbi za njegovo blagostanje. Organizacijska podpora praviloma vodi k boljšemu počutju, vzajemnemu zaupanju med organizacijo in pripadnikom, boljšim delovnim rezultatom, identifikaciji z organizacijo ter občutku dolgotrajne zaveze (Sachau in drugi, 2011, str. 65). Organizacijska zavezanost vojakov je večja, ko vojaška organizacija omogoča več podpore (Bourg in Segal, 1999, str. 648). Organizacijska podpora, ki je namenjena pripadnikom, je torej sestavljena iz uradne, zakonsko predpisane, podpore ter podpore nadrejenih in zaposlenih.

Za našo analizo smo širok pojem organizacijske podpore, kot so jo definirali nekateri zgoraj omenjeni avtorji, zožili. Pri tem smo kot organizacijsko podporo opredelili aktivnosti, ki jih SV izvaja zaradi zagotavljanja z zakonom določenih pravic (na primer pravica do skrajšanega delovnega časa do otrokovega tretjega leta starosti) in dodatnih ugodnosti, ki pozitivno vplivajo na učinkovitost zaposlenih (na primer fleksibilnost delovnega urnika). Organizacijska podpora je usmerjena na zaposlene v SV. Aktivnosti, ki so namenjene tako pripadnikom in pripadnicam kot tudi njihovim družinam in primarnemu socialnemu okolju, pa smo opredelili kot institucionalno podporo. V SV je zakonsko zagotovljena podpora, ki naj bi povečala motivacijo in učinkovitost pripadnikov, vsebovana v določilih Zakona o službi v SV. Zakon o službi v Slovenski vojski $(Z S S l o V)^{1}$ določa, da imajo pripadniki zaradi posebnih obremenitev in odgovornosti pri svojem delu pravico do celostne skrbi, ki je natančno določena v sedmem poglavju.

Iz sklopa celostne skrbi za pripadnike SV, ki je sicer precej obsežna, so za organizacijsko podporo pomembna predvsem določila o napredovanju, delu na domu, nadurah in drugih oblikah, ki obravnavajo fleksibilnost dela in zadovoljstva pripadnika na delovnem mestu. Tovrstna vzajemna podpora je poleg formalne celostne

l Zakon o službi v Slovenski vojski (ZSSloV). Ur. l. RS 68/2007 (30. julij 2007). 
skrbi SV izjemnega pomena za dobro počutje pripadnikov, izboljšanje njihove delovne učinkovitosti ter identifikacijo z vojaško organizacijo in posamezno enoto.

Delovni čas pripadnikov je opredeljen v 53. členu in je odvisen od vrste, namena, obsega in zahtevnosti njihovih nalog ter je lahko neenakomerno razporejen. Delo na domu skladno s 54. členom lahko traja največ tri ure na dan. Po ukazu so lahko pripadniki napoteni na izobraževanje in usposabljanje, daljše od enega leta.

$\mathrm{Na}$ pripadnike SV se seveda nanaša tudi Zakon o delovnih razmerjih (ZDR-1)2. Zakon o delovnih razmerjih $\mathrm{v}$ členih od 187. do 193. namreč določa posebne ugodnosti za starše otrok, mlajših od treh let oziroma do šestega leta starosti najmlajšega otroka, če gre za družino z več otroki. Tovrstno posebno varstvo staršem (ne glede na spol) omogoča koriščenje starševskega dopusta ter posebne ugodnosti glede nočnega in nadurnega dela. Varstvo omogoča, da starši otrok, ki so mlajši od treh let, nadurno ali nočno delo opravljajo le, če se z njim predhodno strinjajo, in sicer s pisnim soglasjem. Podobno določilo se nanaša tudi na starše samohranilce otrok s posebnimi potrebami ali bolnega otroka do sedmih let. V praksi tovrstno varstvo torej pomeni, da se staršem otrok, mlajših od treh let, ni treba udeležiti usposabljanj v tujini, MOM ali opravljati nadur, čeprav gre na primer za pomoč pri zaščiti in reševanju poplavnih območij.

\subsection{Institucionalna podpora}

V vojaški organizaciji so pripadniki/-ce socializirani v duhu »najprej služba, potem zasebno življenje« (Martin in McClure, 2000). Zahteve vojaške organizacije naj bi torej presegle tako zahteve družine kot osebne zahteve pripadnika. Institucionalna podpora izhaja iz organizacije in je namenjena pripadnikom ter njihovim družinam. Nekatere vojaške organizacije že prek institucionalnega okvira skrbijo tudi za celovito oskrbo vojaške družine. Ameriška vojska je na primer odgovorna za dobrobit in psihološko zdravje pripadnikov ter njihovih družin, razvoj in izobraževanje otrok, karierne ter izobraževalne možnosti za partnerje in za skrb za otroke (SOMF, 2011). Tudi SV omogoča tako oskrbo, ki pa se seveda od ameriške razlikuje, saj je SV precej manjša od ameriške in ji je namenjen tudi manjši del državnega proračuna. SV je v skrbi za vojaške družine vključena že v 11. členu ZSSloV, ki določa, da mora nadrejeni skrbeti za čim boljše pogoje za delo ter pomagati družinam podrejenih, če te to želijo.

Celostna skrb SV obsega zdravstveno, psihološko, religiozno, duhovno in socialnovarstveno oskrbo, pravno pomoč in svetovanje ter športne dejavnosti in organizirano preživljanje prostega časa. Zakon o službi v SV določa tudi nekatere pravice, ki pripadniku pripadajo tudi po prenehanju dela v SV. 76. člen Zakona o službi v SV predvideva, da se določila o celostni skrbi za pripadnike SV smiselno navezujejo tudi na njihove družinske člane. Za institucionalno oporo je pomemben predvsem 80 . člen, ki vsebuje določila o socialnovarstveni oskrbi, ki je sestavljena iz svetovanja in

2 Zakon o delovnih razmerjih (ZDR-1). Ur. l. RS 21/2013 (13. marec 2013). 
pomoči pri reševanju stanovanjskega problema, svetovanja in pomoči pri zagotavljanju otroškega varstva, svetovanja pri zaposlitvi zakonca ter iz pomoči pri selitvah, če so te posledica prerazporeditve znotraj vojaške organizacije. Pomoč pripadnikom in njihovi družini je predvsem finančne narave. Pomemben je tudi 85. člen istega zakona o klubih in centrih za celostno skrb, ki vsebuje določila o klubskih prostorih in dejavnostih, ki so namenjeni pripadnikom ter družinskim članom.

\subsection{Socialna podpora}

Zadnji tip opore je socialna opora, ki je namenjena tako pripadniku SV kot njegovi družini in izhaja iz pripadnikovega ali pripadničinega primarnega socialnega okolja. V raziskavah, izvedenih na Obramboslovnem raziskovalnem centru, v obdobju od 2003 do 2008, so kot primarno socialno okolje definirani partnerji/-ke, starši in prijatelji (Vuga in Juvan 2011, str. 89 in 102). Socialno oporo težko merimo, njene oblike pa se od družine do družine razlikujejo. V Sloveniji je socialna opora postala posebej pomembna po letu 2003, ko je bila uvedena poklicna vojska, s čimer je naraslo število t. i. vojaških družin.

Kogovšek in drugi (2003, str. 184) oblike socialne podpore uvrščajo v štiri večje skupine: materialna, informacijska, emocionalna in socialna podpora. Socialno podporo je treba opazovati tudi z vidika sorodstvenih vezi, saj del odnosov znotraj posameznikovega osebnega omrežja predstavljajo odnosi znotraj družine (Kogovšek in drugi, 2003, str. 185). Družina je še vedno ključnega pomena tako za posameznika kot za družbo. »Družina je osnovna institucija zasebnega življenja, kjer se oblikuje večina za ljudi pomembnih družbenih odnosov.« (Dremelj, 2003, str. 152)

Socialna opora je razdeljena na dva dela. Prvi del je sestavljen iz podpore, ki jo družina in prijatelji pripadniku/-ci namenijo, ko se ta odloči za vstop v organizacijo. Drugi del, ki je pravzaprav še bolj bistven, je sestavljen iz podpore, ki jo družina in prijatelji namenijo pripadnikom/-cam med njihovim delom, napotitvami v MOM ter med urjenji. Tu je ključna predvsem vloga ožje družine, saj družinsko življenje na opravljanje službe vpliva tako v mirnem kot vojnem času (Schneider in drugi v Juvan in Jelušič, 2007, str. 554). Družine so pomemben vir zadovoljstva pripadnikov vojaške organizacije (Schneider in drugi v Juvan in Jelušič, 2007, str. 564) in v Sloveniji predstavljajo pomembno vrednoto (Vuga in Juvan, 2011, str. 97), zato je nujno, da so družine del oskrbe, ki jo zagotavlja organizacija pripadniku.

Poleg ožje družine, ki skrbi za usklajevanje obveznosti in močno psihološko podporo, so pomembni tudi prijatelji in širša družina. Ti poleg podpore in spodbujanja pripadnika v njegovem prostem času skrbijo tudi za pomoč družini pripadnika, ko je ta odsoten. Zaradi številnih družinskih obveznosti so partnerji in partnerke med odsotnostjo pripadnika večkrat preobremenjeni z obveznostmi, ki jih težko usklajujejo z lastnimi službenimi obveznostmi, zato je pomoč širše družine in prijateljev toliko pomembnejša. Bistveno je, da partnerke ali partnerji ne dojemajo pripadnikov ali pripadnic kot breme družini, saj le tako lahko podpirajo njegovo delo. Juvan in Jelušič (2007, str. 562-3) sta ugotovili, da v SV ne prihaja do intenzivnih konfliktov 
med SV in družino, saj v povprečju pripadniki/-ce menijo, da so njihove družine zadovoljne z vojaškim življenjem. Štiri leta pozneje pa sta Vuga in Juvan (2011) ugotovili, da vendarle prihaja do nekaterih napetosti in pritiskov vojaške organizacije na družinsko življenje pripadnikov/-ic.

Zadovoljstvo družin omogoča lažje opravljanje obveznosti pripadnika in tudi lažje spoprijemanje vojaške družine s številnimi stresnimi dejavniki, kot so odsotnosti ali zdravstvene težave pripadnika.

\section{METODE IN VZOREC}

Raziskavo so izvedli študentje in študentke pri predmetu mirovne operacije (katedra za obramboslovje, Fakulteta za družbene vede, Univerza v Ljubljani), in sicer v lokalnem okolju, iz katerega prihajajo. V vzorec so bile tako zajete družine pripadnikov in pripadnic SV glede na lokalni izvor študentov in študentk. Raziskava temelji na strukturiranih intervjujih, ki so bili prilagojeni glede na okoliščine (partner/-ka, otroci, starši, bratje/sestre).

Opravljenih je bilo 33 intervjujev z družinami pripadnikov in pripadnic. Pripadniki/ice, katerih družinski člani so bili intervjuvani, so bili stari med 21 in 59 let ter so zasedali višje častniške ( 2 moška in 3 ženske), nižje častniške ( 5 moških in 2 ženski), podčastniške (3 moški in 1 ženska) čine ter 17 vojakov. Med pripadniki/-icami, katerih družinski člani so bili intervjuvani, je bila večina moških, in sicer 27 , ter 6 žensk, med njimi je bilo 14 poročenih, 8 v zunajzakonski skupnosti, 1 ločen in 10 samskih pripadnikov ter pripadnic. Intervjuvanih je bilo 20 partnerk in 1 partner, pripadnikov/-ic SV, 15 otrok in 20 staršev, od tega 12 mam in 8 očetov. Vsi pripadniki in pripadnice, katerih družinski člani so bili intervjuvani, so se udeležili najmanj ene MOM.

Intervju je bil sestavljen iz petih sklopov, in sicer vprašanja za pripadnika/-co, partnerja/-ko, otroke in starše, ter iz demografskega sklopa. Z vprašanji za pripadnike/-ce in partnerje/-ke smo preverjali: 1) občutek identifikacije z vojaško organizacijo in podpora partnerja/-ke; 2) težave z usklajevanjem plačanega dela in zasebnega življenja zaradi specifične narave dela v vojaški organizaciji; 3) poznavanje organizacijske in institucionalne podpore, ki ju nudi SV pripadnikom/-cam ter celotnim družinam; 4) usklajevanje plačanega dela in zasebnega življenja med opravljanjem nalog na MOM; 5) vir podpore družinam med opravljanjem nalog v MOM; 6) ponovna vzpostavitev odnosov v družini po vrnitvi z MOM. Sklop vprašanj za otroke je bil prilagojen njihovi starosti, obsegal pa je: 1) poznavanje poklica starša, ki je zaposlen v SV; 2) odnosi v družini med MOM in sprejemanje odsotnosti enega od staršev; 3) (vojaška vs. civilna) socialna mreža otrok; 4) odnos do poklica in službe starša, ki je zaposlen v SV. Sklop vprašanj za starše je obsegal te vsebine: 1) viri podpore staršem v času otrokove napotitve $v$ MOM; 2) odnos do otrokove napotitve v MOM. 


\section{RAZISKOVALNI VPRAŠANJ}

Teoretično izhodišče omenjenega članka je koncept pohlepnih institucij, kar predstavljata družina in vojaška organizacija, ter koncept usklajevanja med plačanim delom in zasebnim življenjem. Pri tem so posameznikom na voljo različne vrste podpore in v članku se osredotočamo na tri: socialno, institucionalno ter organizacijsko. Izhajajoč iz uvodoma opredeljenih ciljev, smo postavili raziskovalni vprašanji: 1) V kolikšni meri vojaške družine razumevajo SV kot pohlepno organizacijo, ki otežuje usklajevanje družine in plačanega dela; 2) Katera vrsta podpore je med vojaškimi družinami najbolj zaželena in katera najbolj izkoriščena.

\section{ANALIZA}

\subsection{Organizacijska podpora}

Nekaj več kot polovica partnerjev/-k pripadnikov SV meni, da narava vojaške organizacije od pripadnikov zahteva, da SV postavljajo na prvo mesto, torej pred družino. Prav tako je med partnerji/-kami pripadnikov deljeno mnenje, ko gre za vprašanje fleksibilnosti dela v vojaški organizaciji. Malo manj kot polovica partnerjev/-k meni, da vojaška organizacija pripadnikom omogoča dovolj dopusta, bolniške odsotnosti itn., medtem ko druga polovica vprašanih meni, da je partnerju/-ki zaposlenega/-e v SV težje uveljavljati na primer bolniško za varstvo bolnega otroka. Težavne so tudi pogoste odsotnosti zaradi dežurstev, kar je sicer bolj prisotno le v nekaterih enotah. Prav tako se kot ovira velikokrat pojavlja oddaljenost od delovnega mesta in s tem povezana vožnja, zaradi katere je pripadnik/-ca odsotna veliko več kot 8 ur. Pripadniki/-ce v takšnem primeru praktično ne sodelujejo pri organizaciji družinskega življenja in izvajanju obveznosti (nakupi, vožnja otrok v vrtec ali šolo, skrb za popoldanske dejavnosti otrok).

Višji častniki menijo, da SV enako obravnava tako matere kot očete z majhnimi otroki, vendar pa z zakonom predpisane ugodnosti pogosteje uveljavljajo ženske. Drugi intervjuvanci (podčastniki in vojaki) pa so izrazili občutek, da imajo ženske z majhnimi otroki več ugodnosti kot moški. Mnenje intervjuvanih pripadnic glede ugodnosti za starše z majhnimi otroki je deljeno, pri čemer je le približno polovica pripadnic zadovoljnih.

Na splošno pa prevladuje mnenje, da je SV pri zagotavljanju različnih ugodnosti močno omejena z zakonodajo in da bi morali biti izvzeti iz javnega sektorja.

Nekateri partnerji/-ke so izrazili nezadovoljstvo z zdravniško oskrbo svojega družinskega člana na MOM. Prav tako so izrazili nezadovoljstvo s prevozom vojakov v nekatere MOM in domov ter $\mathrm{z}$ organizacijo dopusta, pa tudi z obveščenostjo SV o položaju pripadnikov/-ic v MOM. Razlik pri odgovorih partnerjev/-ic častnikov/-ic, podčastnikov/-ic in vojakov ni mogoče opaziti. 
Med intervjuvanimi družinami prevladuje občutek, da od SV ne čutijo nobenega pritiska glede pravil vedenja zaradi partnerjeve-/kine (starševe, otrokove) zaposlitve v SV. Pripadniki/-ce sicer priznavajo, da obstajajo pravila, ki v nekaterih pogledih vplivajo na njihovo vedenje v prostem času, vendar zato ne čutijo večje obremenitve oziroma pritiska.

\subsection{Institucionalna podpora}

Družine so med seboj zelo razdeljene glede mnenj o institucionalni podpori, ki jim jo zagotavlja SV. Tretjina vprašanih meni, da SV omogoča dovolj institucionalne podpore pripadniku/-ci in njegovi družini. Ob tem pa je pomembna ugotovitev, da večina teh družin pomoči SV v času MOM ni potrebovala oziroma je ni uporabila. Preostali dve tretjini sta opozorili na pomanjkanje tovrstne podpore. Mnenje lahko povzamemo z izjavo pripadnika SV in njegove žene, ki trdita, da povabila na piknike, verske obrede in srečanja niso dovolj. Družinski člani pripadnika/-ce, ki se udeleži MOM, bi potrebovali predvsem tehnično pomoč, kot je na primer varstvo otrok, ali finančno pomoč, kot je na primer subvencioniran vrtec. Mnenja partnerjev/-k pripadnikov/-ic lahko povzamemo z mnenjem ene od partnerk:

»Pomoči SV sama nisem rabila, je pa ta pomoč vse prej kot zadovoljiva. Prave pomoči praktično ni. To, da se oglasijo takrat, ko smo vsi veseli, ne pomeni nič. Dobro bi bilo, da bi bil nekdo v času MOM članom družine (na primer ženi, $k i$ ostane sama) na voljo, če bi kaj potrebovala, tega pa ni. To bi bilo potrebno, da se vojak na MOM ne sekira in razmišlja, kako je doma.« (Intervju 32).

Največ informacij o MOM so družine pridobile od pripadnikov/-ic, nekaj manj iz medijev (internet, televizija), tisti, ki so se udeležili t. i. družinskega dneva, pa tudi tam. Najbolj so se zanesli na informacije, ki so jim jih posredovali pripadniki/-ce. Udeleženke družinskega dneva so dejale, da na tem srečanju zveš predvsem, kako pomembno je delovanje na določeni MOM.

Med intervjuvanimi družinami je bilo mogoče zaznati tudi nezadovoljstvo z obveščanjem družine o razmerah na MOM in o zdravstvenem stanju pripadnikov/-ic na MOM. Če pride do napada na bazo ali lokacijo v bližini baze, so družinski člani prestrašeni in zaskrbljeni, zato bi prav takrat bil potreben hiter in učinkovit sistem obveščanja SV.

Velika večina pripadnikov in pripadnic je prepričana, da so imeli z družinskimi člani dovolj stikov. Ti so jim bili omogočeni predvsem prek telefonskih linij in internetne povezave. Nezadovoljstvo s količino stikov so izpostavili nekateri pripadniki, ki so delovali na MOM UNIFIL Libanon ali zaključen NTM-I Irak. Eden izmed intervjuvanih je sicer izpostavil, kako se je podpora SV na tem področju skozi leta spreminjala:

»Moram reči, da so bili vzponi in padci. Na primer na začetku leta 1999 in 2000 je bilo omogočeno veliko zadev na misiji, potem se je pa zadeva začela zmanjševat do 
neke kritične točke, ki je bila 2005/06, potem se je pa začelo spet neke zadeve urejati in dodajati.« (Intervjuvanec 19).

Družine skupno ugotavljajo, da je bilo včasih manj stikov, njihova pogostost in kakovost pa se dvigata z vsako nadaljnjo MOM.

Le dve družini sta v okviru institucionalne podpore omenili službo za celostno skrb pripadnika, kar govori o slabi obveščenosti družin. Če partnerji potrebujejo pomoč, se prej obrnejo na starše in prijatelje. Nekaj partnerjev pozna sistem pomoči, ki pa se jim ne zdi primeren (pikniki družin, telefonske številke psihologov). Pravijo, da bi potrebovali nekaj bolj osebnega, kot na primer osebni pogovor, s čimer bi SV pokazala, da se zanima za družine pripadnikov/-ic, pa tudi več informacij o pripadnikih od SV, predvsem takrat, kadar so pripadniki na nevarnejših območjih. Zadovoljstvo s skrbjo SV za družine pa je bilo izraženo v Enoti za specialno delovanje, saj tako poveljnik kot tudi sodelavci vzdržujejo redne stike z družinami pripadnikov na MOM.

\subsection{Socialna podpora}

\subsubsection{Mnenje pripadnikov in pripadnic o socialni podpori v času MOM}

Pri vprašanju podpore družine se med vsemi intervjuvanci pojavlja enak vzorec. Velika večina pripadnikov poudarja, da se je o odhodu v MOM treba z družino temeljito pogovoriti. Vzorec je pokazal, da se pri starših in partnerjih/-kah pojavlja strah pred nevarnostjo MOM, da pa negativne posledice nemalokrat odtehta finančna stran. Če je pripadnik/-ca v MOM napoten/-a po ukazu, je nasprotovanje družinskih članov še toliko večje. Pripadniki/-ce, ki so s partnerko/-jem že več let, so v odgovorih navadno poudarili, da se o odhodu na misijo partnerja vedno odločata skupaj.

Otroci večine intervjuvancev so bili v času misije še zelo majhni, zato njihovega nasprotovanja niso občutili. Kritično obdobje za otroka je po mnenju intervjuvanih družin med tretjim in petim letom starosti. Intervjuvanci pa so enotnega mnenja, da je tako pri majhnih kot tudi pri tistih nekoliko starejših otrocih pomemben predvsem pogovor. Če je odsotnost pripadnika/-ce nekoliko daljša (na primer enoletna), se pri otrocih lahko pojavi bolj odklonilen odnos do naslednjih MOM in bolj zaščitniški ter posesiven odnos do enega od staršev.

Priprave pred odhodom pripadnika/-ce v krogu družine navadno potekajo $\mathrm{s}$ pogovorom. Velika večina pripadnikov je poudarila, da so svoje družinske člane na odhod pripravljali predvsem tako, da so jim pojasnili vse okoliščine, podrobnosti in potek dela na misiji. So pa moški pripadniki izpostavili, da je bilo družine treba pripraviti tudi v bolj tehničnem smislu. Partnerkam so na primer priskrbeli vse potrebne dokumentne in stike, jih naučili zamenjati avtomobilsko pnevmatiko, pripraviti kurjavo, če so na misijo odhajali v zimskih mesecih, itn. Pripadnice svojih partnerjev v tehničnem smislu niso pripravljale, vsaj tako lahko sklepamo iz njihovih odgovorov, se pa pojavi primer najema varuške med odsotnostjo pripadnice. 
Odnosi znotraj večine družin se, po besedah pripadnikov/-ic, niso spremenili. Dobršen del intervjuvanih pripadnikov meni, da se je njihov odnos s partnerko po vrnitvi še poglobil, predvsem se je povečalo medsebojno zaupanje, hkrati pa priznavajo, da je marsikdaj prihajalo tudi do konfliktov.

»V̌̌asih je prišlo do konfliktov zaradi odsotnosti, praznine, ker človeka nisi mogel videt vživo, ga objeti.« (Intervju 28).

Zaradi dolgotrajne odsotnosti pripadnikov/-ic pride tudi do ločitev, kar sicer ne moremo posplošiti na večino, vendar pa takšni primeri dokazujejo, da lahko daljša odsotnost enega izmed partnerjev negativno vpliva na zvezo.

Velika večina vprašanih pripadnikov/-ic se je pri vrnitvi z misije srečevala vsaj z manjšimi težavami pri ponovnem vzpostavljanju družinske dinamike. Nekateri so potrebovali le nekaj dni ali tednov, drugi celo več mesecev. Za oteženo privajanje na domače okolje sta kriva predvsem stres ob menjavi okolja in navajenost na drugačen način življenja. Mnenje enega izmed intervjuvancev:

"Velika težava je bil stres. Ko se enkrat vrneš z misije, nobena stvar ni več ista." (Intervju 28).

Velika razlika pri vrnitvi iz MOM se pokaže med spoloma. Ženske so namreč izpostavile, da jim v MOM ni bilo treba skrbeti za gospodinjska dela, kar je omogočalo popolno predanost plačanemu delu. Ponovno opravljanje gospodinjskih opravil so ob vrnitvi nazaj razumele kot veliko breme.

\subsubsection{Mnenje partnerjev/-k o socialni podpori med MOM}

Partnerji/-ke dojemajo odsotnost pripadnika/-ce zaradi napotitve v MOM kot del vojaške službe. Odsotnost sprejmejo, a to ne pomeni, da so partnerji/-ke zadovoljni/-e. Predvsem partnerke kot precejšnjo pomanjkljivost dolgotrajne odsotnosti občutijo odsotnost pri pomembnih dogodkih, kot so rojstni dnevi, maturantski plesi, prvi šolski dan, poroka otroka idr. Kot težja preizkušnja za partnerje/-ke pa je bila izpostavljena dolgotrajna odsotnost v obdobju, ko so otroci še majhni. Takrat se vsa odgovornost preloži na ramena tistega od staršev, ki ostane doma, kar je izrazila pripadnica SV, ki je hkrati tudi partnerka:

»Preden je šel, se je zdelo brezupno. V trenutku, ko so se na Brniku zaprla vrata za njim, je bilo vse enostavno, pa ne zato, ker bi pričakovala, da bo dejansko enostavno, sploh ne, ampak zaradi tega, ker si postavljen v situacijo in vě̌, da moraš to sprejeti. Stisneš zobe in gre. Jaz vedno pravim, da ni na misiji tisti, ki gre, ampakje na misiji tisti, ki ostane doma.« (Intervju 20).

Partnerke, ki so prav tako zaposlene v SV, sprejemajo poklic svojega moža in ga razumejo, saj, kot poudarijo, same vedo, kako vojska deluje. Tudi one se na odsotnost prilagodijo, vendar hkrati dodajajo, da se na življenje brez partnerja ne 
moreš popolnoma prilagoditi. Najmanj težav s prilagoditvijo dolgotrajnih odsotnosti je bilo zaznanih med pari, ki nimajo otrok.

Okolica se do družine, v kateri sta oče ali mama pripadnika SV, ne vede drugače. Partnerji/-ke pripadnikov opažajo, da širše okolje med napotitvijo v MOM izraža večji interes tako za počutje odsotnega pripadnika/-ce kot tudi za značilnosti MOM (podnebje, delovni pogoji, bivalne razmere, nevarnost itn.). Kadar je pripadnik/-ca odsoten/-a, partnerjem-/kam pomagajo in jih podpirajo predvsem njihovi starši ter nekoliko manj tudi starši odsotnega pripadnika/-ce. Intervjuji so pokazali, da so velikokrat v veliko pomoč prijatelji. Pomoč je potrebna predvsem pri varstvu otrok in fizičnih opravilih, pa tudi za psihično oporo ter spodbudo. V skupnostih brez otrok partnerji ne potrebujejo pomoči, vendar pravijo, da če bi jo potrebovali, bi jo verjetno tudi dobili. V dveh primerih pa družina kljub izraženi potrebi, pomoči od širšega socialnega okolja ni dobila.

Pripadnica, ki se je prav tako kot partner udeležila MOM, pravi, da je zelo pomemben časovni razmik med MOM in da je z napredovanji lažje usklajevanje družine in službe. Sama ima rada svojo službo, medtem ko partnerstvo, v katerem sta oba partnerja hkrati tudi pripadnika SV, vidi kot izziv.

\subsubsection{Mnenje otrok o socialni podpori v času MOM}

Iz raziskave je jasno razvidno, da otrokom primarno socialno podporo dajejo starši oziroma ožja družina. Otroci se po podporo največ obračajo k staršu, ki ostane z njimi. Mlajši otroci podporo iščejo le pri družini, medtem ko najstniki oporo najdejo tudi pri prijateljih, s katerimi se po odsotnosti starša več družijo. Skoraj vsi otroci imajo vsaj enega prijatelja, ki je v podobni situaciji in ima vsaj enega starša zaposlenega v SV. Le eden od vprašanih otrok je prijatelje, ki imajo starše, zaposlene v SV, spoznal prek organiziranih neformalnih srečanj SV. Od okolice pa ne pričakujejo podpore, saj večina niti ne želi razglašati, da je eden izmed staršev zaposlen v vojski, zato jih širša okolica ne obravnava nič drugače kot druge otroke.

Nekatere partnerke so pri mlajših, predšolskih otrocih opazile vedenjske spremembe, in sicer so otroci več jokali, se odtujili od odsotnega starša, niso vedeli, kako ravnati ob njegovi vrnitvi ipd. Partnerji/-ke so potožili, da bi jim pomoč partnerja prišla prav predvsem v času pubertete otrok. Ko so otroci starejši, vedenjskih sprememb zaradi odsotnosti enega od staršev ni opaziti. Partnerji/-ke so izpostavili pomembnost stikov s pripadnikom/-co, predvsem prek Skypa, in pogost pogovor o odsotnem staršu, s čimer je misel nanj kljub fizični odsotnosti v družini v resnici vedno prisotna.

\subsubsection{Mnenje staršev o socialni podpori v času MOM}

Starši pripadnikov SV, ki so odšli v MOM, prav tako kot preostali člani družine (partner/-ka, otroci) med odsotnostjo potrebujejo socialno oporo. Vsi vprašani imajo $\mathrm{v}$ bližini sorodnike in prijatelje, na katere se lahko obrnejo. Primarno podporo jim predstavljajo družinski člani, večinoma partner/-ka, ki ostane doma, in se vzajemno 
čustveno podpirajo med pripadnikovo/-čino odsotnostjo. Očetje so enoglasno odgovarjali, da socialne podpore niso potrebovali in si je niti ne želijo, medtem ko so matere podporo potrebovale in iskale pri bližnjih sorodnikih, prijateljih ter sosedih. Večini mater je veliko pomenilo že to, da je kdo povprašal o njihovem otroku, saj so potrebovale pogovor ter nekoga, s komer so lahko delile svoje skrbi. Za nekatere posameznice pa so bili pogovori in vprašanja okolice breme, saj so jih nenehno opominjali, da je njihov otrok v MOM.

Sklep Pogovori s slovenskimi vojaškimi družinami so pokazali, da je v Sloveniji prevladujoča oblika podpore socialna podpora. Že Godina $(1990 ; 2009)$ govori o tradiciji kolektivistične kulture (tudi Hofstede, 2001), ki je tradicionalno pretežno agrarnim družbam omogočala preživetje z močno povezanostjo družine in širšega socialnega okolja. Tudi slovenske vojaške družine se med odsotnostjo družinskega člana največkrat po pomoč obrnejo na primarno socialno okolje, medtem ko je institucionalna opora šele druga izbira. Slednje bi si sicer želeli več, vendar je na podlagi odgovorov težko oblikovati enotno mnenje glede njene oblike. Intervjuvane družine so izrazile željo po pomoči pri varstvu otrok, psihološki pomoči oziroma potrebo po pogovoru, tehnični pomoči, predvsem pa so poudarili potrebo po boljši obveščenosti o tem, kaj se dogaja v MOM.

Opažamo razdvojenost pripadnikov/-ic in njihovih družin, ki bi si po eni strani želele več pozornosti SV med trajanjem MOM, in priznanje, da so družine med odsotnostjo v težkem položaju, vendar pa hkrati ne želijo dopustiti, da se SV preveč vpleta v njihovo zasebno življenje. Treba bi bilo torej najti pravo razmerje med pomočjo vojaške organizacije in vdorom v zasebnost pripadnikov/-ic ter njihovih družin. ${ }^{3}$ Se pa kot zelo pomemben segment institucionalne podpore kaže obveščanje družin v času napotitve na MOM. Posebno takrat, kadar je pripadnik/-ica dlje časa nedosegljiv/-a prek elektronskih medijev (Skype, Facebook ipd.) ali prek telefona, so družinski člani zaskrbljeni. Slednje se intenzivira v primeru medijskega poročanja o napadu na ožjem območju (v bližini baze) delovanja pripadnikov/-ic. Dobro bi bilo vzpostaviti sistem hitrega obveščanja družinskih članov, prek katerega bi SV lahko reagirala $\mathrm{v}$ omenjenih situacijah.

Domala soglasno je bilo izraženo zadovoljstvo z zagotavljanjem dostopa do interneta v MOM ter posledično omogočanje pogostih stikov z družinskimi člani. To se je kot posebnega pomena pokazalo predvsem $\mathrm{v}$ družinah $\mathrm{z}$ majhnimi otroki, saj pogosti pogovori z odsotnim staršem, pri čemer ga lahko tudi vidijo, praviloma olajšajo težave, ki nastopijo ob dolgotrajni odsotnosti (jok, odtujenost, trma idr.).

Stališča o organizacijski podpori so v vojaških družinah deljena. Del družin je zadovoljen, medtem ko približno polovica izraža določeno stopnjo nezadovoljstva s fleksibilnostjo delovnega časa partnerja/-ke, zaposlenega/-e v SV (na primer bolniška odsotnost med otrokovo boleznijo), ki naj bi bila manjša kot pri partnerju/-ki, ki

3 Kot primer dobre prakse se pokaže Enota za specialno delovanje, SV. 
ni zaposlen/-a v SV. To kaže, da pomemben del vojaških družin ne zaznava večjih sprememb v organizacijski podpori v zadnjih sedmih letih, saj sta podobno ugotovili že Černič Istenič in Kneževič Hočevar (2006). Avtorici ugotavljata, da imajo pripadniki/-ce SV manj možnosti za dogovarjanje o premakljivem delovnem času, o koriščenju dopusta ali možnosti zamenjave delovnega mesta zaradi potreb družine (Černič Istenič in Kneževič Hočevar, 2006, str. 233). Tako se kot ena izmed težav pri usklajevanju zasebnega življenja in plačanega dela v nekaterih primerih izpostavlja oddaljenost delovnega mesta, kar pripadniku/-ci domala onemogoča aktivno sodelovanje v družinskem življenju skozi delovni teden (vožnja otrok na obšolske aktivnosti, v vrtec, nakupi idr.).

Za zdaj glavni vir opore pripadnikom/-cam SV ostaja partner/-ka, slednjim pa širša družina. Če govorimo, da slovenska družba postaja vedno bolj individualizirana ter so družine vedno bolj nuklearnega tipa, se ob dolgotrajni odsotnosti v MOM praviloma kot koristnejši izkaže razširjeni tip družine, z vsemi sorodniki in morda tudi prijatelji. Močno podporo partnerjev/-k pripadnikov/-ic SV lahko delno interpretiramo tudi v kontekstu ugotovitev Černič Istenič in Kneževič Hočevar (2006), ki izpostavljata močno povezanost med delovnim in družinskim okoljem v vojaški organizaciji in pomembno vlogo partnerja/-ke v življenju vojaka.

Partnerja se večinoma strinjata, da je udeležba v MOM pozitivno vplivala na njun odnos. Zveze so po njihovih besedah postale bolj trdne, povečalo se je medsebojno zaupanje. Hkrati med partnerkami prevladuje mnenje, da je udeležba v MOM vplivala na pripadnikovo osebnost. Večina partnerk je opazila pozitivne spremembe; pripadniki naj bi postali bolj odgovorni, čuteči, prilagodljivi in zrelejši. Analiza je pokazala na nekatere razlike med spoloma, in sicer pri ponovnem prevzemanju vloge v družini po vrnitvi iz MOM. Ženske so soglasno poudarile, da jim je ponovna delitev časa in energije med plačano delo ter gospodinjska opravila pomenila veliko težavo. To nakazuje, da so tudi pripadnice vojaške organizacije še vedno glavne nosilke gospodinjstva in so tako veliko bolj izpostavljene zahtevam dveh pohlepnih institucij kot moški kolegi. Slednja ugotovitev pojasnjuje, zakaj so dosedanje raziskave pokazale zelo nizko stopnjo pohlepnosti SV in konflikta med družino in vojsko med anketiranci so bili večinoma moški.

Glede na uvodoma zastavljene cilje in raziskovalni vprašanji lahko ugotovimo, da kljub visoki stopnji podpore vojaškemu načinu življenja med partnerji/-kami pripadnikov/-ic SV, partnerji/-ke vendarle občutijo pohlepnost vojaške organizacije, ki jo dojemajo kot postavljanje službe pred družino. To občutijo predvsem, ko je treba poskrbeti za bolne otroke, pri fleksibilnosti koriščenja dopusta ali bolniške odsotnosti ipd. Ugotavljamo, da družine največ koristijo socialno podporo, pri čemer pa si vsaj polovica vprašanih želi tudi več institucionalne podpore, ki naj bi potekala v teh oblikah: 1) obveščanje družin o stanju v MOM; 2) osebni stiki (pogovori) z družinami; 3) tehnična pomoč; 4) pomoč pri varstvu otrok. 
Kakovostna in učinkovita organizacijska, institucionalna in socialna opora zagotavljajo primerno podporo pripadniku/-ci ter njegovi/njeni družini, kar omogoča učinkovito in varno opravljanje službenih obveznosti. Uravnotežena kombinacija vseh treh podpor pa se kaže v zadovoljstvu pripadnikov/-ic in njihovih družin.

\section{Literatura}

1. Blanchard, E. Samantha, 2012. Are the Needs of Single Parents Serving in the Air Force Being Met? Advances in Social Work 13-1, str. 83-97.

2. Bowen, G. L. in Orthner, D. K., 1989. The Organization Family: Work and Family Linkages in the US Military. New York: Praeger Publishing.

3. Coser, A. Lewis, 1974. Greedy Institutions: Patterns Of Undivided Commitment. New York: Free Press.

4. Crompton, Rosemary, 2006. Employment and the Family: The Reconfiguration of Work and Family Life in Contemporary Societies. Cambridge: Cambridge University Press.

5. Černič Istenič, M. in Kneževič Hočevar, D, 2006. Usklajevanja dela in družine v Slovenski vojski. Sodobni vojaški izziv. 4, str. 215-236.

6. Eisenberger, R., Huntington R., Hutchison S., Sowa, D., 1986. Perceived organizational support. J Appl Psychol. 71, str. 500-507.

7. Dremelj, P., 2003. Sorodstvene vezi kot vir socialne opore posameznikov. Družboslovne razprave. 43, str. $149-170$.

8. Godina Vuk, V., 1990. Vpliv kulturnih vzorcev in tradicije na procese družbenega razvoja. Družboslovne razprave. 7-10, str. 179-86. http://www.druzboslovnerazprave.org/medial pdf/clanki/dr10Godina.PDF, 15. 6. 2011.

9. Godina Vuk, V., 2009. Intervju. Mladina. 5, 10. 7. 2009.

10. Heilmann, G. Sharon, Bell, John E., McDonald, Gavin K.. 2009. Work--Home Conflict : A Study of the Effects of Role Conflict on Military Officer Turnover Intention. Journal of Leadership \& Organizational Studies. 16-1, str. 85-96.

11. Hofstede, Geert, 2001. Culture's Consequences: Comparing Values, Behaviors, Institutions and Organizations across Nations. London in New Delhi: Sage Publications.

12. Intervju 19: Intervju z družino pripadnika/ce Slovenske vojske. Opravljen oktobral novembra 2012.

13. Intervju 20: Intervju z družino pripadnika/ce Slovenske vojske. Opravljen oktobral novembra 2012.

14. Intervju 28: Intervju z družino pripadnika/ce Slovenske vojske. Opravljen oktobral novembra 2012.

15. Intervju 32: Intervju z družino pripadnika/ce Slovenske vojske. Opravljen oktobral novembra 2012.

16. Juvan, J. in Jelušič, L., 2007. Vojaške družine na stičišču zahtev med družino in vojaško organizacijo. Teorija in praksa. 44-5, str. 551-67.

17. Kanjuo Mrčela, A., 2007. Uvod: Plačano delo in ostalo. V Kanjuo Mrčela A., Černigoj Sadar N., (ur.) Delo in družina - s partnerstvom do družini prijaznega delovnega okolja. Ljubljana, FDV, 2007, str. 11-22.

18. Kogovšek, T., Hlebec, V., Dremelj, P. in Ferligoj, A., 2003. Omrežja socialne opore Ljubljančanov. Družboslovne razprave. 43, str. 183-204.

19. Lapierre, L. M., Spector, P. E., Allen, T.D , Poelmans, S., Cooper, C.L., O'Driscoll, M. P. in ostali, 2008. Family-supportive organization perceptions, multiple dimensions of workfamily conflict, and employee satisfaction: A test of a model across five samples. Preprint online. 
20. MacDermid Wadsworth in Shelley Southwell, Kenona, 2011. Families: Extreme Work and Extreme "Work-Family". The ANNALS of the American Academy of Political and Social Science. 638, str. 163-183.

21. Martin, A. James in McClure, Peggy, 2000. Today's Active Duty Military Family: The Evolving Challenges of Military Family Life. V J. A. Martin, L. N. Rosen in L. R. Sparacino, ur. The Military Family: A Practice Guidef or Human Service Providers. Preager Publishers, 2000, str. 3-25.

22. Moelker, Rene in Van der Kloet, Irene, 2003. Military Families and the Armed Forces: A Two-Sided Affair? V G. Caforio, ur. Handbook Of The Sociology Of The Military. New York: Springer, 2003, str. 201-223.

23. Orthner, D. K., Bowen, G. L., Varga, G. B., 1990. The Organization Family: A Question of Work and Family Boundaries. Marriage \& Family Review. 15-3, str. 15-36.

24. Rhoades L., Eisenberger, R., 2002. Perceived organizational support: a review of the literature. J Appl Psychol. 87, str. 698-714.

25. Sachau, Daniel A., Gertz, Jessica, Matsch, Mahlia, Johnson Palmer, Ashley, Englert, David, 2012. Work-Life Conflict and Organizational Support in a Military Law Enforcement Agency. Journal of Police and Criminal Psychology. 27-1, str. 63-72.

26. Segal, Mady W, 1986. The Military and The Family as Greedy Institutions. Armed Forces and Society. 13-1, str. 9-38.

27. Soeters, L. Joseph, Winslow, J. Donna in Weibull, Alise, 2003. Military Culture. V G. Caforio, ur. Handbook of the Sociology of the Military. New York: Springer, 2003, str. 237-249.

28. SOMF - Strenghtening Our Military Families, 2011. Meeting America's Commitment. Washington: White House.

29. Vuga, J., Juvan, J., 2011. Vloga posameznikovega primarnega socialnega okolja v odnosu do vojaške organizacije: primer Slovenske vojske. Družboslovne razprave. 66-5, str. 89-109.

30. Whyte, E. H., 1956. The Organization Man. New York: Simon and Schuster.

31. Zakon o delovnih razmerjih (ZDR-1). Ur. l. RS 21/2013 (13. 3. 2013). http://www.uradnilist.si/1/content?id=112301, 27. 4. 2013).

32. Zakon o službi v Slovenski vojski (ZSSloV). Ur. l. RS 68/2007 (30. 7. 2007).http://www. uradni-list.si/1/objava.jsp? urlid=200768\&stevilka=3761, 27. 4. 2013. 



\section{SINDROM ZALIVSKE VOJNE}

\section{GULF WAR SYNDROME}

Povzetek Zdravstvene težave, ki se pojavljajo pri veteranih različnih vojn, pogosto poljudno poimenujemo kar vojni sindromi. Najbolj znan je tako imenovani vietnamski sindrom, za katerega so predvsem značilni znaki posttravmatske stresne motnje. Vsaka vojna na udeležencih ne pusti povsem enakih prevladujočih posledic. Za veterane zalivske vojne leta 1990 in 1991 v Iraku in Kuvajtu so značilni različni znaki in simptomi, kot so utrujenost, vročina, mišični revmatizem, slabost, kratkotrajnost spomina, zmedenost, kožni izpuščaji, driska, kronični bronhitis, depresija in drugi. Množico različnih simptomov, ki so se začeli postopno pojavljati pri vojakih po koncu služenja v Perzijskem zalivu, imenujemo sindrom zalivske vojne. Med njegove možne vzroke prištevamo kemično orožje, ostanke streliva z osiromašenim uranom, stranske učinke cepljenja vojakov proti antraksu in nalezljive bolezni (paraziti).

Ključne Zalivska vojna, sindrom zalivske vojne, bolezni, vojni veterani.

besede

Abstract Health problems identified with the veterans of various wars are often referred to as war syndromes. Vietnam syndrome is probably the most famous one. It is mainly characterized by the signs of post-traumatic stress disorder. However, the prevailed consequences of wars are not always equal. Veterans of the 1990 and 1991 Gulf War in Iraq and Kuwait suffer from the signs and symptoms such as fatigue, fever, muscular rheumatism, nausea, weak memory, confusion, rashes, diarrhoea, chronic bronchitis, depression, and others. The set of symptoms which gradually emerged with the veterans after the Gulf War is called the Gulf War Syndrome. Possible causes for its emergence include chemical weapons, remains of depleted-uranium ammunition, side effects of anthrax vaccines and contagious diseases (parasites). 
Uvod Na začetku avgusta 1990 je Irak izvedel vojaško invazijo na Kuvajt. Ozadje konflikta sega vse v trideseta leta prejšnjega stoletja, ko so nacionalisti v Iraku trdili, da mora biti Kuvajt del Iraka. Povod za invazijo je bilo nesoglasje med Irakom in Kuvajtom glede črpanja nafte ter zavrnjenega plačila za presežene kvote, ki jih je Irak očital Kuvajtu. Že prvi dan invazije, 2. avgusta, so iraške sile dosegle glavno mesto, tretji dan pa so bile kuvajtske sile poražene. Po vrsti resolucij Varnostnega sveta Združenih narodov so Združene države Amerike (ZDA) zaradi strateških interesov s podporo več kot 30 držav januarja 1991 sprožile zračno operacijo Puščavski vihar (Desert Storm), februarja pa še kopensko operacijo Puščavska sablja (Desert Sabre). Irak je 26. februarja 1991 najavil umik svojih sil iz Kuvajta (UCDP Conflict Encyclopedia).

Izraz zalivska vojna v tem prispevku se nanaša na invazijo Iraka na Kuvajt leta 1990 in obe omenjeni operaciji ZDA in njenih zaveznikov leta 1991 kot odgovor na invazijo. V mednarodni koaliciji proti Iraku je sodelovalo skupno 750.000 vojakov različnih narodnosti (Slatenšek, 2002). Silovitim zračnim napadom zavezniških sil je sledila obsežna kopenska ofenziva. Pripadniki zavezniških sil na eni strani, iraški vojaki na drugi in civilno prebivalstvo so bili izpostavljeni različnim dejavnikom tveganja, ki so se pokazali v obliki poslabšanja njihovega zdravstvenega stanja, različnih obolenj in drugih zdravstvenih težav. Njihove težave so se pokazale že med vojno, najbolj očitno pa nekaj let po njej. V prispevku ${ }^{1}$ so predstavljene različne raziskave ameriških in britanskih znanstvenikov, ki so proučevali najrazličnejše dejavnike tveganja za pojav bolezenskih simptomov.

Termin sindrom zalivske vojne se nanaša na množico različnih simptomov, ki so se začeli postopno pojavljati pri vojakih po koncu služenja v Perzijskem zalivu. Govorimo o množici kroničnih znakov in simptomov, o katerih so poročali vojaki koalicije držav, ki je delovala v operacijah leta 1991. Okoli 100.000 oziroma 16 odstotkov ameriških veteranov zalivske vojne se je od 6 do 18 mesecev po vojni postopoma začelo soočati z različnimi znaki in simptomi, kot so utrujenost, vročina, mišični revmatizem, slabost, kratkotrajnost spomina, zmedenost, kožni izpuščaji, driska, kronični bronhitis, depresija in drugi (Gulf War Syndrome Research).

Sindrom zalivske vojne ni edini izraz, ki se je uveljavil za opis posledic nekega vojaškega spopada. Za pojav značilnih simptomov (utrujenost, glavobol, zbeganost, težavna koncentracija, pozabljivost, nočne more) pri vojakih v prvi svetovni vojni se je uporabljal tudi pojem Da Costov sindrom² (Hyams, Wignall, Roswell, 1996). Za dolgoročne posledice izpostavljenosti ekstremnemu stresu se je v pogovornem jeziku uveljavil pojem vojnega sindroma, še pogosteje pa govorimo kar o tako imenovanem vietnamskem sindromu (najbolj znan zaradi množičnosti pojava, pa tudi javnosti problematike). Tudi med vojnami in še pogosteje po njih se je na območju nekdanje Jugoslavije v 90. letih prejšnjega stoletja veliko govorilo o »vietnamskem«

\footnotetext{
Prispevek je pripravljen pretežno na podlagi diplomskega dela Mateje Kopač z naslovom Sindrom zalivske vojne (1990-1991). Delo je nastalo leta 2012 na Fakulteti za družbene vede Univerze v Ljubljani pod (so) mentorstvom dr. Jelene Juvan in dr. Maje Garb.

2 Da Costa je med ameriško državljansko vojno opravil eno prvih študij vojnega sindroma. Odkril je 300 vojakov z značilnimi simptomi in te simptome poimenoval »razdražljivo srce» (Hyams, Wignall, Roswell, 1996).
} 
sindromu (na primer »vietnamski sindrom na hrvaški način« - glej Globus 1998). Čeprav vsi ti sindromi spadajo med tako imenovane sindrome oziroma bolezni vojnih veteranov, ni nujno, da imajo veliko skupnega. Medtem ko vietnamski sindrom označuje psihične posledice, zlasti še pojav posttravmatske stresne motnje pri vojakih, ki so sodelovali v vojni v Vietnamu v 60. in 70. letih prejšnjega stoletja ${ }^{3}$, podobno velja tudi za »hrvaški sindrom«, pa so za sindrom zalivske vojne bolj značilne fizične zdravstvene posledice sodelovanja v operacijah v Iraku. Za predstavitev sindroma zalivske vojne v obliki prispevka smo se odločile zato, da ta sindrom razmejimo od drugih vojnih sindromov in da opozorimo na stranske učinke uporabe vojaške opreme in orožja ter celo zaščitnih ukrepov za vojake.

\section{PRISOTNOST SIMPTOMOV}

Sindrom zalivske vojne spada med bolezni in nebojne poškodbe. Vse do 20. stoletja je bila za vojaka, ki je sodeloval v vojni, precej večja verjetnost, da bo umrl zaradi bolezni, kot da bo umrl zaradi nasprotnikovega ognja. Delež smrti zaradi bolezni v primerjavi s smrtnimi žrtvami je bil skoraj $3: 1$, predvsem zaradi slabih higienskih razmer in pustošenja epidemičnih bolezni. V prvi zalivski vojni je bilo 13 odstotkov smrti zaradi bolezni in 87 odstotkov smrti zaradi drugih vzrokov. Skupaj je bilo nebojnih smrti 145, bojnih smrti pa 148. Razmerje je bilo približno 1 : 1 . Prva zalivska vojna je bila znana kot ena najbolj »strupenih vojn« v zgodovini, če gledamo z vidika posledic (Clodfelter, 2002, str. 6).

Sindrom zalivske vojne se sprva ni obravnaval kot bolezen, temveč kot kronična utrujenost. Pojavljale so se težave pri definiranju termina, saj je bilo veliko vzrokov; navadno so združili več različnih opredelitev v eno. Inkubacijska doba pacientov od nekaj mesecev do nekaj let se je razlikovala glede na izpostavljenost vojakov v vojni (Slovenska tiskovna agencija, 2008). Čeprav je bilo žrtev med ameriškimi vojaki malo, pa so bili ti izpostavljeni različnim stresorjem. Nanašajo se na množico bioloških in kemičnih povzročiteljev, vključno z zemljo, dimom iz naftnih požarov, z barvami, raztopili, insekticidi, naftnimi plini in gorenjem različnih stvari, živčnimi organofosfati, osiromašenim uranom, cepljenjem proti antraksu in nalezljivim boleznim. Veliko vojakov se je vrnilo domov in počelo normalne aktivnosti. Nekateri pa so čez čas zaskrbljeno začeli poročati o zdravstvenih težavah, ki naj bi bile povezane z vojaško operacijo v Perzijskem zalivu.

Začetna poročila so razlagala sindrom zalivske vojne kot posledico vojnega stresa. Pozneje se je pokazalo, da vojni stres, travme in psihiatrične diagnoze kot na primer posttravmatska stresna motnja (PTSD) niso vzrok. Vojna je bila kratka, število smrtnih žrtev je bilo razmeroma majhno in večina veteranov med služenjem ni bila priča smrtim. Opredeliti odnos med medicinsko in psihiatrično boleznijo glede določitve simptomov je bilo zapleteno, saj imajo lahko utrujenost, kognitivne težave

\footnotetext{
Za vojno $v$ Vietnamu je značilna nizka stopnja psihičnih težav (na primer akutne reakcije na stres) pri borcih med vojno, medtem ko se posttravmatska stresna motnja pri vietnamskih veteranih množično pojavlja (povzeto po Gabriel, 1991, str. 71).
} 
in depresija tako fizične (glavobol, posledica izpostavljenosti strupenim snovem) kot psihične vzroke (travmatične izkušnje, stres ali kronična bolezen). Zaradi različnih obravnavanj sindroma zalivske vojne se pojavljajo različne ugotovitve in razprave o ustreznosti ene in druge razlage. V zgodnjih študijah so ugotovili, da je pri veteranih prve zalivske vojne višja stopnja pojavnosti neznanih simptomov kot pri vojakih, ki niso služili v Perzijskem zalivu. Koliko vojakov prve zalivske vojne je v resnici imelo zdravstvene težave? Maja 2004 je bilo ocenjeno, da je imelo zdravstvene težave 14 odstotkov veteranov te vojne. Več kot 179.000 ali 30 odstotkov veteranov je bilo spoznanih kot nesposobnih za služenje v vojski. Vlada in mediji so poročali o okoli 100.000 pa do 700.000 ameriških veteranih (Research Advisory Committee on Gulf War Veterans' Illnesses, 2004).

Epidemiološke raziskave za proučevanje zdravja in bolezni v populaciji so pokazale na nerazložljive zdravstvene težave. Raziskave so bile opravljene z veterani iz različnih rodov oboroženih sil, z veterani iz različnih držav in veterani, ki so služili na različnih območjih bojišča. V raziskavi so opredeljeni simptomi, ki so se pokazali pri veteranih zalivske vojne. Te simptome so nato preverili pri veteranih drugih vojn. Podatki prisotnosti simptomov pri obeh skupinah veteranov so prikazani v tabeli.

\begin{tabular}{|c|c|c|c|}
\hline \multirow{16}{*}{$\begin{array}{r}\text { Tabela: } \\
\text { Primerjava } \\
\text { prisotnosti } \\
\text { simptomov }\end{array}$} & Simptomi & $\begin{array}{c}\text { Veterani prve } \\
\text { zalivske vojne (v \%) }\end{array}$ & $\begin{array}{l}\text { Drugi veterani } \\
\qquad(\mathrm{v} \%)\end{array}$ \\
\hline & glavobol & 54 & 37 \\
\hline & bolečine v sklepih & 45 & 27 \\
\hline & utrujenost & 38 & 15 \\
\hline & depresija & 36 & 22 \\
\hline & težave s koncentracijo & 35 & 13 \\
\hline & bolečine v mišicah & 33 & 17 \\
\hline & driska & 31 & 15 \\
\hline & kožni izpuščaji & 29 & 13 \\
\hline & kašljanje & 24 & 14 \\
\hline & plitko dihanje & 24 & 11 \\
\hline & izguba las & 23 & 12 \\
\hline & bolečine $v$ trebuhu & 23 & 12 \\
\hline & vrtoglavica & 22 & 10 \\
\hline & težave z govorjenjem & 10 & 3 \\
\hline & težave z ejakulacijo & 7 & 1 \\
\hline
\end{tabular}

Vir: Research Advisory Committee on Gulf War Veteran's Illnesses, 2004. 
Kot je razvidno iz tabele, so med veterani prve zalivske vojne in drugimi veterani očitne razlike, saj imajo drugi veterani nižjo stopnjo pojavnosti vseh navedenih simptomov. Pri raziskavi je pomembno upoštevati tudi dejstvo, da se navadno ne pojavi le en simptom, temveč se jih pojavi več skupaj. Na primer kombinacija glavobola, bolečin v sklepih in driske ob istem času. Naslednja primerjava se nanaša na vprašanje, koliko simptomov so vojaki občutili in prepoznali ob pojavu sindroma. Več kot 30 odstotkov vojakov prve zalivske vojne je imelo od 3 do 6 simptomov in okoli 5 odstotkov drugih vojakov je imelo od 3 do 6 znakov sindroma zalivske vojne. Pri pojavu enega ali dveh znakov je bilo stanje približno enako - okoli 30 odstotkov vojakov prve zalivske vojne in drugih vojakov. Dokler so bili obravnavani posamezni simptomi, ni bilo mogoče najti jasne povezave s služenjem v prvi zalivski vojni. Razlika se pokaže pri opredelitvi več kot treh simptomov hkrati, pri čemer imajo veterani prve zalivske vojne višji odstotek. Pri proučevanju je treba upoštevati pogostost simptomov, njihovo trajanje in pojav več simptomov hkrati (Research Advisory Committee on Gulf War Veteran's Illnesses, 2004).

Pojav sindroma je bil najnižji med veterani, ki so služili na krovu ladij (21\%), nato med veterani, ki so služili na kopnem kot podpora (31 \%), in najvišji med veterani, ki so sodelovali v zračnih napadih (42 \%). Pojav bolezni se razlikuje tudi glede na čas. Tisti, ki so prišli pred začetkom prve zalivske vojne, januarja leta 1990, so imeli malo znakov (9\%), najvišja raven je bila med tistimi, ki so ostali na območju do konca vojne (43\%). Dejavnika časa in lokacije kažeta na to, da je sindrom zalivske vojne povezan s posebnimi značilnostmi v času vojaške napotitve, zato ju ni mogoče spregledati (Research Advisory Committee on Gulf War Veteran's Illnesses, 2004).

\section{MOŽNI VZROKI SINDROMA ZALIVSKE VOJNE}

Raziskovalno-svetovalni komite za proučevanje sindroma zalivske vojne iz ZDA (Research Advisory Committee on Gulf War Veterans' Illnesses) je proučeval korelacijo med sindromom in temi možnimi vzroki:

- kemična orožja,

- ostanki streliva z osiromašenim uranom,

- stranski učinki cepljenja vojakov proti antraksu,

- nalezljive bolezni (paraziti).

\section{Kemično orožje}

Vojni veterani so bili med prvo zalivsko vojno izpostavljeni kemičnemu, radiološkemu in biološkemu orožju. Kemična vojna je povzročila uničenje skladišč in tovarn kemičnega orožja ter izpostavljenost plinom. Kljub majhni izpostavljenosti toksičnim kemikalijam in organosfatom, živčnim plinom in pesticidom so vojaki trpeli za kroničnimi boleznimi. Po tem, ko je bilo razstreljeno skladišče v Khamisiyahu leta 1991, je bilo živčnemu plinu izpostavljenih več kot 125.000 ameriških in 9000 britanskih vojakov (Research Advisory Committee on Gulf War Veterans' Illnesses, 2004). 
Avtorji nekaterih študij pojmujejo sindrom zalivske vojne kot posledico izpostavljenosti aflatoksinom in jemanja tablet za zaščito pred iraškim kemičnim orožjem na bazi acetilholinskih receptorjev. Oboje negativno vpliva na zdravstveno stanje vojakov in povzroča resne težave živčnega sistema ter notranjih organov. O tem, kako nevarna sta aflatoksin in acetilholin, priča njuna uporaba $\mathrm{v}$ kmetijstvu ${ }^{4}$ in $\mathrm{v}$ teroristične namene. Raziskava govori predvsem o ameriških vojakih, medtem ko podatki o obolelih iraških vojakih in civilistih niso bili vključeni, čeprav so bili prav tako izpostavljeni podobnim dejavnikom ogrožanja (Slovenski kemijski portal). Tako je ameriška znanstvenica Beatrice Alexandra Golomb s kalifornijske univerze ugotovila, da so ameriški vojni veterani dobili sindrom zalivske vojne zaradi uživanja kemičnih substanc, ki jih je predpisovala vojska. Oboleli so imeli te težave: kronično utrujenost, nespečnost, depresijo, motnje v spominu in slabo psihično stanje. Znanstvenica se je seznanila $\mathrm{z}$ vojnimi veterani in proučila več vrst sindroma zalivske vojne. Ugotovila je, da stres, ki so ga vojaki doživeli med vojno, ne more biti vzrok za nastanek take psihoze, saj je vojna trajala premalo časa. Prvi povzročitelj so tablete na bazi acetilholinskih receptorjev, ki so jih predpisovali vojakom za zaščito pred iraškim napadom s plini. Povečana koncentracija teh receptorjev v krvi naj bi povzročila razgradnjo acetilena - posebne esence v živčevju, ki uravnava delovanje živčevja (Golomb, 2008). V prvi zalivski vojni so se kot bojni strupi najpogosteje uporabljali aflatoksini, ki jih tudi povezujejo z nastankom sindroma zalivske vojne. V tem primeru so ameriški vojaki obolevali za rakom, predvsem rakom jeter, vendar pa dokazov o povezanosti ni. Irak je proizvedel 2390 litrov tega toksina, pri čemer naj bi ga 1580 litrov porabil za izdelavo sedmih bomb. Njihovo delovanje je bilo odvisno predvsem od koncentracije in izpostavljenosti toksinu (Slovenski kemijski portal). Kronično se lahko zastrupimo, kadar smo aflatoksinu izpostavljeni dlje časa, vendar v manjših količinah. Kaže se v povečanem in bolečem žolčniku, slabi imunski odpornosti in tudi slabši koagulaciji krvi, kronična izpostavljenost aflatoksinu pa lahko vodi do ciroze in raka jeter. Aflatoksin naj bi kot testno orožje v prvi zalivski vojni uporabljali tudi Iračani (Munda, 2012).

Oddelek za zadeve vojnih veteranov je proučeval povezavo med izpostavljenostjo toksinom in razvojem sindroma. Na živčni sistem vplivajo kemični bojni strupi, na primer mestinon, in nekatere vrste pesticidov, ki imajo podobne učinke. Vojaški uradniki so bili že pred začetkom prve zalivske vojne zaskrbljeni, da bo iraški režim uporabil kemična sredstva bolj očitno, kot je to storil v vojni z Iranom. V času vojskovanja naj bi se slišalo na tisoče alarmov, veterani pa so po vrnitvi domov poročali o neznanih simptomih. Vlada je zavračala očitke o možnosti, da je bilo kemično orožje sploh uporabljeno (Research Advisory Committee on Gulf War Veterans' Illnesses, 2004). Britanski vojaki so na bojišču uporabljali tako imenovane alarmne izvidniške sisteme (NAIAD). NAIAD je sistem za kemično in biološko detekcijo, ki je nameščen nekoliko proč od vojaške enote in se samodejno sproži, če zazna kakšno nezaželeno snov. Med namestitvijo vojakov so se ti detektorji sprožili ob različnih priložnostih - dim iz helikopterjev ali džipov in cigaretni dim, zato so vojaki nehali

Acetilholinski receptor je sestavni del nekaterih pesticidov, ki jih uporabljajo v kmetijstvu; pri tem naj bi kmetje, ki uporabljajo omenjene kemikalije, trpeli za boleznijo, ki je zelo podobna sindromu zalivske vojne (Golomb, 2008). 
uporabljati zaščitne maske. Veliko število alarmov je med prvo zalivsko vojno na vojake delovalo zavajajoče in jih niso jemali resno. 19. januarja 1991 so bile zaradi zračnega napada koalicijske sile izpostavljene majhnim (nesmrtonosnim) količinam kemično in biološko aktivnih snovi, ki so bile izpuščene v iraškem napadu z raketnimi konicami, raketami, topništvom in letalskim strelivom (Medical News).

Poznejša poročila veteranov so govorila o tem, da so vojaki oboleli po tem, ko so kot zaščito pred kemičnim napadom jemali tablete NAPP za preprečitev živčnih bolezni z aktivno sestavino mestinon (Research Advisory Committee on Gulf War Veterans' Illnesses, 2004). Do potrditve o izpostavljenosti kemičnim snovem je prišlo, ko so Američani uničili skladišče orožja v Khamisyahu v Iraku. Najprej so trdili, da je bilo orožje za kemično, biološko in jedrsko orožje uničeno pozneje, in sicer po vojni. Glede na vojaška poročila pa naj bi bilo 75 odstotkov tovarn in skladišč kemičnega orožja uničenih že med vojno. Ministrstvo za obrambo je pozneje poročalo, da je skladišče v Khamisyahu vsebovalo živčna agenta sarin in ciklosarin, kar je spodbudilo proučevanje o tem, koliko in kateri veterani so bili ogroženi. Po številnih prizadevanjih in proučevanjih je bilo izpostavljenih okoli 100.000 vojakov, vendar je težko reči, ali so te številke dokončne. Pojavilo se je vprašanje, ali lahko taka izpostavljenost vodi v bolezen. Kot majhen odmerek je definirana količina, ki ne povzroči očitnih znakov in simptomov v času izpostavljenosti. Testiranje na živalih pa je pokazalo, kako lahko izpostavljenost nizkemu odmerku sarina vpliva na kronične indikatorje, kot so nevrološke in imunološke poškodbe. Komite je glede na te raziskave zaključil, da je majhna količina sarina lahko vzrok za kronično težavo (Research Advisory Committee on Gulf War Veterans' Illnesses, 2004).

\section{Strelivo z osiromašenim uranom}

Strelivo z osiromašenim uranom so razvili v 70. letih 20. stoletja na Zahodu kot odgovor na nevarnost z Vzhoda oziroma iz Sovjetske zveze. Tako strelivo je bilo prvič uporabljeno v prvi zalivski vojni. Osiromašen uran je stranski proizvod pri proizvodnji obogatenega urana za jedrsko orožje in goriva za jedrske reaktorje ter je 1,7-krat težji od svinca. Obogateni uran je v primerjavi z volframom bolj dosegljiv, cenejši, ima veliko gostoto in je vnetljiv v zraku. Ne uporabljajo ga zaradi njegove radioaktivnosti, temveč velike gostote, saj imajo takšni izstrelki zelo veliko kinetično energijo in prebojnost. Strelivo s penetratorji osiromašenega urana so Američani prvič uporabili v zalivski vojni leta 1991 proti iraškim oklepnikom. Orožje se je izkazalo za učinkovito, vendar je njegova uporaba vplivala na zdravje vojakov. Povečalo se je število rakavih obolenj tako med vojaki kot med iraškim civilnim prebivalstvom. Ob tem so se pojavila vprašanja o tem, ali so bolj nevarni ostanki streliva z osiromašenim uranom - povečana radiacija, ki se pojavi v okolici vozila po zadetku in po nekaj dneh izgine - ali staljeni ostanki oklepov tankov in oklepnikov ter staljena notranjost, ki je iz umetnih mas. Večina objavljenih raziskav kaže, da ni povezave med osiromašenim uranom in rakom; nekaj raziskav je dostopnih, vendar necelovitih, nekatere so označene kot vojaška skrivnost. Levkemija, ki je posledica povečane radioaktivnosti, se pojavi po več letih (petih); mogoče jo je odkriti s pregledom krvi in kostnega mozga (Bertell, 1994). 
Dr. Asaf Durakovic je uporabo osiromašenega urana v prvi zalivski vojni ocenil na 320 ton. Uran je bil uporabljen v plašču oklepa kot zaščita pred izstrelki. Ko je eksplozivno sredstvo zadelo plašč, se je ta razpočil na veliko delčkov, ki so postali del atmosfere. Vojaki so vdihavali onesnažen zrak, delci so ostali v njihovih pljučih, kar bi lahko povzročilo raka. Nekateri delci so vstopili v krvni sistem in prizadeli jetra in kosti. Neodvisni testi so pokazali visoko raven urana v urinu vojakov. Kljub številnim neodvisnim študijam in raziskavam sta ameriška in britanska vlada zanikali obstoj sindroma in sta izvajali svoje študije (CNN News, 2000).

Iraško ministrstvo za človekove pravice je sprožilo tožbo proti Veliki Britaniji in ZDA zaradi uporabe bomb z osiromašenim uranom. Tožbo in zahtevek za odškodnino naj bi sprožili na podlagi ugotovitev in poročil iraškega ministrstva za znanost in okolje. Vojaški strokovnjaki v Iraku so ocenili, da je bilo v bombnih napadih uporabljenih okoli 2000 ton osiromašenega urana. Zaradi sevanja se je povečalo število deformiranih otrok in rakavih obolenj (Hunter, 2010).

Pri otrocih britanskih vojakov, ki so se bojevali v zalivski vojni, v kateri je bilo uporabljeno strelivo z osiromašenim uranom, so raziskave pokazale, da se je število različnih razvojnih nepravilnosti otrok povečalo za približno 50 odstotkov v primerjavi z otroki, katerih očetje ali matere niso prišli v stik z osiromašenim uranom oziroma niso bili udeleženi v vojskovanju v Perzijskem zalivu. Vojakom, ki so bili izpostavljeni osiromašenemu uranu, so predlagali terapijo odstranjevanja težkih kovin iz telesa (Research Advisory Committee on Gulf War Veterans' Illnesses, 2004).

\section{Cepljenje proti antraksu}

Med operacijo Puščavski vihar je bilo proti antraksu cepljenih 41 odstotkov ameriških in 57 odstotkov britanskih vojakov. Cepivo je povzročilo hude lokalne reakcije na koži, ki so trajale več tednov in mesecev. Čeprav je Agencija za hrano in zdravila (FDA) cepivo odobrila, zanj niso bile nikoli opravljene klinične preiskave. Zaradi vbrizgavanja cepiva je bilo v letih od 1998 do 2000 hospitaliziranih 20.000 vojakov (BBC News, 2004). Ocenjeno je bilo, da je mestinon prejelo 250.000 vojakov. Rezultati ugotovitev so posledica individualnih preiskav. Snov je bila nevarna, če je bil vojak izpostavljen visoki temperaturi oziroma odprtemu ognju ali insekticidom in pesticidom, saj se je tako povečala njena toksičnost. Vojakinje so z jemanjem mestinona vplivale na zdravstveno stanje pozneje rojenih otrok (Lundy, 1997).

Dr. Rima Laibow je odkril, da je v cepivu proti prašičji gripi focetria 9,75 mg skvalena, ki ga povezuje z nastankom obolenj, kot so težave imunskega sistema, paraliza, avtizem, alzheimerjeva bolezen in sindrom zalivske vojne. V ZDA so ga veliko let uporabljali skrivoma, ker oblasti niso nikoli dobile dovoljenja za njegovo uporabo. 60.000 ameriških vojakov je pristalo v bolnišnicah zaradi bolezni, zato je leta 2004 vrhovno ameriško sodišče prepovedalo obvezno cepljenje s temi cepivi. Dr. Rima je odkril, da ima cepivo proti prašičji gripi kar milijonkrat več skvalena kot eksperimentalno zdravilo ameriške vojske, ki je znano pod imenom cepivo A. To je $\mathrm{v}$ neskladju $\mathrm{z}$ ameriškimi zakoni in zdravstveno etiko, zato bi morale tako početje 
oblasti obsoditi (BBC News, 2004). S študijo, ki so jo objavili leta 2000 v reviji American Journal of Pathology, so ugotovili, da je en sam odmerek skvalena pri poskusnih živalih sprožil kronično vnetje sklepov, ki ga poznamo tudi kot revmatoidni artritis. Do zdaj so ta dodatek zelo redko uporabili in se je vedno pokazal kot zelo problematičen. Težave, ki jih še zdaj imajo tisti, ki so dobili cepivo s tem dodatkom, so zelo številne - od artritisa, fibromalgije, občutljivosti na svetlobo, kronične utrujenosti, izgube spomina, multiple skleroze, težav s ščitnico, kronične driske, nočnega potenja do nenehno povišane temperature itn. (Carlson in drugi, 2000).

Vojaki, ki so bili udeleženi v prvi zalivski vojni, so prejeli netestirana Novartisova cepiva proti antraksu, v katerih je bil skvalen. Kar pri 30 odstotkih vseh vojakov so se razvile netipične avtoimunske bolezni (sindrom zalivske vojne), kar nekateri strokovnjaki povezujejo prav s skvalenom in cepljenjem. Tudi pri enotah, ki nikoli niso bile v Perzijskem zalivu, a so bile pozneje cepljene, so namreč opazili podobne simptome bolezni. Od vseh vojakov, ki so prejeli cepivo med letoma 1998 in 2000, jih je bilo 20.000 hospitaliziranih, vendar pa Pentagon ni nikoli seznanil kongresa s temi številkami (Blaylock, 2009).

Kljub sporazumom med FDA in ministrstvom za obrambo o prostovoljnem cepljenju je veliko veteranov povedalo, da niso vedeli, kaj so jim dali v cepiva ter kakšna so tveganja in posledice. Medicinsko osebje ni poročalo in vodilo zdravstvenih evidenc o težavah in bolečinah, ki so jih vojaki utrpeli s cepljenjem. Veterani menijo, da so bili s cepivom oškodovani (Miller, 1996).

O posledicah jemanja »zdravil« obstajajo pričevanja številnih udeleženih vojakov v prvi zalivski vojni. Nekateri so se tudi javno izpostavili, da bi dokazali obstoj bolezni in opozorili na resne zdravstvene težave. Drugi so zahtevali odškodnino za nastale težave in predčasno upokojitev ter status vojnega veterana. 52-letni Richard Turnbull, vojni veteran, je imel težave $\mathrm{z}$ dihanjem in bolečinami v prsnem košu, izgubo spomina in koncentracije in dovzetnostjo za kancerogene tumorje. Povedal je, da so vojaki v roku desetih minut prejeli tablete proti kugi, antraksu in malariji ter tablete za živce. Vzeli so jih zaradi nevarnosti pred iraškim kemičnim in biološkim orožjem (BBC News, 2011).

\section{Nalezljive bolezni}

Mešanice pesticidov, repelentov proti insektom in cepiv proti kemičnemu orožju so dokazano povzročile hude živčne motnje pri veteranih prve zalivske vojne. Poskusi na živalih so pokazali, da lahko pride do hudih živčnih motenj in izjemno povečane agresivnosti. Kazale so se težave pri razvoju živčevja (učinek na hormone ščitnice, povečana občutljivost za okoljski stres), motnje spomina (kratkotrajni spomin, težave z zbranostjo pri učenju itn.) in motorične motnje (neusklajena motorika rok in oči). Prizadet je bil imunski sistem in ovirano delovanje spolnih žlez (Nicolson in drugi, 1991). Znano je, da je bila uporabljena velika količina DDT-ja, malationa, fenitrotiona, propoksurja, deltametrina in permetrina, ki so živčni toksični povzročitelji in mnogi med njimi povzročajo raka in mutacije (Bertell, 1994). 
Sindrom zalivske vojne pa lahko razložimo tudi s kroničnimi patogenimi bakterijskimi okužbami, na primer z mikroplazmo, ki je najmanjši prost živ organizem. Ima visoko stopnjo neobčutljivosti na antibiotike. Mikroplazma povzroča okužbo dihal, širi pa se prek stika s kapljicami iz nosu ali žrela okuženih ljudi, še posebno, kadar kašljajo ali kihajo. Značilni simptomi so vročina, kašelj, bronhitis, vnetje grla, glavobol in utrujenost; skupni rezultat okužbe je pljučnica. V študiji je sodelovalo 2000 ameriških in britanskih vojakov, pri 40 odstotkih so bili potrjeni znaki okužbe (Research and Advisory Committee on Gulf War Veterans' Illnesses 2004). Okužbe z bakterijami so bile najdene pri veteranih in njihovih družinah, ki so imeli podobne simptome. Senat ZDA je pri proučevanju 1200 družin ugotovil, da je okoli 77 odstotkov partnerjev in 65 odstotkov rojenih otrok imelo simptome in znake sindroma zalivske vojne (Bertell, 1994).

Kronične bakterijske okužbe so lahko zdravili z antibiotiki ali s hiperbarično kisikovo terapijo, pri kateri se vdihuje 100-odstotni kisik v prostoru pod pritiskom. Uporablja se za zdravljenje resnih okužb ter mehurčkov zraka v žilah in ran, ki so posledica sladkorne bolezni ali poškodbe sevanja. Pri nekaterih se je pojavila nenormalno visoka stopnja določenih snovi - hormona aldosterona in kortizola ter vitamina B12 (Research Advisory Committee on Gulf War Veterans' Illnesses 2004). Leta 1993 je ameriška vlada sklicala razpravo zaradi zdravstvenih težav veteranov zalivske vojne in oblikovala seznam strokovnjakov, pristojnih za proučevanje problematike. Vojni veterani so samoiniciativno organizirali konferenco, na kateri so predstavili vzroke in načine zdravljenja bolezni. Strokovnjaki so ugotovili, da simptomi in znaki vojnih veteranov nimajo psihološkega izvora. Veteranom, pri katerih so odkrili prisotnost bakterij v urinu, so dali antibiotike. Veliko agresivnih patogenskih okužb je bilo uspešno pozdravljenih $\mathrm{z}$ antibiotikom doksiciklin. Inkubacijska doba (od meseca do več let) je bila odvisna od izpostavljenosti vojakov in se je kazala v obliki vročine in bolezni, ki so jih povzročili biološki agensi (Nicolson in drugi, 1991).

Najnovejše raziskave razkrivajo presenetljiva dognanja o toksičnih učinkih nitratov skupaj s pesticidi na nevroendokrini sistem, imunski sistem in človekovo vedenje. Najvidnejša posledica je vsesplošen upad odpornosti proti vsem okužbam in zunanjemu stresu. Dokazana je neposredna in posredna povezava s poškodbami imunskega sistema. Lahko gre za motene fiziološke povezave hipotalamus-hipofiza-ščitnica-nadledvična žleza (kortikosteroidni hormoni), pri drugi pa za neposreden vpliv na genezo in učinkovitost limfocitov B in T. Prav tako je prizadet tako imenovani defenzivni encimski sistem, ki deluje pri razstrupljanju organizma in ima torej bistveno vlogo pri obrambi proti kemičnemu stresu (Špogar, 2002).

Sklep Termin sindrom zalivske vojne se nanaša na množico različnih simptomov, ki so se začeli postopno pojavljati pri vojakih po koncu služenja v Perzijskem zalivu leta 1991. Težko je opredeliti samo enega povzročitelja, saj so bili vojaki med prvo zalivsko vojno izpostavljeni več različnim dejavnikom tveganja. Razvoj sindroma je glede na različne študije povezan $\mathrm{z}$ uporabo kemičnega orožja, streliva $\mathrm{z}$ osiromašenim 
uranom, cepljenjem proti antraksu ali z nalezljivimi boleznimi. Za različne oblike pojavljanja sindroma zalivske vojne je tudi težko opredeliti en sam način zdravljenja.

Prva država, ki je priznala sindrom zalivske vojne, je bila Velika Britanija leta 2002. Njegov obstoj so postopno priznale tudi druge države, predvsem zaradi povečanja števila obolelih vojakov. V ZDA so sindrom zalivske vojne priznali kot bolezen leta 2008, potem ko je opravila raziskave posebna komisija. Njegovemu priznanju so se izogibali predvsem zato, ker so se bali morebitnih zahtevkov za odškodnino, brezplačno zdravljenje (invalidnina, socialna pomoč in dolgotrajna nega na domu) in predhodno upokojitev - kar bi državam povzročilo ogromne stroške. Nekdaj »namišljen« pojav je postal še kako resnična in resna težava.

Sindrom zalivske vojne je pri veteranih še vedno prisoten, čeprav je od prve zalivske vojne minilo že več kot 20 let. Obstaja množica študij, raziskav in analiz različnih organizacij, inštitutov in zdravstvenih ustanov, ki se ukvarjajo z njenimi posledicami za zdravje. Pomembno je, da se o sindromu zalivske vojne v družbi kritično razpravlja, da se bomo v prihodnje izognili podobnim posledicam. Veterani si še vedno prizadevajo za svoje pravice in prek različnih društev ter organizacij za veterane $\mathrm{z}$ osebnimi izpovedmi seznanjajo druge.

1. BBC News, 2004. Gulf war veterans blames vaccines. http://news.bbc.co. uk/2/hi/ health/3906865.stm (19. julij 2012).

2. BBC News, 2011. Hull hospital pioneers Gulf War Syndrome treatment. http://www.bbc. co.uk/news/uk-england-humber-14685953 (26. avgust 2012).

3. Bertell, R., 1994. Gulf War Syndrome, Depleted Uranium and the Dangers of Low-Level Radiation. http://www.ccnr.org/bertell_book.html (21. april 2012).

4. Blaylock, R., 2009. Ne cepite se! http://ateistek.wordpress.com (12. april 2012).

5. Carslon, B., Jansson, A. M., Larson, A., Bucht, A., in Lorentzen, J. C., 2000. The Endogenous Adjuvant Squalene Can Induce a Chronic T-Cell-Mediated Arthritis in Rats. http://www.ncbi.nlm.nih.gov/pmc/articles/PMC185 0095/(22. februar 2012).

6. Clodfelter, M., 2002. Warfare and armed conflicts: a statistical reference to casualty and other figures. New York: McFarland \& Co.

7. CNN News, 2000. Gulf War soldiers may have »inhaled uranium«. http://archives.cnn. com/2000/WORLD/europe/09/03/france.gulf/index.html (3. marec 2012).

8. Gabriel, R., 1991. Nema više heroja: Ludilo i psihijatrija u ratu. Zagreb: Alfa.

9. Globus, broj 376, 20. veljače 1998, str. 34-37. Vijetnamski sindrom na hrvatski način.

10. Golomb, B. A., 2008. Acetylcholinesterase inhibitors and Gulf War illnesses. Proc Nati Acad Sci USA (105): 4295-4300.

11. Gulf War Syndrome Research. http://www.immed.org (3. marec 2012).

12. Hunter, G., 2010. Iraq Planning to Sue U.S. and U.K. Over Depleted Uranium Munitions. http://usawatchdog.com/iraq-planning-to-sue-u-s-and-u-kover-depleted-uraniummunitions/ (10. februar 2012).

13. Hyams, K. C., Wignall, F. S., Roswell, R., 1996. War Syndromes and Their Evaluation: From U.S. Civil War to the Persian Gulf War (Review). Annals of Internal Medicine, 1 September 1996, 125, str. 398-405.

14. Lundy, P., 1997. Stress and the Production of CNS Effects of Pyridostigmine: A Commentary. http://www.asanltr.com/ASANews-97/Pyridostigmine.html (3. marec 2012). 
15. Medical News. What is Gulf War Syndrome? http://www.news-medical.net/health/What-isGulf-War-Syndrome.aspx (12. maj 2012).

16. Miller, Neil Z. 1996. Experimental Vaccines and Gulf War Syndrome. http://thinktwice. com/gulfwar.htm (2. marec 2012).

17. Munda, M., 2012. Aflatoksin: Zahrbtni strup v hrani. http://www.ekomagazin.si/Prehrana/ Prehrana/Aflatoksin.html (1. maj 2012).

18. Nicolson, L. G., Nasralla, M. Y., Haier, J., Erwin, R., Nicolson, N. L., in Ngwenya, R., 1991. Mycoplasmal Infections in Chronic Illnesses: Fibromyalgia and Chronic Fatigue Syndromes, Gulf War Illness, HIV-AIDS and Rheumatoid Arthritis. Medical Sentinel (4): $172-176$.

19. Research Advisory Committee on Gulf War Veterans' Illnesses, 2004. Scientific Progress in Understanding Gulf War Veterans' Illnesses: Report and Recommendations.

20. Slatenšek, B., 2002. Drugi puščavski vihar: Kakšen je bil prvi ameriški napad na Irak in po čem se bo od njega razlikoval drugi. Mladina 35, 3. november.

21. Slovenska tiskovna agencija, 2008. Zalivski sindrom je resnična bolezen. Delo.si, 18. november. http://www.delo.si/clanek/71154 (15. maj 2012).

22. Slovenski kemijski portal. Biološko orožje: Aflatoksin. http://www.kemija.org/index.php/ kemija-mainmenu-38/24-kemijacat/211-bioloko-oroje-aflatoksin (4. april 2012).

23. Špogar, U., 2002. Svareča dognanja znanstvenikov. Večer.com, 21. avgust 2002 (4. april 2012).

24. UCDP Conflict Encyclopedia. Uppsala University. 
Avtorji

Authors 


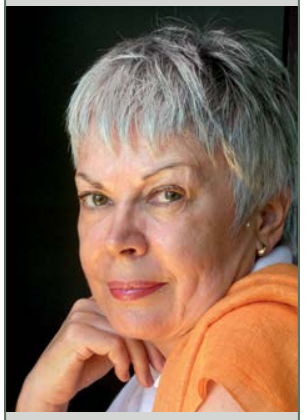

Nada Serajnik Sraka

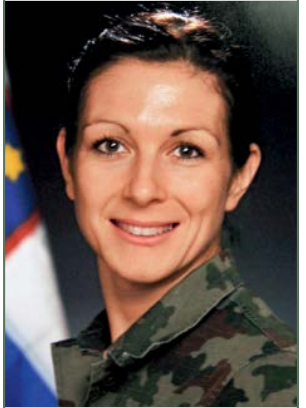

Nina Raduha
Mag. Nada Serajnik Sraka je izkušena profesionalna komunikatorka, ki že tri desetletja deluje na področju slovenskih odnosov z javnostmi. Zaposlena je bila v Uradu Vlade RS za komuniciranje in sodelovala $\mathrm{v}$ največjih slovenskih javnih komunikacijskih kampanjah. Je avtorica več člankov o odnosih z javnostmi, ustanovna članica Slovenskega društva za odnose z javnostmi (PRSS) in slovenske sekcije IABC; bila je tudi njuna predsednica. Leta 2009 je izšla njena knjiga Komunikacijske kampanje - priročnik za načrtovanje, vodenje in ocenjevanje kampanj.

Nada Serajnik Sraka, MSc, is an experienced professional communicator and has been engaged in Slovenia's public relations for three decades. She has worked at Communication Office of the Government of the Republic of Slovenia and participated in major Slovenian public communication campaigns. She authored several articles on public relations and is a founding member of the Public Relations Society of Slovenia and Slovenian section of IABC. She also acted as president of both. In 2009, she published her book 'Komunikacijske kampanje - priročnik za načrtovanje, vodenje in ocenjevanje kampanj' (Communication campaigns - Handbook for campaign planning, management and evaluation).

Stotnica Nina Raduha je univerzitetna diplomirana politologinja, smer obramboslovje. V Slovenski vojski je zaposlena od leta 2003. Sodelovala je v mirovni operaciji v BiH. Bila je častnica za odnose z javnostmi 1. brigade SV, odgovorna urednica glasila Prvi in monografije 1. brigade SV. Leta 2011 je uspešno končala štabno šolanje in prevzela poveljevanje minometne čete v 20. motoriziranem bataljonu. Na šoli za obrambno komuniciranje v ZDA je z odliko zaključila priznani tečaj s področja odnosov z javnostmi.

Captain Nina Raduha holds a BA degree in Political Sciences - Defence Studies. She has worked in the Slovenian Armed Forces (SAF) since 2003. She participated in the peace operation in Bosnia-Herzegovina and worked as Public Affairs Officer in the SAF $1^{\text {st }}$ Brigade. She was engaged as Managing Editor with the Prvi bulletin and the $1^{\text {st }}$ Brigade monograph. In 2011, she completed a staff course and became commander of Morter Company/20 $0^{\text {th }}$ Motorised Battalion. She is Distinguished Honor Graduate of the U.S. Defense Information School. 


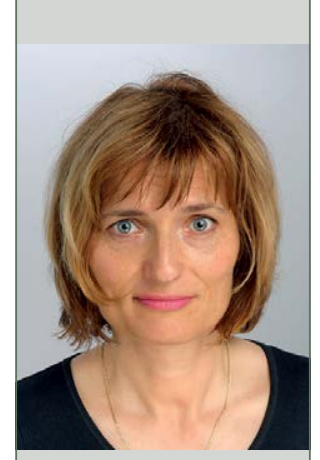

Liliana Brožič

Doc. dr. Liliana Brožič je diplomirala na Fakulteti za organizacijske vede, smer organizacija, magistrirala na Fakulteti za družbene vede po mednarodnem programu MESPA (Master Degree in European Social Policy Analysis) in doktorirala na Fakulteti za državne in evropske študije s temo Izobraževalni sistem kot funkcija razvoja vojaške znanosti. Od leta 1996 je zaposlena na Ministrstvu za obrambo. Od leta 2010 je podsekretarka za publicistiko v Sektorju za odnose z javnostmi v Slovenski vojski.

Assist. Prof. Liliana Brožič, PhD graduated from the Faculty of Organisational Sciences (Organisation studies). She obtained a Master's Degree in European Social Policy Analysis (MESPA) at the Faculty of Social Sciences and PhD at the Faculty of State and European Studies with the thesis entitled Education system as a function of military science development. She has worked at the Ministry of Defence since 1996. Since 2010, she has been working as Undersecretary for Publications in the Public Affairs Division of the Slovenian Armed Forces.

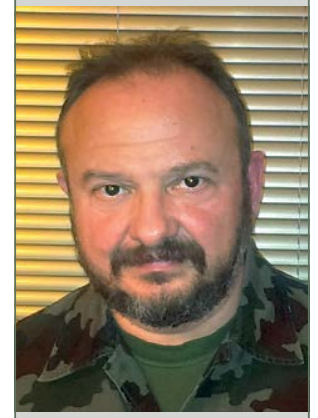

Višji vojaški uslužbenec XII. razreda Miran Barovič je diplomiral iz psihologije leta 1988 na Filozofski fakulteti v Ljubljani. V Slovenski vojski se je zaposlil leta 1992 v 410. učnem centru v Postojni in nato služboval v različnih poveljstvih in enotah SV, trenutno pa je pripadnik Logistične brigade. Leta 1996 je končal šolo za častnike. Štirikrat je bil $\mathrm{v}$ mednarodnih operacijah in na misijah (Kosovo, Bosna in Hercegovina).

\section{Senior Military Specialist Class XII, Miran Barovič} graduated in psychology from the Faculty of Arts, Ljubljana in 1988. He joined the Slovenian Armed Forces (SAF) in 1992 as member of the $410^{\text {th }}$ Training Centre in Postojna. Later he worked in different SAF commands and units and is currently employed in the SAF Logistic Brigade. In 1996, he completed Officer Candidate School. He was deployed to international missions and operations four times (Kosovo, Bosnia-Herzegovina). 


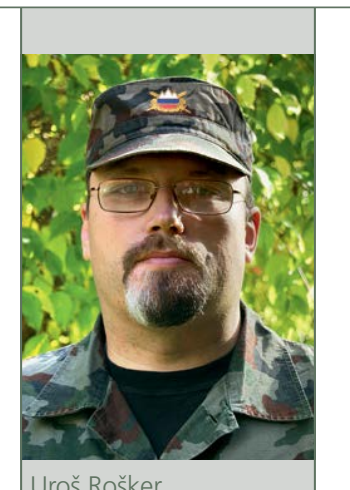

Višji vojaški uslužbenec IX. razreda Uroš Rošker je leta 2007 diplomiral na Oddelku za psihologijo na Filozofski fakulteti v Ljubljani. Leta 2008 se je zaposlil v Slovenski vojski na dolžnosti v oddelku za klinično psihološko dejavnost v Vojaški zdravstveni enoti SV in kot enotovni psiholog v 1. vrigadi SV. Sodeloval je na dveh misijah Slovenske vojske na Kosovu. Trenutno opravlja dolžnost psihologa v Logistični brigadi SV.

\section{Senior Military Specialist Class IX, Uroš Rošker} graduated in psychology from the Faculty of Arts, Ljubljana in 2007. He joined the Slovenian Armed Forces (SAF) in 2008, where he worked in the Section for Clinical Psychology of the SAF Medical Unit and as and embedded psychologist with SAF $1^{\text {st }}$ Brigade. He has been deployed to Kosovo twice. Currently, he works as psychologist in the SAF Logistic Brigade.

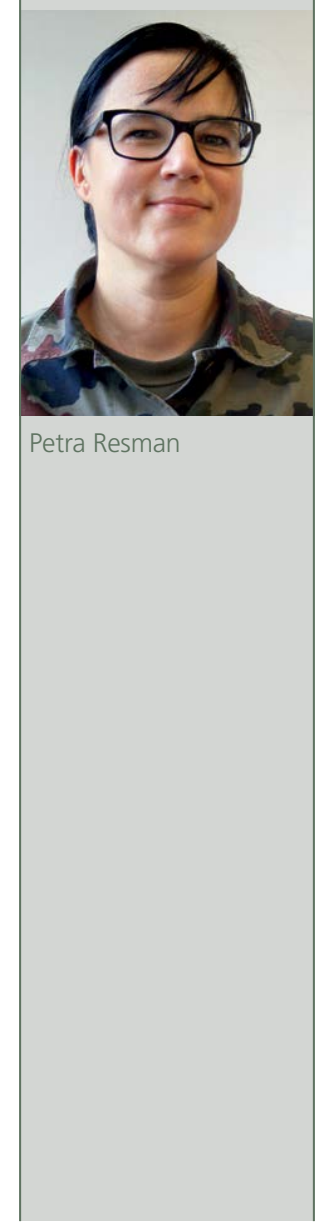

Višja vojaška uslužbenka XII. razreda Petra Resman je leta 1997 diplomirala na Filozofski fakulteti iz psihologije. V SV se je zaposlila leta 2000, pred tem je delala v sociali in šolstvu. Kot psihologinja je delala $\mathrm{v}$ pehotnem bataljonu in pozneje več let $\mathrm{v}$ oddelku za psihološko dejavnost na Poveljstvu sil. V tem času se je dejavno vključevala $\mathrm{v}$ aktivnosti mednarodnega in civilno-vojaškega sodelovanja na področju stroke. Je avtorica nekaj strokovnih člankov in soavtorica več prispevkov na mednarodnih simpozijih vojaške psihologije.

Senior Military Specialist, Class XII, Petra Resman graduated in psychology from the Faculty of Arts, Ljubljana in 1997. She joined the Slovenian Armed Forces (SAF) in 2000 after being employed in social care and school system. She worked as psychologist with an infantry battalion and for several following years in the Psychology Operations Section of the SAF Force Command. During this time, she was actively engaged in subject-matter activities within international and civil-military cooperation. She authored few professional articles and co-authored several contributions at international military psychology symposia. 


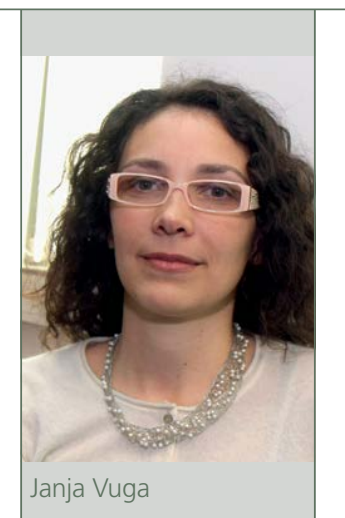

Doc. dr. Janja Vuga s Katedre za obramboslovje na Fakulteti za družbene vede Univerze $\mathrm{v}$ Ljubljani predava predmet mirovne operacije in sodeluje pri predmetih sociologija in politologija vojske ter informatika za obramboslovce. Njeno raziskovalno delo obsega proučevanje medkulturnih odnosov in drugih socioloških dejavnikov v mednarodnih operacijah in na misijah ter delovanje civilnih funkcionalnih strokovnjakov, analizo usklajevanja zasebnega življenja oziroma družine in službe v vojaški organizaciji, vlogo spola v vojaški organizaciji ter analizo stališč javnosti do varnostnih vprašanj.

Assist. Prof. Janja Vuga, PhD works at the Chair of Defence Studies of the Faculty of Social Sciences, University of Ljubljana, where she holds lectures on peace operations and participates in the subjects of Sociology and political science of the military and Informatics for Defence Studies students. Her research work focuses on the studies of intercultural relations and other sociological factors in international operations and missions as well as on the functioning of civil functional experts, analysis of the coordination of work and family life in a military organisation, the role of gender in a military organisation and the analysis of public opinion regarding security issues.

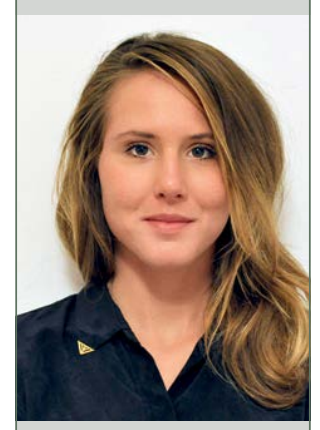

Katarina Rajh je študentka Fakultete za družbene vede in trenutno v Lizboni končuje dodiplomski študij mednarodnih odnosov. V času študija se je ukvarjala s humanitarnim vidikom mirovnih operacij in vlogo nevladnih organizacij $\mathrm{v}$ MOM. K članku je prispevala svoje poznavanje oblik podpore vojaškim družinam in pripadnikom/-cam, ki jih poznajo $\mathrm{v}$ tujini.

Katarina Rajh is a student of the Faculty of Social Sciences and is currently completing her undergraduate studies in International Relations in Lisbon. During her studies, she dealt with humanitarian perspective of international operations and the role of non-governmental organisations in international operations and missions. In the article, she contributed her knowledge on the forms of support provided to military families and servicemembers in foreign countries. 


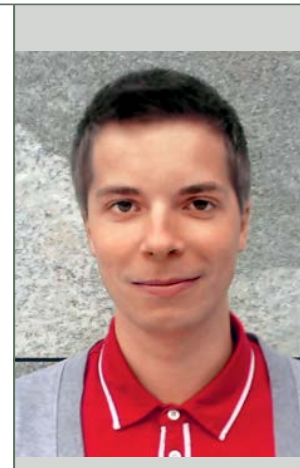 \\ Gašper Kavšek \\ Gašper Kavšek končuje študij mednarodnih odnosov na Fakulteti za družbene vede. V času študija se je aktivno ukvarjal z vlogo OZN pri zagotavljanju mednarodnega miru in varnosti. Za potrebe članka je analiziral intervjuje s slovenski- mi vojaškimi družinami, pri čemer se je osredotočil predvsem na njihove demografske značilnosti. \\ Gašper Kavšek is completing his International Relations studies at the Faculty of Social Sciences. During his studies, he actively dealt with the role of the UN in the provision of in- ternational peace and security. In the article, he analysed the interviews with Slovenian military families, focusing mainly on their demographic characteristics.}

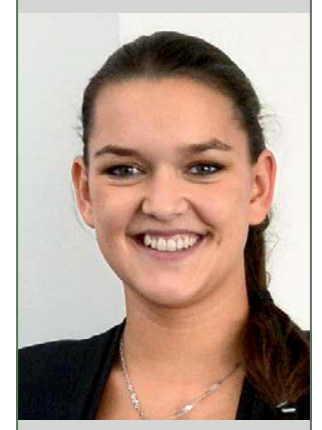

Katja Cimermančič končuje študij mednarodnih odnosov na Fakulteti za družbene vede. V času študija je izkazala zanimanje za proučevanje delovanja mednarodnih in regionalnih organizacij. Aktivno sodeluje v Evro-atlantskem svetu Slovenije in pri vsakoletni organizaciji mednarodnih simulacij OZN (SiMUN). Za članek je analizirala intervjuje s slovenskimi vojaškimi družinami.

Katja Cimermančič is completing her International Relations studies at the Faculty of Social Sciences. During her studies, she has been demonstrating special interest in the functioning of international and regional organisations. She expresses her interest through active engagement in the EuroAtlantic Council of Slovenia and annual organisation of UN simulations (SiMUN). In the article, she analysed interviews with Slovenian military families.

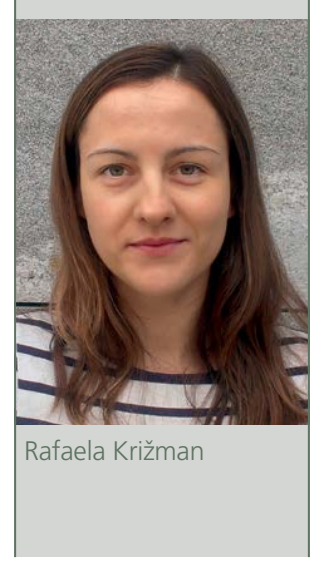

Rafaela Križman končuje študij mednarodnih odnosov na Fakulteti za družbene vede. V času študija je pokazala zanimanje za mednarodno diplomacijo. Opravljala tudi prakso na Veleposlaništvu RS v Sarajevu. V članku se je ukvarjala z analizo intervjujev vojaških družin.

Rafaela Križman is completing her International Relations studies at the Faculty of Social Sciences. During her studies, she has been demonstrating special interest in international diplomacy and interned at the Embassy of the Republic of Slovenia in Sarajevo. In the article, she analysed interviews with military families. 


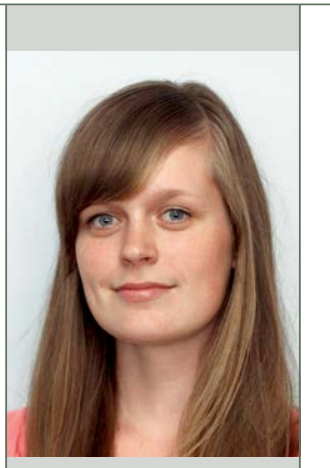

Urška Učakar

Urška Učakar je diplomantka mednarodnih odnosov in magistrska študentka na Fakulteti za družbene vede. Trenutno opravlja prakso na sedežu OZN v New Yorku. Njeno glavno interesno področje so mirovne operacije. Pri pisanju članka je sodelovala $\mathrm{z}$ analizo konflikta med plačanim delom in zasebnim življenjem in družino.

Urška Učakar graduated in International Relations and is a master's degree student at the Faculty of Social Sciences of the University of Ljubljana. Currently, she is interning at UN Headquarters in New York. Her main field of interest includes peace operations. In the article, she dealt with the analysis of conflict between paid work and private life/family.

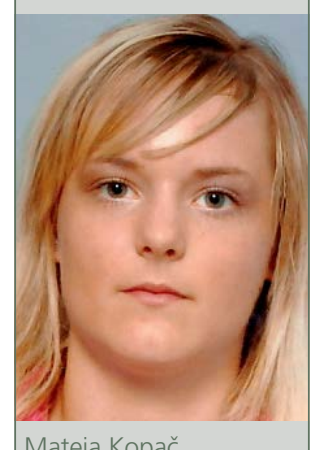

Mateja Kopač je univerzitetna diplomirana politologinja, smer obramboslovje. Leta 2012 je zagovarjala diplomsko delo z naslovom Sindrom zalivske vojne (1990-1991). Strokovno prakso je opravljala na Mestni občini Ljubljana, Odbor za zaščito, reševanje in civilno obrambo. Trenutno je študentka magistrskega študija obramboslovja na Fakulteti za družbene vede, njeno proučevanje pa se osredotoča na sodobne vojaške in varnostne izzive.

Mateja Kopač holds a BA degree in Political Sciences Defence Studies. In 2012, she defended her BA thesis entitled "Gulf War Syndrome (1990 - 1991)". She completed her internship at the Municipality of Ljubljana, Committee on Civil Protection and Disaster Relief. She is currently a master's degree student in Defence Studies at the Faculty of Social Sciences and her studies concentrate on contemporary military and security challenges. 


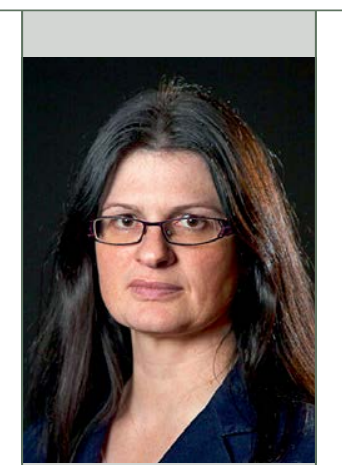

Doc. dr. Maja Garb je doktorirala na področju obramboslovja in je docentka na Fakulteti za družbene vede. Ukvarja se s sociološkim proučevanjem vojaške organizacije in reševanja konfliktov (analiza sodobnih konfliktov, mirovne operacije ter pokonfliktna obnova). Delovne zahteve so jo usmerile tudi v proučevanje vodenja in menedžmenta $\mathrm{v}$ vojski in obrambnem sistemu.

Assist. Prof. Maja Garb, PhD, holds a PhD in Defence Studies and is Assistant Professor at the Faculty of Social Sciences, University of Ljubljana. She deals with sociological aspects of military organisation and resolution of conflicts (analysis of modern conflicts, peace operations and post-conflict reconstruction). Working requirements led her to conduct research in management and governance in the armed forces and the defence system.

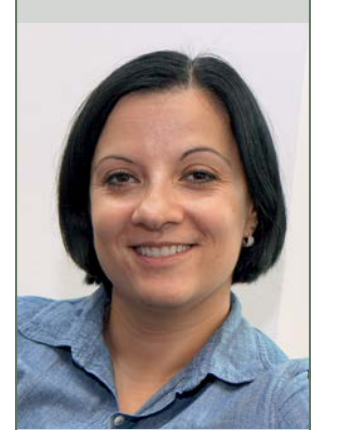

Asist. dr. Jelena Juvan je univerzitetna diplomirana politologinja in doktorica znanosti s področja obramboslovja. Kot raziskovalka je od leta 2003 zaposlena na Obramboslovnem raziskovalnem centru Fakultete za družbene vede. Leta 2008 je doktorirala s temo Vojaške družine: usklajevanje delovnih in družinskih obveznosti v vojaški organizaciji. Sodeluje v pedagoškem procesu na Fakulteti za družbene vede pri predmetih polemologija, sociologija in politologija vojske ter skupna zunanja in varnostna politika Evropske unije.

Assist. Jelena Juvan, PhD, holds a degree and PhD in DefenceStudies. She has worked as researcher at the Defence Research Centre of the Faculty of Social Sciences since 2003. In 2008, she obtained her PhD with theses entitled Military Families: Coordinating Work and Family Obligations in a Military Organisation. She participates in the teaching process at the Faculty of Social Sciences: Polemology, Sociology and Political Science of Armed Forces and Common Foreign and Security Policy of the EU. 


\section{Navodila avtorjem za oblikovanje prispevkov Instructions for the authors of papers}




\section{NAVODILA AVTORJEM ZA OBLIKOVANJE PRISPEVKOV ZA SODOBNE VOJAŠKE IZZIVE IN VOJAŠKOŠOLSKI ZBORNIK}

\section{Vsebinska navodila}

Splošno Sodobni vojaški izzivi je interdisciplinarna znanstveno-strokovna publikacija, ki objavlja prispevke o aktualnih temah, raziskavah, znanstvenih in strokovnih razpravah, tehničnih ali družboslovnih analizah z varnostnega, obrambnega in vojaškega področja.

Vojaškošolski zbornik je vojaškostrokovna in informativna publikacija, namenjena izobraževanju in obveščanju o dosežkih ter izkušnjah na področju vojaškega izobraževanja, usposabljanja in izpopolnjevanja.

Kaj objavljamo?

Objavljamo prispevke v slovenskem jeziku s povzetki, prevedenimi v angleški jezik, in po odločitvi uredniškega odbora prispevke v angleškem jeziku s povzetki, prevedenimi v slovenski jezik.

Objavljamo prispevke, ki še niso bili objavljeni ali poslani v objavo drugi reviji. Pisec je odgovoren za vse morebitne kršitve avtorskih pravic. Če je bil prispevek že natisnjen drugje, poslan v objavo ali predstavljen na strokovni konferenci, naj to avtor sporočiti uredniku in pridobiti soglasje založnika (če je treba) ter navesti razloge za ponovno objavo.

\section{Tehnična navodila}

Omejitve Prispevki naj obsegajo 16 strani oziroma 30.000 znakov s presledki (avtorska dolžine prispevkov pola), izjemoma najmanj 8 strani oziroma 15.000 znakov ali največ 24 strani oziroma 45.000 znakov.

Recenzije Prispevki se recenzirajo. Recenzija je anonimna. Glede na oceno recenzentov uredniški odbor ali urednik prispevek sprejme, če je treba, zahteva popravke ali ga zavrne. Pripombe recenzentov avtor vnese v prispevek.

Zaradi anonimnega recenzentskega postopka je treba prvo stran in vsebino oblikovati tako, da identiteta avtorja ni prepoznavna.

Avtor ob naslovu prispevka napiše, v katero kategorijo po njegovem mnenju in glede na klasifikacijo v COBISS spada njegov prispevek. Klasifikacija je dostopna na spletni strani revije in pri odgovornem uredniku. Končno klasifikacijo določi uredniški odbor.

Lektoriranje Lektoriranje besedil zagotavlja OE, pristojna za založniško dejavnost. Lektorirana besedila se avtorizirajo. 
Prevajanje Prevajanje besedil ali povzetkov zagotavlja OE, pristojna za prevajalsko dejavnost oziroma Šola za tuje jezike PDRIU.

Navajanje Navajanje avtorjev je skrajno zgoraj, levo poravnano.

avtorjev Primer:

prispevka Ime 1 Priimek 1 ,

Ime 2 Priimek 2

V opombi pod črto se za slovenske avtorje navede, iz katere ustanove prihajajo. Pri tujih avtorjih je treba navesti tudi ime države.

Naslov Navedbi avtorjev sledi naslov prispevka. Črke v naslovu so velike 16 pik, natiprispevka snjene krepko, besedilo naslova pa poravnano na sredini.

Povzetek Prispevku mora biti dodan povzetek, ki obsega največ 1200 znakov (20 vrstic). Povzetek naj na kratko opredeli temo prispevka, predvsem naj povzame rezultate in ugotovitve. Splošne ugotovitve in misli ne spadajo v povzetek, temveč v uvod.

Povzetek Avtorji morajo oddati tudi prevod povzetka v angleščino. Tudi za prevod povzetka v angleščini velja omejitev do 1200 znakov (20 vrstic).

Ključne

Ključne besede (3-5, tudi $\mathrm{v}$ angleškem jeziku) naj bodo natisnjene krepko in $\mathrm{z}$ besede obojestransko poravnavo besedila.

Besedilo Avtorji naj oddajo svoje prispevke na papirju formata A4, s presledkom med vrsticami 1,5 in velikostjo črk 12 pik Arial. Na zgornjem in spodnjem robu naj bo do besedila približno $3 \mathrm{~cm}$, levi rob naj bo širok $2 \mathrm{~cm}$, desni pa $4 \mathrm{~cm}$. Na vsaki strani je tako približno 30 vrstic s približno 62 znaki. Besedilo naj bo obojestransko poravnano, brez umikov na začetku odstavka.

Kratka Avtorji morajo pripraviti kratko predstavitev svojega strokovnega oziroma znanpredstavitev stvenega dela. Predstavitev naj ne presega 600 znakov (10 vrstic, 80 besed). Če avtorjev je avtorjev več, se predstavi vsak posebej, čim bolj zgoščeno. Avtorji naj besedilo umestijo na konec prispevka po navedeni literaturi.

Struktu- $\quad$ Posamezna poglavja v besedilu naj bodo ločena s samostojnimi podnaslovi in riranje besedila ustrezno oštevilčena (členitev največ na 4 ravni).

Primer:

1 Uvod

2 Naslov poglavja (1. raven)

2.1 Podnaslov (2. raven)

2.1.1 Podnaslov (3. raven)

2.1.1.1 Podnaslov (4. raven) 
Oblikovanje V seznamu literature je treba po abecednem redu navesti le avtorje, na katere seznama se sklicujete v prispevku, celotna oznaka vira pa mora biti skladna s harvardliterature skim načinom navajanja. Če je avtorjev več, navedemo vse, kot so navedeni na izvirnem delu.

Primeri:

a) knjiga:

Priimek, ime (lahko začetnica imena), letnica. Naslov dela. Kraj: Založba.

Na primer:Urlich, W., 1983. Critical Heuristics of Social Planning. Chicago: University of Chicago Press.

b) zbornik:

Samson, C., 1970. Problems of information studies in history. V S. Stone, ur. Humanities information research. Sheffield: CRUS, 1980, str./pp. 44-68. Pri posameznih člankih v zbornikih na koncu posameznega vira navedemo strani, na katerih je članek, na primer:

c) članek v reviji

Kolega, N., 2006. Slovenian coast sea flood risk. Acta geographica Slovenica. 46-2, str. $143-167$.

Navajanje Vse reference se začenjajo enako kot pri natisnjenih virih, le da običajnemu delu virov $\mathbf{z}$ interneta sledi še podatek o tem, kje na internetu je bil dokument dobljen in kdaj. Podatek o tem, kdaj je bil dokument dobljen, je pomemben zaradi pogostega spreminjanja www okolja.

Urlich, W., 1983. Critical Heuristics of Social Planning. Chicago: University of Chicago Press, str. 45-100. http://www.mors.si/index.php?id=213, 17. 10. 2008. Pri navajanju zanimivih internetnih naslovov v besedilu (ne gre za navajanje posebnega dokumenta) zadošča navedba naslova (http://www.vpvs.uni-lj.si). Posebna referenca na koncu besedila $\mathrm{v}$ tem primeru ni potrebna.

Sklicevanje Pri sklicevanju na vire med besedilom navedite le priimek prvega avtorja in na vire letnico izdaje. Primer: ... (Smith, 1997) ...

Če dobesedno navajate del besedila, ga ustrezno označite z narekovaji, v oklepaju pa poleg avtorja in letnice navedite stran besedila, iz katerega ste navajali.

Primer: ... (Smith, 1997, str. 15) ...

Pri povzemanju drugega avtorja napišemo besedilo brez narekovajev, v oklepaju pa napišemo, da gre za povzeto besedilo. Primer: (po Smith, 1997, str. 15). Če avtorja navajamo $\mathrm{v}$ besedilu, $\mathrm{v}$ oklepaju navedemo samo letnico izida in stran (1997, str. 15). 
Slike, diagrami in tabele
Opombe pod črto

Kratice

Format zapisa prispevka

Naslov avtorja

Kako poslati prispevek

Potrjevanje sprejetja prispevka
Slike, diagrami in tabele $\mathrm{v}$ prispevku naj bodo v posebej pripravljenih datotekah, ki omogočajo lektorske popravke. V besedilu mora biti jasno označeno mesto, kamor je treba vnesti sliko. Skupna dolžina prispevka ne sme preseči dane omejitve.

Če avtor iz tehničnih razlogov grafičnih dodatkov ne more oddati v elektronski obliki, je izjemoma sprejemljivo, da slike priloži besedilu. Avtor mora $\mathrm{v}$ tem primeru na zadnjo stran slike napisati zaporedno številko in naslov, $\mathrm{v}$ besedilu pa pustiti dovolj prostora zanjo. Prav tako mora biti besedilo opremljeno z naslovom in številčenjem slike. Diagrami se štejejo kot slike. Vse slike in tabele se številčijo. Številčenje poteka enotno in ni povezano s številčenjem poglavij. Naslov slike je naveden pod sliko, naslov tabele pa nad tabelo. Navadno je v besedilu navedeno vsaj eno sklicevanje na sliko ali tabelo. Sklic na sliko ali tabelo je: ... (slika 5) ... (tabela 2) ...

Primer slike: $\quad$ Primer tabele:

Tabela 2: Naslov tabele

Slika 5: Naslov slike

Številčenje opomb pod črto je neodvisno od strukture besedila in se v vsakem prispevku začne s številko 1. Posebej opozarjamo avtorje, da so opombe pod črto namenjene pojasnjevanju misli, zapisanih v besedilu, in ne navajanju literature.

Kratice naj bodo dodane v oklepaju, ko se okrajšana beseda prvič uporabi, zato posebnih seznamov kratic ne dodajamo. Za kratico ali izraz v angleškem jeziku napišemo najprej slovensko ustreznico, v oklepaju pa angleški izvirnik in morebitno angleško kratico.

Uredniški odbor sprejema prispevke, napisane z urejevalnikom besedil MS Word, izjemoma tudi v besedilnem zapisu (text only).

Prispevkom naj bosta dodana avtorjeva naslov in internetni naslov ali telefonska številka, na katerih bo dosegljiv uredniškemu odboru.

Na naslov uredništva ali članov uredniškega odbora je treba poslati tiskano in elektronsko različico prispevka.

Uredniški odbor avtorju pisno potrdi prejetje prispevka. Avtorjem, ki sporočijo tudi naslov svoje elektronske pošte, se potrditev pošlje po tej poti. 
Korekture Avtor opravi korekture svojega prispevka v treh dneh.

Naslov Ministrstvo za obrambo

uredniškega Generalštab Slovenske vojske

odbora Sodobni vojaški izzivi

Uredniški odbor

Vojkova cesta 55

1000 Ljubljana

Slovenija

Elektronski naslov

Odgovorna urednica:

liliana.brozic@mors.si

Prispevkov, ki ne bodo urejeni skladno s tem navodilom, uredniški odbor ne bo sprejemal. 


\section{INSTRUCTIONS FOR THE AUTHORS OF PAPERS FOR THE CONTEMPORARY MILITARY CHALLENGES AND THE MILITARY EDUCATION JOURNAL}

\section{Content-related instructions}

General The Contemporary Military Challenges is an interdisciplinary scientific expert magazine, which publishes papers on current topics, researches, scientific and expert discussions, technical or social sciences analysis from the field of security, defence and the military..

The Military Education Journal is a military professional and informative publication intended for education and informing on achievements and experiences in the field of military education, training and improvement.

What do we publish?

We publish papers in Slovene with abstracts translated into English. If so decided by the Editorial Board, we also publish papers in English with abstracts translated into Slovene.

We publish papers, which have not been previously published or sent to another magazine for publication. The author is held responsible for all possible copyright violations. If the paper has already been printed elsewhere, sent for publication or presented at an expert conference, the author must notify the editor, obtain the publisher's consent (if necessary) and indicate the reasons for republishing.

\section{Technical instructions}

Limitations regarding the length of the papers
The papers should consist of 16 typewritten double-spaced pages or 30,000 characters. At a minimum they should have 8 pages or 15,000 characters and at a maximum 24 pages or 45,000 characters. 
Reviews All papers are reviewed. The review is anonymous. With regard to the reviewer's assessment, the Editorial Board or the editor accepts the paper, demands modifications, if necessary, or rejects it. Upon receiving the reviewers' remarks, the author inserts them into the paper.

Due to an anonymous review process, the first page must be designed in the way that the author's identity cannot be recognized.

Next to the title, the author should indicate the category the paper belongs to according to him and according to the classification in the COBISS ${ }^{1}$. The classification is available on the magazine's internet page and at the responsible editor. The Editorial Board determines the final classification.

Proofreading The organizational unit responsible for publishing provides the proofreading of the papers. The proofread papers have to be approved.

Translating The translation of the papers or abstracts is provided by the organizational unit competent for translation or the School of Foreign Languages, DDETC.

Indicating The authors' name should be written in the upper left corner, aligned left.

the authors Example:

of the paper Name 1 Surname 1,

Name 2 Surname 2,

In the footnote, Slovenian authors should indicate the institution they come from. Foreign authors should also indicate the name of the state they come from.

Title of the The title of the paper is written below the listed authors. The font in the title is paper bold, size 16 points. The text of the title is centrally aligned.

Abstract The paper should have an abstract of a maximum 1,200 characters (20 lines). The abstract should include a short presentation of the topic, particularly the results and the findings. General findings and reflections do not belong in the abstract, but rather in the introduction.

Abstract in The authors must also submit the translation of the abstract into English. The English translation of the abstract is likewise limited to a maximum of 1,200 characters (20 lines).

Key words Key words (3-5 also in the English language) should be bold with a justified text alignment.

Text

The authors should submit their papers on an A4 paper format, with 1.5 line spacing, fontArial size 12 points. At the upper and the bottom edge, there should be approx. $3 \mathrm{~cm}$ of space; the left margin should be $2 \mathrm{~cm}$ wide and the right margin $4 \mathrm{~cm}$. Each page consists of approx. 30 lines with 62 characters. The text should have a justified alignment, without indents at the beginning of the paragraphs. 
A brief pre- The authors should prepare a brief presentation of their expert or scientific work. sentation of The presentation should not exceed 600 characters (10 lines, 80 words). If there the authors are several authors, each should be presented individually, as shortly and as comprehensively as possible. These texts should be placed at the end of the paper, after the cited literature.

Text structuring

Individual chapters should be separated with independent subtitles and adequately numbered.

Example:

1 Introduction

2 Title of the chapter $\left(1^{\text {st }}\right.$ level $)$

2.1 Subtitle ( $2^{\text {nd }}$ level)

2.1.1 Subtitle $\left(3^{\text {rd }}\right.$ level $)$

2.1.1.1 Subtitle $\left(4^{\text {th }}\right.$ level $)$

Referencing In the bibliography, only the authors of references one refers to in the paper should be listed, in the alphabetical order. The entire reference has to be in compliance with the Harvard citing style.

Example:

Surname, name (can also be the initial of the name), year. Title of the work. Place. Publishing House.

\section{Example:}

Urlich, W., 1983. Critical Heuristics of Social Planning. Chicago: University of Chicago Press.

With certain papers published in journals, the author should indicate, at the end of each reference, a page on which the paper can be found.

\section{Example:}

Urlich, W., 1983. Critical Heuristics of Social Planning. Chicago: University of Chicago Press. p. 45-100.

Referencing All references start the same as the references for the printed sources, only that internet the usual part is followed by the information about the Internet page on which the document was found as well as the date on which it was found. The information about the time that the document was found on the Internet is important, because the WWW environment changes constantly.

Urlich, W., 1983. Critical Heuristics of Social Planning. Chicago: University of Chicago Press. p. 45-100. http://www.mors.si/index.php?id=213, 17 October 2008.

When referencing interesting WWW pages in the text (not citing an individual document) it is enough to state only the Internet address (http://www.vpvs.uni-lj. si). A separate reference at the end of the text is therefore not necessary. 
Citing

Figures, diagrams, tables

Footnotes

Abbreviations

Format type of the paper
When citing sources in the text, indicate only the surname of the author and the year of publication. Example: ..... (Smith, 1997) ...

When making a direct reference to a text, the cited part should be adequately marked with quotation marks and followed by the exact page of the text which the citing is taken from.

Example: ...(Smith, 1997, p.15) ...

Figures, diagrams and tables in the paper should be prepared in separate files which allow for proofreading corrections. The place in the text where the picture should be inserted must be clearly indicated. The total length of the paper must not surpass the given limitation.

Should the author not be able to submit the graphical supplements in the electronic form due to technical reasons, it is exceptionally acceptable to enclose the figures to the text. In this case the author must write a sequence number and a title on the back of each picture and leave enough space in the text to include it. The text must likewise contain the title and the sequence number of the figure. Diagrams are considered figures.

All figures and tables are numbered. The numbering is not uniform and not linked with the numbering of the chapters. The title of the figure is stated beneath it and the title of the table is stated above it.

As a rule, the paper should include at least one reference to a figure or a table.. Reference to a figure or a table is: ... (Figure 5) (Table 2) .........

Example of a figure: $\quad$ Example of a table:

Table 2: Title of the table

Figure 5: Title of the figure

The numbering of the footnotes is not related to the structure of the text and starts with number 1 in each paper. We want to stress that the aim of the footnotes is to explain the thoughts written in the text and not to reference literature.

When used for the first time, the abbreviations in the text must be explained in parenthesis; therefore no additional list of abbreviations is needed. If the abbreviations or terms are written in English, the appropriate Slovenian term should be written along with the English original and possibly the English abbreviation in the parenthesis.

The Editorial Board accepts only the texts written with a MS Word text editor and only exceptionally those in the 'text only' format. 
Author's Each paper should include the author's address, e-mail or a telephone number, so address that the Editorial Board can reach him or her.

Sending A print or an electronic version of the paper should be sent to the address of the the paper Editorial Board or the members of the Editorial Board.

Confirma- The Editorial Board sends the author a written confirmation regarding the tion of the reception of the paper. The authors who also list their e-mails receive the confirreception of mation via e-mail.

the paper

Corrections The author makes corrections to the paper within three days.

$\begin{array}{ll}\text { Editorial } & \text { Ministry of Defence } \\ \text { Board } & \text { Slovenian Armed Forces } \\ \text { address } & \text { General Staff } \\ & \text { Contemporary Military Challenges } \\ & \text { Editorial Board } \\ & \text { Vojkova cesta 55 } \\ & \text { 1000 Ljubljana } \\ & \text { Slovenia } \\ & \text { Electronic address: } \\ & \text { Editor in Chief: } \\ & \text { liliana.brozic@mors.si }\end{array}$

The Editorial Board will not accept papers, which will not be in compliance with the above instructions. 

Sodobni vojaški izzivi - 15/št. 2

Vsebina

Liliana Brožič

UVODNIK

EDITORIAL

Nada Serajnik Sraka

KOMPLEKSNOST OBRAMBNO-VOJAŠKEGA OKOLA NAREKUJE STRATEŠKO UPRAVLANJE ODNOSOV Z JAVNOSTMI

THE COMPLEXITY OF DEFENCE AND MILITARY ENVIRONMENT REQUIRES STRATEGIC PUBLIC RELATIONS MANAGEMENT

Nina Raduha

DRUŽBENA OMREŽJA KOT IZZIV KOMUNICIRANJA V SLOVENSKI VOJSKI SOCIAL NETWORKS AS A CHALLENGE OF COMMUNICATION IN THE SLOVENIAN ARMED FORCES

Liliana Brožič

EVALVACIJA ODNOSOV Z JAVNOSTMI V SLOVENSKI VOJSKI EVALUATION OF SLOVENIAN ARMED FORCES PUBLIC AFFAIRS

Miran Barovič Uroš Rošker

Petra Resman

Janja Vuga,

Katarina Rajh,

Gašper Kavšek,

VOJSKA Z VIDIKA TEMELNIH POJMOV SOCIALNE PSIHOLOGIJE MILITARY FROM THE POINT OF VIEW OF BASIC SOCIAL PSYCHOLOGY TERMS

Katja Cimermančič, PSIHOLOŠKO DELOVANJE - VOJAŠKO DELOVANJE ALI UPORABNA SOCIALNA PSIHOLOGIJA?

PSYCHOLOGICAL OPERATIONS - MILITARY OPERATIONS OR APPLICABLE SOCIAL PSYCHOLOGY?

Rafaela Križman,

Urška Učakar

Mateja Kopač, Jelena Juvan, Maja Garb

SOCIALNA, INSTITUCIONALNA IN ORGANIZACIJSKA PODPORA V POHLEPNIH INSTITUCIJAH: ZADOVOLSTVO SLOVENSKIH VOJAŠKIH DRUŽIN SOCIAL, INSTITUTIONAL AND ORGANISATIONAL SUPPORT IN GREEDY INSTITUTIONS: SATISFACTION OF SLOVENIAN MILITARY FAMILIES

SINDROM ZALIVSKE VOJNE GULF WAR SYNDROME 